Resistance of winter cereals to various winter stress factors inter- and intraspecific variation and the role of cold acclimation

\author{
LEENA MAARIT HÖMMÖ \\ Agricultural Research Centre of Finland \\ Institute of Crop and Soil Science \\ Plant Breeding Section \\ FIN-31600 Jokioinen, Finland
}


"You believe snow is cold, but if you build yourself a snowhouse it's warm. You think it's white, but at times it looks pink, and another time it's blue. It can be softer than anything, and then again harder than stone. Nothing is certain."

Tove Jansson in

'Moominland midwinter'

To Reino,

Mikko, Riikka and Reetta 


\section{LIST OF ORIGINAL ARTICLES}

This thesis is based on the following original papers referred to in the text by their Roman numerals. Additional data are also presented.

I Höмmö, L. \& PULli, S. 1993. Winterhardiness of some winter wheat (Triticum aestivum), rye (Secale cereale), triticale (X Triticosecale) and winter barley (Hordeum vulgare) cultivars tested at six locations in Finland. Agricultural Science in Finland 2: 311-327.

II Hӧммӧ, L. M. 1992. Hardening ability of some winter wheat, winter rye and winter barley varieties. Use of conductivity method in evaluating the hardening ability of overwintering crop species. Norwegian Journal of Agricultural Science 7 (Suppl.): 39-50.

III Нӧммӧ, L. M. 1993. Hardening of some winter wheat (Triticum aestivum L.), rye (Secale cereale L.), triticale (X Triticosecale Wittmack) and winter barley (Hordeum vulgare L.) cultivars during autumn and the final winter survival in Finland. Plant Breeding (in press).

IV Нӧммӧ, L. 1993. Accumulation of dry matter and sugar and changes in plasma membrane fatty acids in two winter wheat (Triticum aestivum L.) cultivars with different winterhardiness abilities. (Submitted.)

V Hömmö, L., HannukKala, A. \& PUlli, S. 1992. Screening for resistance of winter wheat and rye varieties to Finnish snow mould (Microdochium nivale) isolates. Hodowla Róslin Aklimatyzacja i Nasiennictwo 37 (Special issue Nr. 2): 133-139.

VI HöмmÖ, L. M. 1993. Screening winter rye cultivars for snow mould (Microdochium nivale) resistance. Plant Pathology (in press).

VII НӧммÖ, L. 1993. Effect of hardening and dehardening on snow mould (Microdochium nivale) resistance of winter wheat. (Submitted.) 


\section{CONTENTS}

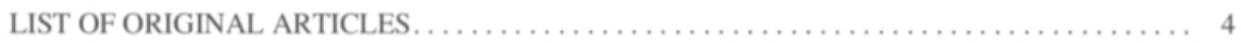

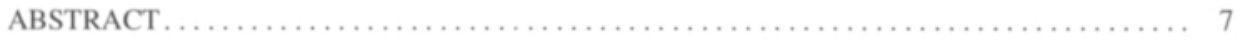

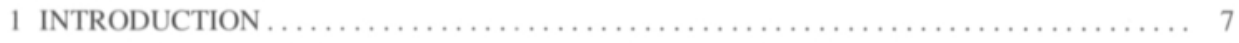

1.1 Cold tolerance of plants and seasonal changes in frost resistance $\ldots \ldots \ldots \ldots \ldots \ldots \ldots \ldots$

1.2 Environmental factors related to cold acclimation $\ldots \ldots \ldots \ldots \ldots \ldots \ldots \ldots \ldots \ldots \ldots .9$

1.3 Physiological and biochemical changes during cold acclimation. $\ldots \ldots \ldots \ldots \ldots \ldots \ldots$

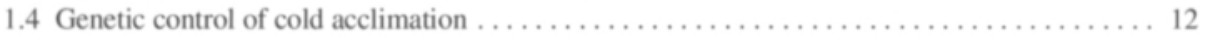

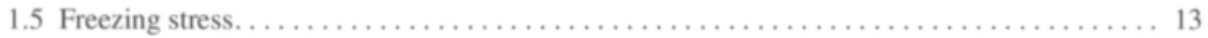

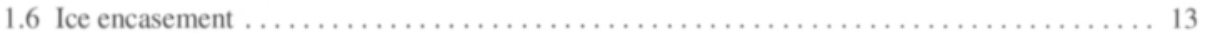

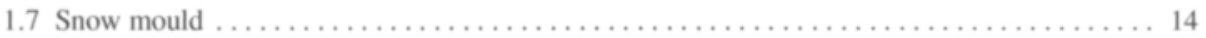

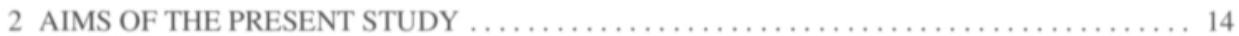

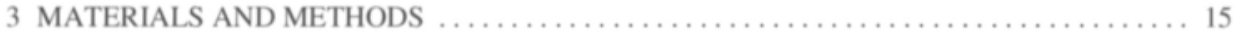

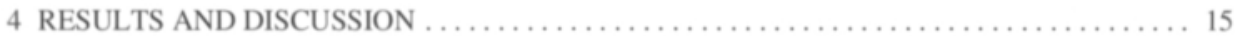

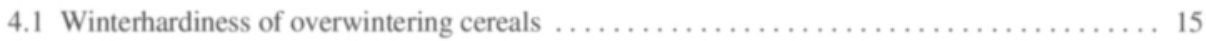

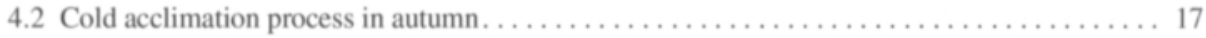

4.3 Changes in plasma membranes during cold acclimation $\ldots \ldots \ldots \ldots \ldots \ldots \ldots \ldots \ldots \ldots 18$

4.4 Changes in cell constituents during cold acclimation. $\ldots \ldots \ldots \ldots \ldots \ldots \ldots \ldots \ldots \ldots \ldots 19$

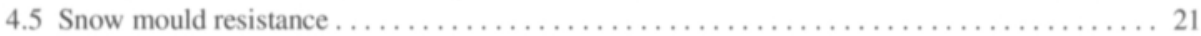

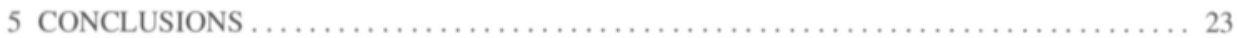

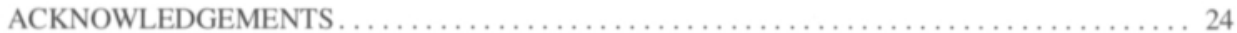

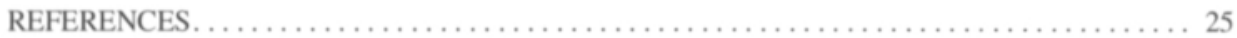

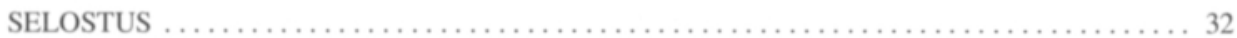




\title{
Resistance of winter cereals to various winter stress factors - inter- and intraspecific variation and the role of cold acclimation
}

\author{
LEENA MAARIT HÖMMÖ
}

\begin{abstract}
Номмо, L. M. 1994. Resistance of winter cereals to various winter stress factors inter- and intraspecific variation and the role of cold acclimation. Agricultural Science in Finland 3: Supplement No. 1. 32 p. Academic dissertation. (Agricultural Research Centre of Finland, Institute of Crop and Soil Science, Plant Breeding Section, FIN-31600 Jokioinen, Finland.)
\end{abstract}

This work was undertaken to study the inter and intraspecies variation in winterhardiness of overwintering cereal species and to find out the reasons for this variation.

The studied 24 winter wheat (Triticum aestivum L.), 13 rye (Secale cereale L.), 5 triticale ( $X$ Triticosecale Wittmack) and 11 barley (Hordeum vulgare L.) cultivars differed highly significantly from each other in winter survival ability determined in field trials during 1989-1992 at six locations in Finland and at altogether 17 locations in all the Nordic countries. The Field Survival Indexes of cultivars were determined, too. Rye was the most winter hardy species followed by winter wheat, triticale and barley. Since field trials often fail to screen the resistance of plants to specific winter stress factors, such as frost or snow mould, laboratory tests were used to study these factors.

On the basis of the results it could be concluded that, during cold acclimation, sugars and proline are accumulated, and the fatty acid composition of the plasma membrane lipid fractions is changed. Cold acclimation enhances frost resistance and general winterhardiness of overwintering cereals, but part of the snow mould (Microdochium nivale (Fries) Samuels \& Hallet) resistance may be induced without low temperature treatment. Thus, different resistance mechanisms may be controlling frost and snow mould resistance.

The results of this study suggest that general winterhardiness of overwintering species could be enhanced by screening separately resistance mechanisms of plants to various specific winter stress factors and combining these into new cultivars.

Key words: frost resistance, hardening, Microdochium nivale, rye, snow mould resistance, triticale, winter barley, winterhardiness, winter wheat

\section{INTRODUCTION}

\subsection{Cold tolerance of plants and seasonal changes in frost resistance}

In the course of evolution, plants have adapted to grow and reproduce under different environmental stresses, either abiotic (e.g. drought and temperat- ure extremes) or biotic (e.g. competition of weeds, pathogens, pests). Changes in environmental conditions create new strains in plants resulting in adaptation of populations to new conditions (new fitness) by differentiation of new ecotypes or species. The prerequisite for adaptation is that genetic vari- 
ation exists in the base population available for natural selection.

According to SAKAI and LARCHER (1987), adaptation of plants to low temperatures has proceeded in three steps. First, plants became resistant to chilling temperatures $\left(0^{\circ} \mathrm{C}-15^{\circ} \mathrm{C}\right)$ by lowering the critical phase transition temperature of their biomembranes. Second, the freezing resistance of plants was improved by adjusting the osmotic value of the cell sap, increasing the plasma membrane cryostability, and by improving the supercooling capacity. The third step in cold adaptation involved increased dehydration tolerance of cells necessary for resistance to equilibrium freezing. The first two steps might have occurred in the border regions or highlands of tropics, and the third step in regions with a dry season. Thus adaptation in regions with cold winters involved both the timing of growth to the frost free period, and an increased freezing resistance of plants.

However, only a relatively small number of plant species have evolved tolerance to freezing. Plant species of tropical and subtropical origin are most often chilling sensitive, with no resistance to chilling or freezing temperatures. Many important crops, such as rice, maize, soybean and cotton, fall into this category (LEVITT 1980, WILSON 1987). To survive occasional frosts, some of these species are able to avoid freezing by supercooling.

In temperate and alpine regions, plants are generally chilling resistant, but their freezing resistance varies depending on the severity of the climate they are adapted to and on their life form. Thus plant species or plant organs exposed to severe frosts without protective snow cover are the most hardy ones. This group includes trees and shrubs, which in a fully hardened state (many species are dormant) can tolerate temperatures down to $-50^{\circ} \mathrm{C}$, and the hardiest species even treatment with liquid nitrogen (GUSTA 1985).

Overwintering herbaceous plants are usually protected against the temperature extremes by snow cover. These plants acclimate to cold during autumn and they overwinter as green plants without true dormancy. This group includes overwintering grasses, e.g. agronomically important forage grasses and winter cereals, and the temperature limit for their survival is usually $-30^{\circ} \mathrm{C}$ (GUSTA 1985).

Annual herbs overwinter as seeds, but some of them tolerate moderate freezing temperatures (spring cereals tolerate temperatures down to $-8^{\circ} \mathrm{C}$ and summer turnip rape down to $-5^{\circ} \mathrm{C}$ ) during the active growth period (GUSTA 1985).

Resistance to freezing temperatures is a very important factor in determining the distribution of species, since an annual minimum temperature below $0^{\circ} \mathrm{C}$ is typical of about 64 percent of the earth's land area (GROUT 1987). The freezing tolerance of plants is, however, not static, but varies seasonally or in response to environmental changes that signal the onset of the low temperature season. Even the most winter hardy species are frost sensitive during the active growth phase. Thus Picea abies and many Salix species (CHRISTERSSON 1985 ) are injured already at $-3^{\circ} \mathrm{C}$ and winter cereals at about $-10^{\circ} \mathrm{C}$ (GuSTA 1985) in July. The change from a frost sensitive to a frost resistant state occurs during autumn, and is called low temperature (cold) acclimation or hardening.

Cold acclimation proceeds in stages, resulting in increased frost hardiness. Woody plants from temperate and especially from the northern zones develop bud dormancy in autumn to survive the temperature extremes. Contrary to woody perennials, herbaceous plants do not develop a true dormancy during late summer; their growth potential is maintained throughout the winter period (SAKAI and LARCHER 1987).

KACPERSKA-PALACZ (1978) and KACPERSKA (1989) found three stages in the hardening of winter rape. The first stage is induced by lowering the temperature to $+5^{\circ} \mathrm{C}-2^{\circ} \mathrm{C}$. During this stage the growth rate is reduced, plants adjust their metabolism to cold conditions, and the freezing resistance increases a few degrees above the initial level. KACPERSKA (1989) divided this first stage into two phases: 1 . the reaction phase, when the cellular metabolism is disturbed by the sudden drop in temperature, and 2. the restitution or reconstruction phase, when the new metabolic equilibrium is created, and new metabolites (sugars, proteins, amino acids, lipids, nucleic acids) are formed. The second stage of cold acclimation is induced by subfreezing 
temperatures $\left(-1^{\circ} \mathrm{C}-0^{\circ} \mathrm{C}\right)$ and it could be considered the stage of real frost tolerance development. The maximal freezing resistance of herbage plants is achieved during prolonged frosts. This third stage of cold acclimation may overlap the second one.

The freezing resistance of plants is not static throughout the winter period, but varies according to the fluctuation in ambient temperature. Freezing resistance is decreased when plants are subjected to temperatures above $0^{\circ} \mathrm{C}$ during thaw periods in winter. The ability of a plant to reharden after dehardening during the thaw depends on the timing of thaw, in late spring plants being unable to reharden (FOWLER and GUSTA 1977). It also depends on the genotype of plants, more winter hardy cultivars reacting less to changes in temperature (EAGLES and Williams 1992, Fedulov et al. 1990, GuSTA and FOWLER 1976a, 1976b, POMEROY et al. 1975). BoLDUC et al. (1988) observed that foxtail barley (Hordeum jubatum L.) and winter rye (Secale cereale $\mathrm{L}$.) cultivars were able to reharden even after five dehardening cycles, while the hardening ability of winter wheat (Triticum aestivum L.) and triticale (X Triticosecale Wittmack) cultivars decreased already after the third dehardening cycle. Thus the winter survival of plants is not only dependent on their hardening ability, but also on their ability to maintain a high level of frost hardiness during prolonged incubation at low temperatures, and on their ability to reharden after thaw periods.

In natural conditions the frost resistance of winter wheat cultivars was decreased in Canada and in Hungary already in late December (ANDREWS et al. 1974, VEISZ and RAJKI 1987). The dehardening of cloudberry (Rubus chamaemorus L.) started in February in Norway (JUNTTILA and KAURIN 1989), and the dehardening of Norway spruce (Picea abies L) and Scots pine (Pinus sylvestris L.) increased after mid-April in Finland (REPO 1992).

\subsection{Environmental factors related to cold acclimation}

Temperature is the most important single factor determining the seasonal changes in and the level of the frost resistance of plants. Both the frost harden- ing of plants in autumn and their dehardening during winter thaws are induced mainly by the changes in ambient temperature.

In woody plants light is an important factor determining the annual cycle of growth and dormancy. HÄNNINEN et al. (1990) found the model based on the night length to be the most efficient in determining the growth cessation of woody plants. Photoperiod is also involved in the cold acclimation of herbaceous plants, and usually prolonged night connected to the low temperature induces the hardening (GRIFFITH and MCINTYRE 1990, JUNTTILA et al. 1990, STEPONKUS 1978). According to GRIFFITH and MCINTYRE (1993), cold acclimation of winter rye is induced only by low temperature, but the level of frost resistance is dependent upon both the amount of light, which affects the amount of photoassimilate synthesis, and the photoperiod, which may affect the partitioning of photoassimilates between growth and frost tolerance.

The first stage of cold acclimation of herbaceous plants proceeds only in light (KACPERSKA 1985, LEVITT 1980). If cold acclimation is carried out in shortage of light or in darkness, the frost resistance of plants is not enhanced in spite of the cold temperature (BARTA and HODGES 1970, SJÖSETH 1964). Sprouting wheat was, however, found to be able to cold acclimate in darkness, with the aid of energy reserves in the seed endosperm (ANDREWS 1960). Photosynthesis provides the energy needed in the cold acclimation process, and high levels of carbohydrates are accumulated during the first stage of hardening. According to BARTA and HODGES (1970), the rate of photosynthesis during cold acclimation correlates positively with the winterhardiness of wheat cultivars. However, at low temperatures the ability of the plant to process and utilize the captured light energy is reduced, resulting in an overproduction of trapped light energy. This excess of energy may be injurious to the photosynthetic apparatus, resulting in photoinhibition. Cold acclimation increased resistance to photoinhibition in rye (HURRY et al. 1993a, 1993b, ÖQUIST and HUNER 1993) and potato (STEFFEN and PALTA 1989). HUNER et al. (1989) and HURRY et al. (1993b) also reported that winter wheat cultivars developed a greater resistance to photoinhibition 
during cold acclimation than did the spring wheat cultivars. Spring barley was unable to develop any significant resistance to photoinhibition. Thus, the ability to resist photoinhibition during the low temperature acclimation, to ensure the net positive photosynthesis, is important in the development of frost resistance of plants.

Conflicting reports exist on the role of soil moisture content in hardening. TYLER et al. (1981) and Willemot and PeLletier (1979) observed that drought stress prior to or during cold acclimation, enhanced frost resistance of winter wheat cultivars. Similar results were obtained by CLOUTIER and ANDREWS (1984) in winter wheat and rye seedlings, but not in oats and barley. LARSEN (1978) suggested that restricted soil moisture towards the end of the growth period and during hardening results in increased frost resistance. On the other hand, ClOuTIER et al. (1990) found that the moderate to high soil moisture content during hardening resulted in the best freezing resistance in winter cereals.

In spite of the soil moisture content, the tissue water content, however, generally decreases during cold acclimation in overwintering plants (GUSTA et al. 1982, KACPERSKA 1993). METCALF et al. (1970) reported that freezing resistance of winter wheat and barley plants is highly dependent on the crown moisture content and, according to GUSTA and FOWLER (1976a), frost survival and crown moisture content are positively correlated during dehardening and rehardening of winter wheat and rye.

The addition of nitrogen to plants prior to cold acclimation has been found to decrease frost hardiness of winter cereals, while the applied phosphorus and potassium generally enhance the overwintering ability (FOWLER and GUSTA 1982, GUSTA 1986, GUSTA et al. 1982, HETHERINGTON et al. 1990, TYLER et al. 1981).

\subsection{Physiological and biochemical changes during cold acclimation}

During the period of cold acclimation, changes in the environmental conditions affect several aspects of the development and metabolism of plants, and frost hardening is only one of these processes. Thus it is understandable that some of the numerous metabolic changes that take place during the cold acclimation period adjust plants to grow at low temperatures and are not connected to the freezing tolerance of plants.

Increased dry matter content is usually connected to the enhanced freezing resistance of plants (DÖRFFling et al. 1990, HUNER et al. 1989, KETELEER et al. 1988, LEVITT 1980). The increase in dry matter content results from both a decrease in cell water content and an increase in cytoplasmic constituents (HUNER et al. 1989). Compounds that accumulate during cold acclimation include soluble sugars (e.g. sucrose, raffinose), sugar alcohols (e.g. sorbitol), amino acids (e.g. proline), quaternary amines (e.g. betaine) and polyamines (KACPERSKAPALACZ 1978, LeVITT 1980, RøSNES et al. 1993, SAKAI and LARCHER 1987). These compounds may enhance the freezing resistance either by increasing the osmotic value of the cell sap, resulting in a lowering of the freezing point and a possible avoidance of freeze-induced cell dehydration (LEVITT 1980 ), or by acting as cryoprotectants, thus protecting the biomembranes against freeze desiccation (ANCHORDOGUY et al. 1987, CROWE et al. 1990, LiNEBERGER and STEPONKUS 1980, SANTARIUS and GIERSCH 1983).

The induction of freezing and chilling tolerance requires a sensory mechanism for detecting environmental signals. Several environmental factors, e.g. drought, salt stress, anaerobic conditions and temperature extremes, are known to affect the endogenous level of abscisic acid (ABA) in plant tissues (CAPELl and DörfFling 1989). Endogenous ABA levels increase during cold acclimation in several woody and herbaceous plants (LEVITT 1980, SAKAI and LARCHER 1987). LEE and CHEN (1993) presented four lines of evidence indicating that $\mathrm{ABA}$ is involved in the induction of cold hardiness: 1. ABA levels rise during cold acclimation in woody and perennial plants. 2. Exogenously applied ABA has been reported to induce frost hardiness at non-acclimating temperatures (DÖRFFLING et al. 1989, LÅNG et al. 1989, REANEY and GUSTA 1987). 3. ABA treatment induces frost resistance only in species that are able to cold acclimate 
(CHEN and GUSTA 1983). 4. Plants undergo similar physiological and morphological changes during ABA induced hardening and cold acclimation (LALK and DöRFFLING 1985).

$\mathrm{ABA}$ is suggested to be involved in the regulation of protein synthesis during cold acclimation by affecting the gene expression (CHEN and GUSTA 1983, LeE and CHEN 1993, Li et al. 1989, PALTA and Weiss 1993, RoBERTSON et al. 1993). However, a number of studies indicate that several of the novel polypeptides are synthesized during cold acclimation independently of the endogenous ABA (DHINDSA et al. 1993, GROSSI et al. 1992, NORDIN et al. 1993, TномASHOw et al. 1993). This would imply that cold regulated gene expression might occur also independently of ABA action.

Cellular membranes, particularly the plasma membrane, were proposed to be the primary sites of freezing injury already about 80 years ago (MAXIMOV 1912). Since then, numerous studies have supported this view (HUNER et al. 1989, LEVITT 1980, PALTA and Weiss 1993, SingH and LAROCHE 1988, STEPONKUS 1984, STEPONKUS and LYNCH 1989). During equilibrium freezing water diffuses out of the cells to form extracellular ice, resulting in protoplasmic dehydration and cell shrinkage (LEVITT 1980). During the thaw, cells rehydrate and re-expand. Plasma membranes must maintain their semipermeability during the freeze-thaw cycle if the cells are to survive both the efflux and the influx of water. Thus, lysis or alterations in the semipermeable characteristics (e.g. phase transitions) of the plasma membrane are a primary cause of freezing injury (STEPONKUS et al. 1990).

Both protein and lipid composition of the membranes have been found to change during cold acclimation (STEPONKUS 1984, STEPONKUS and LYNCH 1989). UEMURA and YosHIDA (1984) and YOSHIDA and UEMURA (1984), working on winter rye and orchard grass (Dactylis glomerata L.), observed distinct changes in protein composition in purified plasma membrane preparations during cold acclimation. A number of polypeptides decreased and disappeared while new polypeptides were synthesized during acclimation. The phospholipid:protein ratios were also higher in plasma membranes of cold acclimated than in non-accli- mated plants. Although UEMURA and YoshIDA (1984) and YosHIDA and UEMURA (1984) suggested that cold acclimation results in only modest changes in the lipid composition of the plasma membrane, LYNCH and STEPONKUS (1987) found changes in the proportions of virtually every lipid component. The amounts of free sterols and phospholipids increased and the levels of diunsaturated fatty acids of phospholipids doubled in cold acclimated cells. STEPONKUS et al. (1988) were also able to enhance the freezing resistance of non-acclimated rye protoplasts by elevating the levels of unsaturation of plasma membrane phospholipids. However, freezing resistance increased only at temperatures above $-10^{\circ} \mathrm{C}$, indicating that freezing tolerance of plasma membranes involves multiple alterations, each having different effects. PALTA and WEISS (1993) reported that the changes in membrane lipid composition during cold acclimation differed in acclimating and non-acclimating potato species. Increased linoleic acid (18:2) and decreased palmitic acid (16:0) contents in the plasma membrane lipids were observed only in acclimating potato species. These changes occurred simultaneously with the increase in freezing tolerance and ATPase activity, indicating that the membrane fluidity has an influence on the function of the membrane proteins.

PALTA and WeISs (1993) concluded that changes in the concentrations of $\mathrm{ABA}$ induce the synthesis of new proteins or change the function of some others. This, in turn, brings about changes in the plasma membrane lipid and protein composition (ATPase), resulting in enhanced freezing resistance.

PALTA et al. (1977a, 1977b) reported that in onion bulb cells the ion and sugar transport mechanisms of plasma membrane were freeze injured before the semipermeable properties of the membrane were damaged and when the cells were still microscopically uninjured. They found also that potassium ions were the main ions that leaked out from injured cells, but the amount of leaked calcium ions increased also according to the severity of the treatment. PALTA and LI (1980) observed that the transport properties of membrane proteins were more vulnerable to freezing than those associated 
with membrane lipids. On the basis of these results it was hypothesized that the incipient freezing injury was due to perturbation in the function of the plasma membrane $\mathrm{H}^{+}$-ATPase (ISWARI and PALTA 1989, PAltA 1989, 1992, PALTA and Weiss 1993). The central role of $\mathrm{H}^{+}$-ATPase and cytoplasmic calcium ion concentration in the cold hardiness of mung bean (Vigna radiata (L.) Wilczek) tonoplast membranes was demonstrated also by YoSHIDA (1991) and YoshIDA et al. (1993).

\subsection{Genetic control of cold acclimation}

The ability of a plant species to cold acclimate and maintain frost resistance during winter is a complex quantitative trait controlled by the plant genotype and the environment (ROHDE and PULHAM 1960). The inheritance of this trait has been studied perhaps most thoroughly in wheat (see SUTKA 1981, THOMASHOW 1990); the first studies were conducted in 1912 by NILSSON-EHLE. On the basis of the results from crosses between two winter wheat cultivars intermediate in frost hardiness, he concluded that frost hardiness was a quantitative trait controlled by several genes.

Eleven out of the 21 hexaploid wheat chromosomes have been connected to the freezing resistance (THOMASHOW 1990), with most frequent implications to chromosomes 5A and 5D (ROBERTS 1990, SUTKA 1981, VeISZ and SUTKA 1989). Also chromosomes $4 \mathrm{D}$ and $7 \mathrm{~A}$ have been connected to the freezing resistance (SUTKA 1981, VEISZ and SUTKA 1989).

GULLORD (1975) and GULLORD et al. (1975) found that the frost resistance of winter wheat was controlled by several partially dominant and mostly additive genes. At high freezing temperatures the freezing resistance seemed to be controlled by dominant genes, while at low freezing temperatures the control was under recessive ones. SUTKA and VEISZ (1988) studied the influence of gene(s) located in the chromosome $5 \mathrm{~A}$ of winter wheat, and they also found that the additive to dominant gene effect ratio changed depending on the temperature. At a high freezing temperature the frost resistance was dominant, while at a low temperature the frost sensitivity became dominant. Genetic control of cold hardiness was found to be mainly additive also in rye (BRULE-BABEL and FOWLER 1989), triticale (LIMIN and FOWLER 1991), oats (JENKINS 1969) and barley (EUNUS et al. 1962, ROHDE and PULHAM 1960).

Cold hardiness of cultivars is not stable throughout the winter period, but varies according to the changes in temperature and gene action. According to FEDUlov et al. (1990), winter wheat cultivars differed from each other in their timing of gene action promoting freezing resistance in the course of the winter. The studies of VEISZ and SUTKA (1989) indicated also that frost resistance genes are expressed differently during different phases of the cold hardening.

Thus, frost resistance in itself is a very complex genetic character, but it is only part, though an important one, of the total winterhardiness of a plant. Plants have to survive a number of different environmental stresses during winter, the resistance mechanisms of which are mainly unknown. Because of this complexity, the successful results from breeding winter cereals with better winterhardiness have been limited. However, PALTA and SIMON (1993) have proposed that the freezing resistance of plants should be divided into three components: namely cold acclimation, cold avoidance and cold tolerance, which could be selected individually. They assumed that only three to four genes or linkage groups are responsible for freezing resistance and ability to cold acclimate.

In 1970, WEISER was the first to propose that cold acclimation might involve altered gene expression resulting in synthesis of some unique proteins. This hypothesis was supported by GuY et al. (1985), who found rapid and stable changes in the mRNA populations of spinach leaves during cold acclimation. Since then, it has been demonstrated that exposure of the plants to low subfreezing temperatures induce changes in DNA, mRNA, polypeptide and protein synthesis in a variety of species (see GuY 1989, 1990, JOHNSON-FLANAGAN and SiNGH 1988, Li et al. 1989, THOMASHOW 1990 for reviews). Also, changes in the structure and function of enzymes have been reported (CHAREST and 
PHAN 1991, CresPI et al. 1991, GuY et al. 1992, TOGNETTI et al. 1990).

A number of studies indicate that the synthesis of several of the cold regulated polypeptides (and their mRNAs) is correlated with the freezing tolerance of plants. Their appearance coincides with the increase in freezing resistance, they are synthesized during the whole cold acclimation period, and they disappear gradually during deacclimation (CATTIVELLI and BARTELS 1989, GUY and HASKELL 1988, LI et al. 1989, MARENTES et al. 1993, NEVEN et al. 1993). Houde et al. (1992) and PERRAS and SARHAN (1989) found genotypic differences in wheat cultivars in their ability to accumulate certain cold induced polypeptides and their mRNAs during cold acclimation. Thus, at least some of these coldregulated genes seem to be connected to the freezing tolerance of plants and not only to some other aspects of low temperature survival.

\subsection{Freezing stress}

At freezing temperatures ice is formed in plant tissues either intracellularly or extracellularly, depending on the rate of cooling. If a plant is cooled down slowly, its temperature normally drops a few degrees below its freezing point before the ice crystallization occurs. This undercooling or supercooling is in nature normally only about $1-3^{\circ} \mathrm{C}$, but there are known exceptions, e.g. the xylem parenchymal cells of woody plants, where undercooling may occur at temperatures down to $-45^{\circ} \mathrm{C}$ (SAKAI and LARCHER 1987).

In nature the air cooling rates usually never exceed $2^{\circ} \mathrm{C} / \mathrm{h}$ in the subzero range (PALTA 1989). Slow cooling results in ice crystallization in the more dilute extracellular water, and intracellular freezing is avoided. Intracellular freezing occurs only when the cells are cooled down rapidly and it is almost always fatal to the cells. Intracellular freezing is very rare in nature, but it may occur in certain situations like sunscald on trees or rapid freezing of supercooled tissues (LEVITT 1980). Extracellular freezing can be either avoided (e.g. supercooling) or tolerated, depending on the plant species and the season (LEVITT 1980, SAKAI and
LARCHER 1987). The freezing tolerance of plants is enhanced during cold acclimation, and the different mechanisms have been discussed in previous sections.

\subsection{Ice encasement}

Fall floods or winter and spring thaws may result in building up of an ice cover on the ground. Under these conditions perennial herbs are either partially or completely covered by ice. The latter situation is generally highly injurious to the plants (ANDREWS and POMEROY 1975). Plants encased in ice are in a low oxygen environment, and under these conditions the anaerobic respiration becomes dominant, resulting in accumulation of potentially toxic metabolites $\left(\mathrm{CO}_{2}\right.$, lactate, malate, ethanol) and in decreasing production of energy (ANDREWS and POMEROY 1979, GUDLEIFSSON 1986, GUDLEIFSSON and LARSEN 1993, POMEROY and ANDREWS 1989).

Cell membranes are considered to be the primary site of ice encasement injury (HETHERINGTON et al. 1987, 1988, POMEROY and ANDREWS 1989), and like freezing injury the ice encasement injury, is first manifested by the perturbations in the ion transport systems of the membranes (ANDREWS and POMEROY 1989, POMEROY and ANDREWS 1989).

Herbage plant species have different levels of resistance to ice encasement, with perennial grasses reported to be the most resistant ones (see GuDLEIFSSON and LARSEN 1993). Resistance to ice encasement is enhanced during hardening and, according to POMEROY and ANDREWS (1989), the development of ice encasement and freezing tolerance are related. ANDREWS and POMEROY (1975) and MCKERSIE and HuNT (1987) found quite a close correlation between the frost tolerance and ice encasement tolerance of winter wheat cultivars. The same connection was found in winter wheat by ANDREWS and GUDLEIFSSON (1983), but in timothy this correlation was not so clear. POYSA (1984) found that wheat chromosomes $5 \mathrm{~A}$ and $5 \mathrm{D}$ are involved in the ice encasement resistance of wheat. Since these same chromosomes are connected also to the freezing resistance of winter wheat, it may be 
possible that some common resistance mechanisms are involved in both of these stresses.

\subsection{Snow mould}

Snow mould may cause severe damage in all areas with a long lasting snow cover. The most important low temperature parasitic fungi injurious to graminaceous plants are Microdochium nivale (Fries) Samuels \& Hallet (syn. Fusarium nivale (Fr.) Ces), Typhula ishikariensis Imai, $T$. incarnata Lash ex Fr. and Sclerotinia borealis Bub. \& Vleug.. In the USA and Canada, damage is caused also by cottony snow mould Coprinus psychromorbidus Redhead and Traquair (syn. Low Temperature Basidiomycete, or 'LTB' fungus). Snow mould species and their geographic distributions have been described in detail by SMITH (1987) and SMITH et al. (1989).

It is assumed that cold acclimation is a prerequisite for total establishment of snow mould resistance of plants ( $\AA$ RSVOLL 1977, GAUDET and CHEN 1987, GAudet and KozUB 1991, NAKAJIMA and ABE 1990, TAKENAKA and YOSHINO 1989, TRONSMO 1984a, 1984b, 1985a, 1985b, TRONSMO et al. 1993a). Snow mould resistance of plants has been associated with the ability to accumulate large carbohydrate reserves during cold acclimation and with the sparing use of these energy reserves during the long incubation period under snow cover (AMANO and OSANAI 1983, ÅRSVOLL and LARSEN 1977, BENGTSON 1989, BRUEHL 1982). In addition, the size and developmental stage of plants have been found to be important factors in snow mould resistance and the snow mould resistance of plants have often been considered the regrowth capacity of a plant from the crown tissue after snow mould incubation (ÅRSVOLL 1977, BRUEHL 1967a, 1982, GAUDET and CHEN 1987, JAMALAINEN 1974, LiTSCHKO et al. 1988, MiEDANER et al. 1993).

Unlike other snow mould fungi, the pink snow mould (Microdochium nivale) is able to infect plants also during the active growing period, causing brown footrot, leaf necrosis and ear blight, and there seems to be varietal differences in the resistance to this fungus also during the growing season (DAAMEN et al. 1991, ELLEN and LANGERAK 1987, HÄNI 1981). Thus, resistance induced by cold acclimation cannot be a sole explanation of pink snow mould resistance of plants. According to KoczowSKA and PACKA (1986), snow mould resistance could be based on morphological or chemical characters of cells, producing either specific responses to snow mould (KOCZOWSKA 1988, VIRTANEN and HIETALA 1955) or more general responses to the attack of pathogens (TRONSMO et al. 1993a).

Although a significant positive correlation has been reported between frost and snow mould resistance of plants ( $\AA$ RSVOLL 1977, ÅRSVOLL and LARSEN 1977), most studies have concluded that there are different resistance mechanisms behind these two traits (BENGTSSON 1989, BRUEHL and CUNFER 1971, BRUEHL et al. 1975, GAUDET and CHEN 1987, PRONCZUK and ZAGDANSKA 1993, TRONSMO 1984b, 1985a, 1985b).

According to BRUEHL (1982) and КIYOMOTO and BRUEHL (1977), a plant's resistance to snow mould fungi is polygenic and non specific. Snow mould pathogens have little pathogenic specialization, whereby a plant's resistance to one snow mould pathogen means resistance to any (AMANO and OSANAI 1983, BRUEHL 1967b, 1967c, GAUDET and CHEN 1988, JAmALAINEN 1974, MEYer 1986).

\section{AIMS OF THE PRESENT STUDY}

This work was undertaken to determine the differences of overwintering cereal species (winter wheat, rye, triticale, barley) in their ability to cold acclimate, resistance to various winter stresses, and winter survival ability, and the extent of variation in these characteristics within species. The specific objectives were:

1 To find out the differences in the winterhardiness of winter wheat, rye, triticale and barley culti- 
vars in field conditions, and to determine the field survival index (FSI) for each of the cultivars on the basis of their field survival (I, III).

2 To determine the hardening ability of cultivars in the field, and its relation to the general winterhardiness of the cultivars (II, III).

3 To study the changes in the plasma membrane freezing resistance and in the relative contents of plasma membrane fatty acids during cold acclimation (II, III, IV).
4 To study the accumulation of sugars and proline in the course of cold acclimation and its relation to frost resistance (IV).

5 To find out whether there exist differences in the pathogenicity among snow mould (Microdochium nivale) isolates ( $\mathrm{V})$.

6 To develop methods for testing snow mould resistance of plants, and to test the effect of cold acclimation on the induction of snow mould resistance (VI, VII).

\section{MATERIALS AND METHODS}

The basic material of this work comprised 24 winter wheat (Triticum aestivum L.), 13 rye (Secale cereale L.), 5 triticale (X Triticosecale Wittmack) and 11 barley (Hordeum vulgare L.) cultivars. The same cultivars were included also in the Inter-Nordic Winterhardiness Project, within which field trials were carried out during 1989-1992 at altogether 17 locations in all the Nordic countries.

In this study, all the cultivars were subjected to field trials, freezing tests and to some of the snow mould tests. Most of the laboratory tests were carried out only on some of the cultivars.

All the different methods employed in this study, except for the method for analyzing the proline contents of plants, have been described in detail in the respective papers (I-VII).

The proline contents of shoots and roots of two winter wheat cultivars, 'Linna' and 'Apollo' were determined once a week just before hardening and after 1, 2, 3, 4 and 5 weeks of hardening. The analysis was carried out on the same samples which were prepared for the sugar analysis as described in study IV. The proline content was analyzed from $250 \mathrm{mg}$ of dried sample using the method developed by BATES et al. (1973), and the analyses were made with two replications.

\section{RESULTS AND DISCUSSION}

\subsection{Winterhardiness of overwintering cereals}

In extreme environments natural selection favours genotypes which are able to survive unfavourable conditions thus ensuring the production of progenies in the following generations (AASTVEIT 1985) rather than genotypes which are quantitatively productive. This is, however, contradictory to the objectives of modern agriculture which aims at maximal yields. Thus, the most important aim of plant breeding is to combine high yielding capacity and tolerance to different environmental stress factors, either biotic or abiotic, in the same cultivar. In the case of overwintering crops, this means high yield combined primarily with resistance to various winter stresses. Conventional plant breeding can, however, modify only traits in which there exists genotypic variation either within the species or in the near related species which could be crossed with the species in question.

The maximum temperatures tolerated by the most winter hardy cultivars of oats (Avena sativa L.), barley, triticale, wheat and rye are $-17^{\circ} \mathrm{C},-19^{\circ} \mathrm{C}$, 
$-24^{\circ} \mathrm{C},-25^{\circ} \mathrm{C}$ and $-34^{\circ} \mathrm{C}$, respectively (FowLER and LIMIN 1987). This order of species was confirmed also by ANDREws et al. (1986), Cloutier et al. (1990), FowLER and CARLES (1979) and KolAR et al. (1991). In this study, rye turned out to be the most winter hardy species, followed by winter wheat and triticale. The winter survival of barley cultivars was inferior to that of the other species (I).

There has not been much improvement in the winterhardiness of winter cereal cultivars during the last decades (FowLER and LIMIN 1987, HENSLEIGH et al. 1992). To find new sources of cold resistance, FOWLER and LIMIN (1987) screened a number of diverse hexaploid wheat types collected from Afganistan, the secondary center of diversity for bread wheat. However, the winterhardiness of all the studied lines was inferior to that of the hardiest commercial winter wheat cultivars grown in USA. The slow progress in winterhardiness breeding led FowLER and GUSTA (1979) to conclude that the genetic variation in the winterhardiness of winter wheat may be exhausted.

The lack of exploitable genetic variability within the common wheat gene pool has led to efforts to utilize cold hardy relative species, including members of Secale, Agropyron and Triticum, in the breeding of winter hardy wheat cultivars. In spite of some optimistic studies on the possibility of transferring the superior winterhardiness genes from rye to triticale and winter wheat (MÜNTZING 1963), the winterhardiness of triticale cultivars seems to remain at the level of the winter wheat parent (DVORAK and FOWLER 1978, LARTER 1973, LIMIN et al. 1985, LIMIN and FOWLER 1984, 1986, POYSA et al. 1984).

LIMIN and FowLER (1986, 1988, 1991) crossed different Triticum species with species from the genus Agropyron. They found that some hybrids were more cold resistant than their parental species, but they did not, however, exceed the most winter hardy wheat cultivars in winterhardiness. Since the results of these studies were not promising, GALIBA and SUTKA (1989) and LAZAR et al. (1988) examined the possibility to create new genetic variability in winterhardiness of winter wheat by tissue culture. The results indicated that tissue culture induced somaclonal variation in winterhardiness, and some of the regenerated lines were more freeze tolerant than the parental cultivars 'GK Csongor' and 'Norstar'.

One of the reasons for the slow progress in winterhardiness breeding may be the frequent failure of field trials to provide reliable information about the winterhardiness of cultivars, either because of complete winterkill or the lack of it (FOWLER et al. 1976, 1981). During winter period, plants are subjected to many different winter stress factors, both abiotic (frost, heaving, desiccation, ice encasement, flooding) and biotic (snow moulds) which vary in their intensity even within the same trial, leading to high experimental errors (FowLER 1979). Because of this tendency, field trials must often be replicated in order to determine the general winterhardiness of a cultivar. Still, small but important differences among cultivars may remain undetected.

The winter survival of winter wheat, rye, triticale and barley cultivars employed in this study varied also significantly depending on the test location and the year. On the whole, the variation was greatest among the winter wheat and barley cultivars, and smallest among rye cultivars (I). The individual trials which produced similar results were pooled to form larger entities for analysis of variance. In all species the differences between cultivars within these groups were statistically highly significant. The test locations and the years also differed from each other significantly (I). It is probable that each trial was characterized by different combinations of stress factors, and the cultivars were ranked according to their tolerance to the dominant stress factor(s) in each trial. This could explain the genotypeenvironment interactions observed (I). Thus the field trials always characterize the general winter survival ability of cultivars rather than their resistance to specific stress factors. Accordingly, STEPONKUS (1978), SUTKA and VEISZ (1988) and VEISZ and RAJKI (1987) stated that frost resistance of winter wheat cultivars cannot be evaluated under field conditions in countries where the weather during winter is variable, even in the case of trials performed under extreme conditions.

In order to overcome the problems connected to field trials, FOWLER and GUSTA (1979) developed the Field Survival Index (FSI) which was based on 
the relative winterhardiness of winter wheat cultivars in field trials conducted throughout Saskatchewan (Canada) during 1972-1977. The Field Survival Indexes developed in this study for the winter wheat, rye, triticale and barley cultivars (III) correlated highly significantly with the survival data obtained from the Inter-Nordic field trials. The correlations had higher significance in the trials where snow was a more important stress factor than frost, indicating that in Finnish conditions snow is an important environmental factor affecting the winter survival of plants. The FSI values of the cultivars are based on their winterhardiness potential in relation to other cultivars, and they could also be used as standards in other studies on the effects of morphological and physiological factors on the winterhardiness of cultivars in northern conditions.

\subsection{Cold acclimation process in autumn}

The cell plasma membranes are considered to be the primary sites of both frost and ice encasement injury (HETHERINGTON et al. 1987, 1988, LEVITT 1980, PALTA and WeISS 1993, POMEROY and ANDREWS 1989, SINGH and LAROCHE 1988, STEPONKUS 1984, STEPONKUS and LYNCH 1989). According to ARORA and PALTA $(1986,1988)$ the perturbations in the membrane associated $\mathrm{Ca}^{2+}$ transport are indications of an incipient freezing injury, and intracellular calcium is a 'second messenger' which can influence cell metabolism during freezing stress. The freezing injury in plasma membrane results in perturbations in the ion and sugar transport mechanisms, and ions, mainly potassium and to a smaller extent also calcium, leak out from the cells to the extracellular space (PALTA et al. 1977a, 1977b). The amount of leaked ions is related to the severity of the injury in the plasma membrane. The electric conductivity method, also known as the ion leakage method, was introduced into frost hardiness research by DEXTER et al. (1930,1932). This method is based on the assumption that the more the plasma membranes are injured during frost treatment, the more ions are leaked out from the cells into the effusate, and the higher is the conductivity value. The conductivity method has been used quite extensively in evaluating the frost hardiness of trees (ARONSSON and ELIASSON 1970, JOHNSON and GAGNON 1988, MURRAY et al. 1989), Solanum species (VAN SWAAJ et al. 1987), onion (ARORA and PALTA 1986, 1988, PALtA et al. 1977a, 1977b) and cereals and grasses (JENKINS and ROFFEY 1974, LI et al. 1989, PIHAKASKI-MAUNSBACH and HARVEY 1992, ZHANG and WILLISON 1987).

In this study, the leakage test combined with the freezing test and the injury, potassium and calcium indexes (II) were used to study the progress of cold acclimation of winter wheat, rye, triticale and barley cultivars in field conditions, and to test correlations between the cold acclimation and the final winter survival rates of cultivars. According to PALTA et al. (1977a), potassium is the main ion present in the effusate. In a present study the amount of leaked potassium ions exceeded that of leaked calcium about 10-20fold. In most cases, the values obtained for potassium correlated better than those for calcium with the winter survival of cultivars (II,III).

The conductivity and index values fluctuated during the hardening period, but there was a tendency toward decreasing amounts of calcium and potassium ions in the effusate and a corresponding decrease in the conductivity during cold acclimation. Most of the variation in conductivity followed changes in weather conditions during cold acclimation. Warm periods might have induced dehardening resulting in a sudden increase in the conductivity, as the plants were injured during the frost treatment (II,III).

The hardening of winter wheat cultivars seemed to proceed somewhat faster than that of rye, triticale and barley. However, considerable varietal differences were observed. The most winter hardy Finnish cultivars seemed to harden later in the autumn than some winter hardy Canadian and Russian cultivars (ANDREWS et al. 1986, FOWLER and GUSTA 1979, FowLER et al. 1976). On the other hand, the winterhardiness of some Finnish winter wheat cultivars was not especially good in Canadian winter conditions (ANDREWS et al. 1986, BRUEHL 1982). The Finnish cultivars are probably adapted to a longer hardening period and different daylength requirements during hardening, and it is possible 
that they could not reach full hardiness under the Canadian conditions. This points out the difficulty of adopting cultivars or breeding materials from other areas.

On the basis of freezing tests and the following conductivity measurements, winter wheat and rye cultivars seemed to reach quite the same level of frost hardiness during cold acclimation. The most winter hardy triticale cultivars resembled the medium winter hardy winter wheat and rye cultivars, while the winter barley cultivars appeared to be unable to harden to the same level of frost resistance as the other species (II,III). This is in accordance with the winter survival potential of these species. According to POMEROY et al. (1975), the lower overwintering potential of winter barley compared with winter wheat could be a result of both the lower hardening and the lower rehardening capacity after repeated warm periods in winter. METCALF et al. (1970) found that the moisture content of winter barley crowns was higher than that of wheat during cold acclimation, indicating that barley cultivars were not able to adjust their metabolism to the decreasing temperature.

The results from the conductivity test correlated generally better with those Inter-Nordic trials where frost was a more important stress factor than snow. This indicates that the changes in plasma membranes induced by low temperature primarily enhance the frost resistance of plants. Thus, the reason for only moderate correlations between the hardening of the present cultivars and their final winter survival might be that hardening promotes selectively resistance only to certain winter stress factors (e.g. frost) and only slightly affects the others (II,III). Not only cold acclimation in the autumn, but also the ability to reharden after dehardening during thaw periods in the spring is important for the survival potential of a variety (GUSTA and FOWLER 1976a, 1976b). According to FEDUlov et al. (1990) and VeISZ and SuTKA (1989), the rate of dehardening during the winter is cultivar dependent, and the determination of cold hardiness only during the fall is not necessarily an accurate predictor of the final winter survival of a particular cultivar.

\subsection{Changes in plasma membranes during cold acclimation}

Cell plasma membranes are considered to be the primary sites of freezing injury, and both membrane proteins and lipid composition change during cold acclimation. Increased lipid content, as well as increased unsaturation of plasma membrane fatty acids have usually been associated with cold acclimation (DE LA Roche et al. 1975, DE SILVA et al. 1975, GRAHAM and PATTERSON 1982, STEPONKUS 1978). However, most of the published results are based on the analyses carried out using whole plant tissues or crude cell membrane preparations (LARSSON et al. 1992, SUTINEN et al. 1989, VERESHCHAGIN et al. 1990, ZúNIGA et al. 1990), and they characterize merely changes which occur in the whole cell membrane system (e.g. chloroplasts, mitochondria, endoplasmic reticulum), not changes in the plasma membranes per se.

In this study, changes in the plasma membrane lipid composition of two winter wheat cultivars differing in winterhardiness were studied during a 5 week period of cold acclimation (IV). The most pronounced changes in the relative contents of fatty acids in the lipid fractions (neutral lipids, glycolipids and phospholipids) occurred during the first two weeks. Likewise, FARKAS et al. (1975) and STEPONKUS et al. (1990) reported rapid changes in the cryobehaviour and in the fatty acid composition of the plasma membranes during the first week of hardening. Thus, it is possible that plasma membrane lipid alterations are connected to increased resistance of the membrane to initial freezing stress (temperatures down to $-5^{\circ} \mathrm{C}$ ) (STEPONKUS et al. 1990) and that some other changes e.g. in the phospholipid-protein ratio and the accumulation of cryoprotectants, which may protect the membrane proteins or the polar heads of phospholipid molecules (ANCHORDOGUY et al. 1987, CROWE et al. 1990), may increase the freezing resistance of plasma membranes in more severe frosts. This hypothesis was also supported by UEMURA and YOSHIDA (1984), who stated that the increase in unsaturation of plasma membrane fatty acids might be connected to the frost resistance of frost sensitive plants, but has only a small 
influence on the freezing resistance of resistant plants.

The proportion of unsaturated fatty acids in the phospholipid fraction increased only moderately $(5 \%)$ in the winter hardy cultivar 'Linna', while there was a notable increase in the unsaturation in the frost sensitive cultivar 'Apollo' (22\%) (IV). However, at the end of five weeks of cold acclimation the relative content of unsaturated fatty acids was the same $(61 \%)$ in both cultivars, and the difference between cultivars was due to the different degrees of unsaturation in non-acclimated plants (58\% in 'Linna' and 50\% in 'Apollo'). The relative contents of both the linoleic acid (18:2) and linolenic acid (18:3) were higher, and the amount of palmitic acid (16:0) was lower in the non-acclimated 'Linna' than in the non-acclimated 'Apollo'. Thus, the fatty acid composition of non-hardened plants might indicate their frost resistance, as proposed by LARSSON et al. (1992). The relative contents of linoleic and linolenic acids increased and palmitic acid decreased during cold acclimation in both cultivars. The behenic acid (22:0) content increased distinctly in 'Linna' and decreased slightly in 'Apollo' during hardening.

The fatty acid unsaturation decreased in neutral lipid and glycolipid fractions in both cultivars during cold acclimation. The relative contents of both the linoleic and linolenic acid decreased. The stearic acid (18:0) in these lipid fractions increased in both cultivars, but the increase was more pronounced in frost resistant 'Linna'. Also SUTINEN et al. (1989) found increased stearic acid contents in the needles of hardened red pine.

Although part of the changes in lipid composition of plasma membranes could result from the low temperature adjustment of the metabolism, some changes seem to correlate with the enhanced freezing tolerance of plants during cold acclimation (SINGH and LAROCHE 1988).

\subsection{Changes in cell constituents during cold acclimation}

The dry matter content of plants increases during cold acclimation, and this increase is generally con- nected to enhanced freezing resistance (DÖRFFLING et al. 1990, HuNER et al. 1989, KETELEER et al. 1988). The dry matter content of shoots and roots of winter wheat cultivars 'Linna' (winter hardy) and ‘Apollo' (sensitive) increased considerably during a 5 week hardening period $(50 \%$ and $110 \%$ in shoots and roots, respectively), but cultivars 'Linna' and 'Apollo' did not differ from each other in this respect (IV).

As stated earlier (Section 1.2), the growth rate of herbaceous plants is decreased during cold acclimation, but the photosynthesis continues although at a decreased rate. This results in the accumulation of photosynthetic products, mainly different kinds of sugars. In general, sucrose is the most abundant and most commonly accumulated sugar during cold acclimation, and it is also most often associated with increased frost resistance of plants (KETELEER et al. 1988, LARSSON et al. 1992, LIVINGSTON III et al. 1989, SANTOIANI et al. 1993). Also the activity and the amounts of enzymes, e.g. sucrose synthase, sucrose phosphate synthase, sucrose-sucrose fructosyl transferase and invertase ( $\beta$-fructofuranosidase), which are involved in the sucrose metabolism, are increased during cold acclimation (CRESPI et al. 1991, GUY et al. 1992, SANTOIANI et al. 1993, TOGNETTI et al. 1990, TRONSMO et al. 1993b). At least part of this increase seems to be due to the de novo synthesis of these enzymes, since the level of sucrose synthase mRNA has also been shown to increase during cold acclimation (CRESPI et al. 1991). An accumulation of monosaccharides (glucose and fructose) and trisaccharides (raffinose, stachyose) during cold acclimation has also been associated with increased cold resistance (LARSSON et al. 1992, LEVITT 1980). Contrary to these results, GREEN (1983) and GREEN and RATZLAFF (1975) found a negative correlation between the accumulation of soluble sugars and the frost resistance of winter wheat cultivars.

The accumulation of sugars is generally not considerd to be only an outcome of the slower rate of metabolism during cold acclimation, but it is connected to enhanced freezing resistance. Sugars are involved in frost tolerance by three mechanisms (SAKAI and LARCHER 1987): 1. Sugars enhance the osmotic value of the cytoplasm, thus decreasing the 
extracellular ice formation and the cell dehydration. 2 . Sugars serve as the raw material for the metabolism of other cryoprotective substances or as a energy source. 3. Sugars act as cryoprotectants of cells and cell membranes.

The sucrose content increased in both shoots and roots of the winter wheat cultivars 'Linna' and 'Apollo' during the 5-week cold acclimation (IV). This increase was greater in the more winter hardy 'Linna' than in the sensitive 'Apollo'. In accordance with the observations of CRAWFORD and HUXTER (1977), LIVINGSTON III et al. (1989) and POLLOCK (1984), the sucrose content decreased temporarily during the second week of hardening, and then increased again. The second increase was most distinct in the leaves of 'Linna'. The amount of fructose increased in the shoots and roots of both cultivars, and glucose increased in all the other samples, but not in the leaves of Apollo. Also trisaccharide raffinose increased in all the studied samples, but especially in the winter hardy 'Linna'.

The amounts of all ethanol (90\%) soluble sugars (except raffinose and an unknown sugar) were higher in the non-acclimated 'Apollo' than in the non-acclimated 'Linna'. KETELEER et al. (1988) obtained similar results with winter barley.

During active growing period, the excess of photosynthates leads to accumulation of carbohydrates in the form of starch. However, at low temperatures the accumulated starch is readily hydrolyzed into simple sugars (LEVITT 1980, POLLOCK and LLOYD 1987, SAKAI and LARCHER 1987, VOLENEC et al. 1991). The starch content decreased also in the shoots of the two winter wheat cultivars employed, and after a 3-week cold acclimation only traces of starch could be found in the leaf samples. No starch was found in any of the root samples (IV).

In overwintering grass species the accumulation of sucrose during cold acclimation triggers the synthesis of fructans (LIVINGSTON III et al. 1989, POLLOCK 1984, PONTIS 1989, TOGNETTI et al. 1990) which serve as an energy reserve during the winter period and constitute the main carbon source for spring growth (SUZUKI and NASS 1988). A considerable increase in the amount of fructans was found in the shoots and roots of both the studied winter wheat cultivars during the 5-week cold acclimation
(IV). Fructans accumulated in greater quantities in the shoots than in the roots, and more in the winter sensitive cultivar 'Apollo' than in the resistant 'Linna'. LIVINGSTON III et al. (1989) observed the same in winter barley, and they explained it by the different survival strategies of the cultivars. Thus the winter sensitive cultivar transforms more monosaccharides and sucrose into fructans to ensure ample energy reserves for spring growth, while the resistant cultivar leaves more free sugars for cryoprotection. However, according to PONTIS (1989) and SUZUKI and NASS (1988), also fructans are involved in the development of frost resistance of plants by adjusting the osmotic pressure during extracellular ice formation and by acting as cryoprotectants of the cellular membranes.

The levels of free amino acids, especially proline, have been shown to increase during cold acclimation (LEVITT 1980, SAKAI and LARCHER 1987), and this increase is connected to cold hardiness in several species, e.g. maize (SONGSTAD et al. 1990), citrus (KUSHAD and YELENOSKY 1987), potato (VAN SWAAJ et al. 1985) and winter wheat (ChAREST and PHAN 1990, DörFFling et al. 1990, LALK and DÖRFFling 1985, TANTAU and DöRFFling 1991). According to CHAREST and PHAN (1990), proline could be involved in the increased stress resistance of plants by serving as a carbon and nitrogen source for the metabolism of other substances during the stress and recovery period by participating in the cellular osmoregulation and by acting as a cryoprotectant.

The proline content in the shoots and roots of two winter wheat cultivars, 'Linna' and 'Apollo', increased during the 5-week cold acclimation (Fig. 1). This increase was more pronounced in the shoots than in the roots. Also CHAREST and PHAN (1990) found that proline accumulated mainly in the crowns and less in the leaves and roots of winter wheat cultivars. The maximum proline content during the 5-week cold acclimation was found after three weeks of hardening in all samples but the roots of 'Apollo', where the proline content increased steadily during the cold acclimation period (Fig. 1). DöRFFLING et al. (1990) found also a peak in proline content of winter wheat cultivars after three weeks of hardening, but in their study there 

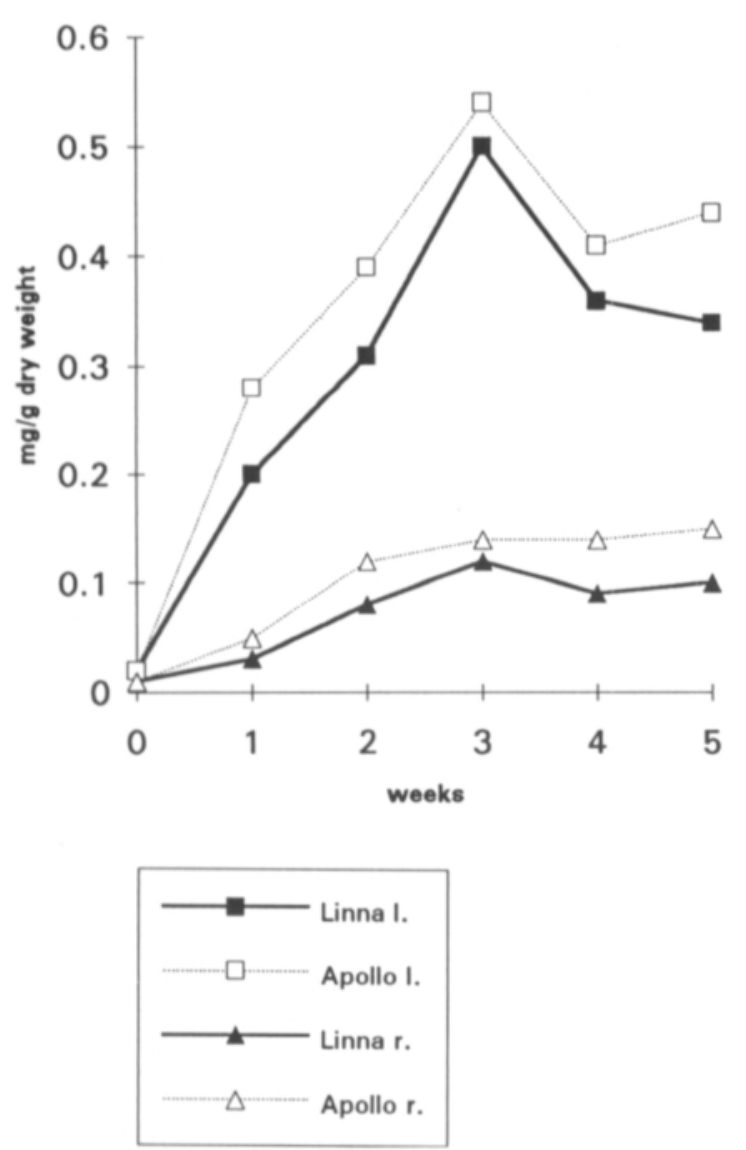

Fig. 1. The accumulation of proline ( $\mathrm{mg} / \mathrm{g}$ dry weight) in the shoots ( $\mathrm{l}$.) and roots (r.) of winter wheat cultivars 'Linna' and 'Apollo' during the 5-week cold acclimation.

was another peak, a more important one, after 10 weeks of cold acclimation.

The proline content was somewhat higher in the shoots and roots of the frost sensitive cultivar 'Apollo' than in the resistant 'Linna' during the whole cold acclimation period. This result is in contradiction to the results of DöRFFLING et al. (1990), LALK and DÖRFFLING (1985) and TANTAU and DöRFFLING (1991), who found a highly significant positive correlation between the proline content and frost hardiness. However, all these tests were carried out under different conditions, which might have contributed to the differences in the results. On the other hand, GUSTA et al. (1982) did not find any correlation between the winterhardi- ness of winter wheat cultivars in field conditions and their proline contents.

\subsection{Snow mould resistance}

The most important biotic stress factor during the winter period is snow mould which causes damage to grasses and overwintering cereals in all areas with long-lasting snow cover.

In Finland, winter cereals are most commonly damaged by pink snow mould (M. nivale) (hereafter termed snow mould). Two varieties of $M$. nivale (var. nivale and var. majus) have been described in literature (SMITH 1987). In both of these varieties, a number of isolates have been found differing from each other e.g. in benzimidazol and benomyl resistance (HAEGERMARK and PETERSSON 1988, TANAKA et al. 1983) and in pathogenicity (MAURIN et al. 1992).

The pathogenicity and enzyme activity (cellulolytic and pectolytic enzymes) varied also in the 10 $M$. nivale isolates collected from eight locations in Southern and Central Finland (V). The pectolytic enzyme activity seemed to be more closely connected to pathogenicity than the cellulolytic activity. Pectolytic enzymes of $M$. nivale were also more effective in macerating the winter rye leaf segments (VI).

Genotypic variation in the snow mould resistance has been found in winter wheat (AMANO and OSANAI 1983, BENGTSSON 1989, BLOMQVIST and JAMALAINEN 1968, BRUEHL 1967a, 1982, BRUEHL et al. 1975, GAUDET and CHEN 1988, GAUDET and KozUB 1991, JAmALAINEN 1974, LiTSCHKo et al. 1988, NAKAJIMA and ABE 1990, TAKENAKA and YOSHINO 1989), in rye (HÄNNINEN and JAMALAINEN 1968, KoczowSKA 1988, KoCZOWSKA and PACKA 1986, KOCZOWSKA and WIWART 1990, MEYER 1986, MIEDANER et al. 1993) and in grasses (ÅrSVOLL 1977, ProNCZUK and ZAGDANSKA 1993, Tronsmo 1984a, 1984b, 1985a, 1985b, 1993), making the breeding of this trait possible. Progress in snow mould resistance breeding has been modest, however. This may be due to the fact that snow mould resistance of cultivars is usually tested in field trials which often turn out to be 
ineffective in screening snow mould ( $M$. nivale) resistance of plants (BENGTSSON 1989, PRONCZUK and ZAGDANSKA 1993, MiedANER et al. 1993). Also in the present study the differences in snow mould resistance of winter wheat, rye and triticale were statistically significant only in about half of the performed trials (VI, VII).

The ability to allocate ample carbohydrate reserves in the crowns of plants during cold acclimation and the sparing use of these reserves (AMANO and OSANAI 1983, ÅrSVOLL and LARSEN 1977, BENGTSSON 1989, BRUEHL 1982, BRUEHL and CUNFER 1971, KIYOMOTO and BRUEHL 1977), as well as the size of the plants ( $\AA$ RSVOLL 1977, BRUEHL 1967a, 1982, BRUEHL et al. 1975, BRUEHL and CunFer 1971, GAUdeT and CHEN 1987, JAMALAINEN 1974, LITSCHKO et al. 1988, MIEDANER et al. 1993) are also associated with increased snow mould resistance. However, all these traits are closely connected to the general winterhardiness of plants, and they describe the same ability of plants to survive the long unfavourable incubation under snow cover as the field trials and snow mould chamber tests (VI, VII). Thus, the more specific snow mould resistance mechanisms of plants may be masked by their general winter survival ability and left unnoticed in the breeding programs. In spite of these drawbaks, few alternative snow mould test methods have been developed (VI).

In this study, the snow mould resistance of winter rye cultivars was studied in field trials and in controlled conditions using three different test methods: snow mould chamber method, enzymatic assay (MCBEATH 1991) and leaf segment test (BAKER and SMITH 1978, BENEDIKZ et al. 1981) (VI). In all the tests the studied eight rye cultivars differed from each other in snow mould resistance statistically significantly. The results of the snow mould chamber test correlated best with the results of the field trials. Also some enzyme treatments (mainly pectolytic enzymes) correlated with field trials, but the results of the leaf segment test did not correlate with any of the other tests (VI). These results indicate that there might be two kinds of snow mould resistance mechanisms in plants: the more general ones which could be tested in field trials or in snow mould chamber tests, and the specific ones which might involve the ability of the plant to prevent the foliar penetration of the fungus, and could be screened in tests where the infection pressure is focused on various parts of the plant. This kind of specific snow mould resistance could be based on morphological or biochemical defence mechanisms of plants (KoczowSKA 1988, KoCZOWSKA and PACKA 1986, VIRTANEN and HIETALA 1955).

To find out whether there exist snow mould resistance mechanisms in plants which are induced without low temperature treatment, snow mould resistance of winter wheat cultivars was studied before hardening, after a 4 week hardening period and during dehardening using detached leaf segments (VII). In all treatments, highly significant differences were found between the studied cultivars in their resistance to snow mould, indicating that some snow mould resistance mechanisms exist at the single leaf level and that cultivars differ from each other in the intensity of these resistance reactions. On the whole, unhardened plants were more resistant to snow mould, and the symptoms on leaf segments were more distinct than in hardened and dehardened plants. No correlation was found between the resistance reactions of unhardened and hardened or dehardened plants, but the resistance of hardened and dehardened plants correlated highly positively. Thus cold acclimation might have disturbed the synthesis of some compounds which are important for snow mould resistance reactions, and this could have brought about the decreased level of snow mould resistance in hardened and dehardened plants.

In a number of studies, a significant positive correlation has been found between snow mould and frost resistance of plants, and these traits have been supposed to be under the same genetic control (ÅRSVOLL 1977, ÅRSVOLL and LARSEN 1977, MEYER 1986). However, most studies have concluded that there exist different genetic mechanisms behind these two traits (BENGTSSON 1989, BRUEHL and CUNFER 1971, GAUDET and CHEN 1987, PRONCZUK and ZAGDANSKA 1993, TRONSMO 1984a, 1985) and, according to GAUDET and CHEN (1988), GAUdeT et al. (1989) and GAUDET and KozuB (1991), these traits might even be 
negatively correlated. In the present study no correlation was found between the frost and snow mould resistance of winter rye or wheat cultivars (VI, VII). Thus there seem to be very specific snow mould resistance mechanisms in plants, some of which might be connected to the general winterhardiness of plants and others either to the general disease resistance of plants (TRONSMO et al. 1993a) or they might be very specific resposes to snow mould (M. nivale) attack.

\section{CONCLUSIONS}

On the basis of the results presented in this study, some concluding remarks could be stated:

1 In field trials, rye was the most winter hardy species followed by winter wheat, triticale and winter barley. Since field trials tend to characterize the general winterhardiness abilities of plants, they are often ineffective in screening the resistance of plants to some specific winter stress factors, such as frost or snow mould.

2 Cold acclimation enhances frost resistance of plants and the general winterhardiness, but part of snow mould ( $M$. nivale) resistance may be induced without low temperature treatment.

3 During cold acclimation, winter wheat cultivars accumulate sugars and proline, and the fatty acid composition of the plasma membrane lipid fractions is changed.

4 Different resistance mechanisms seem to control the freezing resistance and snow mould resistance of winter wheat and rye.

5 Snow mould ( $M$. nivale) isolates seem to differ from each other in their pathogenicity, especially in their use of lytic enzymes while attacking the plant.

6 In spite of the lack of intraspecific variability in the winterhardiness of some species, general winterhardiness within these species could be enhanced by screening different kinds of resistance mechanisms of plants to various specific winter stress factors and combining these resistance mechanisms into new cultivars. 


\section{ACKNOWLEDGEMENTS}

This study was carried out at the Institute of Plant Breeding, Agricultural Research Centre of Finland, Jokioinen, Finland, during 1989-1993.

I wish to express my deepest gratitude to my supervisor, Professor Seppo Pulli, Head of the Institute of Plant Breeding, for giving me the chance to participate in the Inter-Nordic Winterhardiness Project, which made this study possible and for all the valuable advice and support during this work.

I am deeply indebted to Senior Lecturer Terho Valanne, my teacher, for introducing me into the fascinating world of botanical science and for patiently being available whenever I needed help or encouragement during my studies. I want to thank him especially for all the help and advice during this work and for reading through and commenting the manuscript of this thesis in all its phases.

I also want to thank all my colleagues and the personell of the Plant Breeding Institute and the experimental stations for their help and friendship during this work. My special thanks are due to Miss Marja-Leena Manninen for skilful technical assistance in both laboratory and field studies and for patiently trying to understand my sometimes tangled instructions for the various tests and analyses. Mr. Yrjö Karppinen and Mr. Pertti Kavén are warmly thanked for their help in carrying out both the field trials and laboratory experiments. I also want to thank Ilkka Mattila, M.Sc., and Eero Nissilä, M.Sc.Agr., for helping me with the statistical analyses of the data.

My sincere thanks are due to Asko Hannukkala, M.Sc.Agr., for offering me the snow mould isolates used in this study and for all our discussions concerning the snow mould resistance and plant pathology in general.

I wish to thank all the members of the Inter-Nordic Winterhardiness Group for the nice co-operation during these years and for all the vivid conversations about the mechanisms of winterhardiness of plants we have had during our annual meetings. I am especially indebted to Dr. Anne-Marte Tronsmo and Dr. Bjarni Gudleifsson for reading through the manuscript of my doctoral thesis and for all the valuable comments they gave to me.

My heart-felt thanks are due to all my friends especially, Pirkko Rinne and Juha Vilkki, for their companionship and encouraging attitude whenever I felt tired with this sometimes endless work.

Professor Olavi Junttila and Senior Lecturer Seppo Pihakaski have reviewed the manuscript and suggested many improvements. I appreciate their constructive criticism.

Sevastiana Ruusamo, M.A., is thanked for revising the language of this thesis.

Financial support from the Finnish Ministry of Agriculture and Forestry, the SNP (Samnordic Planteforedling) and the Agricultural Research Centre of Finland is gratefully acknowledged.

I want to thank all my relatives for their understanding and all the help during this work, especially my sister Tiina for sharing with me the joys and sorrows of everyday life and for cheering me up with the calls from the 'Mattila farm'. My very special thanks are due to my mother and father for their never-failing love and support during all my studies.

Finally, my warmest thanks are due to my family. I want to thank my children Mikko, Riikka and Reetta for trying to understand mother's long working hours and endless eagerness to 'play computer games' and for teaching me, what is really important in life. The love and support of my husband Reino made this study possible and I want to thank him for taking care of all the daily routines while I was preparing my thesis.

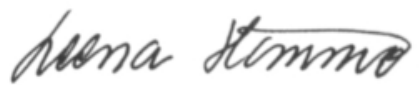




\section{REFERENCES}

AASTVErT, K. 1985. Genetic aspects of climatic adaptations in plants. In: Kaurin, Å., Junttila, O. \& Nilsen, J. (eds.). Plant Production in the North. Norwegian University Press, Tromsø, Oslo, Bergen, Stavanger. p. 23-42.

Amano, Y. \& Osanai, S.I. 1983. Winter wheat breeding for resistance to snow mold and cold hardiness III. Varietal differences of ecological characteristics on cold acclimation and relationships of them to resistance. Bulletin of Hokkaido Prefectural Agricultural Experimental Stations 50: 83-95.

Anchordoguy, T.J., Rudolph, A.S., CARPenter, J.F. \& Crowe, J.H. 1987. Modes of interaction of cryoprotectants with membrane phospholipids during freezing. Cryobiology 24: 324-331.

AndRews, C.J. \& Gudleifsson, B.E. 1983. A comparison of cold hardiness and ice encasement tolerance of timothy grass and winter wheat. Canadian Journal of Plant Science 63: 429-435.

— \& Pomeroy, M.K. 1975. Survival and cold hardiness of winter wheats during partial and total ice immersion. Crop Science 15: 561-566.

— \& Pomeroy, M.K. 1979. Toxicity of anaerobic metabolites accumulating in winter wheat seedlings during ice encasement. Plant Physiology 64: 120-125.

— \& Pomeroy, M.K. 1989. Ice encasement injury at the cellular and membrane level. Búvísindi Icelandic Agricultural Sciences 2: 57-61.

-, Pomeroy, M.K. \& De La Roche, I.A. 1974. Changes in cold hardiness of overwintering winter wheat. Canadian Journal of Plant Science 54: 9-15.

—, Pomeroy, M.K. \& Seaman, W.L. 1986. The response of fall sown cereals to winter stresses in eastern Ontario. Canadian Journal of Plant Science 66: 25-37.

ANDREws, J.E. 1960. Cold hardiness of sprouting wheat as affected by duration of hardening and hardening temperature. Canadian Journal of Plant Science 40: 94-103.

Aronsson, A. \& Eliasson, L. 1970. Frost hardiness in Scots pine (Pinus silvestris L.). I. Conditions for tests on hardy plant tissues and for evaluation of injuries by conductivity measurements. Studia Forestalia Suecica 77: 1-30.

ArorA, R. \& PAltA, J.P. 1986. Protoplasmic swelling as a symptom of freezing injury in onion bulb cells. Its simulation in extracellular $\mathrm{KCl}$ and prevention by calcium. Plant Physiology 82: 625-629.

— \& PALTA, J.P. 1988. In vivo perturbation of membrane associated calcium by freeze-thaw stress in onion bulb cells. Simulation of this perturbation in extracellular $\mathrm{KCl}$ and alleviation by calcium. Plant Physiology 87: 622-628.

Årsvol., K. 1977. Effects of hardening, plant age, and development in Phleum pratense and Festuca pratensis on resistance to snow mould fungi. Meldinger fra Norges LandbrHøgskole 56. 14 p.

— \& LARSEN, A. 1977. Effects of nitrogen, phosphorus, and potassium on resistance to snow mould fungi and on freezing tolerance in Phleum pratense. Meldinger fra Norges LandbrHøgskole 56. 14 p.
BAKER, E.A. \& SMITH, J.M. 1978. Development of resistant and susceptible reactions in wheat on inoculation with Septoria nodorum. Transactions of the British Mycological Society 71: 475-482.

Barta, A.L. \& Hodges, H.F. 1970. Characterization of photosynthesis in cold hardening winter wheat. Crop Science 10: 535-538.

Bates, L.S., Waldren, R.P. \& Teare, I.D. 1973. Rapid determination of free proline for water-stress studies. Plant and Soil 39: 205- 207.

Benedikz, P.W., Mappledoram, C.J. \& Scott, P.R. 1981. A laboratory technique for screening cereals for resistance to Septoria nodorum using detached seedling leaves. Transactions of the British Mycological Society 77: 667668.

Bengtsson, B. 1989. Soluble sugar changes during winter and resistance to snow mould in winter wheat. Journal of Phytopathology 124: 162-170.

Blomevist, H.H. \& Jamalainen, E.A. 1968. Preliminary tests on winter cereal varieties of resistance to low temperature parasitic fungi in controlled conditions. Maataloustieteellinen Aikakauskirja 40: 88-95.

Bolduc, R., Comeau, A., Couture, L. \& StPierre, C.A. 1988. Resistance to alternating freeze and thaw stresses in wheat, rye, triticale and foxtail barley. Canadian Journal of Plant Science 68: 331-335.

BRUEHL, G.W. 1967a. Effect of plant size on resistance to snowmold of winter wheat. Plant Disease Reporter 51: 815-819.

- 1967b. Correlation of resistance to Typhula idahoensis, $T$. incarnata, and Fusarium nivale in certain varieties of winter wheat. Phytopathology 57: 308-310.

- 1967c. Lack of significant pathogenic specialization within Fusarium nivale, Typhula idahoensis, and $T$. incarnata and correlation of resistance in winter wheat to these fungi. Plant Disease Reporter 51: 810-814.

- 1982. Developing wheats resistant to snow mold in Washington State. Plant Disease 66: 1090-1095.

— \& CUNFER, B. 1971. Physiologie and Environmental factors that affect the severity of snow mold of wheat. Phytopathology 61: 792- 799.

—, Kiyomoto, R., Peterson, C. \& Nagamitsu, M. 1975. Testing winter wheats for snow mold resistance in Washington. Plant Disease Reporter 59: 566-570.

BRULE-BABEL, A.L. \& Fowler, D.B. 1989. Genetic control of cold hardiness and vernalization requirement in rye. Genome 32: 19-23.

CAPELL, B. \& DörfFling, K. 1989. Low temperature-induced changes of abscisic acid contents in barley and cucumber leaves in relation to their water status. Journal of Plant Physiology 135: 571-575.

Cattivelli, L. \& Bartels, D. 1989. Cold-induced mRNAs accumulate with different kinetics in barley coleoptiles. Planta 178: 184-188.

Charest, C. \& Phan, C.T. 1990. Cold acclimation of wheat (Triticum aestivum): Properties of enzymes involved in 
proline metabolism. Physiologia Plantarum 80: 159-168.

— \& Phan, C.T. 1991. Kinetic properties of four enzymes involved in proline metabolism in cold-acclimated wheat. Journal of Experimental Botany 42: 673-678.

CHEN, T.H.H. \& GustA, L.V. 1983. Abscisic acid-induced freezing resistance in cultured plant cells. Plant Physiology 73: 71-75.

Christersson, L. 1985. Frost damage during the growing season. In: Kaurin, Å., Junttila, O. \& Nilsen, J. (eds.). Plant Production in the North. Norwegian University Press, Tromsø, Oslo, Bergen, Stavanger. p. 191-198.

Cloutier, Y. \& Andrews, C.J. 1984. Efficiency of cold hardiness induction by desiccation stress in four winter cereals. Plant Physiology 76: 595-598.

- Comenu, A., Bernier-Cardou, M. \& Angers, D.A. 1990. Effect of soil water content on the winter survival of winter wheat, rye and triticale. Canadian Journal of Plant Science 70: 667-675.

Crawford, R.M.M. \& Huxter, T.J. 1977. Root growth and carbohydrate metabolism at low temperatures. Journal of Experimental Botany 28: 917-925.

Crespi, M.D., Zabaleta, E.J., Pontis, H.G. \& Salerno, G.L. 1991. Sucrose synthase expression during cold acclimation in wheat. Plant Physiology 96: 887-891.

Crowe, J.H., Carpenter, J.F., Crowe, L.M. \& AnchorDOGUY, T.J. 1990. Are freezing and dehydration similar stress vectors? A comparison of modes of interaction of stabilizing solutes with biomolecules. Cryobiology 27: 219-231.

DaAmen, R.A., Langerak, C.J. \& Stol, W. 1991. Surveys of cereal diseases and pests in the Netherlands. 3. Monographella nivalis and Fusarium spp. in winter wheat fields and seed lots. Netherlands Journal of Plant Pathology 97: 105-114.

De La Roche, I.A., Pomeroy, M.K. \& Andrews, C.J. 1975. Changes in fatty acid composition in wheat cultivars of contrasting hardiness. Cryobiology 12: 506-512.

De Silva, N.S., Weinberger, P., Kates, M. \& De La Roche, I.A. 1975. Comparative changes in hardiness and lipid composition in two near- isogenic lines of wheat (spring and winter) grown at $2^{\circ} \mathrm{C}$ and $24^{\circ} \mathrm{C}$. Canadian Journal of Botany 53: 1899-1905.

Dexter, S.T., Tottingham, W.E. \& Graber, L.F. 1930. Preliminary results in measuring the hardiness of plants. Plant Physiology 5: 215-223.

—, Tottingham, W.E. \& Graber, L.F. 1932. Investigations of the hardiness of plants by measurement of electrical conductivity. Plant Physiology 7: 63-78.

Dhindsa, R.S., Monroy, A., Wolfraim, L. \& Dong, G. 1993. Signal transduction and gene expression during cold acclimation of alf-alfa. In: Li, P.H. \& Christersson, L. (eds.). Advances in Plant Cold Hardiness. CRC Press, Boca Raton, Ann Arbor, London, Tokyo. p. 57-71.

Dórflling, K., Flores, A., Grau, A. \& Capell, B. 1989. Effect of new synthetic abscisic acid analogues in combination with tetcyclacis on chilling and freezing resistance in crop plants. Acta Horticulturae 239: 187-196.

-, Schulenburg, S., Lesselich, G. \& Dörffling, H. 1990. Abscisic acid and proline levels in cold hardened winter wheat leaves in relation to variety-specific differences in freezing resistance. Journal of Agronomy and Crop Science 165: 230-239.

DVORAK, J. \& FowLer, D.B. 1978. Cold hardiness potential of triticale and tetraploid rye. Crop Science 18: 477-478.

EAGLes, C.F. \& WILLIAMS, J. 1992. Hardening and dehardening of Lolium perenne in response to fluctuating temperatures. Annals of Botany 70: 333-338.

Ellen, J. \& LangeraK, C.J. 1987. Effects of plant density and nitrogen fertilization in winter wheat (Triticum aestivum L.). 2. Incidence of Gerlachia nivalis and Fusarium spp. related to yield losses. Netherlands Journal of Agricultural Science 35: 155-162.

Eunus, A.M., Johnson, L.P.V. \& AKsel, R. 1962. Inheritance of winterhardiness in an eighteen-parent diallel cross of barley. Canadian Journal of Genetics and Cytology 4: 356-376.

Farkas, T., Deri-Hadlaczky, E. \& Belea, A. 1975. Effect of temperature upon linolenic acid level in wheat and rye seedlings. Lipids 10: 331-334.

Fedulov, Y.P., Puchkov, Y.M., Belikova, N.M. \& NaBAKov, G.D. 1990. Change in structure of frost resistance of winter wheat during wintering. Soviet Agricultural Sciences (USA) 6: 1-4.

FowLER, D.B. 1979. Selection for winterhardiness in wheat. II. Variation within field trials. Crop Science 19: 773775 .

— \& Carles, R.J. 1979. Growth, development, and cold tolerance of fall-acclimated cereal grains. Crop Science 19: $915-922$.

— \& Gusta, L.V. 1977. Influence of fall growth and development on cold tolerance of rye and wheat. Canadian Journal of Plant Science 57: 751-755.

— \& Gusta, L.V. 1979. Selection for winterhardiness in wheat. I. Identification of genotypic variability. Crop Science 19: 769-772.

— \& GUSTA, L.V. 1982. Fall growth and cold acclimation of winter wheat and rye differentially fertilized with phosphorus. Agronomy Journal 74: 539-540.

-, Gusta, L.V., Bowren, K.E., Crowle, W.L., Mallough, E.D., McBean, D.S. \& McIver, R.N. 1976. Potential for winter wheat production in Saskatchewan. Canadian Journal of Plant Science 56: 45-50.

-, Gusta, L.V. \& TYler, N.J. 1981. Selection for winter hardiness in wheat. III. Screening methods. Crop Science 21: 896-901.

— \& Limin, A.E. 1987. Exploitable genetic variability for cold tolerance in commercially grown cereals. Canadian Journal of Plant Science 67: 278.

Galiba, G. \& SuTKA, J. 1989. Frost resistance of somaclones derived from Triticum aestivum L. winter wheat calli. Plant Breeding 102: 101-104.

Gaudet, D.A., Bhalla, M.K., Clayton, G.W. \& Chen, T.H.H. 1989. Effect of cottony snow mold and low temperatures on winter wheat survival in central and northern Alberta. Canadian Journal of Plant Pathology 11: 291296.

— \& CHEN, T.H.H. 1987. Effects of hardening and plant age on development of resistance to cottony snow mold 
(Coprinus psychromorbidus) in winter wheat under controlled conditions. Canadian Journal of Botany 65: 1152 1156.

— \& CHEN, T.H.H. 1988. Effect on freezing resistance and low- temperature stress on development of cottony snow mold (Coprinus psychromorbidus) in winter wheat. Canadian Journal of Botany 66: 1610-1615.

— \& KozuB, G.C. 1991. Screening winter wheat for resistance to cottony snow mold under controlled conditions. Canadian Journal of Plant Science 71: 957-965.

Graham, D. \& Patterson, B.D. 1982. Responses of plants to low, non-freezing temperatures: proteins, metabolism and acclimation. Annual Review of Plant Physiology 33: 347-372.

GREEN, D.G. 1983. Soluble sugar changes occurring during cold hardening of spring wheat, fall rye and alfalfa. Canadian Journal of Plant Science 63: 415-420.

— \& RAtZlafF, C.D. 1975. An apparent relationship of soluble sugars with hardiness in winter wheat varieties. Canadian Journal of Botany 53: 2198-2201.

Griffith, M. \& McInTYRE, H.C.H. 1990. The effect of photoperiod and temperature on growth and frost resistance of winter rye root systems. Physiologia Plantarum 79: 519-525.

— \& MCINTYRE, H.C.H. 1993. The interrelationship of growth and frost tolerance in winter rye. Physiologia Plantarum 87: 335-344.

Grossi, M., Cattivelli, L., Terzi, V. \& Stanca, A.M. 1992. Modification of gene expression induced by ABA, in relation to drought and cold stress in barley shoots. Plant Physiology and Biochemistry 30: 97-103.

Grout, B.W.W. 1987. Higher plants at freezing temperatures. In: Grout, B.W.W. \& Morris, G.J. (eds.). The Effect of Low Temperatures on Biological Systems. Edward Arnold, London, Australia, USA. p. 293-314.

GudLEIFsson, B.E. 1986. Ice encasement damages on grasses and winter cereals. NJF Seminar Nr. 84. Lantbruksväxternas Övervintring. p. 59-65.

- \& LARSEN, A. 1993. Ice encasement as a component of winter kill in herbage plants. In: Li, P.H. \& Christersson, L. (eds.). Advances in Plant Cold Hardiness. CRC Press, Boca Raton, Ann Arbor, London, Tokyo. p. 229-249.

GuLLORD, M. 1975. Genetics of freezing hardiness in winter wheat (Triticum aestivum L.). Dissertation for the degree of doctor of philosophy, Michigan State University. 70 p.

—, Olien, C.R. \& Everson, E.H. 1975. Evaluation of freezing hardiness in winter wheat. Crop Science 15: 153-157.

GustA, L.V. 1985. Freezing resistance in plants. In: Kaurin, Å., Junttila, O. \& Nilsen, J. (eds.). Plant Production in the North. Norwegian University Press, Tromsø, Oslo, Bergen, Stavanger. p. 219-235.

- 1986. The induction and maintenance of cold hardiness in winter cereals. NJF-seminar Nr. 84 Lantbruksväxternas Övervintring. p. 9-27.

— \& FowLER, D.B. 1976a. Effects of temperature on dehardening and rehardening of winter cereals. Canadian Journal of Plant Science 56: 673-678.

— \& Fowler, D.B. 1976b. Dehardening and rehardening of spring-collected winter wheats and a winter rye. Cana- dian Journal of Plant Science 56: 775-779.

—, Fowler, D.B. \& TYleR, N.J. 1982. Factors influencing hardening and survival in winter wheat. In: Li, P.H. \& Sakai, A. (eds.). Plant Cold Hardiness and Freezing Stress Mechanisms and Crop Implications. Vol 2. Academic Press, New York. p. 23-40.

GuY, C. 1989. Cold acclimation and freezing tolerance in hardy plants: an inducible response. In: Randall, D.D. \& Blevins, D.G. (eds.). Current Topics in Plant Biochemistry and Physiology. Vol.8. University of Missouri-Columbia. p. 69-79.

GuY, C.L. 1990. Cold acclimation and freezing stress tolerance: role of protein metabolism. Annual Review of Plant Physiology and Plant Molecular Biology 41: 187-223.

— \& Haskel., D. 1988. Detection of polypeptides associated with the cold acclimation process in spinach. Electrophoresis 9: 787-796.

—, Huber, J.L.A. \& Huber, S.C. 1992. Sucrose phosphate synthase and sucrose accumulation at low temperature. Plant Physiology 100: 502-508.

—, Niemi, K.J. \& BrAmBL, R. 1985. Altered gene expression during the cold acclimation of spinach. Proceedings of the National Academy of Sciences of the United States 82: 3673-3677.

Haegemark, U. \& Petersson, E. 1988. Resultat från broddbehandlings försök i höstråg mot snömögel (Gerlachia nivalis). Växtskyddsnotiser 52: 124-126.

HĀNI, F. 1981. Zur Biologie und Bekämpfung von Fusariosen bei Weizen und Roggen. Phytopathologische Zeitschrift 100: 44-87.

Hänninen, H., HăkKınen, R., HaRı, P. \& Koskı, V. 1990. Timing of growth cessation in relation to climatic adaptation of northern woody plants. Tree Physiology 6: 29-39.

Hānninen, P. \& Jamalainen, E.A. 1968. Overwintering of winter cereals in Central Finland. Annales Agriculturae Fenniae 7: 194-218.

Hensleigh, P.F., Blake, T.K. \& Welty, L.E. 1992. Natural selection on winter barley composite cross XXVI affects winter survival and associated traits. Crop Science 32: 57-62.

Hetherington, P.R., Broughton, H.L. \& McKersie, B.D. 1988. Ice encasement injury to microsomal membranes isolated from winter wheat crowns. II. Changes in membrane lipids during ice encasement. Plant Physiology 86: 740-743.

-, McKersie, B.D. \& Borochov, A. 1987. Ice encasement injury to microsomal membranes from winter wheat crowns. I. Comparison of membrane properties after lethal ice encasement and during post-thaw period. Plant Physiology 85: 1068-1072.

-, McKersie, B.D. \& Keeler, L.C. 1990. The influence of mineral nutrition on the expression of traits associated with the winterhardiness of two winter wheat (Triticum aestivum L.) cultivars. Canadian Journal of Plant Science 70: 443-454.

Houde, M., Danyluk, J., Laliberté, J.F., Rassart, E., Dhindsa, R.S. \& Sarhan, F. 1992. Cloning, characterization, and expression of a cDNA encoding a 50-kilo- 
dalton protein specifically induced by cold acclimation in wheat. Plant Physiology 99: 1381-1387.

Huner, N.P.A., Krol, M., Williams, J.P. \& Maissan, E. 1989. Membrane assembly during acclimation to low temperature: lipid-protein interaction. In: Cherry, J.H. (ed.). Environmental stress in plants: biochemical and physiological mechanisms. Springer-Verlag, Berlin. p. 267-279.

Hurry, V.M., GARDESTRŌM, P. \& ÖQUIST, G. 1993a. Reduced sensitivity to photoinhibition following frost-hardening of winter rye is due to increased phosphate availability. Planta 190: 484-490.

-, Lapointe, L., Boese, S., Krol, M., ÖQuist, G., Malek, L. \& HunER, N.P.A. 1993b. Effects of growth at cold hardening temperatures and temperature shifts on resistance to photoinhibition. In: Li, P.H. \& Christersson, L. (eds.). Advances in Plant Cold Hardiness. CRC Press, Boca Raton, Ann Arbor, London, Tokyo. p. 103-112.

IswARI, S. \& PALTA, J.P. 1989. Plasma membrane $\mathrm{H}^{+}$ATPase as a site of functional alteration during cold acclimation and freezing injury. In: Li, P.H. (ed.). Low Temperature Stress Physiology in Crops. CRC Press, Boca Raton, Florida. p. 123-137.

JAmAlainen, E.A. 1974. Resistance in winter cereals and grasses to low-temperature parasitic fungi. Annual Review of Phytopathology 12: 281-302.

JENKINS, G. 1969. Transgressive segregation for frost resistance in hexaploid oats (Avena spp.). The Journal of Agricultural Science 73: 477-482.

— \& Rofrey, A.P. 1974. A method of estimating the cold hardiness of cereals by measuring electrical conductance after freezing. The Journal of Agricultural Science 83: 87-92.

Johnson, J.D. \& GaGnON, K.G. 1988. Assessing freeze damage in loblolly pine seedlings: A comparison of ethane production to electrolyte leakage. New Forests 2: 65-72.

Johnson-Flanagan, A.M. \& Singh, J. 1988. Protein synthesis and freezing tolerance in plant cells. Critical Review of Plant Science 7: 279-302.

JUNTTILA, O. \& KAURIN, Å. 1989. Environmental control of growth behavior and cold hardiness in arctic and subarctic plants. In: Li, P.H. (ed.). Low Temperature Stress Physiology in Crops. CRC Press, Boca Raton, Florida. p. 91-106.

—, Svenning, M.M. \& Solmeim, B. 1990. Effects of temperature and photoperiod on frost resistance of white clover (Trifolium repens) ecotypes. Physiologia Plantarum 79: 435-438.

KACPERSKA, A. 1985. Biochemical and physiological aspects of frost hardening in herbaceous plants. In: Kaurin, Å., Junttila, O. \& Nilsen, J. (eds.). Plant Production in the North. Norwegian University Press, Tromsø, Oslo, Bergen, Stavanger. p. 99-115.

- 1989. Metabolic consequences of low temperature stress in chilling-insensitive plants. In: Li, P.H. (ed.). Low Temperature Stress Physiology in Crops. CRC Press, Boca Raton, Florida. p. 27-40.

- 1993. Water potential alterations - A prerequisite or a triggering stimulus for the development of freezing toler- ance in overwintering herbaceous plants. In: Li, P.H. \& Christersson, L. (eds.). Advances in Plant Cold Hardiness. CRC Press, Boca Raton, Ann Arbor, London, Tokyo. p. 73-91.

KACPERSKA-PALACZ, A. 1978. Mechanism of cold acclimation in herbaceous plants. In: Li, P.H. and Sakai, A. (eds.). Plant Cold Hardiness and Freezing stress. Mechanisms and Crop Implications. Academic Press, New York, San Francisco, London. p. 139-152.

Keteleer, A., VanMechelen, B. \& TobBack, P. 1988. The evolution of dry matter, soluble protein and sugar content during frost hardening in some barley and wheat varieties differing in hardening capacity. Archives Internationales de Physiologie et de Biochimie 96: 17.

KiYomoto, R.K. \& BRUEHL, G.W. 1977. Carbohydrate accumulation and depletion by winter cereals differing in resistance to Typhula idahoensis. Phytopathology 67: 206-211.

Koczowska, I. 1988. The active resistance of rye to snow mould caused by Fusarium nivale (Fr.) Ces.. Acta Academiae Agriculturae ac Technicae Olstenensis, Agricultura 47: 101-111.

— \& PACKA, D. 1986. Anatomical-physiological resistance of rye plants to infection by Fusarium nivale (Fr.) Ces.. Acta Academiae Agriculturae ac Technicae Olstenensis, Agricultura 43: 129-142.

— \& WiWART, M. 1990. The reaction of the rye and Triticale cultivars to different isolates of Fusarium nivale (Fr.) Ces. Biuletyn Instytutu Hodowli i Aklimatyzacji Rolin Nr. 173-174: 71-73.

Kolar, S.C., Hayes, P.M., Chen, T.H.H. \& Linderman, R.G. 1991. Genotypic variation for cold tolerance in winter and facultative barley. Crop Science 31: 1149-1152.

Kushad, M.M. \& Yelenosky, G. 1987. Evaluation of polyamine and proline levels during low temperature acclimation of citrus. Plant Physiology 84: 692-695.

LAl., I. \& Dörffling, K. 1985. Hardening, abscisic acid, proline and freezing resistance in two winter wheat varieties. Physiologia Plantarum 63: 287-292.

LÅng, V., Heino, P. \& Palva, E.T. 1989. Low temperature acclimation and treatment with exogenous abscisic acid induce common polypeptides in Arabidopsis thaliana (L.) Heynh. Theoretical and Applied Genetics 77: 729734.

LARSEN, A. 1978. Freezing tolerance in grasses. Effect of different water contents in growth media. Meldinger fra Norges LandbrHøgskole 57. 19 p.

Larsson, S., Johansson, L.Å. \& Svenningsson, M. 1992. Soluble sugars and membrane lipids in winter wheats (Triticum aestivum $\mathrm{L}$ ) during cold acclimation. European Journal of Agronomy 1: 85-90.

LARTER, E.N. 1973. Progress in the development of triticale in Canada. Proceedings of International Triticale Symposium. El Batan, Mexico. p. 69-74.

Lazar, M.D., Chen, T.H.H., Gusta, L.V. \& Kartha, K.K. 1988. Somaclonal variation for freezing tolerance in a population derived from norstar winter wheat. Theoretical and Applied Genetics 75: 480-484.

LEE, S.P. \& CHEN, T.H.H. 1993. Molecular biology of plant 
cold hardiness development. In: Li, P.H. \& Christersson, L. (eds.). Advances in Plant Cold Hardiness. CRC Press, Boca Raton, Ann Arbor, London, Tokyo. p. 1-29.

LevitT, J. 1980. Responses of Plants to Environmental Stresses: Chilling, Freezing and High Temperature Stresses. Ed 2, Vol.1. Academic Press, New York. 497 p.

LI, P.H., Ryu, S.B., Tseng, M.J. \& Chen, T.H.H. 1989. Induction of plant cold hardiness. In: Randall, D.D. \& Blevins, D.G. (eds.). Current Topics in Plant Biochemistry and Physiology. Vol.8. University of Missouri-Columbia. p. 21-40.

Limin, A.E., Dvorak, J. \& Fowler, D.B. 1985. Cold hardiness in hexaploid triticale. Canadian Journal of Plant Science 65: 487-490.

— \& Fowler, D.B. 1984. The effect of cytoplasm on cold hardiness in alloplasmic rye (Secale cereale L.) and triticale. Canadian Journal of Genetics and Cytology 26: 405-408.

— \& Fowler, D.B. 1986. Use of related species for the improvement of cold tolerance in wheat. Canadian Journal of Plant Science 67: 282.

— \& Fowler, D.B. 1988. Cold hardiness expression in interspecific hybrids and amphiploids of the Triticae. Genome 30: 361-365.

— \& Fowler, D.B. 1991. Breeding for cold hardiness in winter wheat: problems, progress and alien gene expression. Field Crops Research 27: 201-218.

Lineberger, R.D. \& Steponkus, P.L. 1980. Cryoprotection by glucose, sucrose and raffinose to chloroplast thylakoids. Plant Physiology 65: 298-304.

Litschкo, L.D., Burbee, L.L., Goylty, L.G., Hunt, L.A. \& McKersie, B.D. 1988. An evaluation of winter wheat for resistance to the snow mold fungi Microdochium nivale (Fr.) Samu \& Hall and Typhula ishikariensis Imai. Canadian Plant Disease Survey 68: 161-168.

Livingston III, D.P., Olien, C.R. \& Freed, R.D. 1989. Sugar composition and freezing tolerance in barley crowns at varying carbohydrate levels. Crop Science 29: 12661270.

Lynch, D.V. \& Steponkus, P.L. 1987. Plasma membrane lipid alterations associated with cold acclimation of winter rye seedlings (Secale cereale L. cv Puma). Plant Physiology 83: 761-767.

MCBEATH, J.F. 1991. In vitro detection of resistance to snow mould fungi. NJF-Seminar Nr. 188 Disease Resistance in Agricultural Crops. p. 8.

MCKersie, B.D. \& Hunt, L.A. 1987. Genotypic differences in tolerance of ice encasement, low temperature flooding, and freezing in winter wheat. Crop Science 27: 860-863.

Marentes, E., Griffith, M., Mlynarz, A. \& Brush, R.A. 1993. Proteins accumulate in the apoplast of winter rye leaves during cold acclimation. Physiologia Plantarum 87: 499-507.

Maurin, N., LAMKadmi, Z. \& Some, A. 1992. Morphological, biological and biochemical characterization of 31 strains of Microdochium nivale (Fusarium nivale). Hodowla Roślin Aklimatyzacja i Nasiennictwo 37 (special edition nr. 1): 153-162.

Maximov, N.A. 1912. Chemische Schulzmittel der Pflanzen gegen Erfrieren. Berichte der Deutschen Botanischen Gesellschaft 30: 52-65.

Metcalf, E.L., Cress, C.E., Olein, C.R. \& Everson, E.H. 1970. Relationship between crown moisture content and killing temperature for three wheat and three barley cultivars. Crop Science 10: 362-365.

MEYER, J. 1986. Testing snow mould resistance in winter cereals. NJF Seminar Nr. 84. Lantbruksväxternas Överwintring. p. 139-144.

Miedaner, T., Höter, H. \& Geiger, H.H. 1993. Development of resistance test for winter rye to snow mold (Microdochium nivale) under controlled environment conditions in regard to field inoculations. Canadian Journal of Botany 71: 136-144.

Môntzing, A. 1963. Cytogenetics and breeding studies in Triticale. Proceedings of the 2nd International Wheat Genetics Symposium, Lund, Sweden. p. 291-300.

Murray, M.B., CAPE, J.N. \& Fowler, D. 1989. Quantification of frost damage in plant tissues by rates of electrolyte leakage. The New Phytologist 113: 307-311.

NAKAJIMA, T. \& ABE, J. 1990. A method for assessing resistance to the snow molds Typhula incarnata and Microdochium nivale in winter wheat incubated at the optimum growth temperature ranges of the fungi. Canadian Journal of Botany 68: 343-346.

Neven, L.G., Haskel., D.W., Hofig, A., Li, Q.B. \& GuY, C.L. 1993. Characterization of a spinach gene responsive to low temperature and water stress. Plant Molecular Biology 21: 291-305.

Nilsson-Ehle, H. 1912. Zur Kenntnis der Erblichkeitsverhältnisse der Eigenschaft Winterfestighkeit beim Weizen. Zeitschrift für Pflanzenzüchtung 1: 3-12.

Nordin, K., LÀng, V., MăntYlä, E., Heino, P., Welin, B., Baudo, M., Holmström, K.O. \& Palva, T. 1993. Role of $\mathrm{ABA}$ in regulation of low temperature-induced genes in Arabidopsis thaliana. In: Li, P.H. \& Christersson, L. (eds.). Advances in Plant Cold Hardiness. CRC Press, Boca Raton, Ann Arbor, London, Tokyo. p. 45-56.

ÖQUIST, G. \& HUNER, N.P.A. 1993. Cold-hardening-induced resistance to photoinhibition of photosynthesis in winter rye. Planta 189: 150-156.

PALTA, J.P. 1989. Plasma membrane ATPase as a key site of perturbation in response to freeze-thaw stress. In: Randall, D.D. \& Blevins, D.G. (eds.). Current Topics in Plant Biochemistry and Physiology. Vol.8. University of Missouri-Columbia. p. 41-68.

- 1992. Mechanisms for obtaining freezing stress resistance in herbaceous plants. In: Stalker, H.T. \& Murphy, J.P. (eds.). Plant Breeding in the 1990s. Proceedings of the Symposium on Plant Breeding in the 1990s. C.A.B International, Wallingford, UK. p. 219-250.

—, Levirt, J. \& Stadelmann, E.J. 1977a. Freezing injury in onion bulb cells I. Evaluation of the conductivity method and analysis of ion and sugar efflux from injured cells. Plant Physiology 60: 393-397.

—, Levitt, J. \& Stadelmann, E.J. 1977b. Freezing injury in onion bulb cells II. Post-thawing injury or recovery. Plant Physiology 60: 398-401.

— \& Li, P.H. 1980. Alterations in membrane transport prop- 
erties by freezing injury in herbaceous plants. Evidence against rupture theory. Physiologia Plantarum 50: 169-175.

— \& Simon, G. 1993. Breeding potential for improvement of freezing stress resistance: genetic separation of freezing tolerance, freezing avoidance, and capacity to cold acclimate. In: Li, P.H. \& Christersson, L. (eds.). Advances in Plant Cold Hardiness. CRC Press, Boca Raton, Ann Arbor, London, Tokyo. p. 299-310.

— \& WeIss, L.S. 1993. Ice formation and freezing injury: an overwiev on the survival mechanisms and molecular aspects of injury and cold acclimation in herbaceous plants. In: Li, P.H. \& Christersson, L. (eds.). Advances in Plant Cold Hardiness. CRC Press, Boca Raton, Ann Arbor, London, Tokyo. p. 143-176.

Perras, M. \& Sarhan, F. 1989. Synthesis of freezing tolerance proteins in leaves, crown, and roots during cold acclimation of wheat. Plant Physiology 89: 577-585.

Pihakaski-Maunsbach, K. \& Harvey, D.M.R. 1992. X-ray microanalytical (EDX) investigation of potassium distributions in mesophyll cells of non-acclimated and coldacclimated rye leaves. Plant Cell and Environment 15: 585-591.

Pollock, C.J. 1984. Sucrose accumulation and the initiation of fructan biosynthesis in Lolium temulentum L. The New Phytologist 96: 527-534.

— \& LLoYD, E.J. 1987. The effect of low temperature upon starch, sucrose and fructan synthesis in leaves. Annals of Botany 60: 231-235.

Pomeroy, M.K. \& Andrews, C.J. 1989. Low temperature injury in winter cereals. In: Li, P.H. (ed.). Low Temperature Stress Physiology in Crops. CRC Press, Boca Raton, Florida. p. 107-122.

-, Andrews, C.J. \& FedaK, G. 1975. Cold hardening and dehardening responses in winter wheat and winter barley. Canadian Journal of Plant Science 55: 529-535.

Pontis, H.G. 1989. Fructans and cold stress. Journal of Plant Physiology 134: 148-150.

Poysa, V.W. 1984. The genetic control of low temperature, ice encasement and flooding tolerance by chromosomes 5A, 5B and 5D in wheat. Cereal Research Communications 12: 135-141.

—, Knoblauch, C.J., McKersie, B.D. \& Reinbergs, E. 1984. Low temperature tolerance of octoploid triticale and its parental species grown in southern Ontario. Canadian Journal of Plant Science 64: 451-456.

Pronczuk, M. \& Zagdanska, B. 1993. Effect of Microdochium nivale and low temperature on winter survival of perennial ryegrass. Journal of Phytopathology 138: 1-8.

Reaney, M.J.T. \& GuSTA, L.V. 1987. Factors influencing the induction of freezing tolerance by abscisic acid in cell suspension cultures of Bromus inermis Leyss and Medicago sativa $\mathrm{L}$. Plant Physiology 83: 423-427.

Repo, T. 1992. Seasonal changes of frost hardiness in Picea abies and Pinus sylvestris in Finland. Canadian Journal of Forest Research 22: 1949-1957.

ROBERTS, D.W.A. 1990. Identification of loci on chromosome $5 \mathrm{~A}$ of wheat involved in control of cold hardiness, vernalization, leaf length, rosette growth habit, and height of hardened plants. Genome 33: 247-259.
Robertson, A.J., Churchill, G.C. \& Gusta, L.V. 1993. The role of plant growth regulators on the freezing tolerance of winter annual cereals and cell suspension cultures. In: Li, P.H. \& Christersson, L. (eds.). Advances in Plant Cold Hardiness. CRC Press, Boca Raton, Ann Arbor, London, Tokyo. p. 253-271.

Rohde, C.R. \& Pulham, C.F. 1960. Heritability estimates of winter hardiness in winter barley determined by the standard unit method of regression analysis. Agronomy Journal 52: 584-586.

Røsnes, K., Junttil.a, O., Ernstsen, A. \& Sandli, N. 1993. Development of cold tolerance in white clover (Trifolium repens $\mathrm{L}$.) in relation to carbohydrate and free amino acid content. Acta Agriculturae Scandinavica B 43: 151-155.

SAKAI, A. \& LARCher, W. 1987. Frost Survival of Plants: Responses and Adaptation to Freezing stress. Springer Verlag, Berlin, Heidelberg, New York. 321 p.

Santarius, K. \& Giersch, C. 1983. Cryopreservation of spinach chloroplast membranes by low-molecularweight carbohydrates. Cryobiology 20: 90-99.

Santolani, C.S., Tognetti, J.A., Pontis, H.G. \& Salerno, G.L. 1993. Sucrose and fructan metabolism in wheat roots at chilling temperatures. Physiologia Plantarum 87: 84-88.

Singh, J. \& LAROCHE, A. 1988. Freezing tolerance in plants: a biochemical overview. Biochemistry and Cell Biology 66: 650-657.

Sıösetr, H. 1964. Studies on frost hardening in plants. Acta Agriculturae Scandinavica 14: 178-192.

SмrтH, J.D. 1987. Winter-hardiness and overwintering diseases of amenity turfgrasses with special reference to the Canadian Prairies. Agriculture Canada Research Branch Technical Bulletin 1987-12E. 192 p.

—, JACKson, N. \& Woolmouse, A.R. 1989. Fungal Diseases of Amenity Turf Grasses, Ed 3. E. \& F.N. Spon, London, New York. 401 p.

Songstad, D.D., Duncan, D.R. \& Widholm, J.M. 1990. Proline and polyamine involvement in chilling tolerance of maize suspension cultures. Journal of Experimental Botany 41: 289-294.

StefFen, K.L. \& Palta, J.P. 1989. Growth and development temperature influences level of tolerance to high light stress. Plant Physiology 91: 1558-1561.

Steponkus, P.L. 1978. Cold hardiness and freezing injury of agronomic crops. Advances in Agronomy 30: 51-98.

- 1984. Role of the plasma membrane in freezing injury and cold acclimation. Annual Review of Plant Physiology 35: 543-584.

— \& LYNCH, D.V. 1989. Freeze/thaw-induced destabilization of the plasma membrane and the effects of cold acclimation. Journal of Bioenergetics and Biomembranes 21: 21-41.

—, LynCh, D.V. \& Uemura, M. 1990. The influence of cold acclimation on the lipid composition and cryobehaviour of the plasma membrane of isolated rye protoplasts. Philosophical Transactions. Biological Scienses 326: 571583.

-, Uemura, M., Balsamo, R.A., Arvinte, T. \& Lynch, D.V. 1988. Transformation of the cryobehavior of rye proto- 
plasts by modification of the plasma membrane lipid composition. Proceedings of the National Academy of Sciences of the United States of America 85: 9026-9030.

Sutinen, M.L., RYbarczyK, S.J. \& Palta, J.P. 1989. Seasonal changes in polar lipid fatty acid composition coincide with changes in freezing stress resistance in pine needles. In: Randall, D.D. \& Blevins, D.G. (eds.). Current Topics in Plant Biochemistry and Physiology. Vol. 8. University of Missouri-Columbia. p. 286.

SuTKA, J. 1981. Genetic studies of frost resistance in wheat. Theoretical and Applied Genetics 59: 145-152.

— \& Veisz, O. 1988. Reversal of dominance in a gene on chromosome $5 \mathrm{~A}$ controlling frost resistance in wheat. Genome 30: 313-317.

SuzuKı, M. \& NAss, H.G. 1988. Fructan in winter wheat, triticale, and fall rye cultivars of varying cold hardiness. Canadian Journal of Botany 66: 1723-1728.

TAKenaka, S. \& Yoshino, R. 1989. Development of suitable technique for testing resistance of wheat cultivars to three snow mold diseases. Japan Agricultural Research Quarterly 22: 284-289.

Tanaka, F., Sarto, I., Miyaima, K., Tsuchiya, S. \& Tsuboki, K. 1983. Occurrence of Triophanate-methyl tolerant isolates of Fusarium nivale (=Gerlachia nivalis), a causal fungus of snow mold of winter wheat, in Japan. Annals of the Phytopathological Society of Japan 49: 565-566.

Tantau, H. \& Dörffling, K. 1991. In vitro-selection of hydroxyproline-resistant cell lines of wheat (Triticum aestivum): accumulation of proline, decrease in osmotic potential, and increase in frost tolerance. Physiologia Plantarum 82: 243-248.

Tномаsноw, M.F. 1990. Molecular genetics of cold acclimation in higher plants. Advances in Genetics 28: 99-131.

-, Gilmour, S.J. \& Lin, C. 1993. Cold-regulated genes of Arabidopsis thaliana. In: Li, P.H. \& Christersson, L. (eds.). Advances in Plant Cold Hardiness. CRC Press, Boca Raton, Ann Arbor, London, Tokyo. p. 31-44.

Tognetti, J.A., Salerno, G.L., Crespi, M.D. \& Pontis, H.G. 1990. Sucrose and fructan metabolism of different wheat cultivars at chilling temperatures. Physiologia Plantarum 78: 554-559.

Tronsmo, A.M. 1984a. Predisposing effects of low temperature on resistance to winter stress factors in grasses. Acta Agriculturae Scandinavica 34: 210-220.

$-1984 \mathrm{~b}$. The effects of hardening, dehardening and freezing on resistance to snow mould fungi in timothy and meadow fescue. In: Riley, H. \& Skjelvåg, A.O. (eds.). Proceedings of the 10th general meeting of the European Grassland Federation. p. 292-296.

- 1985a. Induced resistance to biotic stress factors in grasses by frost hardening. In: Kaurin, Å., Junttila, O. \& Nilsen, J. (eds.). Plant Production in the North. Norwegian University Press, Troms $ø$, Oslo, Bergen, Stavanger. p. 127-133.

- 1985b. Effects of dehardening on resistance to freezing and to infection by Typhula ishikariensis in Phleum pratense. Acta Agriculturae Scandinavica 35: 113-116.

- 1993. Resistance to winter stress factors in half-sib families of Dactylis glomerata, tested in a controlled environ- ment. Acta Agriculturae Scandinavica B 43: 89-96.

-, Gregersen, P., Huel jord, L., S andal, T., Bryngelsson, T. \& Collinge, D.B. 1993a. Cold-induced disease resistance. In: Fritig, B. \& Legrand, M. (eds.). Mechanisms of Plant Defence Responses. Kluwer Academic Publishers, Dordrecht, The Netherlands. p. 369.

-, Kobro, G., Morgenlie, S. \& Flengsrud, R. 1993b. Carbohydrate content and glycosidase activities following cold hardening in two grass species. Physiologia Plantarum 88: 689-695.

Tyler, N.J., Gusta, L.V. \& Fowler, D.B. 1981. The effect of a water stress on the cold hardiness of winter wheat. Canadian Journal of Botany 59: 1717-1721.

Uemura, M. \& Yoshida, S. 1984. Involvement of plasma membrane alterations in cold acclimation of winter rye seedlings (Secale cereale L. cv Puma). Plant Physiology 75: 818-826.

Van Swaai, A.C., Jacobsen, E. \& Feenstra, W.J. 1985. Effect of cold hardening, wilting and exogenously applied proline on leaf proline content and frost tolerance of several genotypes of Solanum. Physiologia Plantarum 64: 230-236.

-, Talsma, K., Krugsheld, H., Jacobsen, E. \& Feenstra, W.J. 1987. Frost tolerance in cell cultures of potato. Physiologia Plantarum 69: 602-608.

VeIsZ, O. \& RAJKI, E. 1987. Frost resistance in various winter wheat varieties during winter. Acta Agronomica Hungarica 36: 285-294.

— \& SutKA, J. 1989. The relationships of hardening period and the expression of frost resistance in chromosome substitution lines of wheat. Euphytica 43: 41-45.

Vereshchagin, A.G., Trunova, t..., Shayakhmetova, I.S. \& TsydendambaEv, V.D. 1990. On the role of cell membrane lipids in cold hardening of winter wheat leaves and crowns. Plant Physiology and Biochemistry 28: 623-630.

Virtanen, A.I. \& Hietal.A, P.K. 1955. 2(3)-Benzoxazolinone, an anti-Fusarium factor in rye seedlings. Acta Chemica Scandinavica 9: 1543-1544.

Volenec, J.J., Boyce, P.J. \& Hendershot, K.L. 1991. Carbohydrate metabolism in taproots of Medicago sativa L. during winter adaptation and spring regrowth. Plant Physiology 96: 786-793.

WEISER, C.J. 1970. Cold resistance and injury in woody plants. Science 169: 1269-1278.

Willemot, C. \& Pelletier, L. 1979. Effect of drought on frost resistance and fatty acid content of young winter wheat plants. Canadian Journal of Plant Science 59: 639. 643.

WILSON, J.M. 1987. Chilling injury in plants. In: Grout, B.W.W. \& Morris, G.J. (eds.). The Effect of Low Temperatures on Biological Systems. Edward Amold, London, Australia, USA. p. 271-292.

Yoshida, S. 1991. Chilling-induced inactivation and its recovery of tonoplast $\mathrm{H}^{+}$-ATPase in mung bean suspension cultures. Plant Physiology 95: 456-460.

-, Hattanda, Y. \& Suyama, T. 1993. Variations in the chilling sensitivity of suspension-cultured cells of mung bean (Vigna radiata (L.) Wilczek) during the growth cycle. Plant Physiology 34: 673-679. 
— \& Uemura, M. 1984. Protein and lipid composition of isolated plasma membranes from orchard grass (Dactylis glomerata L.) and changes during cold acclimation. Plant Physiology 75: 31-37.

Zhang, M.I.N. \& WiLlison, J.H.M. 1987. An improved conductivity method for the measurement of frost hardiness. Canadian Journal of Botany 65: 710-715.
Zúñiga, G.E., Fernandez, J., Cristi, R., Alberdi, M. \& CorCuera, L.J. 1990. Lipid changes in barley seedlings subjected to water and cold stress. Phytochemistry 29: 3087-3090.

\title{
SELOSTUS
}

\section{Syysviljojen talvehtiminen — lajien ja lajikkeiden väliset erot ja karaisun vaikutus talvenkestävyyteen}

\author{
LEENA MAARIT HÖMMÖ \\ Maatalouden tutkimuskeskus
}

Tutkimuksessa selvitettiin syysviljalajien ja lajikkeiden talvenkestävyyttä ja talvenkestävyyteen vaikuttavia tekijöitä sekä kenttäkokeissa että laboratoriotestien avulla.

Kenttäkokeet perustettiin vuosittain (1989-1992) kuudelle koepaikalle (Mietoinen, Jokioinen, Pälkäne, Anjalankoski, Laukaa, Sotkamo) ja tämän lisäksi lajikkeet testattiin yhteispohjoismaisen talvehtimisprojektin aikana 11 koepaikalla Ruotsissa, Norjassa, Tanskassa ja Islannissa.

Kenttăkokeissa määritettiin lajikkeiden talvehtimisprosentit (eloonjäämis-\% keväällä) ja lumihomekestävyys. Talvehtimisprosenttien perusteella laskettiin lajikkeille myös talvenkestävyysindeksit, joita voidaan käyttää vertailuaineistona erilaisissa talvenkestävyystutkimuksissa. Koeaineiston perusteella ruis on syysviljoista talvenkestävin. Syysvehnä ja ruisvehnä ovat talvenkestävyydeltään hyvin lähellä toisiaan ja huomattavasti syysohraa kestävämpiä. Lajikkeet erosivat talvenkestävyydeltään toisistaan tilastollisesti erittäin merkitsevästi kokeissa, joiden aikana oli ollut kylmä ja runsasluminen talvi. Koejakson aikana talvehtimisolosuhteet vaihtelivat suuresti koepaikasta ja vuodesta riippuen, ja lajikkeiden talvenkestävyysjärjestys näytti olevan riippuvainen eri talvistressien yhdistelmästä.

Lajikkeiden karaistumista seurattiin syksyllä 1990 ja 1991 pellolta kerätyistä lehtinäytteistä käyttäen pakkastestejä ja näihin liittyviä johtokykymittauksia. Kaikkien syysviljalajien pakkasenkestävyys parani karaisun edistyessä. Tutkittujen ruis-, syysvehnä- ja ruisvehnälajikkeiden pakkasenkeståvyydessä ei ollut suuria eroja karaisuvaiheen lopussa, kun taas syysohrien pakkasenkestävyys jäi tutkituista lajeista selvästi heikoimmaksi. Karaisun aikana kasvien aineenvaihdunnassa tapahtuu lukuisia muutoksia, joiden seurauksena myös kasvien kemiallinen koostumus muuttuu. Talvenkestävän syysvehnän 'Linnan' ja huonosti talvehtivan 'Apollon' kuiva-aine, sokeri- ja proliinipitoisuus nousi karaisun aikana ja myös solukalvojen rasvahappokoostumuksessa tapahtui selviä muutoksia. Osa näistä muutoksista näytti olevan sidoksissa myös lajikkeiden talvenkestävyyteen.

Lumihome on tärkein talvehtivia kasveja tuhoava bioottinen tekijä. Syysviljalajikkeiden lumihomekestävyyttä tutkittiin sekä kenttäkokeissa, että erilaisilla laboratoriotesteillä, ja syysviljojen lumihomekestävyydessä näytti olevan selviä lajikekohtaisia eroja. Koska eri testimenetelmillä saadut tulokset poikkesivat varsin selvästi toisistaan on mahdollista, että kasvien lumihomekestävyys on useiden erillisten resistenssimekanismien säätelemä. Osa näistä saattaa indusoitua myös ilman kylmäkäsittelyä.

Syysviljojen talvenkestävyyttä testataan yleensä kenttäkokeilla. Talvehtimisolosuhteet ovat kuitenkin vain harvoin optimaaliset lajikkeiden talvenkestävyyserojen testaamiseen ja lajikkeiden välisiä eroja on usein vaikea havaita luotettavasti. Parhaimmillaankin kenttäkokeet mittaavat lăhinnä lajikkeiden yleistä talvenkestävyyttä, ja lajikkeiden valinta erillisten talvistressien, kuten pakkanen ja lumihome, suhteen on yleensä mahdollista vain laboratorio-olosuhteissa. Laboratoriotesteissä on mahdollista testata kasvien talvenkestävyyden eri osa-alueita altistamalla kasvit erilaisille talvistresseille, tai näiden yhdistelmille. Näin on mahdollista valita erilaisia talvenkestävyyteen liittyviä geenikombinaatioita, joita edelleen yhdistelemällä voidaan kehittää uusia, entistä monipuolisemman talvenkestävyyden omaavia syysviljalajikkeita. 


\title{
Winterhardiness of some winter wheat (Triticum aestivum), rye (Secale cereale), triticale ( $\times$ Triticosecale) and winter barley (Hordeum vulgare) cultivars tested at six locations in Finland
}

\author{
LEENA HÖMMÖ and SEPPO PULLI
}

\begin{abstract}
Но̆ммö, L. \& Pulli, S. 1993. Winterhardiness of some winter wheat (Triticum aestivum), rye (Secale cereale), triticale ( $\mathrm{X}$ Triticosecale) and winter barley (Hordeum vulgare) cultivars tested at six locations in Finland. Agric. Sci. Finl. 2: 311-327. (Agric. Res. Centre of Finland, Inst. Plant Breed., FIN-31600 Jokioinen, Finland.)

The winterhardiness of 24 winter wheat, 13 rye, 5 triticale and 11 winter barley varieties of different origins was tested at six locations in Finland in 1989-1992. The survival ability of the cultivars, their resistance to snow mould (Microdochium nivale) and the correlations between these traits and the growth habit and growth stage were determined.

The trials were grouped on the basis of variety ranking, and the differences between the varieties within each group were studied by the analysis of variance. Statistically highly significant differences between varieties were found in all cases. The wintering conditions during the trials were very variable, and this brought about differences in the ranking of cultivars in different trials. In most cases the genotypic-environmental interactions could be explained by the different genetic systems controlling the tolerance to various winter stresses and changes in their intensity.
\end{abstract}

Key words: cold tolerance, frost resistance, Microdochium nivale, snow mould

\section{Introduction}

Winter cereals are grown mainly in temperate regions of the world. The ability of species to acclimate (harden) during autumn to survive the extreme conditions in winter determines their northern limit of distribution. During the hardening period, numerous changes take place in the plant (LEVITT 1972). The rates and extent of these changes depend upon both the genotype of the plant and the prevailing environmental conditions (FOWLER and GUSTA 1977). According to FOWLER and LIMIN (1987), the maximum coldhardiness of the most winter hardy cultivars of barley (Hordeum vulgare $\mathrm{L}$.$) , triticale (x Triticosecale Wittmack),$ wheat (Triticum aestivum L.) and rye (Secale ce- reale $\mathrm{L}$.) is $-19^{\circ} \mathrm{C},-24^{\circ} \mathrm{C},-25^{\circ} \mathrm{C}$ and $-34^{\circ} \mathrm{C}$, respectively. This order of coldhardiness is also reflected in their commercial cultivation areas in the Nordic countries: Denmark, Sweden, Norway, Finland and Iceland. Winter barley is grown almost only in Denmark $(175,000$ ha in 1993) and in Southern Sweden $(10,700$ ha in 1992). The winter triticale also meets its northern limit in Denmark $(1,000$ ha in 1993) and in Southern Sweden (19,400 ha in 1992). Winter wheat is grown up to the southern parts of Finland (Fig. 1), and the southern and costal areas of Norway. The area of winter wheat cultivation was in Denmark 610,000 ha (1993), in Sweden 235,000 ha (1992) and in Norway 33,000 ha (1993). In Finland, during the last five years the winter wheat area has varied between 46,400 ha 
(1991) and 12,300 ha (1992), depending on both the climatic factors and policy. The northern limit of distribution of rye is in central Finland (Fig.1). The area of rye cultivation was in Denmark 70,000 ha (1993), in Sweden 34,100 ha (1992) in Norway 2,000 ha (1993) and in Finland it has ranged between 84,800 ha (1990) and 10,600 ha (1992) during the last five years. In Iceland, only some experiments have been made on winter cereals, but there is no commercial cultivation.

Since the spring forms of species avoid the possible economic losses caused by the winter damages, spring barley is cultivated in all the Nordic countries but Denmark, and spring wheat exceeds winter wheat in Finland and in Norway. The higher yield level, the better drought resistance in early summer and early harvesting in autumn have, however, made the winter forms very important also in the northern limits of distribution. This has urged the development of better agronomic practices for cultivating winter cereals (ANDERSEN 1992, ANDERSSON 1986, BENGTSSON 1986, BRUEHL 1982, FOWLER et al. 1976, GUDLEIFSSON 1986, GUSTA 1986, HÄNNINEN and JAMALAINEN 1968, HETHERINGTON et al. 1990, JAMALAINEN 1974, NISSINEN 1986, Olvång 1992, POHJaKallio et al. 1962, POMEROY and ANDREWS 1989, PULLI 1986, SMITH 1986, 1987 and URVAS 1986) and also to find some new resources of winterhardiness to be utilized in developing new, more winter resistant cultivars (ANDREWS et al. 1986, BRULE-BABEL and FOWLER 1987, DVORAK and FOWLER 1978, FOWLER et al. 1977, Hensleigh et al. 1992, JenKINS 1963, LAZAR et al. 1988, LIMIN et al. 1985, LIMIN and FOWLER 1984, 1986, 1988, 1991, VEISZ and RAJKI 1987). Although numerous sophisticated tests have been developed to measure the hardening ability and resistance of breeding material against different winter stresses, field trials are, in most cases, still used to give the ultimate evaluation of the winter hardiness of the studied lines or cultivars.

In the present study, the winterhardiness of winter wheat, rye, triticale and winter barley varieties was tested in field trials established at six locations in Finland (Fig.1) in 1989-1992. On the basis of these results the tested cultivars were arranged according to their resistance against different winter stresses, and the suitability of the experimental sites for screening the winterhardiness of tested species was discussed.

\section{Material and methods}

The field trials comprised 24 ( 22 in 1989-90) winter wheat, 13 (11 in 1989-90) winter rye, 5 winter triticale and 11 (10 in 1989-90) winter barley varieties. The varieties and their origins are listed in Tables 1 and 7.

The field trials were carried out at four locations: Anjalankoski $\left(60^{\circ} 43^{\prime} \mathrm{N}, 26^{\circ} 48^{\prime} \mathrm{E}\right)$, Pälkäne $\left(61^{\circ} 20^{\prime} \mathrm{N}, 24^{\circ} 13^{\prime} \mathrm{E}\right)$, Laukaa $\left(62^{\circ} 20^{\prime} \mathrm{N}, 26^{\circ} 10^{\prime} \mathrm{E}\right)$ and Sotkamo $\left(64^{\circ} 06^{\prime} \mathrm{N}, 28^{\circ} 20^{\prime} \mathrm{E}\right)$ in 1989-1990. In 1990-1991 and 1991-1992 trials were established also at Jokioinen $\left(60^{\circ} 49^{\prime} \mathrm{N}, 23^{\circ} 30^{\prime} \mathrm{E}\right)$ and Mietoinen ( $60^{\circ} 38^{\prime} \mathrm{N}, 21^{\circ} 51$ 'E) (Fig.1).

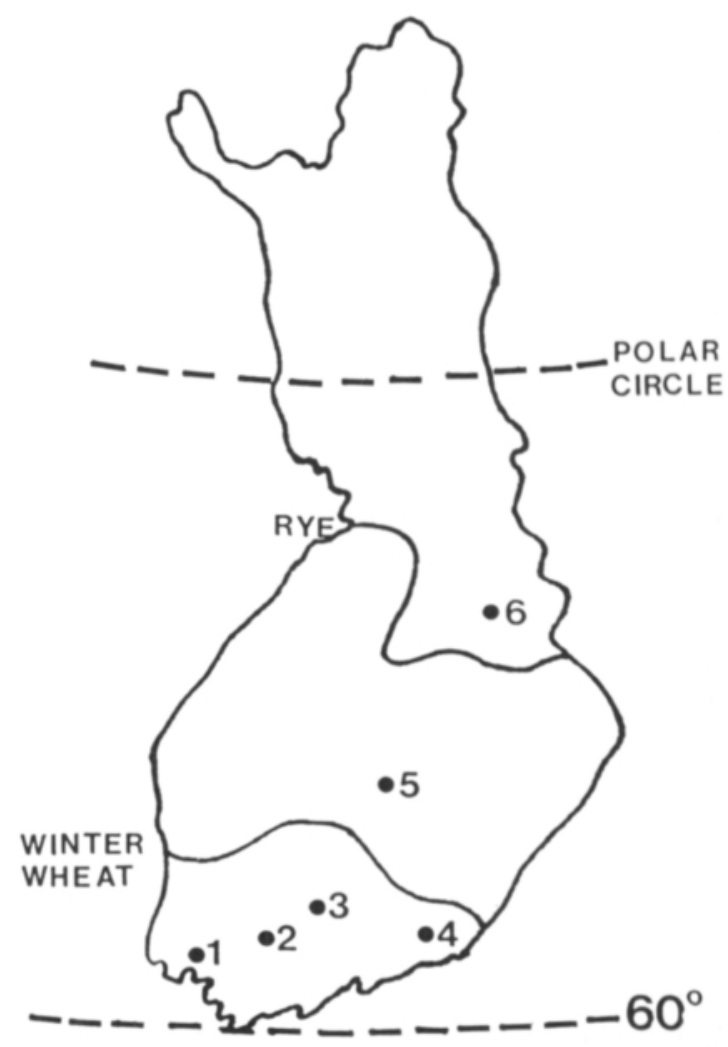

Fig. 1. Locations of the field trials. $1=$ Mietoinen, $2=$ Jokioinen, 3 = Pälkäne, 4 = Anjalankoski, $5=$ Laukaa and $6=$ Sotkamo. The northern limits of winter wheat and rye cultivation are also shown on the map. 
The trials were completely randomized with four replicates and the cultivars were sown in $1 \mathrm{~m}$ rows. The trials were sown in August and they were fertilized in autumn and in spring according to the normal practice of the experimental stations.

In autumn, the growth habit of varieties was determined using a scoring system of 1 (prostrate) to 5 (erect). In autumn 1990 at Jokioinen and Mietoinen, 10 plants of each variety were selected randomly from the first replicate and the number of leaves (growth stage) and the height of the plants were measured.

The winter survival rate of varieties was determined by counting the plants both in the autumn and in the spring soon after the snow had melted. At the same time, damage to the plants caused by snow mould (Microdochium nivale (Fr.) Samu \& Hall) was rated using the scoring system of 0 (totally undamaged) to 10 (dead).

The climatic data concerning the temperatures and the snow cover at the experimental sites was obtained from the Monthly Reports of the Meteorological Institute of Finland.

Differences in winter survival abilities between experimental varieties were studied using the analysis of variance and Tukey's studentized range test. The arcsin modification of data was done before the analysis.

The correlations between winter survival of varieties, snow mould resistance, growth habit, number of leaves and height of plants were determined using the correlation analysis.

The field trials were part of the Inter-Nordic "Winterhardiness" Project. The same winter wheat, rye, triticale and winter barley varieties were tested in the same years in all the Nordic countries at 17 locations. The test locations were in Denmark Tystofte, Risø, Abed, Pajberg and Sejet; in Sweden: Svalöv and Uppsala; in Norway: Apelsvoll, Kvithamar and Vågønes and in Iceland: Möðruvellir. The Inter-Nordic field trial results collected by Dr Kurt Hjortsholm were kindly offered for use in this study. The data was divided into two groups on the basis of the assumed main stress factor, snow or frost, and the winter survival of varieties was determined within each group. The correlations between the combined Inter-Nordic field test results and the overwintering results in Finland were determined.

\section{Results}

The level of general survival of each studied species varied greatly depending on the year and experimental site (Fig. 2). The variation was greater among winter wheat and winter barley varieties than among the rye and triticale varieties (Fig. 2). Winter rye was the most winter hardy species, winter wheat was somewhat hardier than winter triticale, and winter barley was inferior in this respect. Since wheat variety 'Vitus' behaved more like spring wheat in it's ability to harden during autumn and therefore had very low winter survival (Table 1), it was excluded from further testing.

\section{Winter wheat}

The field survival of winter wheat varieties at different locations in 1989-1992 is shown in Table 1. The analysis of variance indicates that in some trials the differences between varieties were not significant (Table 1). In some cases this was due to a very mild winter period (Mietoinen 1992 and Jokioinen 1992), which caused only slight damage to the plants. Ice encasement at Anjalankoski 1991 resulted in very clear but uneven injury to the cultivars, but the differences between varieties were obscured by the great variation between replicates.

The ranges of variation within each trial are shown in Figure 2. Very significant positive correlations were found between all the trials in which there was a wide variation between varieties. This was obvious for Jokioinen 1991, Pälkäne 1990, Anjalankoski 1991, Laukaa 1990 and 1991 and Sotkamo 1990, 1991 and 1992. All these trials were characterized by cold winter with rather long period of snow cover, and they were pooled to form group 1. The results of this group correlated well also with all the results from Inter-Nordic trials and with the total results from Finnish trials (Table 2).

The group 2 trials were Mietoinen 1991, Pälkäne 1991, Anjalankoski 1990 and 1992 and Laukaa 

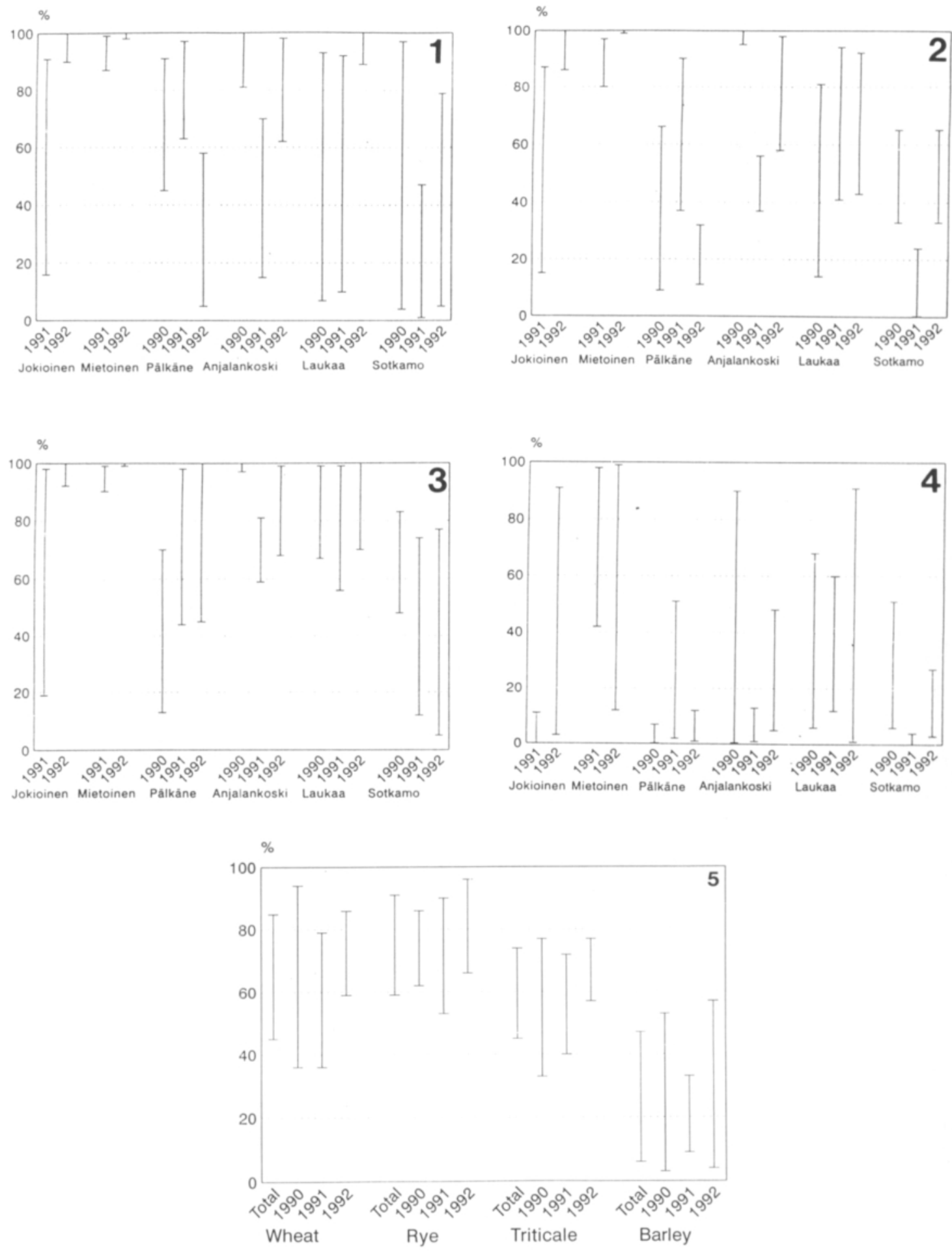

Fig. 2. Variation in winter survival ability of winter wheat (1), triticale (2), rye (3) and winter barley (4) varieties, and total variation of each species in each of the experimental years (5). Winter wheat variety 'Vitus' was excluded because it is similar in hardiness to spring wheats. 


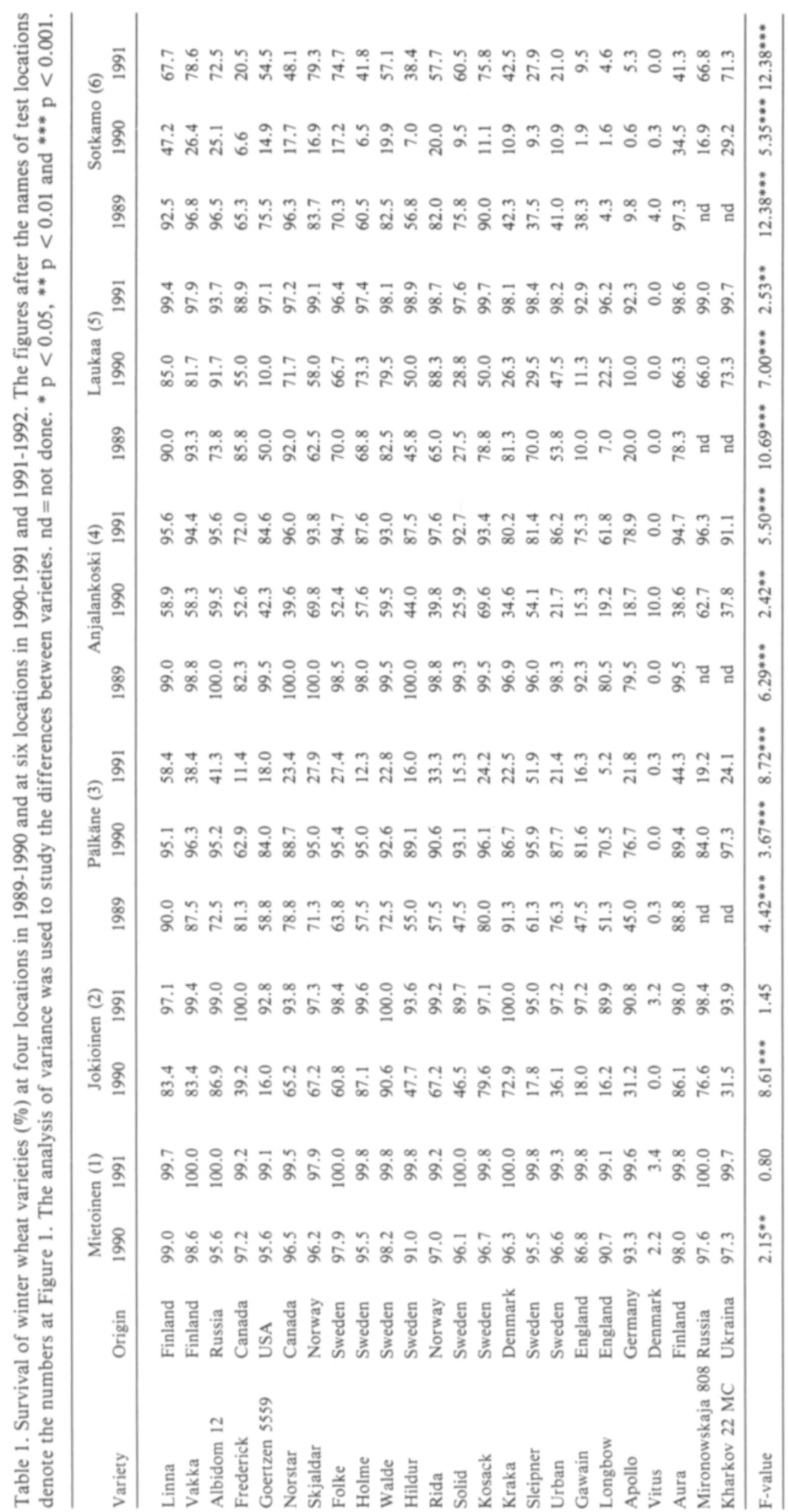


Table 2. Correlations between winter survival in the winter wheat, rye and winter barley trials, and mean winter survival in the Inter-Nordic (Total frost, Total snow, Total I-N) and Finnish trials in 1989-1992 and means of all trials. ${ }^{*} \mathrm{p}<0.05$, ${ }^{* *} \mathrm{p}<0.01{ }^{* * *} \mathrm{p}<0.001$.

\begin{tabular}{|c|c|c|c|c|c|c|c|c|}
\hline \multicolumn{2}{|c|}{ Winter wheat } & \multirow{2}{*}{$\begin{array}{l}\begin{array}{c}\text { Total } \\
\text { frost }\end{array} \\
0.63^{* * *}\end{array}$} & \multirow{2}{*}{$\begin{array}{c}\begin{array}{c}\text { Total } \\
\text { snow }\end{array} \\
0.82^{* * *}\end{array}$} & \multirow{2}{*}{$\begin{array}{c}\begin{array}{c}\text { Total } \\
\text { I-N }\end{array} \\
0.74^{* * *}\end{array}$} & \multirow{2}{*}{$\begin{array}{c}\begin{array}{c}\text { Finland } \\
1990\end{array} \\
0.79^{* * *}\end{array}$} & \multirow{2}{*}{$\begin{array}{c}\begin{array}{c}\text { Finland } \\
1991\end{array} \\
0.73^{* * *}\end{array}$} & \multirow{2}{*}{$\begin{array}{c}\begin{array}{c}\text { Finland } \\
1992\end{array} \\
0.71^{* * *}\end{array}$} & \multirow{2}{*}{$\begin{array}{c}\begin{array}{c}\text { Finland } \\
\text { total }\end{array} \\
0.77^{* * *}\end{array}$} \\
\hline Mietoinen & 1991 & & & & & & & \\
\hline & 1992 & 0.11 & 0.15 & 0.15 & 0.12 & 0.16 & 0.17 & 0.15 \\
\hline \multirow[t]{2}{*}{ Jokioinen } & 1991 & $0.83^{* * *}$ & $0.86^{* * *}$ & $0.86^{* * *}$ & $0.78^{* * *}$ & $0.89^{* * *}$ & $0.71^{* * *}$ & $0.83^{* * *}$ \\
\hline & 1992 & $0.54^{* *}$ & $0.61^{* *}$ & $0.59^{* *}$ & $0.63^{* *}$ & $0.61^{* *}$ & $0.41^{*}$ & $0.59^{* *}$ \\
\hline \multirow[t]{3}{*}{ Pălkăne } & 1990 & $0.65^{* * *}$ & $0.76^{* * *}$ & $0.71^{* * *}$ & $0.82^{* * *}$ & $0.62^{* *}$ & $0.55^{* *}$ & $0.71^{* * *}$ \\
\hline & 1991 & $0.55^{* *}$ & $0.66^{* * *}$ & $0.63^{* *}$ & $0.54^{*}$ & $0.64^{* * *}$ & $0.80^{* * *}$ & $0.67^{* * *}$ \\
\hline & 1992 & $0.62^{* *}$ & $0.62 * *$ & $0.64 * *$ & $0.54 * *$ & $0.54 * *$ & $0.68 * * *$ & $0.60^{* * *}$ \\
\hline \multirow[t]{3}{*}{ Anjalank. } & 1990 & $0.60^{* *}$ & $0.70^{* * *}$ & $0.67^{* * *}$ & $0.68^{* * *}$ & $0.64^{* *}$ & $0.79 * * *$ & $0.73^{* * *}$ \\
\hline & 1991 & $0.69^{* * *}$ & $0.76^{* * *}$ & $0.75^{* * *}$ & $0.72^{* * *}$ & $0.79 * * *$ & $0.69^{* * *}$ & $0.77^{* * *}$ \\
\hline & 1992 & $0.77 * * *$ & $0.82^{* * *}$ & $0.81^{* * *}$ & $0.75^{* * *}$ & $0.81^{* * *}$ & $0.91 * * *$ & $0.85^{* * *}$ \\
\hline \multirow[t]{3}{*}{ Laukaa } & 1990 & $0.76^{* * *}$ & $0.89^{* * *}$ & $0.84 * * *$ & $0.93^{* * *}$ & $0.81^{* * *}$ & $0.71 * * *$ & $0.87^{* * *}$ \\
\hline & 1991 & $0.85^{* * *}$ & $0.83^{* * *}$ & $0.85^{* * *}$ & $0.75^{* * *}$ & $0.91 * * *$ & $0.70^{* * *}$ & $0.84^{* * *}$ \\
\hline & 1992 & 0.36 & $0.44^{*}$ & 0.42 & 0.37 & $0.44^{*}$ & $0.59^{* *}$ & $0.47^{*}$ \\
\hline \multirow[t]{3}{*}{ Sotkamo } & 1990 & $0.87^{* * *}$ & $0.89 * * *$ & $0.89^{* * *}$ & $0.90^{* * *}$ & $0.83^{* * *}$ & $0.86^{* * *}$ & $0.90^{* * *}$ \\
\hline & 1991 & $0.86^{* * *}$ & $0.82^{* * *}$ & $0.85^{* * *}$ & $0.76^{* * *}$ & $0.75^{* * * *}$ & $0.79 * * *$ & $0.79 * * *$ \\
\hline & 1992 & $0.78^{* * *}$ & $0.82^{* * *}$ & $0.83^{* * *}$ & $0.75^{* * *}$ & $0.80^{* * *}$ & $0.91^{* * *}$ & $0.84^{* * *}$ \\
\hline \multicolumn{9}{|l|}{ Winter rye } \\
\hline \multirow[t]{2}{*}{ Mietoinen } & 1991 & 0.28 & $0.84^{* * *}$ & $0.70^{*}$ & $0.85^{* * *}$ & $0.63^{*}$ & $0.72^{* *}$ & $0.71^{* *}$ \\
\hline & 1992 & -0.13 & 0.44 & 0.28 & 0.35 & 0.32 & 0.52 & 0.42 \\
\hline \multirow[t]{2}{*}{ Jokioinen } & 1991 & $0.84^{* * *}$ & $0.82^{* * *}$ & $0.91 * * *$ & $0.71^{*}$ & $0.93 * * *$ & $0.86^{* * *}$ & $0.89^{* * *}$ \\
\hline & 1992 & -0.15 & 0.54 & 0.33 & 0.56 & 0.47 & 0.56 & 0.55 \\
\hline \multirow[t]{3}{*}{ Pălkăne } & 1990 & $0.70^{*}$ & $0.89 * * *$ & $0.90^{* * *}$ & $0.89^{* * *}$ & $0.90^{* * *}$ & $0.86^{* * *}$ & $0.91 * * *$ \\
\hline & 1991 & 0.55 & $0.93^{* * *}$ & $0.87^{* * *}$ & $0.90^{* * *}$ & $0.82 * * *$ & $0.86^{* * *}$ & $0.86^{* * * *}$ \\
\hline & 1992 & $0.89^{* * *}$ & $0.84^{* * *}$ & $0.93^{* * *}$ & $0.81^{* *}$ & $0.91 * * *$ & $0.86^{* * *}$ & $0.90^{* * *}$ \\
\hline \multirow[t]{3}{*}{ Anjalank. } & 1990 & -0.12 & 0.45 & 0.26 & 0.52 & 0.21 & 0.39 & 0.35 \\
\hline & 1991 & -0.41 & -0.18 & -0.30 & -0.05 & 0.17 & 0.24 & 0.22 \\
\hline & 1992 & 0.51 & $0.77^{* *}$ & $0.74^{* *}$ & $0.72 * *$ & $0.68^{* *}$ & $0.70^{* *}$ & $0.71 * *$ \\
\hline \multirow[t]{3}{*}{ Laukaa } & 1990 & -0.06 & 0.57 & 0.38 & $0.64^{*}$ & 0.33 & 0.50 & 0.48 \\
\hline & 1991 & $0.81^{* *}$ & $0.70^{*}$ & $0.79^{* *}$ & $0.79^{* *}$ & $0.77^{* *}$ & $0.63^{*}$ & $0.75^{* *}$ \\
\hline & 1992 & 0.20 & $0.73^{* *}$ & $0.60^{*}$ & $0.69^{*}$ & $0.64^{*}$ & $0.77^{* *}$ & $0.73^{* *}$ \\
\hline Sotkamo & 1990 & $0.65^{*}$ & $0.59^{*}$ & $0.64^{*}$ & $0.68^{*}$ & $0.66^{*}$ & 0.40 & $0.60^{*}$ \\
\hline & 1991 & $0.64^{*}$ & $0.90^{* * *}$ & $0.88^{* * *}$ & $0.76^{* *}$ & $0.77^{* *}$ & $0.69^{* *}$ & $0.73^{* *}$ \\
\hline & 1992 & 0.44 & $0.83^{* * *}$ & $0.76^{* *}$ & $0.61^{*}$ & $0.80^{* * *}$ & $0.90^{* * *}$ & $0.83^{* * *}$ \\
\hline Winter bar & & & & & & & & \\
\hline Mietoinen & 1991 & $0.67^{*}$ & $0.83^{* * *}$ & $0.81^{* *}$ & 0.54 & $0.83^{* * *}$ & $0.80^{* *}$ & $0.80^{* *}$ \\
\hline & 1992 & $0.61^{*}$ & $0.79 * *$ & $0.77^{* *}$ & 0.50 & $0.75^{* *}$ & $0.84^{* * *}$ & $0.78^{* *}$ \\
\hline Jokioinen & 1991 & 0.52 & $0.61^{*}$ & 0.58 & 0.54 & $0.65^{*}$ & 0.55 & $0.62^{*}$ \\
\hline & 1992 & $0.68^{*}$ & $0.85^{* * *}$ & $0.83^{* *}$ & 0.60 & $0.83^{* * *}$ & $0.94^{* * *}$ & $0.87^{* * *}$ \\
\hline Pălkāne & 1990 & $0.84^{* *}$ & $0.68^{*}$ & $0.74^{* *}$ & $0.78^{* *}$ & 0.50 & 0.57 & $0.67^{*}$ \\
\hline & 1991 & 0.57 & $0.61^{*}$ & $0.62^{*}$ & 0.45 & $0.80^{* * *}$ & $0.61^{*}$ & $0.66^{*}$ \\
\hline & 1992 & $0.61^{*}$ & $0.70^{*}$ & $0.70^{*}$ & 0.53 & $0.70^{*}$ & $0.75^{* *}$ & $0.71^{* *}$ \\
\hline Anjalank. & 1990 & $0.88^{* * *}$ & $0.88^{* * *}$ & $0.87^{* * *}$ & $0.97^{* * *}$ & $0.63^{*}$ & $0.72^{*}$ & $0.84^{* *}$ \\
\hline & 1991 & $0.80^{* *}$ & $0.86^{* * *}$ & $0.84^{* *}$ & $0.87 * * *$ & $0.65^{*}$ & 0.47 & $0.67^{*}$ \\
\hline & 1992 & 0.23 & 0.48 & 0.43 & 0.19 & $0.73^{* *}$ & $0.60^{*}$ & 0.55 \\
\hline Laukaa & 1990 & $0.78^{* *}$ & $0.78^{* *}$ & $0.77^{* *}$ & $0.88^{* * *}$ & 0.58 & $0.63^{*}$ & $0.75^{* *}$ \\
\hline & 1991 & 0.49 & 0.60 & 0.60 & 0.49 & $0.73^{* *}$ & $0.63^{*}$ & $0.66^{*}$ \\
\hline & 1992 & $0.82^{* *}$ & $0.84 * *$ & $0.82^{* *}$ & $0.94^{* * *}$ & 0.54 & $0.72^{* *}$ & $0.79 * *$ \\
\hline Sotkamo & 1990 & $0.83^{* *}$ & $0.84^{* *}$ & $0.83^{* *}$ & $0.89^{* * *}$ & $0.62^{*}$ & $0.74^{* *}$ & $0.81^{* *}$ \\
\hline & 1991 & 0.41 & 0.57 & 0.51 & 0.47 & $0.59^{*}$ & 0.34 & 0.49 \\
\hline & 1992 & $0.83^{* *}$ & $0.76^{* *}$ & $0.79^{* *}$ & $0.80^{* *}$ & 0.54 & $0.69^{*}$ & $0.70^{*}$ \\
\hline
\end{tabular}

Winter wheat $\mathrm{n}=21$ in Inter-Nordic trials and in 1990 trials, otherwise $\mathrm{n}=23$ rye $\mathrm{n}=11$ or $\mathrm{n}=13$ and winter barley $\mathrm{n}=10$ or $\mathrm{n}=11$, respectively. 
1992. All these trials were characterized by a relatively mild winter. The cold periods were quite short, and the minimum temperatures during the cold season were moderate. In most trials, some damage was caused by snow mould, but on average the survival rate of all the experimental varieties was high, and the variation between varieties was small. A significant positive correlation was found between the individual trials, and in most cases the results of these trials correlated also well with the total results of the Inter-Nordic trials and with the totals of the Finnish trials, but the level of correlation was not so high as in group 1. In both cases, the individual trials correlated better with the InterNordic trials when the stress factor was snow mould (Table 2). The analysis of variance showed significant differences between varieties in both groups. As expected the years and experimental sites differed from each other also very significantly (Table 3). Tukey's Studentized Range test was used to group the varieties on the basis of their winterhardiness (Table 4). In both groups, varieties with high and low winterhardiness could be identified, but the varieties with moderate winterhardiness could only be identified in severe winter conditions. On the basis of these results and the total means of winter survival (Table 4) the most winter hardy varieties were 'Linna', 'Vakka', 'Kosack', 'Albidom 12' and 'Aura', and those least winter hardy were 'Gawain', 'Apollo' and 'Longbow'. Three varieties were excluded from the analysis. Two varieties, 'Mironowskaja 808' and 'Kharkov 22 MC' were not included in the 1990 trials and were therefore excluded from the analysis. These two varieties are both considered to be moderately winter hardy. Since 'Vitus' is similar in hardiness to spring wheats, it was also excluded from the analysis.

The negative but not significant correlation between survival percentage and growth habit, and the highly significant positive correlation between amount of snow mould damage and erect growth habit of winter wheat varieties indicates that prostrate growth habit might be more beneficial for the winter survival of winter wheat (Table 5). There was a highly significant positive correlation between survival rate and size (both growth stage and
Table 3. Analysis of variance for the survival rate of winter wheat in groups 1 and 2, rye in groups 1 and 2, triticale in groups 1 and 2 and winter barley in groups 1, 2 and 3. ${ }^{*} \mathrm{p}<0.05,{ }^{* *} \mathrm{p}<0.01,{ }^{* * *} \mathrm{p}<0.001$.

\begin{tabular}{lrrr}
\hline Source of variation & DF & MS & F-value \\
\hline Winter wheat & & & \\
Group 1. & & & \\
Variety & 20 & 1.70 & $24.29^{* * *}$ \\
Location & 4 & 1.90 & $27.14^{* * *}$ \\
Year & 2 & 6.06 & $86.57^{* * *}$ \\
Error & 616 & 0.07 & \\
Group 2. & & & \\
Variety & 20 & 0.19 & $9.50^{* * *}$ \\
Location & 3 & 0.46 & $23.00^{* * *}$ \\
Year & 1 & 1.87 & $93.50^{* * *}$ \\
Error & 395 & 0.02 &
\end{tabular}

Winter rye

Group 1.

Variety

Location

Year

Error

$26.20 * * *$ $111.80^{* * *}$ $86.60^{* * *}$

Group 2,

Variety

Location

Year

Error

0.14

0.75

0.40

0.02

Winter triticale

Group 1.

Variety

Location

Year

Error

0.53

$17.67^{* * *}$ $225.00^{* * *}$ $109.33^{* * *}$

Group 2.

Variety

Location

0.72

$10.29^{* * *}$

0.69

$9.86 * * *$

Error

0.07

W'inter barley

Group 1.

Variety

Location

Year

Error

0.84

$21.00^{* * * *}$

$39.75 * * *$

$32.75^{* * *}$

1.31

0.04

Group 2.

Variety

Location

Year

Error

0.21

$21.00^{* * *}$

$90.00^{* * *}$

$59.00^{* * *}$

Group 3.

Variety

Location

Year

Error

0.59

0.01

0.21

$21.00^{* * *}$

0.90

$90.00 * * *$

$59.00^{* * *}$

0.01 
Table 4. Winter survival of winter wheat, rye and winter barley varieties. Means are total means of field trials in 1989-1992 at six locations. The grouping of varieties is based on Tukey's Studentized Range test. ni $=$ not included.

\begin{tabular}{|c|c|c|c|c|}
\hline Winter wheat & Mean & Grouping & & Grouping \\
\hline Group 1 & & & Group 2 & \\
\hline Vakka & 83.5 & $\mathbf{a}$ & Linna & a \\
\hline Linna & 85.2 & a & Kosack & $a b$ \\
\hline Kosack & 79.0 & $a b c$ & Folke & $a b$ \\
\hline Albidom 12 & 81.3 & $a b c$ & Vakka & $a b$ \\
\hline Aura & 79.4 & $a b c$ & Skjaldar & $a b$ \\
\hline Walde & 77.8 & abcd & Rida & $a b$ \\
\hline Norstar & 77.0 & abcd & Aura & $a b$ \\
\hline Skjaldar & 76.3 & abcd & Walde & $a b$ \\
\hline Folke & 74.1 & bcde & Norstar & $a b$ \\
\hline Rida & 74.3 & bcde & Albidom 12 & $a b$ \\
\hline Holme & 71.1 & bcdef & Solid & $a b$ \\
\hline Kraka & 67.6 & bcdefg & Holme & $a b$ \\
\hline Goertzen 5559 & 63.1 & bcdefg & Sleipner & $a b$ \\
\hline Solid & 62.8 & bcdefg & Hildur & $a b$ \\
\hline Frederick & 64.1 & bcdefg & Urban & $a b c$ \\
\hline Hildur & 64.3 & bcdefg & Goertzen 5559 & $a b c$ \\
\hline Sleipner & 64.0 & cdefg & Kraka & bc \\
\hline Urban & 62.1 & defg & Gawain & cd \\
\hline Gawain & 49.6 & h & Apollo & d \\
\hline Apollo & 48.3 & $\mathrm{~h}$ & Frederick & d \\
\hline Longbow & 45.0 & $\mathrm{~h}$ & Longbow & d \\
\hline Vitus & $1.4 \mathrm{ni}$ & & & \\
\hline Mironovsk. 808 & $73.7 \mathrm{ni}$ & & & \\
\hline Kharkov & $71.3 \mathrm{ni}$ & & & \\
\hline \multicolumn{5}{|l|}{ Rye } \\
\hline Group 1 & & & Group 2 & \\
\hline Jussi & 90.5 & $a b c$ & Jussi & $a b c$ \\
\hline Voima & 89.0 & $\mathrm{abc}$ & Anna & $a b c$ \\
\hline Anna & 87.0 & abcd & Norderåstetra & $a b c$ \\
\hline Norderåstetra & 84.7 & abcde & Talovskaja 12 & abcd \\
\hline Talovskaja 12 & 82.8 & bcde & Voima & abcd \\
\hline Vàgonäs hŏstråg & 75.6 & cdef & Petkus ii & abcde \\
\hline Prima & 71.4 & efgh & Prima & abcde \\
\hline Danko & 71.8 & fghi & Dominator & abcde \\
\hline Epos & 68.3 & fghij & Danko & bcde \\
\hline Dominator & 71.2 & fghij & Kungs ii & cde \\
\hline Kungs ii & 67.3 & fghij & Musketeer & cdef \\
\hline Petkus ii & 69.0 & ghij & Epos & cdef \\
\hline Musketeer & 59.5 & hij & Vàgonäs höstrág & ef \\
\hline \multicolumn{5}{|l|}{ Winter barley } \\
\hline Group 1 & & & Group 3 & \\
\hline Borwina & 46.7 & $\mathrm{a}$ & WB $158-25$ & $a b$ \\
\hline Andrea & 38.5 & b & Andrea & $a b$ \\
\hline Frost & 37.9 & b & Borwina & $a b c$ \\
\hline Marinka & 32.9 & $\mathrm{~cd}$ & Marinka & $a b c$ \\
\hline Lady & 28.2 & $\mathrm{~cd}$ & Frost & $a b c$ \\
\hline Trixi & 30.0 & $\mathrm{~cd}$ & Trixi & $a b c$ \\
\hline OAC Acton & 24.7 & $\mathrm{~cd}$ & Finesse & $a b c$ \\
\hline Finesse & 29.7 & cd & Lady & $a b c$ \\
\hline Igri & 24.2 & cd & OAC Acton & $a b c$ \\
\hline WB 158-25 & 26.0 & cde & Igri & $b c$ \\
\hline Maris Otter & 5.9 & de & Maris Otter & d \\
\hline
\end{tabular}


Table 5. Correlations between winter survival of winter wheat, rye and triticale varieties, and snow mould damage, growth habit, growth stage (= number of leaves) and height of plants. ${ }^{*} \mathrm{p}<0.05,{ }^{* *} \mathrm{p}<0.01$ and ${ }^{* * *} \mathrm{p}<0.001$.

\begin{tabular}{|c|c|c|c|c|}
\hline & Snow mould & Growth habit & Growth stage & Plant height \\
\hline \multicolumn{5}{|l|}{ Winter wheat: } \\
\hline Survival \% & $\begin{array}{r}-0.51^{* * *} \\
\mathrm{n}=898\end{array}$ & $\begin{array}{l}-0.24 \\
n=40\end{array}$ & $\begin{array}{l}0.56^{* * *} \\
\mathrm{n}=40\end{array}$ & $\begin{array}{l}0.54^{* * *} \\
\mathrm{n}=40\end{array}$ \\
\hline Snow mould & & $\begin{array}{l}0.53^{* * *} \\
\mathrm{n}=40\end{array}$ & $\begin{array}{l}-0.06 \\
\mathrm{n}=40\end{array}$ & $\begin{array}{l}-0.01 \\
n=40\end{array}$ \\
\hline \multicolumn{5}{|l|}{ Winter rye: } \\
\hline Survival \% & $\begin{array}{r}-0.21 * * * \\
\mathrm{n}=560\end{array}$ & $\begin{array}{l}0.51^{* *} \\
\mathrm{n}=25\end{array}$ & $\begin{array}{l}0.17 \\
\mathrm{n}=25\end{array}$ & $\begin{array}{l}0.43^{*} \\
\mathrm{n}=25\end{array}$ \\
\hline Snow mould & & $\begin{array}{l}-0.07 \\
n=25\end{array}$ & $\begin{array}{l}-0.34 \\
n=25\end{array}$ & $\begin{array}{l}-0.42^{*} \\
\mathrm{n}=25\end{array}$ \\
\hline \multicolumn{5}{|l|}{ Triticale: } \\
\hline Survival \% & $\begin{array}{r}-0.60 * * * \\
\mathrm{n}=210\end{array}$ & $\begin{array}{l}-0.23 \\
n=10\end{array}$ & $\begin{array}{l}0.51 \\
\mathrm{n}=10\end{array}$ & $\begin{array}{l}0.31 \\
\mathrm{n}=10\end{array}$ \\
\hline Snow mould & & $\begin{array}{l}0.27 \\
\mathrm{n}=10\end{array}$ & $\begin{array}{l}-0.29 \\
\mathrm{n}=10\end{array}$ & $\begin{array}{l}-0.25 \\
\mathrm{n}=10\end{array}$ \\
\hline
\end{tabular}

height of the plants) of the wheat varieties (Table 5). Thus the robust plants which synthesize more reserves during the autumn survive better.

The amount of damage to varieties in different trials caused by snow mould (Microdochium nivale) is shown in Table 6. On the basis of analysis of variance the differences in snow mould resistance between winter wheat varieties were significant only in five trials out of twelve (Table 6). On the basis of the total means of the two years, the most snow mould resistant winter wheat varieties were 'Linna', 'Folke', 'Sleipner', 'Aura' and 'Vakka' and those most susceptible were 'Longbow', 'Frederick', 'Apollo', 'Gawain' and 'Goertzen 5559 '. There was a highly significant negative correlation betweeen winter survival and snow mould injury (Table 5). Thus varieties with poor overwintering capacity were also susceptible to snow mould.

\section{Winter rye}

The winter survival rates of winter rye and triticale varieties at different locations in 1989-1992 are shown in Table 7. The analysis of variance indicated that in some trials the differences be- tween varieties were not significant (Table 7). In most cases this was due to a very mild winter (Mietoinen 1992, Jokioinen 1992 and Anjalankoski 1990).

The range of variation within winter rye trials is shown in Figure 2. The trials were separated into two groups based on the degree of variation. In group 1 there was extensive variation between the varieties, while in group 2 the variation was limited. There was in most cases a highly significant correlation between the results of trials within each group. In group 1 there was extensive variation between the varieties at Jokioinen 1991, Pälkäne 1990, 1991 and 1992, Anjalankoski 1992, Laukaa 1991 and Sotkamo 1991 and 1992. All these trials had a cold winter and prolonged snow cover. In trials at Jokioinen 1992, Mietoinen 1991 and 1992, Anjalankoski 1990 and Laukaa 1990 and 1992 there was only small variation between the rye varieties, and these trials made up group 2 . These trials were characterized by a rather mild winters. There was in most cases a high positive correlation between the results of group 1 trials, the total results of Finnish trials and the results of the Inter-Nordic trials, especially when the primary stress factor was snow (Table 2). In group 2 trials, the correlations with the Inter-Nordic trials and the Finnish totals 
Table 6. Snow mould (M.nivale) resistance of winter wheat, rye and triticale in 1990-1991 and 1991-1992 at different locations. A scoring system of 0 (no damage) to 10 (dead plant) was used. The differences between varieties were studied with the analysis of variance. ${ }^{*} \mathrm{p}<0.05,{ }^{* *} \mathrm{p}<0.01$ and ${ }^{* * *} \mathrm{p}<0.001$.

Winter wheat

\begin{tabular}{|c|c|c|c|c|c|c|c|c|}
\hline \multirow[t]{2}{*}{ Variety } & \multirow{2}{*}{$\begin{array}{c}\text { Mietoinen (1) } \\
1990\end{array}$} & \multicolumn{2}{|c|}{ Jokioinen (2) } & \multicolumn{2}{|c|}{ Pälkäne (3) } & \multicolumn{2}{|c|}{ Laukaa (5) } & \multirow{2}{*}{$\begin{array}{c}\text { Sotkamo (6) } \\
1990\end{array}$} \\
\hline & & 1990 & 1991 & 1990 & 1991 & 1990 & 1991 & \\
\hline Linna & 0.25 & 0.75 & 1.25 & 1.50 & 5.75 & 2.00 & 1.50 & 2.00 \\
\hline Vakka & 0.75 & 1.25 & 1.00 & 2.25 & 8.25 & 1.75 & 2.00 & 5.00 \\
\hline Albidom & 2.00 & 1.00 & 1.50 & 2.00 & 6.50 & 2.00 & 3.00 & 5.00 \\
\hline Aura & 1.00 & 1.50 & 1.75 & 2.00 & 7.50 & 2.50 & 2.75 & 3.00 \\
\hline Kosack & 1.00 & 0.50 & 1.50 & 1.75 & 9.25 & 3.00 & 1.75 & 4.25 \\
\hline Walde & 1.00 & 2.50 & 1.75 & 3.25 & 8.75 & 1.50 & 2.00 & 3.25 \\
\hline Kharkow & 1.50 & 3.00 & 1.25 & 1.50 & 9.00 & 3.75 & 1.25 & 3.00 \\
\hline Miron. 808 & 0.75 & 3.25 & 1.00 & 3.25 & 9.25 & 3.25 & 1.75 & 4.50 \\
\hline Norstar & 1.25 & 0.75 & 1.50 & 3.25 & 8.75 & 5.00 & 3.25 & 5.50 \\
\hline Skjaldar & 1.75 & 2.50 & 0.50 & 3.00 & 6.25 & 4.25 & 1.25 & 5.25 \\
\hline Rida & 1.75 & 2.50 & 1.75 & 3.75 & 7.75 & 3.50 & 2.50 & 2.75 \\
\hline Folke & 1.25 & 1.25 & 1.25 & 0.50 & 7.75 & 2.75 & 1.00 & 2.50 \\
\hline Holme & 1.50 & 2.25 & 1.75 & 2.25 & 9.75 & 2.00 & 2.50 & 4.25 \\
\hline Hildur & 2.00 & 3.75 & 1.50 & 2.50 & 9.75 & 5.25 & 2.00 & 4.25 \\
\hline Kraka & 1.75 & 2.75 & 2.00 & 2.75 & 9.00 & 5.75 & 2.25 & 3.75 \\
\hline Sleipner & 1.25 & 1.00 & 1.25 & 2.25 & 3.25 & 5.00 & 2.00 & 2.25 \\
\hline Frederick & 2.00 & 5.00 & 2.00 & 3.67 & 9.50 & 3.50 & 4.50 & 5.50 \\
\hline Solid & 1.25 & 2.50 & 1.25 & 1.75 & 8.75 & 5.75 & 1.75 & 3.50 \\
\hline Goertzen & 1.50 & 4.25 & 1.50 & 3.25 & 9.75 & 7.75 & 2.50 & 6.50 \\
\hline Urban & 1.50 & 2.50 & 2.75 & 2.50 & 8.25 & 4.00 & 2.25 & 4.25 \\
\hline Gawain & 4.25 & 2.25 & 3.00 & 3.75 & 9.50 & 5.00 & 4.25 & 4.75 \\
\hline Apollo & 2.75 & 3.00 & 1.50 & 3.67 & 8.75 & 6.50 & 4.25 & 6.33 \\
\hline Longbow & 2.50 & 1.25 & 1.50 & 3.50 & 10.00 & 5.75 & 3.75 & 7.00 \\
\hline F-value & $3.05^{* * *}$ & $3.47^{* * *}$ & $2.10^{* * *}$ & 1.81 & $8.62^{* * *}$ & 1.63 & $2.77^{* * *}$ & 0.86 \\
\hline
\end{tabular}

Rye and triticale

\begin{tabular}{|c|c|c|c|c|c|c|c|c|c|c|}
\hline \multirow[t]{2}{*}{ Variety } & \multirow{2}{*}{$\begin{array}{c}\text { Mietoinen (1) } \\
1990\end{array}$} & \multicolumn{2}{|c|}{ Jokioinen (2) } & \multicolumn{2}{|c|}{ Pälkäne (3) } & \multirow{2}{*}{$\begin{array}{c}\text { Anjala (4) } \\
1990\end{array}$} & \multicolumn{2}{|c|}{ Laukaa (5) } & \multicolumn{2}{|c|}{ Sotkamo (6) } \\
\hline & & 1990 & 1991 & 1990 & 1991 & & 1990 & 1991 & 1990 & 1991 \\
\hline Jussi & 0.50 & 4.25 & 1.75 & 3.00 & 1.25 & 0.25 & 4.25 & 1.50 & 1.00 & 0.00 \\
\hline Voima & 0.50 & 5.00 & 2.00 & 5.00 & 1.25 & 1.25 & 2.50 & 1.75 & 1.25 & 1.00 \\
\hline Anna & 0.75 & 5.25 & 2.00 & 4.25 & 1.50 & 0.75 & 3.00 & 2.25 & 2.50 & 1.50 \\
\hline Norderås tetra & 0.50 & 3.25 & 1.75 & 4.00 & 1.00 & 0.50 & 3.00 & 2.25 & 2.75 & 0.50 \\
\hline Vågonăs höstråg & 2.75 & 1.75 & 3.25 & 2.75 & 2.25 & 1.00 & 0.50 & 7.25 & 3.00 & 5.50 \\
\hline Talovskaja & 1.00 & 5.25 & 1.50 & 5.00 & 1.75 & 0.50 & 1.75 & 1.50 & 3.50 & 0.50 \\
\hline Musketeer & 3.00 & 7.50 & 1.00 & 4.67 & 6.00 & 1.50 & 1.75 & 3.25 & 1.75 & 0.00 \\
\hline Prima & 2.75 & 6.75 & 1.00 & 4.25 & 4.50 & 1.00 & 1.00 & 2.75 & 5.00 & 0.00 \\
\hline Dominator & 2.25 & 5.75 & 4.25 & 4.00 & 7.50 & 1.75 & 2.50 & 6.00 & 1.00 & 0.50 \\
\hline Kungs II & 2.50 & 7.25 & 4.75 & 3.25 & 7.00 & 0.75 & 3.50 & 5.50 & 3.25 & 1.50 \\
\hline Petkus II & 2.25 & 6.25 & 2.75 & 4.33 & 6.75 & 1.50 & 2.25 & 3.50 & 5.00 & 0.00 \\
\hline Epos & 2.00 & 5.50 & 3.50 & 3.67 & 7.00 & 0.75 & 3.50 & 3.25 & 2.75 & 1.00 \\
\hline Danko & 2.00 & 5.75 & 2.75 & 2.50 & 7.00 & 1.25 & 2.25 & 5.00 & 3.00 & 1.25 \\
\hline F-value & $7.24 * * *$ & $4.80^{* * *}$ & $2.71^{* *}$ & 0.99 & $27.06 * * *$ & 1.08 & $3.34^{* *}$ & $6.63^{* * *}$ & 1.63 & $6.30 * * *$ \\
\hline Sv 856003 & 1.50 & 1.75 & 1.25 & 1.25 & 8.75 & 3.75 & 1.50 & 2.25 & 1.50 & 0.50 \\
\hline Sj 868013 & 1.75 & 2.25 & 1.25 & - & 8.50 & 5.50 & 1.50 & 3.75 & 4.50 & 0.25 \\
\hline Dagro & 1.75 & 3.00 & 1.25 & - & 9.25 & 3.25 & 1.00 & 3.50 & 4.50 & 0.25 \\
\hline Uno & 2.50 & 2.50 & 1.00 & 0.50 & 9.00 & 3.40 & 0.00 & 2.75 & 4.50 & 1.50 \\
\hline Local & 2.75 & 7.50 & 1.75 & 2.25 & 8.75 & 7.75 & 0.25 & 7.25 & 6.25 & 1.50 \\
\hline F-value & 1.72 & $28.47^{* * *}$ & 0.30 & $4.27^{*}$ & 0.67 & 1.36 & $3.34^{*}$ & $8.28^{* * *}$ & 1.68 & $1.52 * * *$ \\
\hline
\end{tabular}




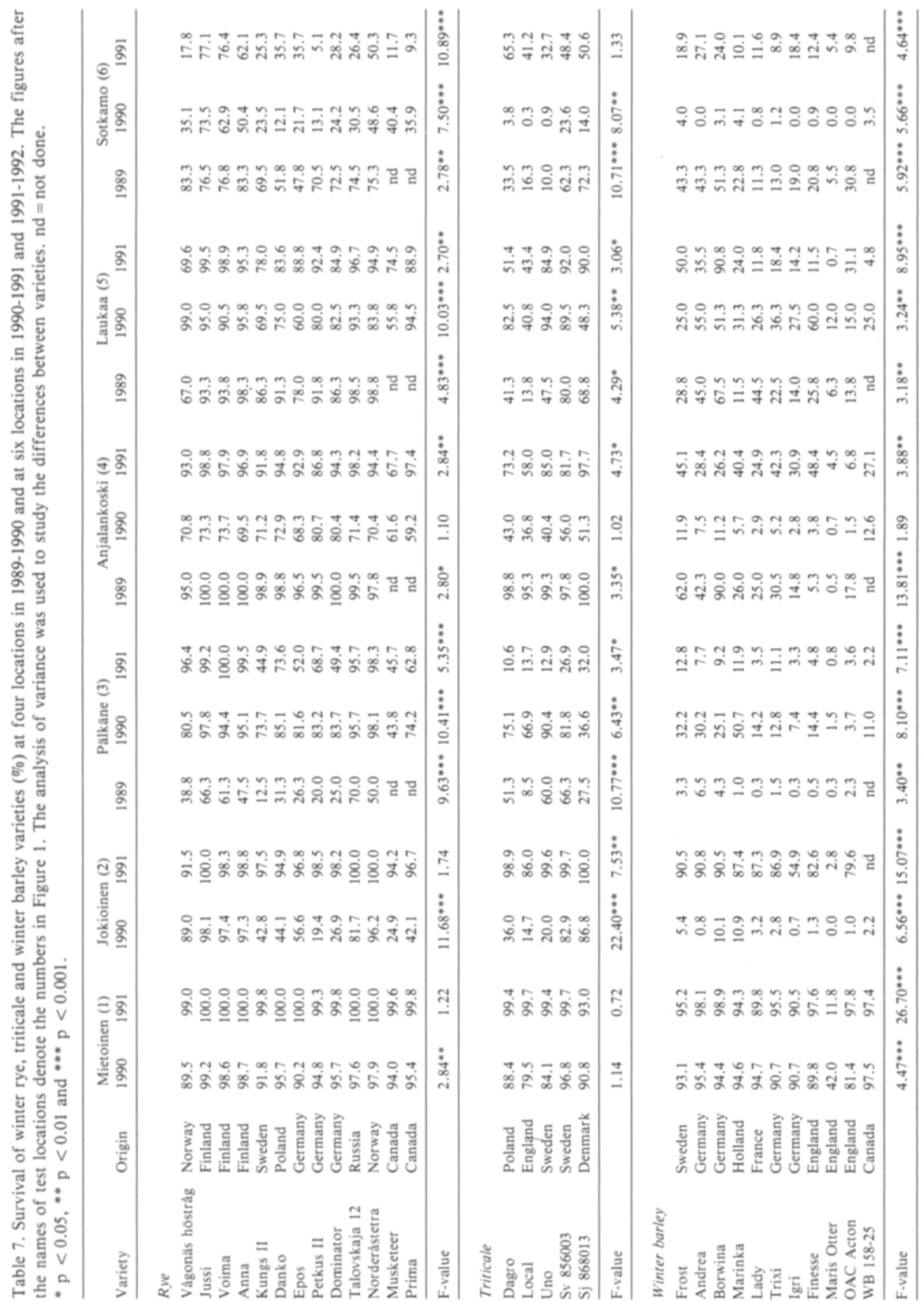


were mostly non significant. However, the results of the trials Jokioinen 1992, Mietoinen 1991 and Laukaa 1992 correlated positively with the totals of both the Inter-Nordic and the Finnish trials. The analysis of variance indicated that the differences between the experimental varieties were highly significant for both groups. The differences between the experimental sites and years were also highly significant during the test period (Table 3 ). The rye varieties were classified according to their winterhardiness within both groups on the basis of Tukey's Studentized Range test (Table 4). The classification in group 1 was quite analogous with the winterhardiness of varieties based on the total means of the Finnish trials. According to this grouping, the most winter hardy rye varieties were 'Jussi', 'Voima', 'Anna' and 'Norderåstetra' and those most susceptible were 'Petkus II' and 'Musketeer'. In group 2 with quite mild winters, the order of hardiness of the varieties was somewhat different from that of group 1. For example, 'Vågonäs höstråg' survived better cold and snowy winters than the mild ones. In the case of 'Petkus II', the situation was the opposite. Since the differences in winterhardiness of varieties were very small in group 2, the order of varieties in this group may be due to chance.

There was a positive correlation between winter survival and erect growth habit of winter rye varieties (Table 5). On average the growth habit of the rye varieties was more erect compared to the wheat varieties. At the end of the hardening period there was very little variation in the growth stage and height of plants among rye varieties. This was probably the reason for the lack of correlation between these factors and the winter survival of the varieties (Table 5). The correlation between growth stage and plant height and the snow mould damage to plants was also non significant, but negative as expected (Table 5).

The differences in snow mould ( $M$. nivale) damage among rye varieties were statistically significant in seven out of twelve trials (Table 6). There was a high negative correlation between the survival rate and snow mould injury in winter rye varieties (Table 5), indicating the importance of snow mould.

\section{Triticale}

The differences in the winter survival among triticale varieties were significant in seven out of 16 trials (Table 7). The ranges of variation within trials are shown in Figure 2. Although in some trials the winterhardiness of the most winter hardy triticale varieties was equal to that of the best winter wheat and rye varieties, the general winterhardiness of triticale varieties was similar to the medium or poorly winter hardy wheats (Fig. 2).

The results from trials with small variation in winter survival ability, either high survival (Jokioinen 1992, Mietoinen 1991 and 1992) or low survival (Pälkäne 1992, Anjalankoski 1991 and Sotkamo 1991 and 1992), correlated well with each other, and these trials made up group 1 . Since the results from Laukaa 1990 correlated well with these results, they were also included in group 1 .

There was also good correlation between trials with great variation in the survival abilities of varieties: Jokioinen 1991, Pälkäne 1990 and Laukaa 1991. These made up group 2.

The analysis of variance indicated that the differences in the survival rate among the varieties were highly significant in both groups (Table 3 ). The experimental sites, in group 1 also experimental years, differed from each other highly significantly, too. The most winter hardy triticale varieties were 'Sv 856003' and 'Sj 868013' and the least hardy was 'Local' (Table 4).

The correlations between the individual trials and Inter-Nordic trials could not be determined since triticale was excluded from the total InterNordic results.

The negative correlation between survival percentage and growth habit of triticale varieties indicates that prostrate growth habit might be beneficial for triticale as it was for winter wheat (Table 5). Positive but non significant correlations were observed between survival rate and growth stage and height of plants (Table 5).

There was a highly significant negative correlation between survival rate and snow mould resistance of triticale varieties (Table 5). The analysis of variance indicated that differences in snow mould resistance were significant only at Jokioinen 1991 
and at Laukaa 1992 (Table 6). The most snow mould resistant variety was 'Sv 856003' and the most susceptible was 'Local'.

\section{Winter barley}

The differences in the survival rates among winter barley varieties at different experimental sites in 1989-1992 are shown in Table 7. Three groups of winter barley trials could be formed based on the variation between varieties within trials (Fig. 2) and on the correlation between the results from different trials. Group 1 consisted of two trials (Pälkäne 1990 and Anjalankoski 1991), in which the survival percentage of all winter barley varieties was poor, and the variation between varieties was not significant (Table 7), and of five trials (Anjalankoski 1990, Laukaa 1990 and 1992 and Sotkamo 1990 and 1992) in which winter survival varied greatly with significant differences between varieties. In group 2 (Jokioinen 1991, Pälkäne 1991 and 1992 and Sotkamo 1991), the winter survival of varieties was poor, but the differences between the varieties were significant (Table 7). In group 3 (Jokioinen 1992 and Mietoinen 1991 and 1992), the survival rate of varieties was high, but there were significant differences in the winterhardiness between varieties.

There was a high positive correlation between the results of group 1 and group 3 trials and those of the Inter-Nordic trials (Table 2). The correlation between group 2 trials and Inter-Nordic trials was in some cases significant. In group 1 trials, most of the winters were cold with a prolonged snow cover. The group 3 trials were characterized by very mild winters, and most of the winter barley varieties survived very well. There were highly significant differences in the survival abilities of winter barley varieties within each of the groups (Table 3). The differences between the experimental sites were highly significant within each group, and in groups 1 and 2 the years differed from each other significantly, too. According to Tukey's Studentized Range test (Table 4), the most winter hardy barley varieties were 'Borwina', 'Andrea', 'Frost' and 'Marinka'. The most susceptible variety in all groups was 'Maris Otter'.
Growth habit and growth stage were not determined, since all the winter barley varieties were similar in this respect. The growth habit of all varieties was totally prostrate.

The snow mould resistance of winter barley varieties was not determined, because the stands were severely injured during the winter.

\section{Discussion}

The ability to survive under field conditions is considered to be the ultimate indication of a cultivar's winterhardiness potential. There are, however, biotic (snow moulds) and abiotic (frost, heaving and desiccation, ice encasement, flooding) stress factors, which may cause winter injury. Finland being situated between the maritime and continental climatic zones, has highly variable weather conditions during winter. All stress factors may occur during winter at the same site. It is therefore difficult to ascertain the major reason for winter injury. In addition, it is not possible to observe the sequence of events during the winter beneath a snow cover. For example, during a winter thaw, melted water percolates through the snow and builds up the frozen ground. These conditions may form ice encasement when the water refreezes. Alternate freezing and thawing in spring may cause the ice layer to disappear before the thawing. The weakened and damaged plant parts are then readily attacked by snow moulds. In such situations it is very difficult to determine the primary reason for winter injury. This was observed also in the present study especially in the case of winter wheat.

The winter survival of winter wheat, rye, triticale and winter barley varieties varied depending on the test location and the year. Rye was the most winter hardy species, winter wheat was somewhat hardier than triticale, although in some trials the survival of the most winter hardy triticale varieties was equal to that of the best winter wheat and rye varieties. Winter barley was the least winter hardy species. This is in accordance with the results of ANDREWS et al. (1986), Cloutier et al. (1990), FOWLER and CARLES (1979), FOWLER and LIMIN (1987), HÖMMÖ (1992) and KolAR et al. (1991). Accord- 
ing to METCALF et al. (1970), the higher moisture content in winter barley crowns than in wheat, could affect the winter survival of the species. According to POMEROY et al. (1975), the reason for the lower overwintering potential of winter barley compared with winter wheat could be both the lower hardening and the lower rehardening capacity after repeated warm periods in winter.

There were significant differences in the weather conditions at different test locations during the test period. At the southern-most location, Mietoinen, the test winters were very mild, and there was some winter damage only to the least winter hardy winter wheat, triticale and winter barley cultivars.

In 1989-1990, trials were established only at four locations: Pälkäne, Anjalankoski, Laukaa and Sotkamo. At all locations the cold period was short, but the minimum air temperatures were low $\left(-18^{\circ} \mathrm{C}\right.$ $\left.-24^{\circ} \mathrm{C}\right)$. At Pälkäne, the ground was unfrozen at the time of the first snowfall, which created favourable conditions for snow mould infection. The great variation in the survival of winter rye and triticale varieties was obviously due to the damage caused by snow mould although it was not specified. At Anjalankoski, the winter was very mild, and only the winter barley varieties were damaged. At Laukaa and Sotkamo, the winter conditions favoured screening for winterhardiness. The cold period was long enough to cause damage to plants, and the snow cover gave protection against extreme temperatures.

The winter 1990-1991 was the most appropriate for screening cultivars under field conditions. The differences in winter survival among the varieties were significant at all locations but Mietoinen and Anjalankoski. The primary cause of damage to plants was, however, in most cases obscure. Snow mould occurred at all locations, but the differences between varieties for snow mould resistance were significant only at Jokioinen, Mietoinen (wheat, rye) and Laukaa (rye).

The winter 1991-1992 was quite mild at all test locations. The minimum temperatures were moderate and the continuous frost period was short, but the snow cover was deeper than average at Pälkäne and Laukaa. At Pälkäne, winter wheat and winter barley varieties were injured by ice. At Laukaa, ice formation did not occur, as the snow melted simultaneously with the warming up of the weather. However, the mild winter combined with the thick snow cover promoted intensive snow mould infection primarily to the rye and triticale varieties.

The individual trials, which produced similar results, were pooled to form larger entities for analysis of variance. In all species the differences between varieties within these groups were statistically very significant. The test locations and the years differed from each other also significantly. It is probable that in each trial different combinations of stress factors prevailed, and the varieties were ranked according to their tolerance to the dominant stress factor(s) in each trial. Thus the results of field trials always characterize rather the general winter survival ability of varieties than the resistance to some specific stress factor. Accordingly, STEPONKUS (1978) and VEISZ and RAJKI (1987) stated that the frost resistance of winter wheat cannot be evaluated under field conditions in countries where the weather in winter is variable, even in the case of trials performed under extreme conditions.

The genetic controll of winterhardiness is complicated, making the breeding of winter hardy cultivars for all different winter stress conditions difficult. According to BRULE-BABEL and FOWLER (1988) and SUTKA (1981), the coldhardiness of winter wheat is mainly controlled by additive gene action with possibly by some dominant genes. GUL LORD (1974) divided frost resistance of winter wheat into high and low intensity freezing resistance, and stated that both are controlled by partially dominant genes which are mainly additive. FEDUlov et al. (1990) found also that the frost resistance of winter wheat is under polygenic control, but wheat varieties differ in their gene action, promoting frost resistance in the course of winter. Genetic control of coldhardiness is mainly additive also in rye (BRULE-BABEL and FOWLER 1989) and winter barley (EUNUS et al. 1962, ROHDE and PULHAM 1960),

According to BRUEHL (1982), the resistance to snow moulds is polygenic and non specific. ANDREWS and POMEROY (1975) and McKeRSIE and HUNT (1987) found a close correlation between the frost tolerance and ice encasement tolerance of 
winter wheat varieties, but in both studies there were clear exceptions. A similar correlation was observed also in winter wheat by ANDREWS and GUDLEIFSSON (1983). According to GUDLEIFSSON and LARSEN (1993), winter rye has the highest ice encasement tolerance of the winter cereals followed by winter wheat and triticale, while winter barley was the least tolerant.

There was a very significant positive correlation between the results of most of the individual trials and the results of the Inter-Nordic trials, especially those with snow being the main stress factor. This was obviously due to the fact that the snow results were mostly based on the Finnish trials, whereas the frost results were collected from the other Nordic countries. But another explanation might be that the ranking of varieties is different under frost and snow stress conditions, and that in Finland breeding against snow conditions is more important.

The prostrate growth habit was found to be more beneficial for the winter survival of winter wheat and triticale, and the erect growth habit was more beneficial for rye. The erect winter wheat and triticale plants are probably easily damaged by e.g. frost, and the damaged plant parts are readily attacked by snow mould. Since the leaves of winter rye plants are more hardy, it is not so important for rye to grow under protective snow cover. On the other hand, the attack of snow mould is better avoided if the leaves grow upwards and not along the ground. These results are in accordance with the results of FOWLER and CARLES (1979), FOWLER et al. (1981) and ROBERTS (1990).

On the basis of the results in this study, the screening for general winterhardiness of cereals should be done in quite extreme conditions. Mietoinen and Jokioinen were best suited for the selection of winter barley, and Laukaa and Sotkamo for winter wheat, rye and triticale. The most winter hardy winter wheat varieties were 'Linna', 'Vakka', 'Kosack', 'Albidom 12' and 'Aura', the most hardy rye varieties 'Jussi', 'Voima', 'Anna' and 'Norderåstetra', and the most hardy triticales 'Sv 856003 ' and 'Sj 868013'. The most winter hardy barley varieties were 'Borwina', 'Andrea' and 'Frost'.

The winterhardiness of overwintering plants is, however, always a very complicated matter depending on the hardening conditions, e.g. temperature and light, and the prevailing stress factors during winter. In addition, the ranking of varieties on the basis of results from one location may be quite different from that of another location. For example, the winter wheat variety 'Linna', developed in Finland, is the most winter hardy winter wheat variety in Finland. However, when grown in eastern Ontario, Canada, the winterhardiness of this variety was only moderate (ANDREWS et al. 1986). Thus one should be very careful in adopting breeding materials and test methods based on local conditions.

Acknowledgements. Sincere thanks are due to Miss MarjaLeena Manninen, Miss Pia Kallio and Mr. Yrjö Karppinen for their technical assistance as well as to the people at the experimental stations who helped in the practical work, and Mrs. Sevastiana Ruusamo for correcting the English language. This study was supported financially by the SNP (Samnordic Planteforedling) and the Ministry of Agriculture and Forestry.

\section{References}

ANDERSEN, I. L. 1992. Winter injuries in grasslands in northern Norway caused by low temperature fungi. Norwegian J. Agric. Sci. 7 (Suppl.): 13-20.

ANDERSSON, S. 1986. Skördetidens och kvävegödslingens inverkan på vallens övervintring. NJF Seminar Nr. 84, Lantbruksväxternas Övervintring. Jokioinen, Finland. p. 34-40.

AndREWs, C. J. \& Gudleifsson, B. E. 1983. A comparison of cold hardiness and ice encasement tolerance of timothy grass and winter wheat. Can. J. Plant Sci. 63: 429-435.
— \& Pomeroy, M. K. 1975. Survival and cold hardiness of winter wheats during partial and total ice immersion. Crop Sci. 15: 561-566.

—, Pomeroy, M. K. \& Seaman, W. L. 1986. The response of fallsown cereals to winter stresses in eastern Ontario. Can. J. Plant Sci. 66: 25-37.

Bengtsson, A. 1986. Såtider och benomylbehandling i höstråg och höstvete. NJF Seminar Nr. 84, Lantbruksväxternas Övervintring. Jokioinen, Finland. p. 4044. 
BrueHL, G. W. 1982. Developing wheats resistant to snow mold in Washington State. Plant Disease 66: 1090-1095.

Brule-BABel, A. L. \& Fowler, D. B. 1987. Genetic control of cold hardiness in winter wheat. Can. J. Plant Sci. 67: 276.

— \& FowLER, D. B. 1988. Genetic control of cold hardiness and vernalization requirement in winter wheat. Crop Sci. 28: 879-884.

— \& Fowler, D. B. 1989. Genetic control of cold hardiness and vernalization requirement in rye. Genome. 32: 19-23.

Cloutier, Y., Comeau, A., Bernier-Cardou, M. \& Angers, D. A. 1990. Effect of soil water content on the winter survival of winter wheat, rye and triticale. Can. J. Plant Sci. 70: 667-675.

DVoraK, J. \& Fowler, D. B. 1978. Cold hardiness potential of triticale and tetraploid rye. Crop Sci. 18: 477-478.

Eunus, A. M., Johnson, L. P. V. \& Aksel, R. 1962. Inheritance of winterhardiness in an eighteen-parent diallel cross of barley. Can. J. Genet. Cytol. 4: 356-376.

Fedulov, Yu. P., Puchion, Yu. M., Belikova, N. M. \& NaBakov, G. D. 1990. Change in structure of frost resistance of winter wheat during wintering. Soviet Agricultural Sciences (USA) 6: 1-4.

Fowler, D. B. \& CARles, R. J. 1979. Growth, development, and cold tolerance of fall-acclimated cereal grains. Crop Sci. 19: 915-922.

-, Dvorak, J. \& Gusta, L. V. 1977. Comparative cold hardiness of several Triticum species and Secale cereale L.. Crop Sci. 17: 941-943.

— \& GustA, L. V. 1977. Influence of fall growth and development on cold tolerance of rye and wheat. Can. J. Plant Sci. 57: 751-755.

- , Gusta, L. V., Bowren, K. E., Crowle, W. L., Mal. LOUGh, E. D., McBean, D. S. \& McIver, R.N. 1976. Potential for winter wheat production in Saskatchewan. Can. J. Plant Sci. 56: 45-50.

— \& Limin, A. E. 1987. Exploitable genetic variability for cold tolerance in commercially grown cereals. Can. J. Plant Sci. 67: 278.

Gudleirsson, B. E. 1986. Ice encasement damages on grasses and winter cereals. NJF Seminar Nr. 84, Lantbruksväxternas Övervintring. Jokioinen, Finland. p. 59 . 66.

— \& LARSEN, A. 1993. Ice encasement as a component of winter kill in herbage plants. In: Li, P.H. \& Christersson, L. (eds.). Advances in Plant Cold Hardiness. CRC Press, Boca Raton, Ann Arbor, London, Tokyo. p. 229-249.

GulloRD, M. 1974. Genetics of freezing hardiness in winter wheat (Triticum aestivum L.). Dissertation for the degree of doctor of philosophy, Michigan State Univ. 70 p.

GustA, L. V. 1986. The induction and maintenance of cold hardiness in winter cereals. NJF Seminar Nr. 84, Lantbruksväxtemas Övervintring. Jokioinen, Finland. p. 9 28.

Hänninen, P. \& Jamalainen, E. A. 1968. Syysviljojen talvehtiminen Keski-Suomessa. Summary: Overwintering of winter cereals in Central Finland. Ann. Agric. Fenn. 7 194-218.

Hensleigh, P. F., Blake, T. K. \& Welty, L. E. 1992. Natural selection on winter barley composite cross XXVI affects winter survival and associated traits. Crop Sci. 32: 57-62.

Hetherington, P. R., McKersie, B. D. \& Keeler, L. C. 1990. The influence of mineral nutrition on the expression of traits associated with winterhardiness of two winter wheat (Triticum aestivum L.) cultivars. Can. J. Plant Sci. 70: 443-454.

Но̆мм0̈, L. M. 1992. Hardening ability of some winter wheat, winter rye and winter barley varieties. Use of conductivity method in evaluating the hardening ability of overwintering crop species. Norwegian J. Agric. Sci. 7 (Suppl.): 39-50.

JAMALAINEN, E. A. 1974. Resistance in winter cereals and grasses to low-temperature parasitic fungi. Ann. Rev. Phytopathol. 12: 281-302.

JENKINS, B. C. 1963. Secale additions and substitutions to common wheat. Proc. 2nd Int. Wheat Symp., Lund. Sweden. p. 301-310.

Kolar, S. C., Hayes, P. M., Chen, T. H. H. \& Linderman, R. G. 1991. Genotypic variation for cold tolerance in winter and facultative barley. Crop Sci. 31: 1149-1152.

Lazar, M. D., Chen, T. H. H., Gusta, L. V. \& Kartha, K. K. 1988. Somaclonal variation for freezing tolerance in a population derived from Norstar winter wheat. Theor. Appl. Genet. 75: 480-484.

LeVIrT, J. 1972. Responses of plants to environmental stresses. Physiological Ecology. Academic Press, New York. 697 p.

Limin, A. E., DvoraK, J. \& Fowler, D. B. 1985. Cold hardiness in hexaploid triticale. Can. J. Plant Sci. 65: 487-490.

— \& Fowler, D. B. 1984. The effect of cytoplasm on cold hardiness in alloplasmic rye (Secale cereale L.) and triticale. Can. J. Genet. Sytol. 26: 405-408.

— \& Fowler, D. B. 1986. Use of related species for the improvement of cold tolerance in wheat. Can. J. Plant Sci. 67: 282 .

— \& Fowler, D. B. 1988. Cold hardiness expression in interspecific hybrids and amphiploids of the Triticae. Genome 30: 361-365.

— \& FowlER, D. B. 1991. Breeding for cold hardiness in winter wheat: problems, progress and alien gene expression. Field Crops Res. 27: 201-218.

McKersie, B. D. \& Hunt, L. A. 1987. Genotypic differences in tolerance of ice encasement, low temperature flooding, and freezing in winter wheat. Crop Sci. 27: 860-863.

Metcalf, E. L., Cress, C. E., Olein, C. R. \& Everson, E. H. 1970. Relationship between crown moisture content and killing temperature for three wheat and three barley cultivars. Crop Sci 10: 362-365.

NissıNEN, O. 1986. Näringsämnens inverkan på utvintringssvamparnas angrepsgrad. NJF Seminar Nr. 84, Lantbruksväxternas Övervintring. Jokioinen, Finland. p. 101-107.

Olvång, H. 1992. Chemical control of winter damaging fungi in cereals. Norwegian J. Agric. Sci. 7(Suppl.): 5563.

Pohjakallio, 0., Salonen, A., Antilla, S. \& Halkilahti A.-M. 1962. Syysviljan talvehtimiseen vaikuttavista tekijöistä. Summary: Studies on factors affecting the over- 
wintering of winter cereals. Maatalous ja Koetoiminta 16: $140-152$.

Pomeroy, M. K. \& Andrews, C. J. 1989. Low temperature injury in winter cereals. In: Li, P.H. (ed.). Low Temperature Stress Physiology in Crops. CRC Press, Boca Raton, FL. p. 107-122.

-, Andrews, C. J. \& FedaK, G. 1975. Cold hardening and dehardening responses in winter wheat and winter barley. Can. J. Plant Sci. 55: 529-535.

Pullı, S. 1986. Climatic factors in relation to winterhardiness. NJF Seminar Nr. 84, Lantbruksväxternas Övervintring. Jokioinen, Finland. p. 48-59.

RoBERTS, D. W. A. 1990. Identification of loci on chromosome 5A of wheat involved in control of cold hardiness, vernalization, leaf length, rosette growth habit, and height of hardened plants. Genome 33: 247-259.

Rohde, C. R. \& Pulham, C. F. 1960. Heritability estimates of winter hardiness in winter barley determined by the standard unit method of regression analysis. Agron. J. 52: 584-586,

SMrrH, J. D. 1986. Snow mould diseases of crop plants in westem Canada. NJF Seminar Nr. 84, Lantbruksväxternas Övervintring. Jokioinen, Finland. p. 119-129.
- 1987. Winter-hardiness and overwintering diseases of amenity turfgrasses with special reference to the Canadian Prairies. Agric. Can. Res. Branch Techn. Bull. 198712E. 192 p.

STEPONKUS, P. L. 1978. Cold hardiness and freezing injury of agronomic crops. Adv. Agr. 30: 51-98.

SutKA, J. 1981. Genetic studies of frost resistance in wheat. Theor. Appl. Genet. 59: 145-152.

URVAS, L. 1986. The effect of fertilization on the overwintering of timothy. NJF Seminar Nr. 84, Lantbruksväxternas Övervintring. Jokioinen, Finland. p. 29-34.

VeIsZ, O. \& RAJKI, E. 1987. Frost resistance in various winter wheat varieties during winter. Acta Agronomica Hungarica 36: 285-294.

Manuscript received July 1993

Leena Hömmö

Seppo Pulli

Agricultural Research Centre of Finland

Institute of Plant Breeding

FIN-31600 Jokioinen, Finland

\title{
SELOSTUS
}

\section{Syysvehnä-(Triticum aestivum), syysruis-(Secale cereale), ruisvehnä-(x Triticosecale) ja syysohra (Hordeum vulgare) lajikkeiden talvenkestävyys kuudella koepaikalla Suomessa}

\author{
LEENA HÖMMÖ ja SEPPO PULLI
}

Maatalouden tutkimuskeskus

Tutkimuksessa selvitettiin kolmen vuoden (1989-1992) aikana 24 syysvehnä-, 13 ruis-, 5 ruisvehnä- (triticale) ja 11 syysohralajikkeen talvenkestävyyttä kuudella eri koepaikalla (Mietoinen, Jokioinen, Pälkäne, Anjalankoski, Laukaa ja Sotkamo). Lajikkeet oli valittu eri puolilta syysviljojen viljelyvyöhykettä, ja niiden talvenkestävyydessä tiedettiin olevan suurta vaihtelua hyvin kestävistä huonosti talvehtiviin, lähes kevätmuotoja muistuttaviin lajikkeisiin.

Kokeen tulosten perusteella ruis on syysviljoista selvästi talvenkestävin. Syysvehnä ja ruisvehnä ovat talvenkestävyydeltään hyvin lähellä toisiaan ja huomattavasti syysohraa kestävämpiä. Lajikkeiden talvenkestävyys oli tilastollisesti erittäin merkitsevästi erilainen kaikissa niissä kokeissa, joiden aikana oli ollut kylmä ja runsasluminen talvi. Talvet olivat koejakson aikana hyvin vaihtelevia, ja eri koepaikoilla kasvit joutuivat selviytymään hyvin erilaisista stressitekijöistä. Kasvien yleisen talvenkestävyyden katsotaan olevan additiivisen, osittain dominanssiin perustuvan geenitoiminnan săätelemäă, jolloin erilaisissa stressiolosuhteissa lajikkeiden kestävyysjärjestys on aina hieman erilainen.
Kokeiden perusteella syysohran talvenkestävyyden testaamiseen soveltuu koepaikoista parhaiten Mietoinen ja Jokioinen, kun taas syysvehnän, rukiin ja ruisvehnän lajike-erot tulivat parhaiten esille Laukaassa ja Sotkamossa. Kestävimmät syysvehnälajikkeet Suomen oloissa olivat: Linna, Vakka, Kosack, Albidom 12 ja Aura. Ruislajikkeista parhaiten talvehtivat: Jussi, Voima, Anna ja Norderås tetra ja ruisvehnistä linjat Sv 856003 ja Sj 868013.

Syysohraa ei Suomessa viljellä kaupallisesti, mutta kestävimpien lajikkeiden: Borwina, Andrea ja Frost talvenkestävyys näyttäisi riittävän viljelyyn eteläisessä ja Lounais-Suomessa.

Syysvehnän ja ruisvehnän talvehtimiselle näyttää kokeen tulosten perusteella olevan edullista matala kasvutapa, kun taas ruis talvehtii paremmin, jos se on kasvutavaltaan pysty.

Kokeiden tulokset korreloivat yleensä erittäin hyvin yhteispohjoismaisten, vastaavien kenttäkokeiden kanssa. Erityisen hyvä korrelaatio oli niiden kokeiden kanssa, joissa runsas lumi oli katsottu tärkeimmäksi stressitekijäksi. 


\title{
Hardening ability of some winter wheat, winter rye and winter barley varieties
}

\author{
Use of conductivity method in evaluating the hardening ability \\ of overwintering crop species
}

\author{
HÖMMÖ, LEENA MAARIT
}

Agricultural Research Centre, Institute of Plant Breeding, Jokioinen, Finland

\begin{abstract}
Hömmö, L.M. 1992. Hardening ability of some winter wheat, winter rye and winter barley varieties. Use of conductivity method in evaluating the hardening ability of overwintering crop species. Norwegian Journal of Agricultural Sciences, Supplement No. 7. 39-50. ISSN 080)1-5341.
\end{abstract}

\begin{abstract}
A study of the hardening ability of 12 winter wheat, 8 winter rye and 5 winter barley varieties was carried out using the electric conductivity method. Leaf samples were collected from the field trial during the hardening period and after frost treatment the conductivity of an effusate was determined. The amounts of calcium and potassium ions in the leachate were also determined. The injury index and indexes for calcium and potassium were calculated. During the hardening period there was a distinct decrease in the conductivity values indicating the increase in the level of hardening. The same decrease was also found in the amounts of both calcium and potassium ions in the effusate. In most cases a clear negative correlation was found between the index values and overwintering capacity of varieties. The results of this study indicate that the conductivity method can be used in estimating the level of winter hardiness of winter wheat, winter rye and winter barley varieties.
\end{abstract}

Key words: Cold hardiness, conductivity, frost tolerance, ion leakage, rye, winter barley, winter wheat.

Leena Maarit Hömmö, Agricultural Research Centre, Institute of Plant breeding, $S F-31600$ Jokioinen, Finland.

Since both winter wheat and winter rye reach their northernmost growth limit in Finland, winter barley in Sweden, one of the most important tasks in the breeding work of these species is to enhance their winter hardiness. This, however, is a rather complex undertaking because of the many different kinds of stresses and changes in weather conditions during the winter period. Consequently, there is a great need for laboratory testing methods that enable the breeder to obtain sufficiently reliable estimates on the winter hardiness of varieties and breeder lines of overwintering crops. Laboratory methods are of particular value in the screening of early generations of these crops. To be of any use to practical breeders, these methods should be repeatable, simple, rapid and cheap. To help this situation an internordic project was initiated in 1989 with the aim of developing reliable laboratory testing methods for winter hardiness breeding. 
Winter hardiness of an overwintering crop variety depends on its ability to harden during the autumn period. The hardening process in itself includes a very complicated series of plant reactions to changes in the environment (decreasing temperature, shortening of photoperiod) by altering its metaboly on a cellular level. If the plant is unable to make these changes, or if they are delayed, the first frosts in winter will lead to cell damage.

The use of the electric conductivity method, or ion leakage method as it is also called, is based on the idea that during frost treatment the cell membranes are damaged to some degree and this leads to an efflux of ions through the cell membrane to the effusate. The basic assumption is that the greater the damage to the tissue the more ions that are leaked out.

The electric conductivity method was introduced into frost hardiness research by Dexter et al. (1930, 1932), and it has been quite extensively used by many researchers ever since. Flint et al. (1967) studied the frost resistance of ornamental shrubs, strawberry crowns and the roots of apple trees. They also determined different kinds of injury indexes to obtain better evaluations of the amount of cell injury. According to Wilner (1960) the ion leakage method is a very reliable means of determining "both relative and absolute ratings of hardiness of apple trees as well as a means of studying the effect of certain seasonal changes on their (plant) winter survival". Aronsson \& Eliasson (1970) found good correlation between frost hardiness of hardy Scots pine tissues and cell injury estimations obtained by conductivity measurements. The seasonal changes in hardening and dehardening of the mountain plant Diapensia lapponica were studied with the aid of the conductivity method by Junnila (1985). Sukumaran \& Weiser (1972) were able to differentiate Solanum species representing a wide range of frost tolerance by using conducti- vity measurements.

Frost hardiness of overwintering cereals has been studied by electric conductivity measurements by e.g. Chen et al. (1983) and Uemura \& Yoshida (1984). They found that this method gave reliable estimations of the amounts of damaged or dead cells after frost treatment. Palta et al. (1977a, 1977b) used onion bulb cells in their studies, and they discovered that not only dead, but also reversibly or irreversibly damaged cells, are responsible for the efflux of ions to the effusate.

In this study the state and progress of hardening in field conditions in the autumn time were studied in 12 winter wheat, 8 winter rye and 5 winter barley varieties by the conductivity method. The amount of calcium and potassium ions in the effusate was also determined. On the basis of these measurements injury indexes were calculated and the correlations between the index values and overwintering capacity were studied.

\section{MATERIALS AND METHODS}

The field trial from which the leaf samples for conductivity measurements were collected was sown in Jokioinen $\left(60^{\circ} 49^{\prime} \mathrm{N}, 23^{\circ} 29^{\prime} \mathrm{E}\right)$ on 27 August 1990. The trial comprised 24 winter wheat, 13 winter rye, 5 winter triticale and 12 winter barley varieties. In these conductivity measurements 12 winter wheat varieties (Linna, Aura, Vakka, Albidom 12, Kharkov, Norstar, Mironowskaja 808, Frederick, Goertzen 5559, Rida, Longbow and Vitus), 8 winter rye varieties (Musketeer, Anna, Voima, Talovskaja 
12, Vågonäs höstråg, Jussi, Petkus II and Danko) and 5 winter barley varieties (Borwina, Frost, Lady, Igri and Maris Otter) were included.

The trial entries were sown in one-metre-long rows, and the trial was completely randomized with four replicates.

The leaf samples were collected from the field trial once a week, beginning on 9 October. The last samples were collected on 20 November just before the permanent snow cover.

The first leaves of the plants were cut in the field and put into the plastic bags. The leaves were rinsed quickly with cold tap water, and control samples (10 leaves per variety) were put on ice to keep them cool while being prepared for the conductivity measurements.

The rest of the samples (about 20 leaves per variety) were transferred in the plastic bags into the freezing chamber and the freezing programme was started immediately. At the beginning of the programme the temperature was at about $0^{\circ} \mathrm{C}$. The whole programme took 24 hours. During the first eight hours the temperature dropped to $-12^{\circ} \mathrm{C}$ in $1.5^{\circ}$ /hour. The temperature was maintained at $-12^{\circ} \mathrm{C}$ and then reset to $0^{\circ} \mathrm{C}$ after eight hours.

After frost treatment, while preparing the samples for conductivity measurements, the plastic bags with the leaves were covered with ice in a styrox box to minimize any cell injury that might be caused by the rapid changes in temperature.

The samples in all the conductivity measurements comprised five leaf pieces originating from five different plants. The leaf pieces were weighed together to provide a sample of about $100 \mathrm{mg}$. After this the samples were shaken for about $5 \mathrm{~h}$ at room temperature in test tubes containing $20 \mathrm{ml}$ of deionized water. Before immersion in water the five leaf pieces were put in a single-use needle (Terumo nr. 14) to ensure that all the pieces were totally under water.

The shaking period was followed by determination of the conductivity of the effusate. These measurements were carried out using the Radiometer Copenhagen CDM 83 conductivity meter. After the first measurements were taken half of the frostdamaged samples were totally killed by submerging them for five minutes in liquid nitrogen. All samples were shaken in the effusate for one more hour and the final conductivity measurements were carried out.

Finally, all the effusates were frozen in single-use plastic test tubes for later determination of calcium and potassium content.

The effusate was analysed for calcium and potassium content by atomic absorption spectrophotometer $\left(\mathrm{Ca}^{2+}\right.$ by Perkin-Elmer 4000 and $\mathrm{K}^{+}$by Varian techtron 1200).

Based on the obtained conductivity values and values for leaked $\mathrm{Ca}^{2+}$ and $\mathrm{K}^{+}$ions, the index of injury and indexes for calcium and potassium were calculated according to the formulae: 
INDEX OF INJURY

$$
\frac{(B-A) \times 100}{(C-A)}
$$

where $\quad A=$ conductivity of effusate of unfrozen sample

$\mathrm{B}=$ conductivity of effusate of frost-injured sample

$\mathrm{C}=$ conductivity of effusate of frost-injured and then liquid-nitrogen-killed sample

INDEX OF CALCIUM AND POTASSIUM CONTENT IN EFFUSATE

$$
\begin{aligned}
& \frac{\left(\mathrm{Ca}^{2+} \mathrm{B}-\mathrm{Ca}^{2+} \mathrm{A}\right) \times 100}{\mathrm{Ca}^{2}+\mathrm{C}-\mathrm{Ca}^{2+} \mathrm{A}} \\
& \frac{(\mathrm{K}+\mathrm{B}-\mathrm{K}+\mathrm{A}) \times 100}{\mathrm{~K}+\mathrm{C}-\mathrm{K}+\mathrm{A}}
\end{aligned}
$$

where $\mathrm{Ca}^{2}+\mathrm{A}, \mathrm{K}+\mathrm{A}=$ calcium and potassium content in effusate of unfrozen sample

$\mathrm{Ca}^{2}+\mathrm{B}, \mathrm{K}+\mathrm{B}=$ calcium and potassium content in effusate of frost-injured sample

$\mathrm{Ca}^{2}+\mathrm{C}, \mathrm{K}+\mathrm{C}=$ calcium and potassium content in effusate of frost-injured and then liquid-nitrogen-killed sample

The overwintering capacity values of varieties used in correlation analyses were based on the means of winter survival percentages of varieties in field trials sown in 17 sites throughout the Nordic countries. These field trials are a part of an internordic winterhardiness project initiated by Internordic Plant Breeding (SNP) in 1989. The trials were sown in autumn 1989 according to the plan described above.

Pearson's correlation analysis (SAS Institute Inc. 1985) was used in studying the relations between overwintering capacity of varieties and various indexes

\section{RESULTS}

During the hardening period (9 October-15 November 1990) the state and progress of hardening of winter wheat, winter rye and winter barley varieties were studied using the electric conductivity method. In all species the conductivity of an effusate decreased during the hardening period (Table 1). In winter wheat the values were low at the beginning of the period so the change was not so clear-cut, but in winter rye and in winter barley a very pronounced decrease in ion leakage was observed.

The average winter survival percentages of varieties in winter 1989-90 were calculated by Hjortsholm (1991) on the basis of results from field trials of the Internordic Plant Breeding project (Table 2). These survival percentages were used in this study as overwintering capacity values of varieties. 
Table 1. The conductivities of effusates in which frost injured leaf samples of winter wheat, winter rye and winter barley have been soaked. Samples were collected from field trials during the hardening period in 1990 . The conductivity values are $\mu \mathrm{S} / \mathrm{cm}$

\begin{tabular}{|c|c|c|c|c|c|c|}
\hline & \multicolumn{3}{|c|}{ October } & \multicolumn{3}{|c|}{ November } \\
\hline & $9-17$ & $22-25$ & $29.10-1.11$ & $5-8$ & $12-15$ & $19-20$ \\
\hline \multicolumn{7}{|l|}{ Winter wheat: } \\
\hline Linna & 13.0 & 8.6 & 12.5 & 7.5 & 13.2 & 6.6 \\
\hline Aura & 13.0 & 8.4 & 10.2 & 12.1 & 10.1 & 7.7 \\
\hline Vakka & 9.3 & 8.1 & 12.3 & 17.6 & 10.0 & 5.8 \\
\hline Albidom 12 & 10.3 & 6.3 & 9.3 & 11.7 & 9.8 & 6.7 \\
\hline Kharkov & 7.2 & 11.4 & 9.4 & 12.4 & 10.6 & 6.8 \\
\hline Norstar & 6.6 & 6.7 & 8.8 & 6.5 & 8.7 & 5.9 \\
\hline Mironowskaja 808 & 30.0 & 9.4 & 9.7 & 9.8 & 9.1 & 5.7 \\
\hline Frederick & 17.5 & 10.5 & 16.3 & 9.3 & 12.8 & 5.5 \\
\hline Goertzen 5559 & 11.7 & 7.1 & 7.1 & 11.2 & 9.2 & 8.2 \\
\hline Rida & 16.0 & 14.3 & 26.2 & 18.1 & 10.3 & 4.7 \\
\hline Longbow & 51.0 & 13.5 & 14.1 & 35.9 & 14.5 & 5.7 \\
\hline Vitus & & & & 90.9 & 33.7 & 8.7 \\
\hline \multicolumn{7}{|l|}{ Winter rye: } \\
\hline Musketeer & 14.3 & 19.1 & 12.7 & 4.8 & 6.0 & \\
\hline Anna & 40.5 & 14.1 & 11.1 & 5.3 & 7.6 & \\
\hline Voima & 42.0 & 19.3 & 13.1 & 6.5 & 7.5 & \\
\hline Talovskaja 12 & 39.6 & 6.5 & 9.1 & b. 1 & 5.6 & \\
\hline Vågonäs höstråg & 32.4 & 10.4 & 10.1 & 7.5 & 5.9 & \\
\hline Jussi & 39.5 & 12.4 & 18.1 & 9.0 & 6.5 & \\
\hline Petkus II & 79.2 & 24.8 & 28.5 & 5.6 & 7.3 & \\
\hline Danko & 63.9 & 35.4 & 11.5 & 10.5 & 0.4 & \\
\hline \multicolumn{7}{|l|}{ Winter barley: } \\
\hline Borwina & 86.0 & 78.1 & 37.4 & 30.1 & 25.4 & \\
\hline Frost & 95.6 & 71.3 & 68.5 & 14.3 & 21.3 & \\
\hline Lady & 97.6 & 74.0 & 72.5 & 47.8 & 21.9 & \\
\hline Igri & 81.4 & $5 \times .9$ & 72.9 & 22.3 & 31.2 & \\
\hline Maris Otter & $\varphi 7.3$ & 76.7 & 81.6 & 11.1 & 18.9 & \\
\hline
\end{tabular}

Table 2. Winter survival percentages of winter wheat, winter rye and winter barley varieties. Values are based on results from field trials in all the Nordic countries. The mean values are calculated by Hjortsholm (1991)

\begin{tabular}{lcllll}
\hline & $\begin{array}{c}\text { Survival } \\
\%\end{array}$ & Winter rye & $\begin{array}{c}\text { Survival } \\
\%\end{array}$ & Winter barley & $\begin{array}{c}\text { Survival } \\
\%\end{array}$ \\
\hline Linter wheat & 86.3 & Anna & 83.5 & Borwina & 52.0 \\
Aura & 82.1 & Voima & 80.0 & Frost & 38.8 \\
Vakka & 81.2 & Talovskaja & 79.9 & Lady & 31.7 \\
Albidom 12 & 78.9 & Văgonäs & 79.0 & Igri & 28.3 \\
Norstar & 75.8 & höstrog & & Maris Otter & 13.7 \\
Frederick & 72.5 & Jussi & 77.9 & & \\
Goertzen 5559 & 67.4 & Petkus II & 69.4 & & \\
Rida & 67.3 & Danko & 67.3 & & \\
Longbow & 46.4 & & & & \\
Vitus & 2.3 & & & & \\
\hline
\end{tabular}


When studying the correlations between overwintering capacity and index of injury of varieties, a definite negative correlation was found in most cases. There was even statistical significance in some results, although the number of varieties studied was quite low (Table 3).

Table 3. Correlations between overwintering capacity of varieties and index of injury. Index values are calculated on the basis of conductivity values of the effusates in which leaf samples have been soaked

\begin{tabular}{llll}
\hline & \multicolumn{3}{c}{ OVERWINTERING } \\
& Winter wheat & Winter rye & Winter barley \\
\hline $\begin{array}{l}\text { INDEX 1 } \\
(9-17.10)\end{array}$ & $-0.86^{* *} \mathrm{~N}=10$ & $-0.76^{*} \mathrm{~N}=7$ & $-0.70 \mathrm{~N}=5$ \\
$\begin{array}{l}\text { INDEX } 2 \\
(22-25.10)\end{array}$ & -0.32 & $-0.88 \cdots$ & -0.37 \\
$\begin{array}{l}\text { INDEX 3 } \\
(29.10-1.11)\end{array}$ & 0.23 & -0.49 & -0.76 \\
$\begin{array}{l}\text { INDEX 4 } \\
(5-8.11)\end{array}$ & $-0.96 \cdots *$ & -0.66 & -0.12 \\
INDEX 5 & & 0.47 & -0.60 \\
$(12-15.11)$ & $-0.77 \cdots$ & 0.0 & \\
\hline
\end{tabular}

At the beginning of the hardening period the amounts of leaked calcium and potassium ions in the effusate varied in winter wheat between $0.00-0.88 \mathrm{mg} / \mathrm{l}$ and $1.13-14.91 \mathrm{mg} / \mathrm{l}$ for calcium and potassium respectively. The same values were $0.10-3.70 \mathrm{mg} / \mathrm{l}$ (calcium) and 3.37-18.96 mg/l (potassium) for winter rye and 1.45-3.65 mg/l (calcium) and 23.1$27.7 \mathrm{mg} / \mathrm{l}$ (potassium) for winter barley.

At the end of the test period the values for winter wheat were $0.15-0.81 \mathrm{mg} / \mathrm{l}$ (calcium) and 1.32-2.34 mg/l (potassium), for winter rye $0.08-0.38 \mathrm{mg} / \mathrm{l}$ (calcium) and 0.63 $1.24 \mathrm{mg} / \mathrm{l}$ (potassium) and for winter barley $0.64-2.78 \mathrm{mg} / \mathrm{l}$ (calcium) and 1.63-7.05 mg/l (potassium).

The amounts of calcium and potassium ions in the effusate decreased very markedly during the hardening period in winter rye and winter barley varieties. In most winter wheat varieties the amounts of both ions in the effusate were already low when the measurements were first carried out and consequently no clear-cut changes were observed (Figs. 1-6).

In all species there was a distinctly negative correlation between the overwintering capacity of varieties and calcium and potassium indexes (Tables 4, 5, and 6). The correlation between the potassium index and overwintering capacity in particular was usually very clear.

\section{DISCUSSION}

The ability of plants to react to the lowering of the temperature and shortening of the photoperiod by changing their cell metaboly is the prerequisite to good winter hardiness. In particular changes in chemical properties of cell membranes during acclimation are supposed to be of great importance (Kasamo 1988; Palta 1977a, b; Palta \& Li 1982; Steponkus 1984; Uemura \& Steponkus 1989; Uemura \& Yoshida 1984). It is generally agreed that the plasma membrane is the primary site of freezing injury, but 


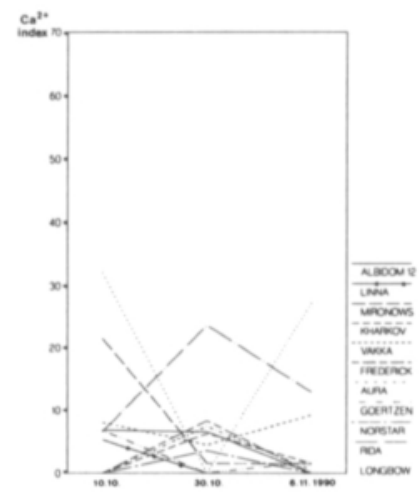

Fig. 1. The changes in the calcium index values of winter wheat varieties during the hardening period in autumn 1990

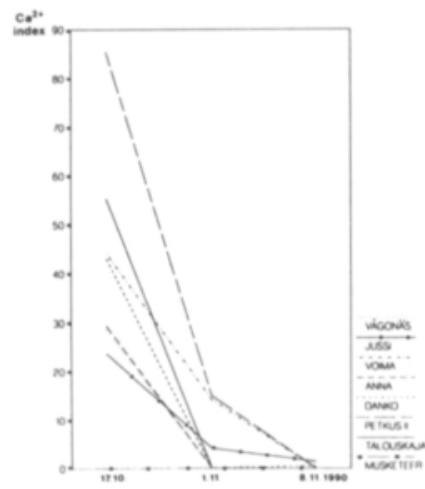

Fig. 3. The changes in the calcium index values of winter rye varieties during the hardening period in autumn 1990)

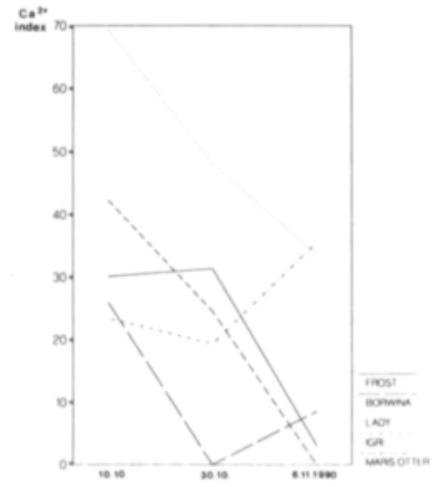

Fig. 5. The changes in the calcium index values of winter barley varieties during the hardening period in autumn 1990

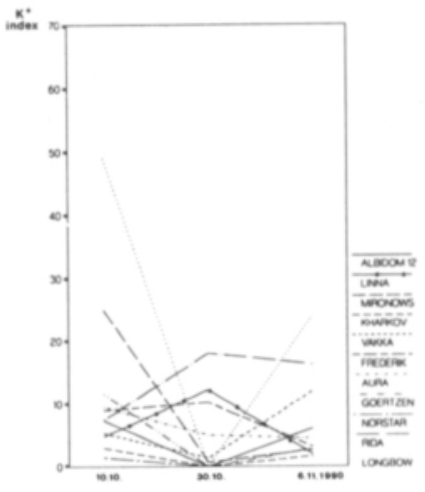

Fig. 2. The changes in the potassium index values of winter wheat varieties during the hardening period in autumn 1990

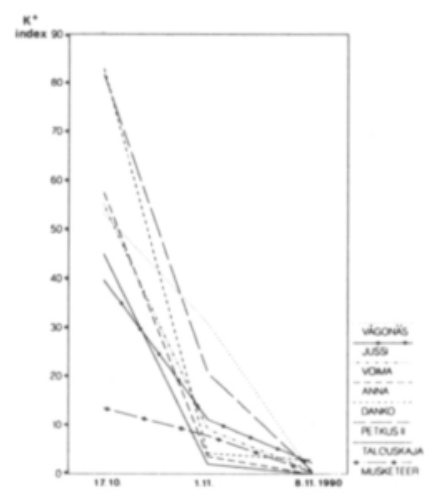

Fig. 4. The changes in the potassium index values of winter rye varieties during the hardening period in autumn 1990

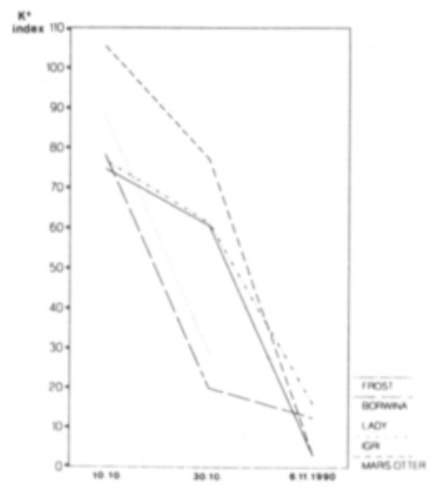

Fig. b. The changes in the potassium index values of winter barley varieties during the hardening period in autumn 1990 
Table 4. Correlation between overwintering capacity of winter wheat varieties and their state of hardening determined by $\mathrm{Ca}^{2+}$ - and $\mathrm{K}^{+}$contents in the effusate

Table 5. Correlation between overwintering capacity of winter rye varieties and their state of hardening determined by $\mathrm{Ca}^{2+}-$ and $\mathrm{K}^{+}$content in the effusate

Date of collecting samples from field
Correlation coefficients Overwintering

\begin{tabular}{llll}
\hline 10.10 .90 & $\mathrm{Ca}^{2+}$ & $-0.800^{* *}$ & $\mathrm{~N}=9$ \\
30.10 .90 & $\mathrm{~K}^{+}$ & $-0.87^{* *}$ & $\mathrm{~N}=9$ \\
& $\mathrm{Ca}^{2+}$ & 0.01 & $\mathrm{~N}=9$ \\
6.11 .90 & $\mathrm{~K}^{+}$ & 0.16 & $\mathrm{~N}=9$ \\
& $\mathrm{Ca}^{2+}$ & $-0.97 * * *$ & $\mathrm{~N}=9$ \\
& $\mathrm{~K}^{+}$ & $-0.95^{* * *}$ & $\mathrm{~N}=9$ \\
\hline
\end{tabular}

Table 6. Correlation between overwintering capacity of winter barley varieties and their state of hardening determined by $\mathrm{Ca}^{2+}$ and $\mathrm{K}^{+}$-content in the effusate

\begin{tabular}{llll}
\hline $\begin{array}{l}\text { Date of collecting } \\
\text { samples from field }\end{array}$ & $\begin{array}{c}\text { Correlation coefficients } \\
\text { Overwintering }\end{array}$ \\
\hline 17.10 .90 & $\mathrm{Ca}^{2+}$ & -0.54 & $\mathrm{~N}=7$ \\
1.11 .90 & $\mathrm{~K}^{+}$ & $-0.82^{*}$ & $\mathrm{~N}=7$ \\
& $\mathrm{Ca}^{2+}$ & 0.23 & $\mathrm{~N}=7$ \\
& $\mathrm{~K}^{+}$ & 0.12 & $\mathrm{~N}=7$ \\
& $\mathrm{Ca}^{2+}$ & -0.01 & $\mathrm{~N}=7$ \\
& $\mathrm{~K}^{+}$ & -0.62 & $\mathrm{~N}=7$ \\
\hline
\end{tabular}

Date of collecting samples from field

Correlation coefficients Overwintering

\begin{tabular}{llrl}
\hline 10.10 .90 & & & \\
& $\mathrm{Ca}^{2+}$ & -0.31 & $\mathrm{~N}=5$ \\
30.10 .90 & $\mathrm{~K}^{+}$ & -0.77 & $\mathrm{~N}=5$ \\
& $\mathrm{Ca}^{2+}$ & 0.44 & $\mathrm{~N}=5$ \\
6.11 .90 & $\mathrm{~K}^{+}$ & 0.78 & $\mathrm{~N}=5$ \\
& $\mathrm{Ca}^{2+}$ & -0.02 & $\mathrm{~N}=5$ \\
& $\mathrm{~K}^{+}$ & -0.16 & $\mathrm{~N}=5$ \\
\hline
\end{tabular}

how this comes about is still not clear. As a result of freezing injury, ions and also sugars are leaked out from damaged cells. The electric conductivity method is based on an assumption that the more the cells of a plant are damaged during the frost treatment, the higher the conductivity of an effusate and the poorer the frost hardiness of a given variety.

In this study the hardening ability of some winter wheat, winter rye and winter barley varieties was studied using the electric conductivity method. According to this method most of the winter wheat varieties were already quite well hardened by the be- 
ginning of the test period, and only a slight decrease in conductivity values during the hardening period was observed.

The conductivity values of winter rye and winter barley cultivars were high at the beginning of the test period, but they decreased, especially in rye, very rapidly. The last conductivity values were determined just before the permanent snow cover. On the whole, winter rye varieties had the lowest conductivity values, and thus it is expected that their hardening ability and also winter hardiness will be very good. The conductivity values of winter wheat varieties were also quite low, indicating rather good winter hardiness. In winter barley the conductivity values were still very high in the late autumn, which means that winter barley varieties were inadequately hardened before the snow cover, and the plants will in all probability be damaged to some degree during the winter time.

The injury index was determined in order to take into consideration the amount of ions leaked out of cells of unfrozen samples and also the total ion leakage from samples killed by liquid nitrogen. Usually a very clear negative correlation was found between the overwintering capacity of varieties and the values of the injury index.

The amounts of calcium and potassium ions in the effusate were also determined and the calcium and potassium indexes were calculated in the same way as the injury index. These indexes were used to investigate how well the amount of leaked ions in the effu- sate correlates with the overwintering capacity of varieties, and whether these two ions differ from each other in this respect.

In this study the concentration of potassium in the effusate was about 10 times that of calcium. According to Palta et al. (1977a) the major cation present in the effusate is potassium. They found that when potassium and the same amount of correspondent anion (probably $\mathrm{Cl}^{-}$) are combined they account for practically all of the conductivity of an effusate. In their onion bulb scale studies they found the amount of leaked potassium ions to be almost 100 times that of calcium.

A pronounced negative correlation was found in most cases between calcium and potassium indexes and overwintering capacity of varieties. The potassium index values seem to give more reliable estimates of the state of hardening of varieties than the calcium indexes. This is also to be expected since the amounts of calcium in the effusate are very small.

There are considerable fluctuation especially in the values of winter wheat varieties during the hardening period. The reason for this could be that winter wheat varieties were already quite well hardened by the beginning of the test period, and the amount of ions leaked out of the cells possibly always varies within some limits. According to Pomeroy et al. (1975) the probability of dehardening during the quick preparation of samples at room temperature is very small, at least as far as winter wheat or winter barley varieties are concerned. Thus the samples entered in the freezing test should have the same level of hardening they had obtained in the field. On the other hand Pomeroy et al. (1975) discovered that winter wheat varieties in particular dehardened quite easily during a prolonged period of slightly higher temperatures.

In Finland the weather in autumn 1990 was quite cold at the end of September and at the beginning of October, so the conditions were very favourable for the hardening of plants. There was a warm period in the middle of October (9-18 October) during which the daily temperatures were above $+10^{\circ} \mathrm{C}$, and night temperatures were also 
between $0^{\circ} \mathrm{C}$ and $+10^{\circ} \mathrm{C}$. After this warm period, the temperature began to drop again, the night temperatures in particular going down quite suddenly.

Most of the variation in the conductivity and also in the calcium and potassium values could be explained according to the weather conditions during the hardening period. The long warm period in October could have induced the dehardening process especially in sensitive winter wheat varieties. In dehardened plants the freezing test resulted in an increased incidence of cell injury.

The overwintering capacity values used in this study are based on survival percentages in field trials from the year 1989-90. That particular winter was very mild throughout the Nordic countries, and this could have obscured the results of the correlation analysis to some extent. The survival percentages of winter rye varieties in particular were very high. In these conditions it is difficult to differentiate between varieties with almost the same level of winter hardiness, and this could have caused inaccuracy in the ranking list of varieties.

\section{SUMMARY}

According to the results of this study the electric conductivity method seems to give quite reliable estimations of the level of winter hardiness of winter wheat, winter rye and winter barley varieties. Potassium seems to be the main cation leaked out of the damaged cells. A clear negative correlation was found between the amount of $\mathrm{K}^{+}$-ions in the effusate and the overwintering capacity of varieties.

Since the electric conductivity method is quite simple, reproducible and reliable, it could possibly also be used in practical breeding work when breeding material is screened on the basis of winter hardiness.

\section{ACKNOWLEDGEMENTS}

The author thanks Professor Seppo Pulli for his enthusiasm in starting the internordic winterhardiness project, which has made these studies possible, and Marja-Leena Manninen for technical assistance.

\section{REFERENCES}

Aronsson, A. \& L. Eliasson 1970. Frost hardiness in Scots pine (Pinus silvestris L.). I. Conditions for tests on hardy plant tissues and for evaluation of injuries by conductivity measurements. Studia Forestalia Suecica 77: 1-30.

Chen, T.H., L.V. Gusta \& D.B. Fowler 1983. Freezing injury and root development in winter cereals. Plant Physiol. 73: 773-777.

Dexter, S.T., W.E. Tottingham \& L.F. Graber 1930. Preliminary results in measuring the hardiness of plants. Plant Physiol. 5: 215-223. 
Dexter, S.D., W.E. Tottingham \& L.F. Graber 1932. Investigations of the hardiness of plants by measurement of electrical conductivity. Plant Physiol. 7: 63-78.

Flint, H.L., B.R. Boyce \& D.J. Beattie 1967. Index of injury - a useful expression of freezing injury to plant tissue as determined by the electrolytic method. Can. J. Plant Sci. 47: 229-230.

Hjortsholm, K. 1991. Development and comparison of different laboratory methods testing winterhardiness in cereals. NJF-seminar no. 188 Ås, Norway, February 11-14, 1991.

Junnila, S. 1985. Seasonal changes in cold hardiness of Diapensia lapponica. Aquilo Ser. Bot. 23: 81-85.

Kasamo, K. 1988. Response of tonoplast and plasma membrane ATP:- ases in chillingsensitive and -insensitive rice (Oryza sativa L.) culture cells to low temperature. Plant Cell Physiol. 29 (7): 1085-1094.

Palta, J.P., J. Lewitt \& E.J. Stadelmann 1977a. Freezing injury in onion bulb cells. I. Evaluation of the conductivity method and analysis of ion and sugar efflux from injured cells. Plant Physiol. 60: 393-397.

Palta, J.P., J. Lewitt \& E.J. Stadelmann 1977b. Freezing injury in onion bulb cells. II. Post-thawing injury or recovery. Plant Physiol. 60: 398-401.

Palta, J.P. \& P.H. Li 1982. Cell membrane properties in relation to freezing injury. In: P.H. Li \& A. Sakai, (eds.) Plant Cold Hardiness and Freezing Stress: Mechanisms and Crop Implications, Vol 2. Academic Press, New York. Pp. 93-115.

Pomeroy, M.K., C.J. Andrews, \& G. Fedak 1975. Cold hardening and dehardening responses in winter wheat and winter barley. Can. J. Plant Sci. 55: 529-535.

SAS Institute Inc., SAS User's Guide: Statistics, Version 5 Ed. Cary, NC:SAS Institute Inc., 1985.

Steponkus, P.L. 1984. The role of plasma membrane in freezing injury and cold acclimation. Annu. Rev. Plant Physiol. 35: 563-584.

Sukumaran, N.P. \& C.J. Weiser 1972. An excised leaflet test for evaluating potato frost tolerance. Hort. Sci. 7(5): 467-468.

Uemura, M. \& P.L. Steponkus 1989. Parallel effects of freezing and osmotic stress on the ATPase activity and protein composition of the plasma membrane of winter rye seedlings. Plant Physiol. 91: 961-969. 
Uemura, M. \& S. Yoshida 1984. Involvement of plasma membrane alterations in cold acclimation of winter rye seedlings (Secale cereale L. cv Puma). Plant Physiol. 75: 818826.

Wilner, J. 1960. Relative and absolute electrolytic conductance test for frost hardiness of apple varieties. Can. J. Plant Sci. 40: 630-637. 
HARDENING OF SOME WINTER WHEAT (Triticum aestivum L.),

RYE (Secale cereale L.), TRITICALE (X Triticosecale Wittmack) AND WINTER BARLEY (Hordeum vulgare L.) CULTIVARS DURING AUTUMN AND THE FINAL WINTER SURVIVAL IN FINLAND

HÖMMÖ, LEENA MAARIT

Agricultural Research Centre of Finland, Institute of Plant Breeding SF-31600 Jokioinen, FINLAND

Plant Breeding (in press) 


\section{ABSTRACT:}

Since profound hardening is the prerequisite for the survival of a cultivar over the winter, in the present study the hardening abilities of 13 winter wheat, 10 rye, 3 triticale and 6 winter barley cultivars were determined in field samples collected during the autumns of 1990 and 1991. The amount of ion leakage from frost treated leaf segments was used to estimate the level of hardening.

Since, field trials have a tendency for very high experimental errors, the Field Survival Indexes

were determined for 23 winter wheat, 13 rye, 5 triticale and 11 winter barley cultivars to estimate the winter survival potential of a cultivar in Finnish condition. The winter survival of the studied species correlated well with their hardening ability studied using the electrolyte leakage method.

Key words: conductivity, field survival index, ion leakage, Hordeum vulgare, Secale cereale, triticale, Triticum aestivum, winter hardiness 


\section{INTRODUCTION:}

The ability to survive under field conditions is often considered the ultimate measure of the winter hardiness of a cultivar (FOWLER et al. 1981). However, field trials often fail to provide reliable information as to the winter hardiness of cultivars, either because of complete winterkill or the lack of it. Even when differential winterkill does occur within a trial, it is often irregular leading to high experimental errors (FOWLER 1979). Because of this, small but important differences in the winter hardiness between cultivars may remain undetected.

In order to overcome these problems FOWLER and GUSTA (1979) developed the Field Survival Index (FSI), for the estimation of the winter hardiness potentials of winter wheat cultivars. These FSI values were later used by FOWLER (1979) in the development of the field stress contour map and by FOWLER et al. (1981) and BRULE-BABEL and FOWLER (1989) in the study of the usefulness of different physiological and morphological characters of winter wheat, and the freezing tests in screening for the winter hardiness. Using the same method, McINTYRE et al. (1988) calculated the FSIs for winter wheat and triticale breeding lines and used them in screening for the physiological traits of winter wheat and triticale associated with winter hardiness.

The electric conductivity method, also known as the ion leakage method, was introduced into frost hardiness research by DEXTER et al. $(1930,1932)$. This method is based on the assumption that during frost damage, cell membranes lose their semipermeability and ions are leaked from the cells into the effusate. Accordingly, the greater the damage to a plant, the higher the conductivity value of the effusate.

Accordingly, the objectives of the present study were: (1) to examine the progression of hardening in winter wheat, rye, triticale and winter barley cultivars in field conditions during the autumn using the conductivity method (HÖMMÖ 1992), and (2) to determine the Field Survival Indexes in Finnish conditions for 23 winter wheat, 13 rye, 5 triticale and 11 winter barley cultivars and establish the correlations between the hardening ability and the field survival ability of the experimental cultivars. The correlations with freezing tests were also determined. 
MATERIALS AND METHODS:

Field trials:

The present field trials consisted of 24 (22 in 1989-90) winter wheat, 13 (11 in 1989-90) winter rye, 5 winter triticale and 11 (10 in 1989-90) winter barley cultivars. The experimental cultivars and their origins are presented in Table 2.

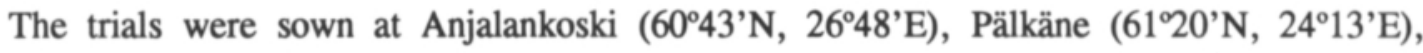
Laukaa $\left(62^{\circ} 20^{\prime} \mathrm{N}, 26^{\circ} 10^{\prime} \mathrm{E}\right)$ and Sotkamo $\left(64^{\circ} 06^{\prime} \mathrm{N}, 28^{\circ} 20^{\prime} \mathrm{E}\right)$ in 1989 , and also at Jokioinen $\left(60^{\circ} 49^{\prime} \mathrm{N}, 23^{\circ} 30^{\prime} \mathrm{E}\right)$ and Mietoinen (6038'N, 21'51'E) in 1990 and 1991. The trials were carried out as described by HÖMMÖ (1993).

The field trials were part of the Inter-Nordic "Winterhardiness" Project. Within the framework of this project the same winter wheat, rye, triticale and winter barley cultivars were tested during the same years in all Nordic countries at a total of 17 locations. The field test results collected by Dr. Kurt Hjortsholm were kindly provided for use in this study. In this data the trials were divided into two groups on the basis of the assumed main stress factor, either snow or frost, and the winter survival of the cultivars was determined within each group.

\section{Conductivity measurements:}

In the autumns of 1990 and 1991, the progression of hardening in 13 (12 in 1990) winter wheat, 10 (8 in 1990) rye, 3 (none in 1990) triticale and 6 (5 in 1990) winter barley cultivars was studied employing the conductivity method described by HÖMMÖ (1992). Leaf samples were collected from the field once a week in autumn 1990 between the 9th of October and the 20th of November, and every second week in 1991 between the 23th of September and the 19th of November. The frost treatment of leaf segments and the following conductivity determinations of the effusate, as well as the determination of indexes for frost injury, calcium and potassium, were carried out as described by HÖMMÖ (1992). In 1991 calcium and potassium were determined in only some samples.

Field Survival Index:

The field survival index for the cultivars employed was determined according to the method developed by FOWLER \& GUSTA (1979) with some modifications.

At first the differences in the winter survival of the cultivars compared to the most winter hardy one within each replicate were calculated. Only those trials were accepted where the differences between cultivars were statistically significant on the basis of analysis of variance. The 
differences were averaged for all of the trials and the cultivars ranked according to their relative winter hardiness. The least winter hardy cultivar was given the estimated FSI value (X) 50 and the differences were added to this to obtain the respective values for all cultivars. Since the stress factors varied in their intensity at each test location, the initial FSI values (X) were utilized to obtain estimates of the level of winter hardiness required to yield undamaged stands (P). $\mathrm{P}=\mathrm{X}+100-\mathrm{a}$, where $\mathrm{a}$ is the actual percent survival of the cultivar in the plot. The appropriate stress value $(C)$ for the area in which the plot was situated was then determined by calculating the sum of $\mathrm{P}$ of the plot in question and that of the two adjacent plots on either side and dividing by 3 . The FSI's for each plot were then recalculated $(\mathrm{E})$ by the formula $\mathrm{E}=\mathrm{C}$ $100+a$. Plots with $100 \%$ or $0 \%$ survival were also utilized, but only if the corrected survival index (E) was neither lower (in the case of $100 \%$ survival) nor higher (0\% survival) than that initially estimated $(\mathrm{X})$. The final mean FSI for each cultivar was then recalculated utilizing the FSI data (E-values) obtained from all of the trials.

\section{Freezing tests:}

The plants employed for the freezing tests were cultivated either in plastic boxes filled with peat-soil or in beakers containing a nutrient solution (HOAGLAND \& ARNON 1938). The freezing test was carried out as described by HÖMMÖ (1993). The minimum temperatures used were $-16,1^{\circ} \mathrm{C}$ for rye, winter wheat and triticale and $-11^{\circ} \mathrm{C}$ for winter barley.

The correlations between the hardening ability and survival rates of the cultivars were determined as well as the correlations between the FSI values and mean survival abilities of the cultivars in Finland and in the Inter-Nordic trials. As the winter wheat variety 'Vitus' is similar to spring wheats in its ability to harden, it was excluded from the correlation analysis.

\section{RESULTS:}

During the hardening period in the autumns of 1990 and 1991 the frost tolerance of all the experimental cultivars increased, which was expressed as a decrease in both the conductivity and the amount of calcium and potassium ion leaked in the effusate (Table 1). In 1990, the first samples were collected quite late in the autumn and at that time even the winter wheat cultivars seemed to be quite frost resistant. The results from the year 1990 trials are presented in more detail by HÖMMÖ (1992). In 1991, the first samples were collected already at the end of September, and on the basis of the high injury index and calcium and potassium index values, the hardening of all species had just begun (Table 1). 
The winter wheat cultivars appeared to harden somewhat faster than the rye, triticale and winter barley cultivars, but the varietal differences were considerable (Tables 1). Some of the most winter hardy Finnish cultivars, e.g. the winter wheat variety, 'Linna', and rye cultivars, 'Jussi' and 'Voima', seemed to harden quite late in the autumn, while some of the Canadian and Russian cultivars: 'Norstar', 'Albidom 12', 'Kharkov 22 MC', 'Prima' and 'Musketeer' appeared to harden much faster and earlier in the autumn (Table 1). In 1990, even the least winter hardy winter wheat cultivar, 'Vitus', attained good frost resistance, but in 1991 it was almost completely unable to harden. The most winter hardy triticale cultivar, 'Sv 856003', seemed to harden quite like the medium winter hardy winter wheat and rye cultivars, while 'Uno' with extremely poor winter hardiness resembled the least winter hardy wheat cultivars in this respect. The winter barley cultivars seemed unable to harden to the same level of frost resistance as the other species in neither of the experimental years. The most winter hardy barley cultivar was 'Borwina'. The differences in the order of the cultivars were small, whether the total means of survival rate or the field survival indexes were used (Table 2).

The hardening ability of the present cultivars in the end of October and in the beginning of November correlated best with their final winter survival (Table 3). In November, the plants reached their maximum hardiness, the differences among the cultivars were small (Table 1) and the correlations with the final winter survival results were nonsignificant. In autumn 1991, the weather was rather mild until the beginning of December and slugs caused substantial damage to plants. This might have caused some errors in the conductivity measurements, since some of the used leaf segments were already partially damaged. Both experimental winters were very mild at Jokioinen, which might explain the lack of correlation between the hardening abilities of the cultivars and their winter survival (Table 3).

Potassium ions leak from cells more easily than calcium ions. Because of this, in most cases the potassium indexes correlated better with the winter survival of the cultivars than the calcium indexes.

The hardening ability of the cultivars appeared to correlate quite well with their frost resistances as determined in controlled conditions (Table 3). The correlations were also more significant in those Inter-Nordic trials where frost was considered a more important stress factor than snow. The FSI values correlated somewhat better with the results of freezing tests and the results from the Inter-Nordic trials than the mean survival rates of the cultivars (Table 4). 


\section{DISCUSSION:}

It is generally agreed that cell plasma membranes are the primary sites of freezing injury, and the changes in the chemical composition of the membranes during cold acclimation are of crucial importance to the frost tolerance of a cultivar (PALTA 1989). As a result of freezing injury, the semipermeability of the plasma membrane is disrupted, and ions as well as sugars leak from the damaged cells.

During the hardening period in the autumns of 1990 and 1991, the frost tolerance of all of the experimental winter wheat, rye, triticale and winter barley cultivars increased, which was expressed as a decrease in the conductivity and in the amount of calcium and potassium ions leaked in the effusate. The hardening of winter wheat cultivars seemed to proceed somewhat faster than that of winter rye, triticale and winter barley, however, considerable varietal differences were observed. The most winter hardy Finnish cultivars seemed to harden much later in the autumn than some Canadian and Russian cultivars, which are considered to be very winter hardy in Canadian conditions (FOWLER and GUSTA 1979). On the other hand, the overwintering of the Finnish winter wheat cultivars, 'Linna' and 'Vakka', was only moderate in Canadian winter conditions (ANDREWS et al. 1986, BRUEHL 1982). The reason for this might be that the Finnish cultivars are adapted to a longer hardening period and different day length requirements during hardening, and they were not able to reach full hardiness in Canadian conditions.

The winter wheat and rye cultivars seemed to attain to quite the same frost hardiness level during the autumn, but the use of only one freezing program for all of the experimental species might have concealed some of the differences between them. According to FOWLER et al. (1981), freezing tests employing only one single minimum temperature correlate well with field trials only when cultivars with a wide range of winter hardiness are used. The use of leaf segments instead of the crowns of the plants might have also obscured some differences in the frost resistance, since according to LIMIN and FOWLER (1985) the cold hardiness of different parts of a plant is dissimilar. The most winter hardy triticale cultivars were similar to the medium winter hardy winter wheat and rye cultivars, while most of the triticale cultivars resembled the least winter hardy wheats. The winter barley cultivars were unable to harden to the same level of frost resistance as the other species. The winter hardiness of studied species is in accordance with the results of FOWLER and LIMIN 1987.

According to PALTA et al. (1977) potassium is the main ion present in the effusate. In this study, the potassium ion leakage at the beginning of the hardening period in rye leaves was 
about 10 times that of calcium ions and in winter barley the ratio was about 20:1. Potassium index values also correlated better with the winter survival.

In the majority of cases, the hardening ability of cultivars correlated better with those InterNordic trials in which frost was considered to be the more important stress factor than snow. Quite high correlations were also found between the hardening of the cultivars and their frost resistance as tested in the freezing tests. This finding indicates that the changes that occur during the hardening process primarily enhance the frost tolerance of plants. The reason for only moderate correlations between the hardening of the present cultivars and their final winter survival might be in that hardening may selectively promote resistance to only certain winter stress factors (such as frost) and only slightly affect the others.

The Field Survival Indexes correlated well with the results from the Inter-Nordic field trials. The correlations were more significant with those trials in which snow was more important as a stress factor than frost. Since the FSI values of the cultivars are based on their winter hardiness potential in relation to other cultivars grown in Finnish conditions, they could serve as standards for studying the morphological and physiological factors affecting the winter hardiness of cultivars in our northern conditions.

ACKNOWLEDGEMENTS: The author thanks Professor Seppo Pulli, for initiating the InterNordic Winterhardiness Project, which made this study possible. Sincere thanks are due to Miss Marja-Leena Manninen, Miss Pia Kallio and Mr. Yrjö Karppinen for technical assistance and Mrs Randi Kumpulainen for correcting the English language. This study was financed by the Samnordic Planteforedling and the Finnish Ministry of Agriculture and Forestry.

\section{REFERENCES:}

ANDREWS, C.J., M.K. POMEROY, and W.L. SEAMAN, 1986: The response of fall-sown cereals to winter stresses in eastern Ontario. Can. J. Plant Sci. 66, 25-37.

BRUEHL, G.W. 1982: Developing wheats resistant to snow mold in Washington State. Plant Disease 66, 1090-1095.

BRULE-BABEL, A.L. and D.B. FOWLER, 1989: Use of controlled environments for winter cereal cold hardiness evaluation: controlled freeze tests and tissue water content as prediction tests. Can. J. Plant Sci. 69, 355-366.

DEXTER, S.T., W.E. TOTTINGHAM, and L.F. GRABER, 1930: Preliminary results in measuring the hardiness of plants. Plant Physiol. 5, 215-223.

,---- , and - -, 1932: Investigations of the hardiness of plants by measurement of electrical conductivity. Plant Physiol. 7, 63-78.

FOWLER, D.B., 1979: Selection for winterhardiness in wheat. II. Variation within field trials. Crop Sci. 19, 773-775.

- -, and L.V. GUSTA, 1979: Selection for winterhardiness in wheat. I. Identification of genotypic variability. Crop sci. 19, 769-772. 
- -, - -, and N.J. TYLER, 1981: Selection for winterhardiness in wheat. III. Screening methods. Crop Sci. 21, 896-901.

- -, and A.E. LIMIN, 1987: Exploitable genetic variability for cold tolerance in commercially grown cereals. Can. J. Plant Sci. 67, 278.

HOAGLAND,D.R., and D.I. ARNON, 1938: The waterculture method for growing plants without soil. Calif. Agr. Exp. Sta. Cir. 347, 39p.

HÖMMÖ, L. M., 1992: Hardening ability of some winter wheat, winter rye and winter barley varieties. Use of conductivity method in evaluating the hardening ability of overwintering crop species. Norwegian J. Agric. Sci. 7 (Suppl.), 39-50.

- -, 1993: Screening winter rye varieties for snow mould (Microdochium nivale) resistance. Plant Pathol. (in press).

LIMIN, A.E., and D.B. FOWLER, 1985: Cold-hardiness response of sequential winter wheat tissue segments to differing temperature regimes. Crop Sci. 25, 838-843.

McINTYRE, B.L., T.H.H. CHEN, and M.F. MEDERICK, 1988: Physiological traits associated with winter survival of winter wheats and winter triticales in Alberta. Can. J. Plant Sci. 68, 361-366.

PALTA, J.P., 1989: Plasma membrane ATPase as a key site of perturbation in response to freeze-thaw stress. Current Topics in Plant Biochem. and Physiol. 8, 41-68.

- -, J. LEWITT, and E.J. STADELMANN, 1977: Freezing injury in onion bulb cells. I. Evaluation of the conductivity method and analysis of ion and sugar efflux from injured cells. Plant Physiol. 60, 393-397. 
Table 1. Injury Indexes and Indexes for leaked calcium and potassium ions for winter wheat, rye, triticale and winter barley cultivars in autumn 1991. nd=not done.

\begin{tabular}{|c|c|c|c|c|c|c|c|c|c|}
\hline & & 3. -25 . & 9. & & 2. -24 . & 10. & & .11 & \\
\hline & Injury & $\mathrm{Ca}^{2+}$ & $\mathrm{K}^{+}$ & Injury & $\mathrm{Ca}^{2+}$ & $\mathbf{K}^{+}$ & Injury & $\mathrm{Ca}^{2+}$ & $\mathrm{K}^{+}$ \\
\hline Winter wheat & & & & & & & & & \\
\hline Linna & 94.6 & 47.0 & 97.3 & 41.7 & 36.5 & 45.2 & 12.7 & 8.9 & 7.7 \\
\hline Vakka & 90.5 & nd & nd & 12.9 & nd & nd & 5.9 & nd & nd \\
\hline Albidom 12 & 24.6 & 12.2 & 24.2 & 1.0 & 12.1 & 19.8 & 1.2 & 5.7 & 0.0 \\
\hline Aura & 91.0 & 67.8 & 100.3 & 6.9 & 13.2 & 9.6 & 0.0 & 3.4 & 0.0 \\
\hline Norstar & 78.8 & 48.9 & 85.4 & 5.1 & 24.9 & 5.4 & 0.0 & 4.9 & 0.0 \\
\hline Rida & 87.9 & nd & nd & 43.3 & nd & nd & 0.9 & nd & nd \\
\hline Mironovskaja 808 & 892.0 & nd & nd & 34.4 & nd & nd & 12.5 & nd & nd \\
\hline Kharkov $22 \mathrm{MC}$ & 71.4 & nd & nd & 7.6 & nd & nd & 1.9 & nd & nd \\
\hline Holme & 89.4 & 67.2 & 95.2 & 84.1 & 42.4 & 79.8 & 18.2 & 8.4 & 14.9 \\
\hline Frederick & 86.0 & nd & nd & 36.4 & nd & nd & 6.5 & nd & nd \\
\hline Goertzen 5559 & 87.7 & nd & nd & 24.1 & nd & nd & 1.6 & nd & nd \\
\hline Longbow & 96.9 & 53.7 & 102.9 & 84.9 & 45.8 & 65.4 & 17.2 & 9.5 & 17.7 \\
\hline vitus & 91.2 & 46.3 & 92.9 & 98.8 & 44.6 & 71.5 & 89.1 & 85.6 & 91.3 \\
\hline Rye & & & & & & & & & \\
\hline Jussi & 78.6 & nd & nd & 13.2 & nd & nd & 4.5 & nd & nd \\
\hline Voima & 85.5 & nd & nd & 10.2 & nd & nd & 1.3 & nd & nd \\
\hline Anna & 92.0 & 49.6 & 102.9 & 6.5 & 5.9 & 5.5 & 1.6 & 28.6 & 3.8 \\
\hline Norderåstetra & 89.3 & nd & nd & 31.7 & nd & nd & 5.8 & nd & nd \\
\hline Talovskaja 12 & 91.7 & 37.0 & 136.4 & 12.2 & 15.4 & 16.3 & 3.1 & 21.4 & 5.8 \\
\hline vågonäs höstråg & 93.7 & nd & nd & 27.4 & nd & nd & 3.4 & nd & nd \\
\hline Danko & 78.2 & 29.2 & 95.5 & 23.9 & 12.1 & 31.9 & 5.7 & 21.3 & 8.2 \\
\hline Prima & 56.8 & nd & nd & 1.5 & nd & nd & 0.6 & nd & nd \\
\hline Petkus II & 87.5 & 44.2 & 146.0 & 23.2 & 7.4 & 34.7 & 9.6 & 41.2 & 16.1 \\
\hline Musketeer & 43.3 & nd & nd & 5.7 & nd & nd & 1.1 & nd & nd \\
\hline Triticale & & & & & & & & & \\
\hline Sv 856003 & 88.8 & 42.6 & 92.2 & 18.4 & 33.2 & 32.5 & nd & nd & nd \\
\hline Uno & 100.0 & nd & nd & 96.7 & nd & nd & nd & nd & nd \\
\hline Dagro & 95.0 & 56.8 & 108.8 & 32.3 & 27.9 & 32.4 & nd & nd & nd \\
\hline Winter barley & & & & & & & & & \\
\hline Borwina & 92.7 & 51.4 & 65.2 & 46.2 & 44.2 & 56.7 & 48.1 & nd & nd \\
\hline Frost & 98.0 & nd & nd & 56.7 & nd & nd & 84.0 & nd & nd \\
\hline Marinka & 87.9 & 55.3 & 90.9 & 73.0 & 51.7 & 76.5 & 60.8 & nd & nd \\
\hline Lady & 89.2 & nd & nd & 70.4 & nd & nd & 56.7 & nd & nd \\
\hline Igri & 100.0 & nd & nd & 89.0 & nd & nd & 79.8 & nd & nd \\
\hline Maris Otter & 89.7 & 54.1 & 121.7 & 96.61 & 108.9 & 51.6 & 85.6 & nd & nd \\
\hline
\end{tabular}




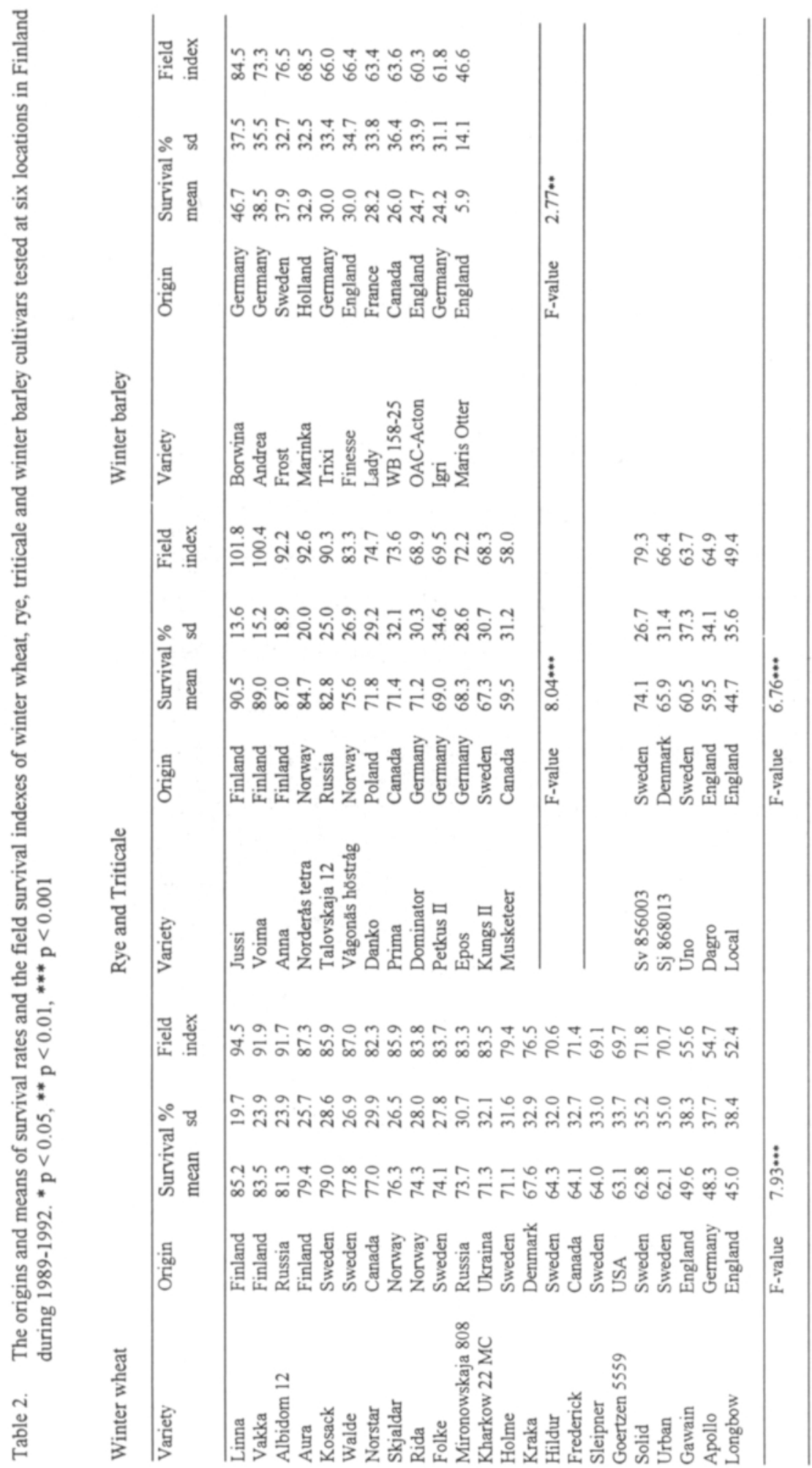


Table 3. Correlations between the injury index (I), calcium index (Ca), potassium index $(\mathrm{K})$ and the survival $\%$ of winter wheat, rye and winter barley cultivars at Jokioinen, in Finnish trials (FINtot), and in the freezing test (Surliq and Surpeat), the Field Survival Index (FSI) and the survival in the Inter-Nordic trials (Nor) with frost or snow as the main stress factor. and the total (Nortot). * p< $0.05, * * p<0.01$ and $\star \star \star \mathrm{p}<0.001$.

\begin{tabular}{|c|c|c|c|c|c|c|c|c|}
\hline & Jokioinen & FINtot & FSI & Norfrost $N$ & Norsnow & Nortotal & Surliq & Surpeat \\
\hline \multicolumn{9}{|c|}{ Winter wheat } \\
\hline \multicolumn{9}{|c|}{$\begin{array}{l}9.10 .1990 \\
n=11\end{array}$} \\
\hline I & -0.38 & $-0.75 \star \star$ & $-0.73 \star \star$ & $-0.66 *$ & $-0.76 * \star$ & $-0.71 \star$ & $-0.84 \star \star \star$ & $-0.87 \star \star \star$ \\
\hline $\mathrm{Ca}$ & -0.26 & -0.59 & -0.56 & -0.52 & $-0.62 \star$ & -0.57 & $-0.80 \star \star$ & $-0.88 \star \star \star$ \\
\hline K & -0.43 & $-0.78 \star \star$ & $-0.76 \star \star$ & $-0.69 \star$ & $-0.79 \star \star$ & $-0.74 \star \star$ & $-0.81 \star \star$ & $-0.84 \star \star \star$ \\
\hline \multicolumn{9}{|c|}{22.10 .1991} \\
\hline $\mathrm{n}=1$ & I and $n=6$ & in $\mathrm{Ca}$ and & K & & & & & \\
\hline I & -0.13 & $-0.60 *$ & $-0.59 \star$ & $-0.68 \star \star$ & $-0.60 \star$ & $-0.62 \star$ & -0.37 & $-0.90 \star \star \star$ \\
\hline $\mathrm{Ca}$ & -0.45 & -0.62 & -0.62 & -0.72 & -0.60 & -0.64 & -0.40 & $-0.86 \star$ \\
\hline $\mathrm{K}$ & -0.09 & -0.53 & -0.50 & -0.65 & -0.53 & -0.55 & -0.34 & $-0.89 \star \star$ \\
\hline \multicolumn{9}{|c|}{ Rye } \\
\hline \multicolumn{9}{|c|}{$25.10 \cdot 1990$} \\
\hline I & -0.62 & -0.45 & -0.47 & $-0.68 *$ & -0.44 & -0.58 & 0.17 & 0.33 \\
\hline $\mathrm{Ca}$ & $-0.86 * *$ & $-0.79 *$ & $-0.83 \star \star$ & -0.45 & $-0.73 \star$ & $-0.81 \star \star$ & 0.24 & 0.17 \\
\hline K & -0.47 & -0.35 & -0.37 & $-0.71 \star$ & -0.40 & -0.53 & 0.09 & 0.15 \\
\hline \multicolumn{9}{|c|}{22.10 .1991} \\
\hline I & -0.11 & 0.05 & 0.09 & -0.65 & -0.07 & -0.14 & -0.14 & -0.26 \\
\hline $\mathrm{Ca}$ & -0.22 & -0.00 & 0.14 & -0.21 & -0.02 & -0.08 & 0.16 & $-0.89 \star$ \\
\hline K & -0.54 & $-0.99 \star \star$ & $-0.96 \star \star$ & $-0.99 \star \star \star$ & $-0.99 \star \star \star$ & $-0.99 \star \star \star$ & 0.18 & 0.24 \\
\hline \multicolumn{9}{|c|}{ Winter barley } \\
\hline \multicolumn{9}{|c|}{$\begin{array}{l}1.11 \cdot 1990 \\
n=5\end{array}$} \\
\hline I & $-0.94 \star \star$ & $-0.84 \star$ & $-0.86 \star$ & $-0.92 \star \star$ & $-0.85 \star$ & $-0.86 *$ & $-0.85 \star$ & $-0.87 \star$ \\
\hline $\mathrm{Ca}$ & -0.49 & -0.34 & -0.41 & -0.46 & -0.35 & -0.36 & $-0.91 \star$ & -0.69 \\
\hline K & -0.76 & -0.74 & -0.68 & -0.77 & -0.74 & -0.75 & -0.50 & -0.45 \\
\hline \multicolumn{9}{|c|}{ 24.10. 1991} \\
\hline \multicolumn{9}{|c|}{$\mathrm{n}=6$ in $\mathrm{I}$ and $\mathrm{n}=3$ in $\mathrm{Ca}$ and $\mathrm{K}$} \\
\hline I & $-0.83 \star$ & $-0.94 \star \star$ & $-0.95 \star \star \star$ & $-0.94 \star \star$ & $-0.94 \star \star$ & $-0.94 \star \star$ & -0.41 & $-0.81 \star$ \\
\hline $\mathrm{Ca}$ & $-0.99 * \star$ & $-0.97 \star$ & -0.95 & -0.92 & $-0.96 \star$ & $-0.96 \star$ & -0.45 & -0.95 \\
\hline K & -0.64 & -0.37 & -0.28 & -0.21 & -0.31 & -0.32 & -0.47 & 0.28 \\
\hline
\end{tabular}


Table 4. Correlations between total means of winter survival of winter wheat, rye, triticale and winter barley cultivars in field trials (Fintotal), Field Survival Index (FSI) and survival in InterNordic trials with frost (Norfrost), or snow (Norsnow) as the main stress factor and the total (Nortotal) and frost tolerance of cultivars tested in nutrition solution (Surliquid) and peat-soil mixture (Surpeat). * $\mathrm{p}<0.05, * * \mathrm{p}<0.01$ and $* \star * \mathrm{p}<0.001$.

\begin{tabular}{|c|c|c|c|}
\hline & Trait & Fintotal & FSI \\
\hline Winter wheat & Norfrost & $0.91 \star \star \star$ & $0.92 \star \star \star$ \\
\hline \multirow[t]{4}{*}{$\mathrm{n}=23$} & Norsnow & $0.99 * \star \star *$ & $0.99 \star \star \star \star$ \\
\hline & Nortotal & $0.98 \star \star \star *$ & $0.98 * \star \star$ \\
\hline & Surliquid & $0.52 \star \star$ & $0.52 \star \star$ \\
\hline & Surpeat & $0.62 \star \star$ & $0.62 \star \star \star$ \\
\hline Rye & Norfrost & 0.22 & 0.26 \\
\hline \multirow[t]{4}{*}{$n=13$} & Norsnow & $0.88 * \star \star$ & $0.87 \star \star \star *$ \\
\hline & Nortotal & $0.86 * \star \star$ & $0.86 * \star \star *$ \\
\hline & Surliquid & 0.17 & 0.23 \\
\hline & Surpeat & -0.20 & -0.21 \\
\hline Triticale & Surliquid & 0.32 & 0.40 \\
\hline$n=5$ & Surpeat & $0.75 * \star$ & $0.78 * \star$ \\
\hline Winter barley & Norfrost & $0.88 * \star \star *$ & $0.88 * \star \star$ \\
\hline \multirow[t]{4}{*}{$\mathrm{n}=11$} & Norsnow & $0.99 * \star \star *$ & $0.99 \star \star \star *$ \\
\hline & Nortotal & $0.98 * \star \star *$ & $0.97 \star \star \star *$ \\
\hline & Surliquid & 0.32 & 0.40 \\
\hline & Surpeat & $0.75 \star \star$ & $0.78 \star \star$ \\
\hline
\end{tabular}



ACCUMULATION OF DRY MATTER AND SUGAR AND CHANGES IN PLASMA MEMBRANE FATTY ACIDS IN TWO WINTER WHEAT (Triticum aestivum

L.) CULTIVARS WITH DIFFERENT WINTER HARDINESS ABILITIES

Leena Hömmö

Agricultural Research Centre of Finland

Institute of Plant Breeding

FIN-31600 Jokioinen, Finland

Running title: Metabolic changes during hardening

Date of Submission: 21.10.1993 


\section{ABSTRACT}

Two winter wheat cultivars with different winterhardiness abilities were studied for their accumulation of dry matter and sugars and for changes in plasma membrane lipids and fatty acid compositions during a five-week cold acclimation.

Although the freezing resistance of the cultivars differed, they were equally effective in the accumulation of dry matter in their roots and green parts. The winter hardy cultivar 'Linna' accumulated more raffinose, sucrose, glucose and fructose than the susceptible cultivar 'Apollo', while 'Apollo' synthesized more energy reserves in the form of fructans during cold acclimation. In non-hardened plants the sucrose, glucose and fructose contents were higher in 'Apollo' than in 'Linna'.

The relative content of unsaturated fatty acids increased in both cultivars during hardening, but in non-hardened plants the content of unsaturated fatty acids was higher in the hardy cultivar 'Linna'. The relative contents of linoleic and linolenic acids increased and the palmitic acid content decreased in the phospholipid fraction. The behenic acid content increased more in the winter hardy cultivar than in the susceptible one. In the neutral lipid and glycolipid fractions the stearic acid content increased distinctly in 'Linna', but only moderately in 'Apollo'.

Key words: cold acclimation, fatty acids, plasma membranes, sugars, Triticum aestivum, 


\section{INTRODUCTION}

Overwintering plants have the ability to change their metabolic processes $(=$ cold acclimate) during autumn or when artificially exposed to sub-freezing temperatures (Levitt, 1980; Steponkus, 1978).

Physiological changes which promote freezing resistance include modifications in gene expression (Cattivelli and Bartels, 1989; Dhindsa et al., 1993; Thomashow, 1990) and in the patterns of soluble proteins (Cloutier, 1983; Griffith et al., 1993; Marentes et al., 1993; Perras and Sarhan, 1989). Increased contents of free amino acids (especially proline), abscisic acid (ABA), soluble sugars and dry matter have also been connected to enhanced freezing resistance (Charest and Phan, 1991; Dörffling et al., 1990; Gilmour and Thomashow, 1991; Green and Ratzlaff, 1975; Lång et al., 1989; Larsson et al., 1992; Robertson et al., 1993).

Cell plasma membranes are considered to be the primary sites of freezing injury (Steponkus, 1978; Palta, 1989; Palta and Weiss, 1993). During cold acclimation, the plasma membrane composition is changed to allow the lowering of the liquid-crystalline- to gel-phase transition temperature of the membranes (Steponkus et al., 1990). These changes have been associated with the increase of plasma membrane lipids (especially in the phopholipid fraction) and with the increased unsaturation of fatty acids (Aro et al., 1987; De La Roche et al., 1973; Levitt, 1980; Palta and Weiss, 1993; Sakai and Larcher, 1987; Siminovitch et al., 1978; Singh and Laroche, 1988; Steponkus, 1978; Sutinen et al., 1989). According to Lynch and Steponkus (1987), cold acclimation induces substantial changes in virtually all lipid fractions of the plasma membranes. On the contrary to this, Hellergren et al. (1984), Uemura and Yoshida (1984) and Yoshida and Uemura (1984) found only slight differences in the plasma membrane lipid composition of Pinus sylvestris, Secale cereale and Dactylis glomerata, respectively, during cold acclimation.

The present study aimed to clarify if the accumulation of dry matter and various sugars during a five-week cold acclimation period differed in two winter wheat (Triticum aestivum L.) cultivars, 'Linna' and 'Apollo', with very different winter survival abilities. In addition, changes in the plasma membrane lipid and fatty acid compositions were determined.

\section{MATERIALS AND METHODS}

\section{Plant materials}

Two winter wheat cultivars, 'Linna' (Finnish origin) and 'Apollo' (German origin) were used 
in all analyses. Seedlings for the freezing tests and plasma membrane fatty acid analysis were grown in a nutrient solution (Hoagland and Arnon, 1938) and those for the sugar analysis in a fertilized sand culture. The plants were cultivated in greenhouse conditions $\left(+20^{\circ} \mathrm{C} /+10^{\circ} \mathrm{C}\right.$, 18/6h photoperiod and $12000 \mathrm{lux}$ ) until the two leaf stage. The plants were hardened in a cold chamber $\left(+2^{\circ} \mathrm{C}, 16 / 8 \mathrm{~h}\right.$ photoperiod, $\left.10000 \mathrm{lux}\right)$. The freezing resistance of the cultivars, their dry matter contents, plasma membrane fatty acids and leaf and root sugar contents were determined once a week just before hardening and after 1, 2, 3, 4 and 5-week hardening periods.

\section{Freezing tests}

Freezing tests were carried out as described by Larsson (1983) with some modifications. The duration of the freezing procedure was $72 \mathrm{~h}$ and the lowest temperature during the program was $-12^{\circ} \mathrm{C}(32 \mathrm{~h})$. During the test the roots of the plants were covered with moistened tissue paper. After the frost treatment the plants were kept at $+2^{\circ} \mathrm{C}$ in darkness for 24 hours. The amount of visual frost damage on the plants was assessed after two days using the score of 0 (dead plant) to 5 (no visual damage) and the final survival rate after a five-day recovery period in the greenhouse. The results present the means of two replicates.

\section{Plasma membrane fatty acids}

The enriched plasma membrane fraction was obtained from 'Linna' and 'Apollo' seedlings using the two-phase partition system of polyethylene glycol/dextran T 500 described by Larsson (1985), with only minor modifications. Leaf segments of $50 \mathrm{~g}$ from both cultivars were used in the analysis and the two-phase partition system at a final concentration of $6.5 \% / 6.5 \%(w / w)$ polyethylene glycol/dextran in a solution of $0.33 \mathrm{M}$ sucrose, $3 \mathrm{mM} \mathrm{KCl}, 5 \mathrm{mM} \mathrm{K}_{2} \mathrm{HPO}_{4}(\mathrm{pH}$ 7.8) was the most suitable one for winter wheat. (The phase systems 5.6\%/5.6\%, 5.9\%/5.9\%, $6.2 \% / 6.2 \%, 6.5 \% / 6.5 \%$ and $6.8 \% / 6.8 \%(\mathrm{w} / \mathrm{w})$ were comparitively studied, to determine which one was the most efficient one). To simplify the phase separation procedure, only the upper phases, containing most of the plasma membranes, were used in the subsequent purifications.

The total lipids from the resulting pale-coloured pellets (no green chlorophyll), consisting of the plasma membrane fractions, were extracted using the method of Bligh and Dyer (1959). The lipid extracts were separated into neutral lipid, glycolipid and phospholipid fractions on silica Sep Pak cartridges (Millipore) using the procedures based on Hamilton and Comai (1984) and modified by Lynch and Steponkus (1987). The fatty acid methyl esters from the resulting 
lipid fractions I (neutral lipids), II (glycolipids) and III (phospholipids) were prepared according to Metcalfe and Schmitz (1961) and determined using a Perkin-Elmer Model 8420 gas chromatograph equipped with a $30 \mathrm{~m} \times 0.75 \mathrm{~mm}$ Supelcowax ${ }^{\mathrm{m}} 10$ capillary column. The operating conditions were: injector temperature $290^{\circ} \mathrm{C}$, detector temperature $290^{\circ} \mathrm{C}$ and column temperature $205^{\circ} \mathrm{C}$ during the run and $205-240^{\circ} \mathrm{C}$ (rate of increase $15^{\circ} \mathrm{C} / \mathrm{min}$ ) in the cleaning between samples. The carrier gas was hydrogen. The relative contents of individual fatty acids were determined as percentages of the total fatty acids.

\section{Carbohydrate determinations}

The carbohydrate contents were determined in the green parts of the plants (leaves and crowns above the soil) and in the roots. Sand was removed from the roots with cold tap water, and both the leaves and the roots were dried in a forced air oven at $+80^{\circ} \mathrm{C}$ for $24 \mathrm{~h}$. The green parts and the roots of the plants were weighed before and after drying and the dry matter content was determined in percent of the fresh matter. The samples were ground in a GWB Culatti (DCFH48) mill, and frozen at $-18^{\circ} \mathrm{C}$. All carbohydrate determinations were replicated twice and the results are the means of the replications.

The total nonstructural carbohydrates were determined in $200 \mathrm{mg}$ of the dried samples using the Weinmann Method (Weinmann, 1947), modified by Smith (1969). Starch and disaccharides were hydrolyzed with $0.5 \%$ takadiastase enzyme, and fructans with $1 \mathrm{~N}_{2} \mathrm{SO}_{4}$. The reducing power of the resulting monomers was determined using the Shaeffer-Somogyi copper- iodometric titration method described by Heinze and Murneek (1940) and the carbohydrate contents were expressed in percent/dry weight.

The contents of ethanol-soluble carbohydrates were also determined. Two hundred $\mathrm{mg}$ of the dried sample was extracted for $2 \mathrm{~h}$ at $150^{\circ} \mathrm{C}$ in a Tecator reflux apparatus using $90 \%$ ethanol as the extractant. The solution was filtered through MN 616 filter paper and ethanol was evaporated from the solution. After adding distilled water, the solution was refiltered (MN 616 paper), $2 \mathrm{ml}$ of $10 \%$ lead acetate was added, and the sample was made up to $100 \mathrm{ml}$ with distilled water. Monosaccharides were determined directly from this solution using the titration method, but disaccharides had to be hydrolyzed with $1 \mathrm{~N} \mathrm{H}_{2} \mathrm{SO}_{4}$ before the titration.

The changes in the contents of different ethanol-soluble sugars were studied by the method of Fretz et al. (1970). Five hundred $\mathrm{mg}$ of the dried sample was extracted using $80 \%$ ethanol as described above. One $\mathrm{ml}$ of filtered extract $+0.5 \mathrm{ml}$ myo-Inositol (an internal standard) were evaporated to dryness at $+60^{\circ} \mathrm{C}$, cooled to room temperature and silylated by the addition of $0.25 \mathrm{ml}$ anhydrous pyridine, $0.1 \mathrm{ml}$ trimethylchlorosilane (TMCS) and $0.1 \mathrm{ml}$ hexamethyldisili- 
zane (HMDS) by mixing. After 30 minutes equilibration the sugars were assayed using the Perkin-Elmer Model 8420 gas chromatograph equipped with a BP-1 capillary column (S.G.E.), $25 \mathrm{~m} \times 0.22 \mathrm{~mm}$. The oven programme started at $180^{\circ} \mathrm{C}$ and rose at $5^{\circ} \mathrm{C}$ per min to $300^{\circ} \mathrm{C}$ which was maintained for $11 \mathrm{~min}$ before cooling. The carrier gas was hydrogen.

\section{RESULTS}

\section{Frost resistance and dry matter content}

The frost resistance of both cultivars increased during the hardening period (Table 1). Frost damage on plants was estimated as the whole material, not on the single plant level. After three weeks' hardening, the first plants of the 'Linna' cultivar survived the frost treatment, while the 'Apollo' plants needed another week of hardening. Because of the low number of cultivars tested, the differences in the freezing resistance of the cultivars were statistically nonsignificant (Table 1).

The dry matter content of the leaves, crowns and roots increased in both cultivars during the hardening period (Table 2). For both cultivars the increase was about $50 \%$ in the leaves and about $110 \%$ in the roots.

\section{Plasma membrane fatty acids}

During the hardening process there was variation in the fatty acid contents of all the lipid fractions studied; neutral lipids, glycolipids and phospholipids. Generally, in both cultivars the relative total content of unsaturated fatty acids increased in the phospholipid fraction, but decreased in the neutral lipid and glycolipid fractions.

The most pronounced changes occurred during the first two weeks (Fig. 1). In most cases, the palmitic acid content decreased slightly and the oleic acid content decreased considerably. However, in the winter hardy cultivar 'Linna', the proportion of palmitic acid in the phospholipid fraction peaked after two weeks' hardening, and that in the neutral lipid fraction after four weeks' hardening. In the neutral lipid fraction there was also a peak in the relative content of oleic acid after four weeks' hardening in both cultivars. The relative linoleic acid content decreased in neutral lipids and glycolipids, but increased in the phospholipid fraction. In neutral lipids and glycolipids there was a peak in the linolenic acid content after two weeks' hardening, and a second peak in glycolipids after four weeks' hardening. The phospholipids showed only a slight increase in the relative linolenic acid content in the cultivar 'Linna', but in 'Apollo' this increase was very clear. The relative stearic acid content increased in the neutral lipid and 
glycolipid fractions, but decreased in the phospholipid fraction.

In addition to the fatty acids presented in Figure 1, also some other fatty acids were determined in the total fatty acids of the sample, whenever possible. Such fatty acids were arachic, eicosenoic, eicosadienoic, behenic and erucic acids. In 'Linna' the relative behenic acid content increased in all lipid fractions during hardening, with a clear peak in the phospholipid fraction after four weeks' hardening. In 'Apollo' the behenic acid content increased in the glycolipid fraction, but decreased in the other two fractions. There were high relative contents of eicosenoic and eicosadienoic acids in neutral lipid fraction during the first two weeks of hardening, after which their contents rapidly decreased, but in the phospholipid fraction there was a peak in the contents of these fatty acids in 'Linna' after four and in 'Apollo' after three weeks' hardening.

\section{Carbohydrates}

The total content of ethanol-soluble sugars increased in the leaves and roots of both cultivars during the cold acclimation (Fig. 2). The sucrose content increased distinctly in both cultivars during the first week of hardening (Fig. 3). During the second week the sucrose content decreased abruptly in the leaves and roots of 'Apollo' and slightly in the leaves of 'Linna'. The sucrose content in the roots of 'Linna' increased steadily throughout the entire hardening period. During the third week the sucrose content in the leaves of both cultivars increased steeply again, reaching the maximum concentration. The leaves of 'Linna' had a sucrose content of $11.7 \%$ (of dry matter) after 5 weeks of hardening. The sucrose content in the leaves of 'Apollo' (6.7 \%) matched that in the roots of 'Linna'. The sucrose content was lowest in the roots of 'Apollo', 5.0 percent of the dry matter content.

The trisaccharide raffinose content increased steadily during the hardening period in the leaves and roots of both cultivars. The final raffinose contents were highest in the leaves of 'Linna', similar in the leaves of 'Apollo' and in the roots of 'Linna' and lowest in the roots of 'Apollo'. An unknown sugar was also determined in the gas chromatogram with a retention time about half a minute after raffinose. During hardening the concentration of this sugar increased maximally from 0.6 to $3.0 \%$ (in the leaves of 'Linna') and minimally from 0.4 to $1.6 \%$ (in the leaves of 'Apollo'). This sugar was excluded from the total sugar calculations, however.

A pronounced increase in the contents of monosaccharides (glucose and fructose) occurred during the first week of hardening in the leaves and roots of 'Apollo' and during the first two weeks in 'Linna' (Fig. 4). In both cultivars this increase was followed by an abrupt decrease in the monosaccharide contents. On the whole, both the glucose and fructose contents increased 
slightly in all of the other samples, exept for in the leaves of 'Apollo', in which a slight decrease in the glucose content was observed.

The contents of fructans increased distinctly in the roots and leaves of both cultivars during the cold acclimation (Fig. 5). Fructans accumulated in greater quantities in the leaves and roots of 'Apollo' than in 'Linna'.

The starch content decreased in the leaves of both cultivars, and only slight contents were detected after three weeks of hardening (Fig. 5). There appeared to be no starch in the roots of the presently studied cultivars.

\section{DISCUSSION}

The ability of overwintering cereals to alter their metabolic processes during cold acclimation in autumn determines their winterhardiness, and thus the northern limit of their cultivation. This ability is partly inherited (Levitt, 1980), and in part dependent on the environmental conditions (temperature and light) which prevail during the hardening period (Fowler and Gusta, 1977).

Increased dry matter contents during hardening are usually associated with enhanced freezing resistance of plants (Huner et al., 1989; Keteleer et al., 1988; Krol et al., 1984; Levitt, 1980). Higher dry matter content probably results from both a decrease in the cell water content and an increase in cytoplasmic constituents (Huner et al., 1989). A distinct increase in the dry matter content of the leaves, crowns and roots was found during hardening in the two winter wheat cultivars 'Linna' and 'Apollo' also in this study. Although the freezing resistance of the German cultivar 'Apollo' was inferior to that of the Finnish cultivar, 'Linna', they did not differ in terms of the dry matter accumulation in different plant organs during the cold acclimation.

An increase in the lipid content, especially the phospholipid content, and in the unsaturation of fatty acids is usually associated with increased winterhardiness in plants (De La Roche et al., 1975; de Silva et al., 1975; Graham and Patterson, 1982; Steponkus, 1978). In most studies, however, the lipid or fatty acid composition has been determined from the total lipid extracts from whole plant tissues or from crude membrane preparations (Bulder et al., 1989; Larsson et al., 1992; Siminovitch, 1968; Sutinen et al., 1989; Vereshchagin et al., 1990; Zúñiga et al., 1990), and therefore it is possible that these results better characterize the changes which occur in all of the cell membrane systems (e.g. chloroplasts, mitochondria, endoplasmic reticulum) than the changes in the plasma membranes per se. According to Uemura and Yoshida (1984) 
and Yoshida and Uemura (1984), the phospholipid composition in purified plasma membranes changed only slightly during the hardening of winter rye and orchard grass, respectively, but the phospholipid-to-protein ratio increased by about $25 \%$ during cold acclimation. The unsaturation of fatty acids in the plasma membranes increased only slightly, but in the endomembranes there was a distinct increase in unsaturation during the hardening. On the other hand, Lynch and Steponkus (1987) found that the cold acclimation of winter rye seedlings resulted in substantial changes in the lipid composition, and in increased contents of diunsaturated molecular species of phospholipids in the plasma membranes.

In this study, the most pronounced changes in the relative contents of fatty acids in neutral lipids, glycolipids and phospholipids in the purified plasma membrane fractions of winter wheat leaves occurred during the first two weeks. Likewise, Farkas et al. (1975) found that changes in the fatty acid composition of winter wheat and rye leaves were apparent after two days of cold acclimation. According to Steponkus et al. (1990), the transformation of the cryobehaviour of rye plasma membrane is completed within the first 7-10 days of cold acclimation. They concluded that changes in the phospholipid composition of the plasma membrane (mainly an increase in the unsaturation of fatty acids) may be related to the cold acclimation process of winter rye by increasing resistance to initial stresses (freezing temperatures down to $-5^{\circ} \mathrm{C}$ ), but that these changes are not responsible for the extent of hardiness in hardier cultivars and hence do not account for differences between cultivars. Singh and Laroche (1988) proposed that some changes in the lipid composition of plasma membranes may occur in respose to the effect of low temperature on lipid biosynthesis, while others may be responsible for hardening. According to Uemura and Yoshida (1984), the relation between the unsaturation of fatty acids and cold hardiness might depend on the degree of cold hardiness (intermediate/ extreme) of a particular species.

The content of unsaturated fatty acids in the phospholipid fraction increased by about $22 \%$ in the cultivar 'Apollo' and only by about $5 \%$ in the cultivar 'Linna'. This difference is mainly due to the different contents of unsaturated fatty acids in nonacclimated plants $(49.7 \%$ in 'Apollo' and $58.3 \%$ in 'Linna'). The relative content of unsaturated fatty acids in both cultivars was $61.1 \%$ after 5 weeks' cold acclimation. The linoleic (18:2) and linolenic acid (18:3) contents increased and the palmitic acid (16:0) content decreased during cold acclimation in both cultivars. However, the linoleic and linolenic acid contents (24\% and $21 \%$, respectively) in non-hardened 'Linna' were higher than in non-hardened 'Apollo' (22\% and $18 \%$, respectively), and correspondingly, the palmitic acid content was lower (30\%) in non-hardened 'Linna' than in non-hardened 'Apollo' (37 \%). Thus, it might be possible to select the frost 
resistance of cultivars on the basis of the fatty acid composition of non-hardened plants as Larsson et al. (1992) have proposed. The behenic acid (22:0) content increased by about $23 \%$ during hardening in 'Linna', while in 'Apollo' it decreased slightly (7 \%). The content of unsaturated fatty acids decreased in the neutral lipid and glycolipid fractions. The stearic acid (18:0) content increased distinctly in all of these lipid fractions in both cultivars during the fiveweek cold acclimation. In the more winter hardy cultivar 'Linna' this increase was $108 \%$ in the neutral lipid fraction and $242 \%$ in the glycolipid fraction, and in 'Apollo' $35 \%$ and $67 \%$, respectively. Sutinen et al. (1989) also found high stearic acid contents in profoundly hardened red pine needles. The contents of linoleic and linolenic acids decreased during hardening in both lipid fractions in both of the cultivars studied.

There is ample evidence that the cell sap concentration increases during cold acclimation and that the major changes in total osmotic potential are due to changes in the concentrations of sugars (see Levitt, 1980; Sakai and Larcher, 1987). Increased sucrose concentration in the shoots and roots has most often been associated with better winterhardiness in various plant species (Keteleer et al., 1988; Kneen and Blish, 1941; Larsson et al., 1992; Levitt, 1980; Livingston et al., 1989; Santoiani et al., 1993; Volenec et al., 1991). According to Anchordoguy et al. (1987) sugars, especially sucrose and trehalose, may also enhance the freezing resistance of plants through the stabilization of plasma membranes by interaction with the polar heads of phospholipids. During the 5-week cold acclimation in this study, the sucrose content increased fourfold in the shoots and fivefold in the roots of the more winter hardy cultivar 'Linna', while the increases were twofold and threefold, respectively, in 'Apollo'. In accordance with the results of Crawford and Huxter (1977), Livingstone et al. (1989) and Pollock (1984), the increase in sucrose content at the beginning of cold acclimation was followed by a marked decrease in both cultivars. This decrease was much greater in the more frost susceptible cultivar 'Apollo'.

Monosaccharides, glucose and fructose contents also increased during the cold acclimation in all the other samples except for in the shoots of 'Apollo', where the glucose content decreased by $14 \%$. A similar decrease in the monosaccharide content as that in sucrose was found in 'Apollo' after the first week of hardening, but not in 'Linna'.

The sucrose, glucose and fructose concentrations in unhardened plants were much higher in the more sensitive cultivar 'Apollo' than in the hardier 'Linna'. Similar results have been reported by Keteleer et al. (1988) for winter barley cultivars.

At the beginning of cold acclimation the cessation of plant growth results in surplusses of photosynthates, while photosynthesis is still active. According to Livingston et al. (1989), 
Pollock (1984), Pontis (1970, 1989), Pressman et al. (1989) and Tognetti et al. (1990) the increased sucrose content triggers the synthesis of fructans, which constitute the main carbon source for spring growth in overwintering grass species (Suzuki and Nass, 1988). Fructans also have a clear role in the frost resistance of species. They adjust the osmotic pressure in cells during ice formation and act as cryoprotectants of membranes (Pontis, 1989; Suzuki and Nass, 1988). The content of fructans increased notably also in the two presently studied winter wheat cultivars during five weeks' hardening. The accumulation was more pronounced in the shoots than in the roots of the plants. This finding is in accordance with the results of Pollock (1984). The more frost sensitive cultivar 'Apollo' accumulated more fructans in both its shoots and roots than the winter hardy 'Linna'. According to Livingston et al. (1989) less winter hardy winter barley cultivars accumulated more fructan, leaving less simple sugars for cryoprotection, while winter hardy cultivars had relatively high contents of simple sugars. Thus, the German cultivar 'Apollo' transformed more monosaccharides and sucrose (contents decreased) into fructans, thereby ensuring ample energy reserves for spring growth, while the Finnish cultivar 'Linna', which is bred for severe winter conditions, left more free sugars for cellular cryoprotection.

The hydrolysis of accumulated starch into simple sugars during cold acclimation (Levitt, 1980; Sakai and Larcher, 1987) was also observed in this study. After three weeks of hardening only traces of starch were left in the shoots of both cultivars. No starch was found in the roots of any of the samples. The accumulation of trisaccharides, mainly raffinose, has also been connected with frost resistance (Gunar and Sileva, 1954; Larsson et al., 1992; Levitt, 1980). Parker (1959) found higher contents of trisaccharides (raffinose and stachyose) in the bark and leaves of six cold acclimated conifers. In this study the accumulation of raffinose and one unknown sugar (possibly stachyose) was found. Both sugars accumulated in greater amounts in the shoots and roots of the more frost resistant cultivar, 'Linna'.

\section{ACKNOWLEDGEMENTS}

The author thanks Professor Seppo Pulli, Head of the Institute of Plant Breeding, for his support during the course of this study. Sincere thanks are due to Miss Marja-Leena Manninen and Mr. Pertti Kaven for technical assistance and to Mrs. Randi Kumpulainen for correcting the English language. This study was partially financed by the Samnordic Planteforedling and the Finnish Ministry of Agriculture and Forestry. 
ANCHORDOGUY TJ, RUDOLPH AS, CARPENTER JF, CROWE JH. 1987. Modes of interaction of cryoprotectants with membrane phospholipids during freezing. Cryobiology 24, 324-331.

ARO EM, SOMERSALO S, KARUNEN P. 1987. Membrane lipids in Ceratodon purpureus protonemata grown at high and low temperatures. Physiologia Plantarum 69, 65-72.

BLIGH EG, DYER WJ. 1959. A rapid method of total lipid extraction and purification. Canadian Journal of Biochemistry and Physiology 37, 911-917.

BULDER HAM, VAN DER LEIJ WR, SPEEK EJ, VAN HASSELT PR, KUIPER PJC. 1989. Interactions of drought and low temperature stress on lipid and fatty acid composition of cucumber genotypes differing in growth response at suboptimal temperature. Physiologia Plantarum 75, 362-368.

CATTIVELLI L, BARTELS D. 1989. Cold-induced mRNAs accumulate with different kinetics in barley coleoptiles. Planta 178, 184-188.

CHAREST C, PHAN CT. 1991. Kinetic properties of four enzymes involved in proline metabolism in cold-acclimated wheat. Journal of Experimental Botany 42, 673-678.

CLOUTIER Y. 1983. Changes in the electrophoretic patterns of the soluble proteins of winter wheat and rye following cold acclimation and desiccation stress. Plant Physiology 71, 400403.

CRAWFORD RMM, HUXTER TJ. 1977. Root growth and carbohydrate metabolism at low temperatures. Journal of Experimental Botany 28, 917-925.

DE LA ROCHE JA, ANDREWS CJ, KATES M. 1973. Changes in phospholipid composition of a winter wheat cultivar during germination at $2^{\circ}$ and $24^{\circ} \mathrm{C}$. Plant Physiology 51, 468-473.

DE LA ROCHE IA, POMEROY MK, ANDREWS CJ. 1975. Changes in fatty acid composition in wheat cultivars of contrasting hardiness. Cryobiology 12, 506-512.

DE SILVA NS, WEINBERGER P, KATES M, DE LA ROCHE IA. 1975. Comparative changes in hardiness and lipid composition in two near-isogenic lines of wheat (spring and winter) grown at $2^{\circ} \mathrm{C}$ and $24^{\circ} \mathrm{C}$. Canadian Journal of Botany 53, 1899-1905.

DHINDSA RS, MONROY A, WOLFRAIM L, DONG G. 1993. Signal transduction and gene expression during cold acclimation of alfalfa. In: Li PH, Christersson L, eds. Advances in Plant Cold Hardiness. Boca Raton, Florida, USA: CRC Press, 57-71.

DÖRFFLING K, SCHULENBURG S, LESSELICH G, DÖRFFLING H. 1990. Abscisic acid and proline levels in cold hardened winter wheat leaves in relation to variety-specific differences in freezing resistance. Journal of Agronomy and Crop Science 165, 230-239.

FARKAS T, DERI-HADLACZKY E, BELEA A. 1975. Effect of temperature upon linolenic acid level in wheat and rye seedlings. Lipids 10, 331-334.

FOWLER DB, GUSTA LV. 1977. Influence of fall growth and development on cold tolerance of rye and wheat. Canadian Journal of Plant Science 57, 751-755.

FRETZ TA, DUNHAM CW, WOODMANSEE CW. 1970. A gas chromatographic procedure for determining soluble carbohydrates extracted from leaf tissue of Ilex opaca Ait. cv. 'Miss Helen'. American Horticulturist (American Horticultural Society) 95, 99-102.

GILMOUR SJ, THOMASHOW MF. 1991. Cold acclimation and cold-regulated gene expression in ABA mutants of Arabidopsis thaliana. Plant Molecular Biology 17, 1233-1240.

GRAHAM D, PATTERSON BD. 1982. Responses of plants to low, non-freezing temperatures: proteins, metabolism and acclimation. Annual Review of Plant Physiology 33, 347-372. GREEN DG, RATZLAFF CD. 1975. An apparent relationship of soluble sugars with hardiness in winter wheat varieties. Canadian Journal of Botany 53, 2198-2201.

GRIFFITH M, MARENTES E, ALA P, YANG DSC. 1993. The role of ice-binding proteins in frost tolerance of winter rye. In: Li PH, Christersson L, eds. Advances in Plant Cold 
Hardiness. Boca Raton, Florida, USA: CRC Press, 177-186.

GUNAR II, SILEVA MN. 1954. Variation of the sugar content of winter wheats during the hardening-off process. Fiziologiia Rastenii 1, 141-145.

HAMILTON JG, COMAI K. 1984. Separation of neutral lipids and free fatty acids by highperformance liquid chromatography using low wavelength ultraviolet detection. Journal of Lipid Research 25, 1142-1148.

HEINZE PH, MURNEEK AE. 1940. Comparative accuracy and efficiency in determining of carbohydrates in plant material. Missouri Agricultural Experimental Station Research Bulletin 314.

HELLERGREN J, LUNDBORG T, WIDELL S. 1984. Cold acclimation in Pinus sylvestris: Phospholipids in purified plasma membranes from needles of pine. Physiologia Plantarum 62, 162-166.

HOAGLAND DR, ARNON DI. 1938. The water-culture method for growing plants without soil. California Agricultural Experiment Station Circular 347, 1-39.

HUNER N, WILLIAMS J, KROL M, BOESE S, HURRY V, LAPOINTE L, REYNOLDS T. 1989. Photosynthesis, low temperature development and freezing tolerance. Current Topics in Plant Biochemistry and Physiology 8, 6-20.

KETELEER A, VANMECHELEN B, TOBBACK P. 1988. The evolution of dry matter, soluble protein and sugar content during frost hardening in some barley and wheat varieties differing in hardening capacity. Archives Internationales de Physiologie et de Biochimie 96, 17.

KNEEN E, BLISH MJ. 1941. Carbohydrate metabolism and winter hardiness of wheat. Journal of Agricultural Research 62, 1-26.

KROL M, GRIFFITH M, HUNER NPA. 1984. An appropriate physiological control for environmental temperature studies: comparative growth kinetics of winter rye. Canadian Journal of Botany 62, 1062-1068.

LẢNG V, HEINO P, PALVA ET. 1989. Low temperature acclimation and treatment with exogenous abscisic acid induce common polypeptides in Arabidopsis thaliana (L.) Heynh. Theoretical and Applied Genetics 77, 729-734.

LARSSON CH. 1985. Plasma membranes. In: Linskens HF, Jackson JF, eds. Vol.1. Cell Components, Modern Methods of Plant Analysis, New Series. Berlin: Springer-Verlag, 85104.

LARSSON S. 1983. An artificial freezing method useful for cold hardiness breeding in winter cereals. Sveriges Utsädesforeningens Tidskrift 93, 299-311.

LARSSON S, JOHANSSON LA, SVENNINGSSON M. 1992. Soluble sugars and membrane lipids in winter wheats (Triticum aestivum L) during cold acclimation. European Journal of Agronomy 1, 85-90.

LEVITT J. 1980. Responses of Plants to Environmental Stresses. 1. Chilling, Freezing and High Temperature Stresses. New York: Academic Press.

LIVINGSTON III DP, OLIEN CR, FREED RD. 1989. Sugar composition and freezing tolerance in barley crowns at varying carbohydrate levels. Crop Science 29, 1266-1270.

LYNCH DV, STEPONKUS PL. 1987. Plasma membrane lipid alterations associated with cold acclimation of winter rye seedlings (Secale cereale L. cv Puma). Plant Physiology 83, 761767.

MARENTES E, GRIFFITH M, MLYNARZ A, BRUSH RA. 1993. Proteins accumulate in the apoplasts of winter rye leaves during cold acclimation. Physiologia Plantarum 87, 499-507.

METCALFE LD, SCHMITZ AA. 1961. The rapid preparation of fatty acid esters for gas chromatographic analysis. Analytical Chemistry 33, 363-364.

PALTA JP. 1989. Plasma membrane ATPase as a key site of perturbation in response to freeze-thaw stress. Current Topics in Plant Biochemistry and Physiology 8, 41-68. 
PALTA JP, WEISS LS. 1993. Ice formation and freezing injury: An overview on the survival mechanisms and molecular aspects of injury and cold acclimation in herbaceous plants. In: $\mathrm{Li}$ PH, Christersson L, eds. Advances in Plant Cold Hardiness. Boca Raton, Florida, USA: CRC Press, 143-175.

PARKER J. 1959. Seasonal variations in sugars of conifers with some observations on cold resistance. Forest Science 5, 56-63.

PERRAS M, SARHAN F. 1989. Synthesis of freezing tolerance proteins in leaves, crown, and roots during cold acclimation of wheat. Plant Physiology 89, 577-585.

POLLOCK CJ. 1984. Sucrose accumulation and the initiation of fructan biosynthesis in Lolium temulentum L. New Phytologist 96, 527-534.

PONTIS HG. 1970. The role of sucrose and fructosylsucrose in fructosan metabolism. Physiologia Plantarum 28, 1089-1100.

PONTIS HG. 1989. Fructans and cold stress. Journal of Plant Physiology 134, 148-150.

PRESSMAN E, SCHAFFER AA, COMPTON D, ZAMSKI E. 1989. The effect of low temperature and drought on the carbohydrate content of asparagus. Journal of Plant Physiology 134, 209-213.

ROBERTSON AJ, CHURCHILL GC, GUSTA LV. 1993. The role of plant growth regulators on the freezing tolerance of winter annual cereals and cell suspension cultures. In: $\mathrm{Li} \mathrm{PH}$, Christersson L, eds. Advances in Plant Cold Hardiness. Boca Raton, Florida, USA: CRC Press, 253-271.

SAKAI A, LARCHER W. 1987. Frost Survival of Plants: Responses and Adaptation to Freezing Stress. Berlin, Heidelberg, New York: Springer Verlag.

SANTOIANI CS, TOGNETTI JA, PONTIS HG, SALERNO GL. 1993. Sucrose and fructan metabolism in wheat roots at chilling temperatures. Physiologia Plantarum 87, 84-88.

SIMINOVITCH D, RHEAUME B, POMEROY K, LEPAGE M. 1968. Phospholipid, protein, and nucleic acid increases in protoplasm and membrane structures associated with development of extreme freezing resistance in black locust tree cells. Cryobiology 5, 202-225.

SIMINOVITCH DJ, SINGH IA, DE LA ROCHE IA. 1978. Freezing behavior of free protoplasts of winter rye. Cryobiology 15, 205-213.

SINGH J, LAROCHE A. 1988. Freezing tolerance in plants: a biochemical overview. Biochemistry and Cell Biology 66, 650-657.

SMITH D. 1969. Removing and analyzing total nonstructural carbohydrates from plant tissue. Wisconsin Agricultural Station Research Report 41. 1-11.

STEPONKUS PL. 1978. Cold hardiness and freezing injury of agronomic crops. Advances in Agronomy 30, 51-98.

STEPONKUS PL, LYNCH DV, UEMURA M. 1990. The influence of cold acclimation on the lipid composition and cryobehaviour of the plasma membrane of isolated rye protoplasts. Philosophical Transactions of Royal Society of London. Biological Scienses 326, 571-583.

SUTINEN ML, RYBARCZYK SJ, PALTA JP. 1989. Seasonal changes in polar lipid fatty acid composition coincide with changes in freezing stress resistance in pine needles. Current Topics in Plant Biochemistry and Physiology 8, 286.

SUZUKI M, NASS HG. 1988. Fructan in winter wheat, triticale, and fall rye cultivars of varying cold hardiness. Canadian Journal of Botany 66, 1723-1728.

THOMASHOW MF. 1990. Molecular genetics of cold acclimation in higher plants. Advances in Genetics 28, 99-131.

TOGNETTI JA, SALERNO GL, CRESPI MD, PONTIS HG. 1990. Sucrose and fructan metabolism of different wheat cultivars at chilling temperatures. Physiologia Plantarum 78, 554-559.

UEMURA M, YOSHIDA S. 1984. Involvement of plasma membrane alterations in cold acclimation of winter rye seedlings (Secale cereale L. cv Puma). Plant Physiology 75, 818-826. 
VERESHCHAGIN AG, TRUNOVA TI, SHAYAKHMETOVA IS, TSYDENDAMBAEV VD. 1990. On the role of cell membrane lipids in cold hardening of winter wheat leaves and crowns. Plant Physiology and Biochemistry 28, 623-630.

VOLENEC JJ, BOYCE PJ, HENDERSHOT KL. 1991. Carbohydrate metabolism in taproots of Medicago sativa L. during winter adaptation and spring regrowth. Plant Physiology 96, 786-793.

WEINMANN H. 1947. Determination of total available carbohydrates in plants. Plant Physiology 22, 279-290.

YOSHIDA S, UEMURA M. 1984. Protein and lipid compositions of isolated plasma membranes from orchad grass (Dactylis glomerata L.) and changes during cold acclimation. Plant Physiology 75, 31-37.

ZÚNIGA GE, FERNANDEZ J, CRISTI R, ALBERDI M, CORCUERA LJ. 1990. Lipid changes in barley seedlings subjected to water and cold stress. Phytochemistry 29, 3087-3090. 


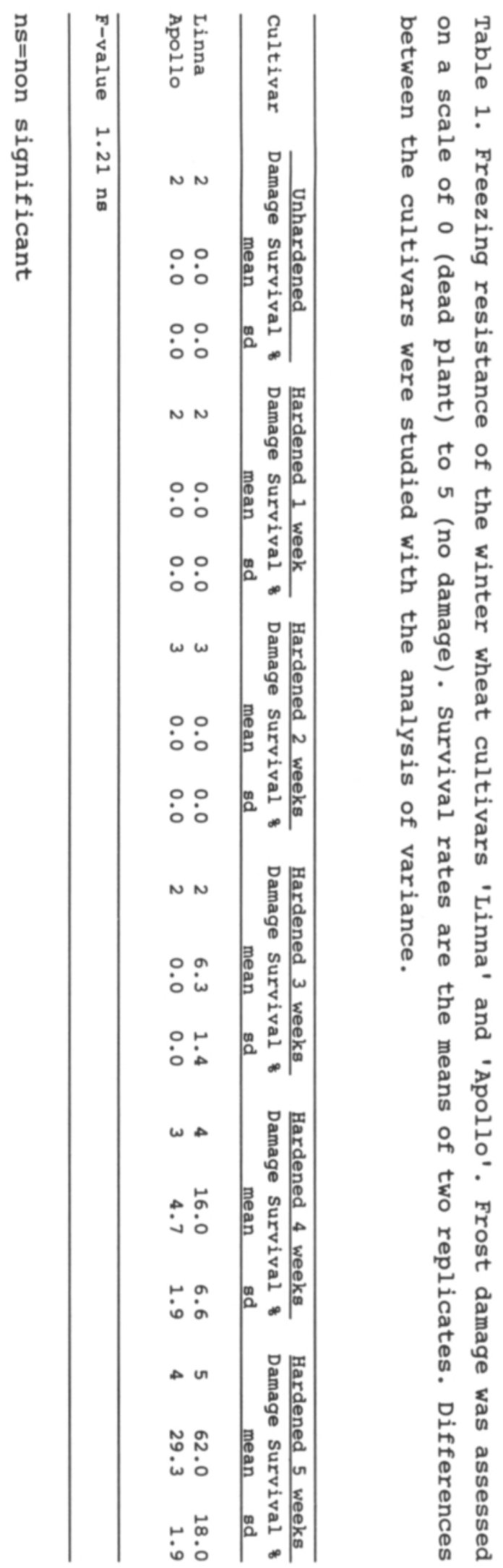


Table 2. Dry matter content in percent of fresh weight of leaves + crowns and roots of the cultivars 'Linna' and 'Apollo' before hardening (week 0 ) and after 1, 2, 3, 4 and 5 weeks of hardening.

\begin{tabular}{|c|c|c|c|c|c|c|c|c|c|c|c|c|}
\hline \multirow[t]{2}{*}{ Weeks } & \multicolumn{2}{|c|}{0} & \multicolumn{2}{|c|}{1} & \multicolumn{2}{|c|}{2} & \multicolumn{2}{|c|}{3} & \multicolumn{2}{|c|}{4} & \multicolumn{2}{|c|}{5} \\
\hline & mean & sd & mean & sd & mean & sd & mean & sd & mean & sd & mean & sd \\
\hline \multicolumn{13}{|l|}{ Leaves } \\
\hline Linna & 16.2 & 1.2 & 16.0 & 0.2 & 18.7 & 1.0 & 22.4 & 0.8 & 22.6 & 0.8 & 23.8 & 0.6 \\
\hline Apollo & 16.1 & 0.3 & 16.1 & 0.2 & 19.0 & 0.0 & 22.5 & 0.1 & 23.0 & 2.5 & 24.9 & 0.1 \\
\hline
\end{tabular}

\section{Roots}

$\begin{array}{lllllllllllll}\text { Linna } & 5.6 & 0.0 & 6.5 & 0.1 & 8.2 & 0.1 & 11.7 & 1.8 & 10.3 & 0.6 & 11.7 & 0.3\end{array}$

$\begin{array}{llllllllllllll}\text { Apollo } & 5.4 & 0.6 & 7.3 & 0.1 & 9.2 & 0.7 & 16.7 & 1.6 & 10.6 & 0.8 & 11.2 & 0.5\end{array}$



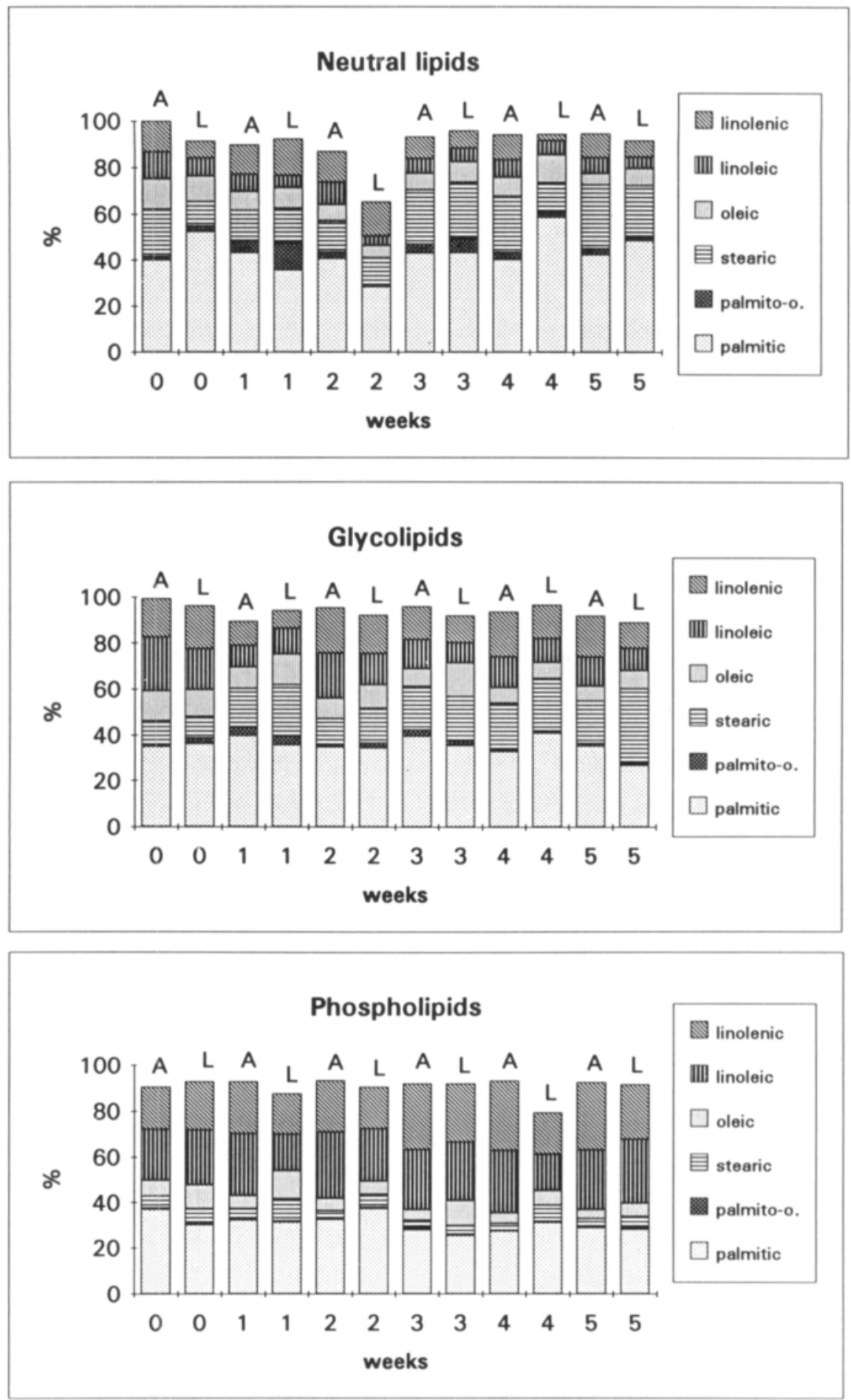

Figure 1. Changes in the relative fatty acids contents in plasma membrane lipid fractions (neutral lipids, glykolipids and phospholipids) in the cultivars 'Apollo' (A) and 'Linna' (L) in non-hardened plants and after 1-5 weeks of cold acclimation. Values are percentages of the total fatty acids determined, all of which are not included in the Figure (deviations from 100\%).

Palmito-o. = palmito-oleic acid. 


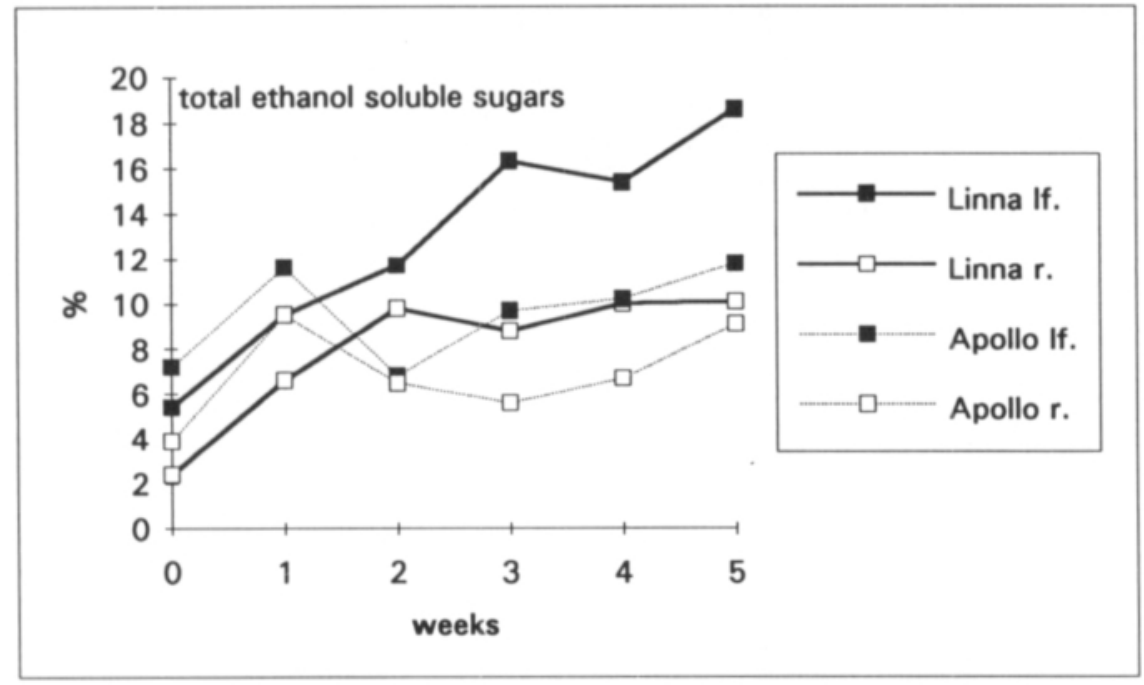

Figure 2. Total contents of ethanol-soluble sugars (\% of dry matter) in the green parts (lf.) and in the roots (r.) of the cultivars 'Linna' and 'Apollo' studied in non-hardened and 1-5 weeks hardened plants.

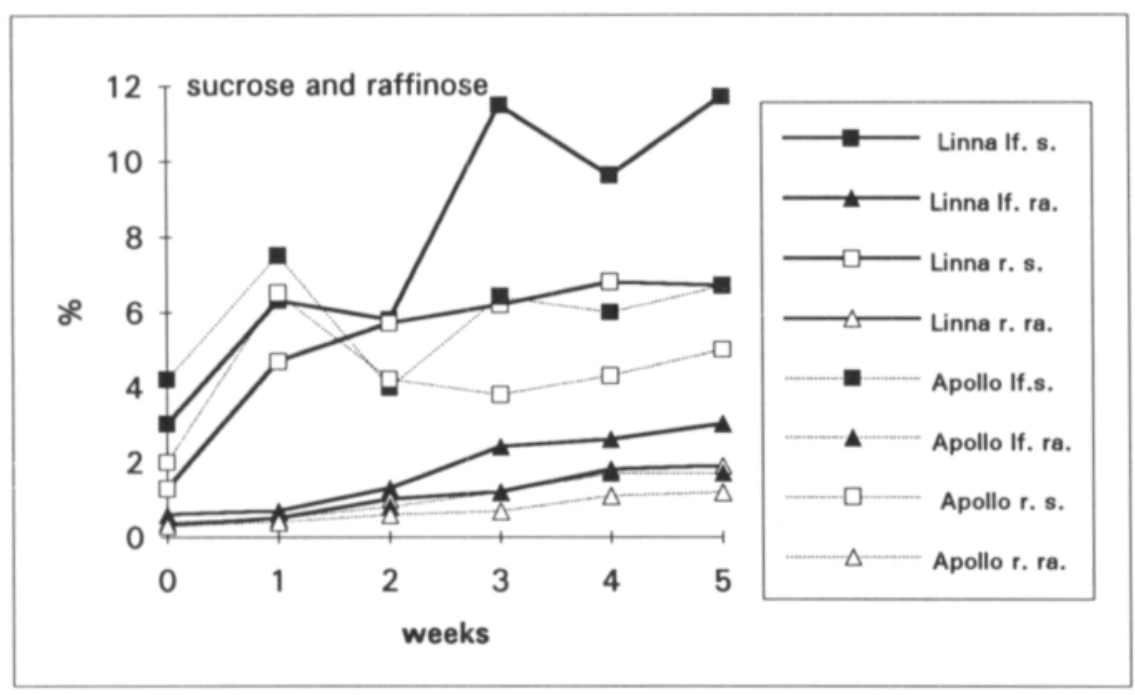

Figure 3. Sucrose (s.) and raffinose (ra.) contents (\% of dry matter) in the green parts (If.) and in the roots ( $r$.) of the cultivars 'Linna' and 'Apollo' studied in non-hardened and 1-5 weeks hardened plants. 

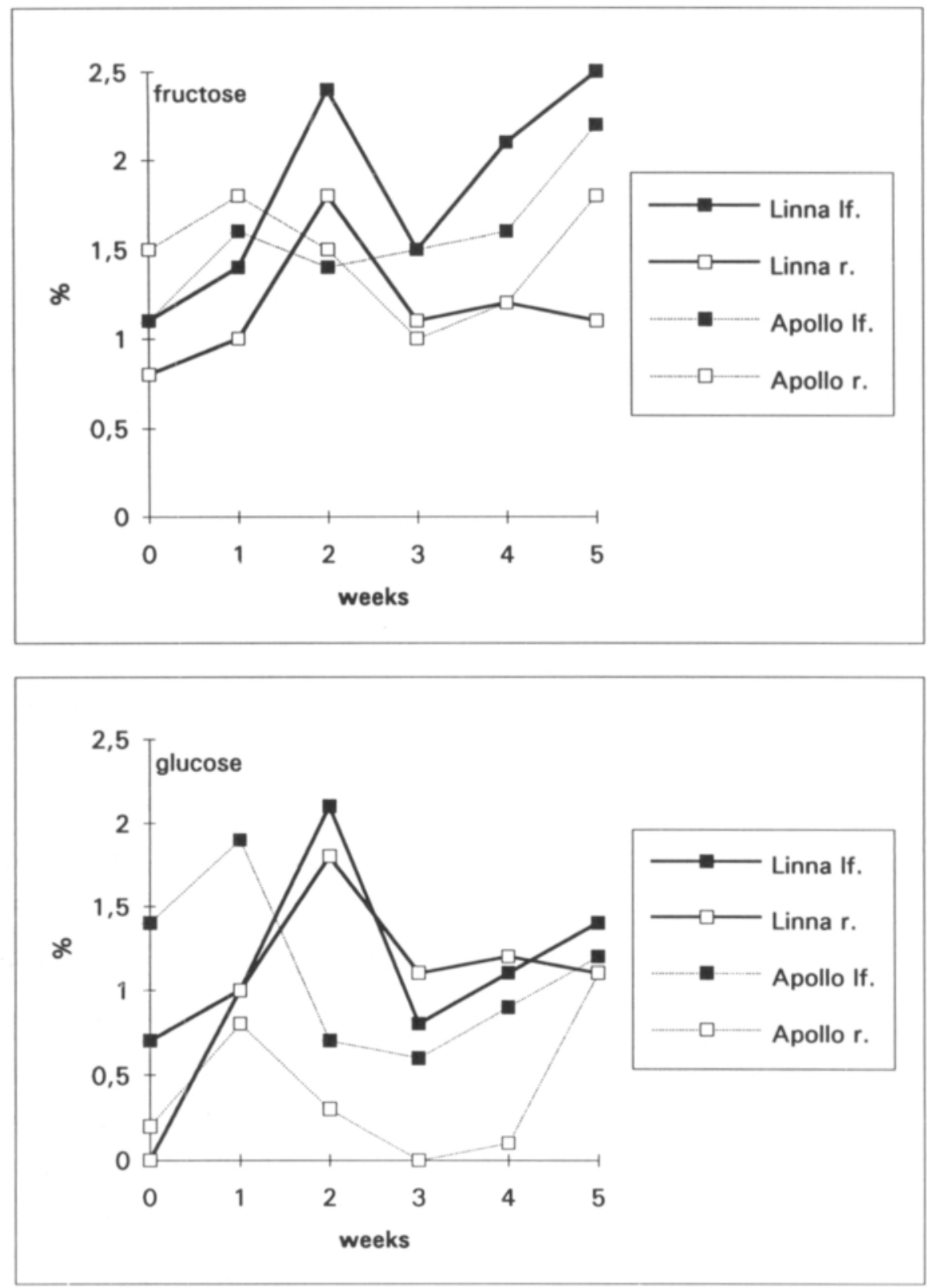

Figure 4. Fructose and glucose contents ( $\%$ of dry matter) in the green parts (If.) and the roots (r.) of the cultivars 'Linna' and 'Apollo' studied in non-hardened and 1-5 weeks hardened plants. 


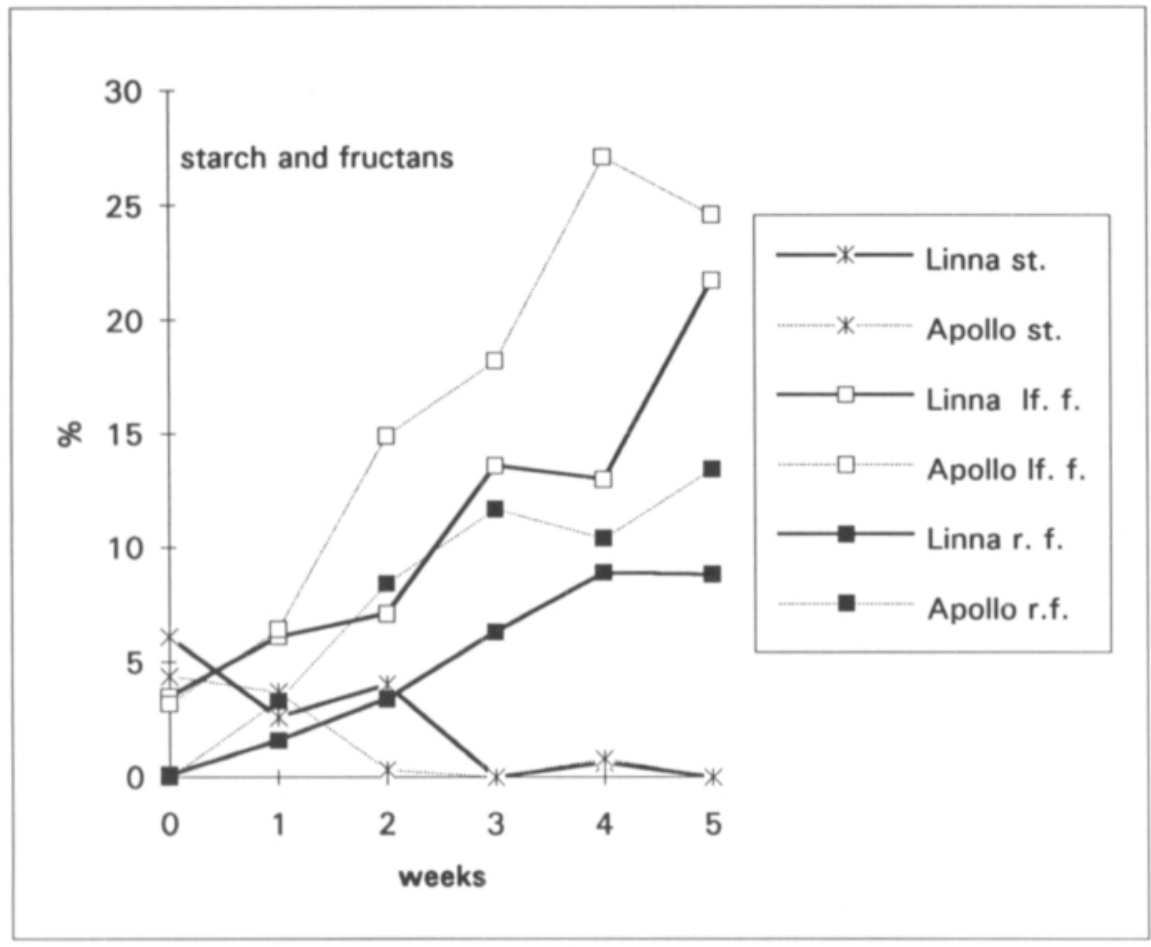

Figure 5. Contents of starch (st.) and fructans (f.) (\% of dry matter) in the green parts (If.) and the roots (r.) (only fructans) of the cultivars 'Linna' and 'Apollo' studied in non-hardened and 1-5 weeks hardened plants. 



\title{
Hömmö, L. Hannukkala, A. and Pulli, S.
}

\author{
Agricultural Research Centre \\ Institute of Plant Breeding \\ SF-31600 Jokioinen, Finland
}

\section{Screening for resistance of winter wheat and rye varieties to finnish snow mould (Microdochium nivale) isolates}

\section{ABSTRACT}

The snow mould resistance of eight winter wheat and eight winter rye varieties was tested both in field and laboratory experiments. The Finnish winter wheat (Linna, Aura, Vakka) and rye (Jussi, Anna, Voima) varieties that have been selected under Finnish winter conditions, in general were the most resistant ones against the native snow mould strains on the test fields and against the isolate used in the laboratory tests. Cellulase and pectinase activity and aggressiveness of $M$. nivale isolates collected from eight locations in southern an central parts of Finland were studied. In general both cellulolytic and pectolytic enzymes produced by different snow mould strains were quite ineffective according to the viscometric analysis. However, isolates differed in their pectolytic enzyme activity. The isolates with high pectinase activity seemed to have high infection capacity. Thus it seems possible to improve the effectiveness of snow mould testing of cereal varieties by selecting the most aggressive snow mould isolates for the tests or by using proper mixtures of them.

\section{INTRODUCTION}

The fact that Finland is located between continental and maritime climatic zones brings about extremely variable weather conditions during winter time. Overwintering plants must have resistance to both abiotic (frost, ice-or/and water cover, heaving) and biotic (e.g. snow moulds) factors. Microdochium nivale (Fr.) Samu \& Hall, the most important causal agent of snow mould in Finland, is present throughout winter cereal (wheat and rye) growing area. In eastern Finland, rather severe damages are also caused by Typhula species ( $T$. ishicariensis Imai and $T$. incarnata Lash. ex. Fr.) and less frequently by Sclerotinia borealis Bub. \& Vleug.

Proper laboratory tests for screening breeding material under controlled condi- 
tions must be developed since field trials tend to characterise general winter survival abilities of varieties rather than their specific resistance to any particular stress factor, like snow mould,

Snow mould resistance of overwintering cereals and grasses has been under intensive research in all Scandinavian countries. Several different laboratory tests has been developed (Arsvoll 1977, Arsvoll and Larsen 1977, Blomqvist and Jamalainen 1968, Elovson and Nilsson 1992, Jamalainen 1974, Jönsson and Nilsson 1986 and 1992, Meyer 1986, Tronsmo 1984, 1985, 1986 and 1992, Vestman 1986 ). The aims of this study were to test differences of some winter wheat and winter rye varieties in their snow mould resistance and to investigate pathogenicity and enzyme activities of certain $M$. nivale isolates.

\section{MATERIALS AND METHODS}

Overwintering capacity of eight winter wheat and eight winter rye varieties and their resistance against Microdochium nivale was compared in field and laboratory experiments. Winter wheat cultivars "Linna", "Aura", "Vakka", "Solid", "Hildur", "Folke", "Kosack" and "Norstar" and winter rye cultivars "Jussi", "Anna", "Voima", "Kungs II", "Petkus II", "Danko", "Epos" and "Talovskaja 12" were used in tests.

Field tests

The field trials were carried out at five locations: Jokioinen $\left(60^{\circ} 49^{\prime} \mathrm{N}, 23^{\circ} 30^{\prime} \mathrm{E} /\right.$, Anjalankoski $\left(60^{\circ} 43^{\prime} \mathrm{N}, 26^{\circ} 48^{\prime} \mathrm{E}\right.$, Pňlkn̆ne $\left(61^{\circ} 20^{\prime} \mathrm{N}, 24^{\circ} 13^{\prime} \mathrm{E}\right)$, Laukaa $\left(62^{\circ} 20^{\prime} \mathrm{N}\right.$, $26^{\circ} 10^{\prime}$ EI and Sotkamo $\left(64^{\circ} 06^{\prime} \mathrm{N}, 28^{\circ} 20^{\prime} \mathrm{E}\right)$ in years 1990 and 1991 . Each variety was sown in a $1 \mathrm{~m}$ long row. Rows were completely randomized and four replicates of each cultivar were included.

The number of germinated plants was counted in autumn and the number of surviving plants was counted in spring soon after the snow had melt to estimate the survival-\%. Simultaneously the damage caused by snow mould was rated on scale 0 (totally undamaged plants to 6 (totally killed plant).

Snow mould isolates were obtained from infected plant tissue collected from eight locations: Jokioinen, Anjalankoski, Pňlkňne, Laukaa, Salo $\left(60^{\circ} 15^{\prime} \mathrm{N}\right.$, $\left.23^{\circ} 1 \mathrm{O}^{\prime} \mathrm{E}\right)$, Hauho $\left(61^{\circ} 12^{\prime} \mathrm{N}, 2^{\circ} 34^{\prime} \mathrm{E}\right)$, Mouhijarvi $\left(61^{\circ} 31^{\prime} \mathrm{N}, 23^{\circ} \mathrm{E}\right)$ and Ylistaro $\left(62^{\circ} 56^{\prime} \mathrm{N}, 22^{\circ} 30^{\prime} \mathrm{E}\right)$ in spring 1991 . They were isolated as pure cultures and stored deep frozen at $-80^{\circ} \mathrm{C}$ for further use.

\section{Laboratory tests}

Plants for the testing of resistance were grown either in plastic boxes filled with peat-soil-mixture or in pots containing nutrition solution (Hoagland \& Arnon 1938. Plants were kept in greenhouse until two-leaves stage, and hardened for four weeks in $2^{\circ} \mathrm{C}$ before inoculation with $M$. nivale.

Inoculum for the tests was prepared by growing $\mathrm{M}$. nivale-isolates on Bacto Potato Dextrose Agar (DIFCO 0013-01-4)(PDA) for two weeks at $18^{\circ} \mathrm{C}$ temperature. 
Spores were then washed from the surface of agar-plate into distilled water. The number of harvested propagules was counted by Fuchs-Rosenthal cell counter and the concentration of suspension was then adjusted to approximately 1 milj. propagules per $\mathrm{ml}$.

Inoculum was sprayed on test plants with a hand sprayer and they were covered with moistened cellulose wadding and plastic sheets as described by Blomqvist and Jamalainen (1968) and Arsvoll (1977). Plants were incubated for 6-7 weeks in $2^{\circ} \mathrm{C}$ and rated for the damage on scale 0 (undamaged) to 5 (totally dead). The final survival-\% of plants was calculated from the number of alive plants after ten days recovery period in greenhouse at $20^{\circ} \mathrm{C}$ temperature.

To test the pathogenicity of the collected snow mould isolates test plants (winter rye "Anna") were grown in nutrition solution as described above. 20 plants were transferred onto moistened germination paper sheet and inoculated as described above. Each treatment was replicated four times. The sheets were then wrapped up and incubated in plastic bags at $10^{\circ} \mathrm{C}$. After two weeks each plant was rated for the degree of damage.

The cellulase and pectinase activities of $M$. nivale were measured by viscometric assay (Yoshida et al. 1989 and Stack et al. 1980) using carboxymethyl cellulose $(\mathrm{CMC})$ and pectin as substrates. To obtain the enzyme preparate 10 discs $(5 \mathrm{~mm}$ in diameter) of snow mould mycelia growing on PDA were transferred into $200 \mathrm{ml}$ of Czapek-Dox medium $\left(0.1 \% \mathrm{~K}_{2} \mathrm{HPO}_{4}, 0,05 \% \mathrm{KCL}, 0.2 \% \mathrm{NaNO}_{3}, 0.05 \% \mathrm{MgSO}_{4}\right.$ and $0.002 \% \mathrm{FeSO}_{4}, \mathrm{pH} 6.0$ ) without agar. Autoclaved wheat leaf pieces were added as a carbon source. After incubation with shaking 3 days at $5^{\circ} \mathrm{C}$ and one week at $20^{\circ} \mathrm{C}$ the mycelia and leaf pieces were removed from the culture by filtration (Macherey-Nagel No.615 filter paper). The resulting culture filtrate was dialyzed overnight at $2^{\circ} \mathrm{C}$ against several liters of distilled water and used as the crude enzyme preparate in viscometric analysis.

The substrates consisted of $2.5 \mathrm{mg} \mathrm{CMC}$ in $50 \mu$ mol sodium acetate buffer $(\mathrm{pH}$ 5.6) for cellulolytic and $1.5 \%$ pectin (from apple Sigma P-21571 in $50 \mathrm{mmol}$ Tris$\mathrm{HCl}$ (pH 8.5) containing $0.1 \mathrm{mmol} \mathrm{CaCl} 2$ for pecteolytic enzymes. For the viscometry assay, $417 \mu \mathrm{I}$ of substrate and $83 \mu \mathrm{I}$ enzyme solution were reacted in the Brookfield Digital Viscometer model DV-II, with incubation at $30^{\circ} \mathrm{C}$. Autoclaved enzymes were used as controls. The reduction in viscosity of the substrate-enzyme mixture was determined after 30 minutes and was considered as the enzyme activity of the snow mould isolate.

\section{RESULTS AND DISCUSSION}

Both the field trials and the laboratory tests show that there are clear differences in the snow mould resistance of varieties (Figs 1 . and 2.). The Finnish winter wheat ("Linna", “Aura", "Vakka") and rye ("Jussi", "Anna", "Voima" varieties that have been selected in Finnish winter conditions, in general were the most resistant ones against the native snow mould strains on the test fields and against the isolate used in the laboratory tests. 
winter wheat

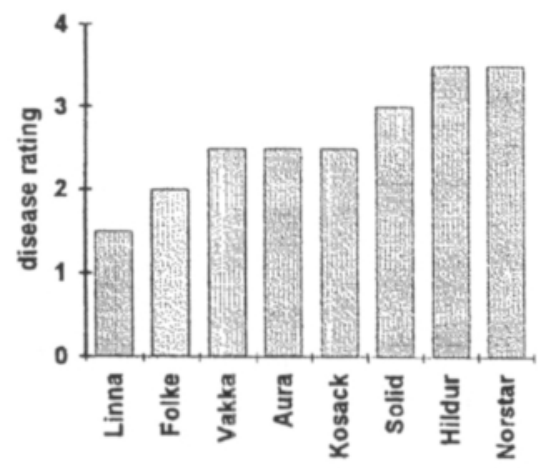

winter rye

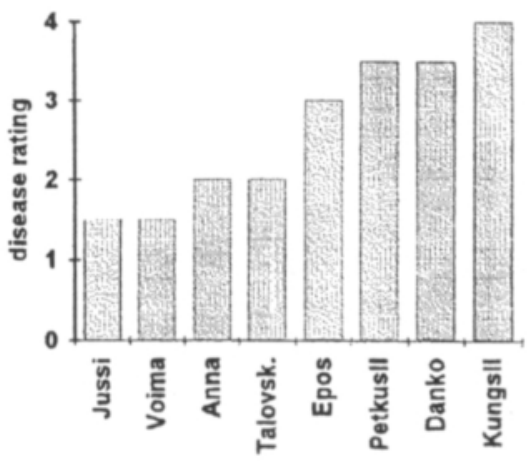

Figure 1. Field resistance of eight winter wheat and winter rye cultivars to Microdochium nivale measured as disease rating on scale 0 (healthy plant) to 6 (totally death plant). Figures are means of years 1991-92 at five locations.

winter wheat

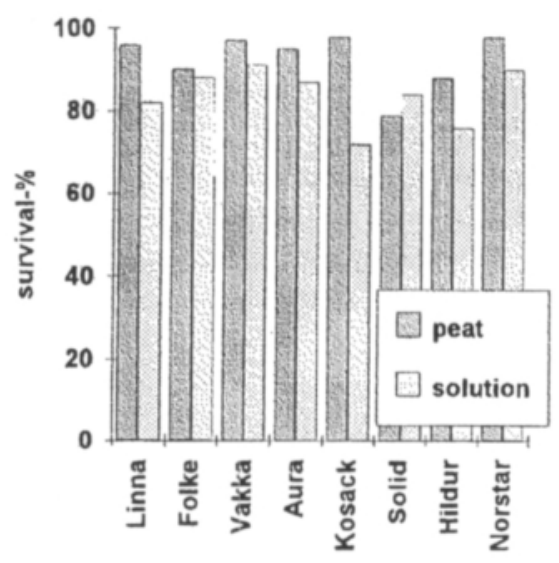

winter rye

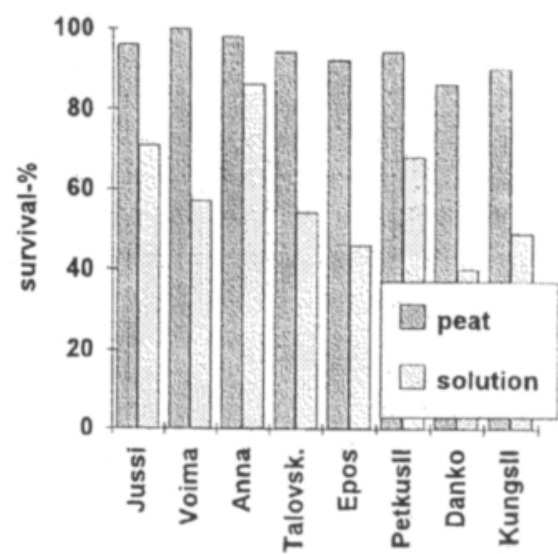

Figure 2. Laboratory testing of resistance of eight winter wheat and winter rye cultivars to Microdochium nivale. Plants were grown either in peat-soil mixture or in nutrition solution and the figures are survival-\%:s of plants after snow mould infection. 
Snow mould isolates differed clearly from each other in their infection ability (Fig. 3.). After two weeks incubation period some isolates killed almost all the wheat plants, while some others caused only minor damage on plants.

a

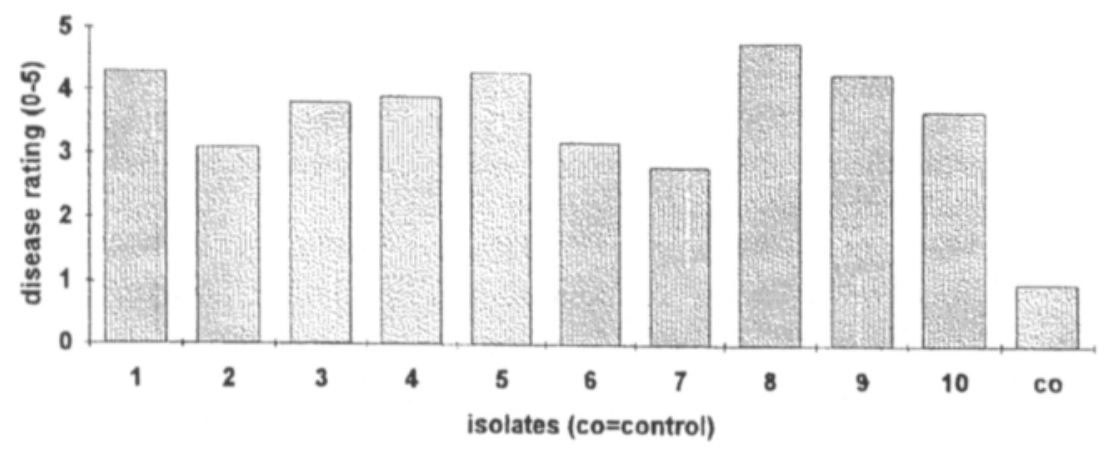

b cellulolytic $\square$ pectolytic

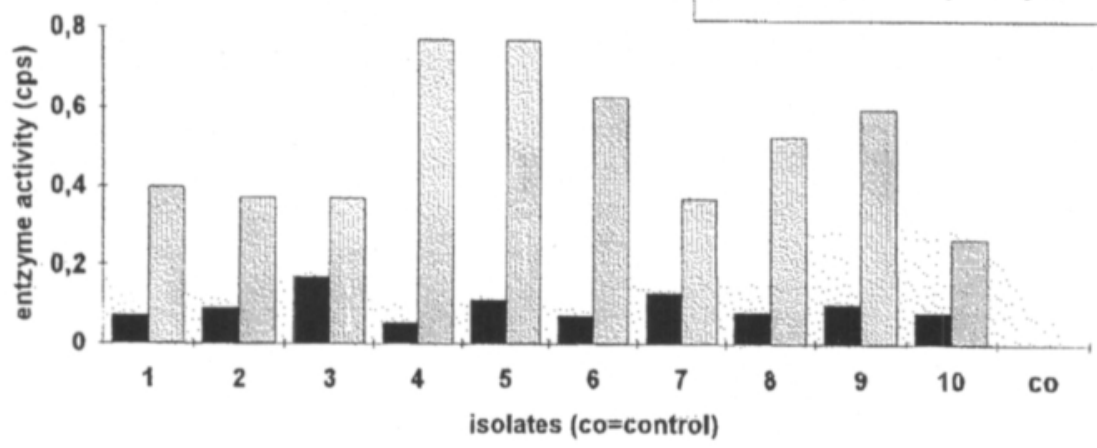

Figure 3. (a.) The pathogenicity of 10 Microdochium nivale isolates measured as disease rating on scale 0 (healthy plant) to 5 (totally death plant). (b.) The enzyme activity of isolates was measured as the decrease of viscosity (in centipoises cps) of substrate + enzyme reaction mixture in 30 minutes.

As the whole both the cellulolytic and pectolytic enzymes isolated from the snow mould strains turned out to be quite ineffective in the viscometric analysis. There was, however, clear differences especially in the activities of pectolytic enzymes in different strains. The high pectinase activity seems to correlate positively with the infection ability of the snow mould isolate, and probably the most pathogenic isolates could be selected on the basis of their pectinase activity. The tested 
isolates were rather similar in their cellulase activity (Fig. 3.).

\section{REFERENCES}

1. Arsvoll, K. 1977. Effects of hardening, plant age, and development in Phleum pratense and Festuca pratensis on resistance to snow mould fungi. -MeId. Norg.- LandbrHŔgsk. 56(28): 14pp.

2. Arsvoll, K., and Larsen, A. 1977. Effects of nitrogen, phosphorus, and potassium on resistance to snow mould fungi and on freezing tolerance in Phleum pratense.- Meld. Nor. Landbr. Högsk. 57(29): 14pp.

3. Blomqvist, H.H., and Jamalainen, E.A. 1968. Preliminary tests on winter cereai varieties of resistance to low temperature parasitic fungi $\mathrm{n}$ controlled conditions.- Maataloust. aikakausk. 40: 88-95.

4. Elovson, R., and Nilsson, C. 1992. Test for tolerance to grey snow mould (Typhula spp.) in winter barley. Norwegian J. Agric. Sci. Supplement. 7: 51-54.

5. Hoagland, D.R., and Arnon, I. 1938. The water-culture method for growing plants without soil. Calif. Agr. Exp. Sta. Cir. 347: 39pp.

6. Jamalainen, E.A. 1974. Resistance in winter cereals and grasses to low-temperature parasitic fungi. Ann Rev. Phytopath. 12: 281-302.

7. Jönsson, H.A., and Nilssn, C. 1986. Plant breeding for resistance to snow moulds in grasses. NJF Seminar Nr. 84, Lantbruksvňxternas överwintring 4-6 juni 1986, Jokioinen, Finland, pp.: 145-148.

8. Jönsson, H.A., and Nilsson, C. 1992. Grass variety reaction to selection for resistance to Typhula ishikariensis. Norwegian J. Agric. Sci. Supplement 7: 25-34.

9. Meyer, J. 1986. Testing snow mould resistance in winter cereals. NJF Seminar Nr. 84, Lantbruksvaxternas verwintring 4-6 juni 1986, Jokioinen, Finland, pp. 139-144.

10. Stack, J.P., Mount, M.S., Berman, P.M., and Hubbard, J.P. 1980. Pectic enzyme complex from Erwinia carotovora. a model for degradation and assimilation of host pectic fractions. Phytopathology. 70(4): 267-272.

11. Tronsmo, A.M. 1984. Predisposing effects of low temperature on resistance to winter stress factors in grasses. Acta Agric. Scand. 34: 210-220.

12. Tronsmo, A.M. 1985. Effects of dehardening on resistance to freezing and to infection by Typhula ishikariensis in Phleum pratense. Acta Agric. Scand. 35: 113-116.

13. Tronsmo, A.M. 1986. Winter injury in agricultural crops caused by low temperature fungi. NJF Seminar Nr. 84, Lantbruksvaxternas vervintring 4-6 juni 1986, Jokioinen, Finland pp: 81-97.

14. Tronsmo, A.M. 1992. Resistance to snow mould fungi in breeding material of grasses. Norwegian J. Agric. Sci. Supplement. 7: 35-8.

15. Vestman, G. 1986. Urval för resistens motutvintringssvamppar i timotej. NJF Seminar Nr. 84, Lantbruksvňxternas övervintring 4-6 juni 1986, Jokioinen, Finland pp: 111-115.

16. Yoshida, N., Fukushima, T., Saito, H., Shimosaka, M., and Okazaki, M. 1989. 
Cellulose and xylan degrading enzymes of the plant pathogenic fungus, Fusarium oxysporum SUF850. Agric. Bol. Chem. 537: 1829-183. 
ERRATA

Hod. Rośl. Aklim. Nasien. 37 (3)

\begin{tabular}{|c|c|c|c|}
\hline Page & Row number & It is: & It should be: \\
\hline 4 & 16 from top & grateffully & gratefully \\
\hline 17 & 12 from top & avenacceum & avenaceum \\
\hline 49 & 5 from bottom & NijkamP & Nijkamp \\
\hline 51 & 8 from top & herotrichoides & herpotrichoides \\
\hline 58 & 22 from bottom & Anfňlligkeit & Anfälligkeit \\
\hline 58 & 7 from bottom & Pathogenitňt & Pathogenität \\
\hline 59 & 11 from bottom & Thhrenkrankheits. .. & Ährenkrankheits. . . \\
\hline 75 & 8 from top & gramnearum & graminearum \\
\hline 75 & 9 from bottom & Fusarum & Fusarium \\
\hline 88 & 4 from bottom & $\cap$ & \pm \\
\hline 89 & 14 from bottom & $\cap$ & \pm \\
\hline 97 & 20 from bottom & $18 \mathrm{C}$ & $18^{\circ} \mathrm{C}$ \\
\hline 98 & Table 1 & $\cap$ & \pm \\
\hline 99 & Table 2 & $\cap$ & \pm \\
\hline 108 & Table 1 & spikkelets & spikelets \\
\hline$\overline{1} 33$ & 5 from top & finnish & Finnish \\
\hline 134 & 21 from bottom & $\mathrm{E} /$ & E), \\
\hline 134 & 20 from bottom & Pňlkňne & Pälkäne \\
\hline 134 & 19 from bottom & EI & E) \\
\hline 134 & 11 from bottom & Pňlkňne & Pälkäne \\
\hline 138 & 5 from top & LandbrHŔgsk & Landbr. Högsk. \\
\hline 138 & 19 from top & Landbruksvňxternas & Landbruksväxternas \\
\hline 138 & 8 from bottom & vervintring & övervintring \\
\hline 138 & 3 from bottom & Landbruksvňxternas & Landbruksväxternas \\
\hline 141 & 8 from top & gentypes & genotypes \\
\hline 144 & 5 from bottom & Fundulsa & Fundulea \\
\hline 145 & 7 from bottom & hih & high \\
\hline 148 & 11 from bottom & rnstochiensis & rostochiensis \\
\hline 149 & 5 from top & rnstochiensis & rostochiensis \\
\hline 162 & 15 from top & susuceptibility & suceptibility \\
\hline 163 & Table 2 & nivale & nivale \\
\hline 170 & 12 from bottom & tsterreich & Österreich \\
\hline 175 & 7 from bottom & Thhrenkrank ... & Ährenkrank ... \\
\hline 186 & 13 from bottom & ůvfolyam & Évfolyam \\
\hline 186 & 12 from bottom & SZśM & SZÁM \\
\hline 190 & Tab. 1 , row 12 , col. 2 & + & ++ \\
\hline
\end{tabular}



RESISTANCE Hömmö L.M. Agricultural Research Centre of Finland Institute of Plant Breeding SF-31600 Jokioinen, Finland 


\section{SUMMARY}

In this study the snow mould (Microdochium nivale) resistance of 13 winter rye cultivars was studied in field trials and in three different laboratory tests: snow mould chamber tests, enzymatic assay tests and leaf segment tests. On the basis of the results, it is suggested that both the field trials and the snow mould chamber tests describe more the general winterhardiness of plants and the snow mould resistance, that is involved in the survival of the crown tissue of plants during prolonged incubation under the snow cover. The results from the enzymatic assay and the leaf segment tests indicate that there are also other, more specialized snow mould resistance mechanisms in the plant that act also on the single leaf level. At least some of these resistance reactions seem to be induced by the lytic enzymes secreted by $M$. nivale. 


\section{INTRODUCTION}

In Finland, the weather conditions during winter frequently favour the development of snow mould fungi. The pink snow mould Microdochium nivale (Fr.) Samuel \& Hall, (syn. Fusarium nivale (Fr.) Ces), the most important causal agent of snow mould in winter wheat and rye in Finland (Jamalainen, 1974), especially damages winter cereals (wheat and rye) throughout their cultivation area.

In eastern Finland, rather severe damage is also caused by Typhula ishikariensis Imai, $T$. incarnata Lash. ex. Fr. and less frequently by Myriosclerotinia borealis Bub. \& Vleug.

As field trials are often inefficient in screening the snow mould resistance of plants, many laboratory tests for the screening of breeding materials under controlled conditions have been developed. Most of the available laboratory tests are based on the same 'snow mould chamber method'. By this method, naturally or artificially hardened plants are inoculated with fungus propagules, incubated for several weeks in cool conditions and finally, after a recovery period, the amount of damage to the plants is estimated. However, this method is time-consuming and costly, although Nakajima \& Abe (1990) and Takenaka \& Yoshino (1989) were able to shorten the method by the use of high temperatures $\left(+18^{\circ} \mathrm{C}\right)$ during the incubation period.

In spite of these drawbaks, only a very few alternative test methods have been described in the literature.

Since $M$. nivale is either unable to produce typical Fusarium toxins or the toxin level is very low (Chelkowski et al., 1991; Logrieco et al., 1991), the in vitro selection methods developed for Fusarium species (e.g. Ahmed et al., 1991) are not suitable for screening the M. nivale resistance of plants (Pauk et al., 1990).

Many studies have dealt with the enzyme composition of pathogens and the factors promoting enzyme production and function in host plants (Chang et al., 1992; Stack et al., 1980; Yoshida et al., 1989). However, the use of pathogen enzymes in screening for the resistance of host plants has been very limited. McBeath (1991) found a close correlation between the level of chlorosis present in winter wheat leaf segments treated with extracellular enzymes secreted by Myriosclerotinia borealis and the snow mould resistance of the corresponding winter wheat cultivars.

Detached leaf segments, instead of whole plants, are frequently employed in disease tests for some pathogens, for example Septoria nodorum (Baker \& Smith, 1978; Benedikz et al., 1981), Erysiphe graminis (Hilbers et al., 1992) and Pyrenophora teres (Jalli 1992), but snow mould tests have been almost completely confined to the use of whole, growing plants. 
The aim of this study was to find out if $M$. nivale resistance of rye cultivars could be tested with methods based on the enzymes extracted by $M$. nivale or on the use of detached leaf segments instead of whole plants. The snow mould resistance of cultivars was tested also in field and with traditional and somewhat modified snow mould chamber tests. The correlations between different kinds of tests and also the correlation between the frost and snow mould resistance of cultivars was studied.

The possibility of employing various snow mould tests to find out different kinds of snow mould resistance mechanisms in plants is also discussed in this paper.

\section{MATERIALS AND METHODS}

The snow mould resistance of 13 winter rye cultivars, Jussi, Voima, Anna, Kungs II, Danko, Epos, Petkus II, Dominator, Talovskaja 12, Norderåstetra, Vågonäs höstråg, Musketeer and Prima, was tested in both field trials and laboratory experiments.

\section{Field trials}

The field trials were part of the Inter-Nordic 'Winterhardiness' Project, and were carried out

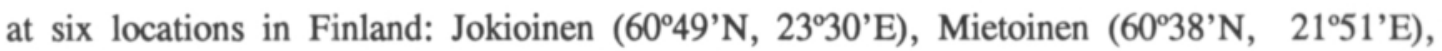

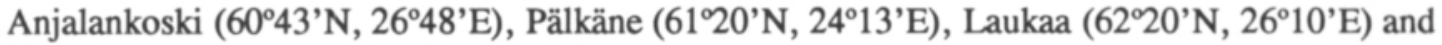
Sotkamo (6406'N, 28²0'E) during 1990-1991 and 1991-1992. A randomized block design with four replicates was employed, and the experimental unit was a $1 \mathrm{~m}$ long row. The plots were not inoculated.

In the spring, as soon as the snow had melted, the snow mould ( $M$. nivale) damage was rated on a scale of 0 (totally undamaged plant) to 10 (dead plant).

Analyses of variance were used to identify the trials in which the differences in the snow mould damage among cultivars were statistically significant. From these trials, overall means of snow mould damage on cultivars were calculated.

\section{Laboratory tests}

A mixture (1:1:1) of three isolates of $M$. nivale (FN61, FN62 and 93/06) was used in the laboratory tests. The isolates were obtained from infected plant tissue specimens collected from Jokioinen (FN61, FN62) and Pälkäne (93/06). The samples were isolated as pure cultures and then stored at $-80^{\circ} \mathrm{C}$. The disease reaction of the winter rye cultivars was studied by three different methods as follows: 


\section{A) Snow mould chamber test}

Eight of the rye cultivars (Jussi, Voima, Anna, Kungs II, Danko, Epos, Petkus II, Talovskaja 12) were used in snow mould chamber tests. The experimental plants were grown in plastic boxes filled with a peat-soil mixture. In a modification of this test, the plants were grown in beakers containing a nutrient solution (Hoagland \& Arnon, 1938). There were four boxes representing four replicates, and one box as a control without the snow mould (M. nivale) inoculation. The cultivars (15 seeds) were sown in rows in the boxes and the order of the rows was randomized. To avoid a border effect, the first and the last row were sown with cv Anna, and left unanalyzed. In the modified test, with plants grown in beakers ( 50 seeds/beaker), four beakers per cultivar were used as replicates, and one as a control without inoculation.

The plants were kept in a greenhouse $\left(+20^{\circ} \mathrm{C} /+10^{\circ} \mathrm{C}, 18 / 6 \mathrm{~h}\right.$ photo- period and $\left.12000 \mathrm{lux}\right)$ until the two leaf stage and hardened for 4 weeks at $+2^{\circ} \mathrm{C}(16 / 8 \mathrm{~h}$ photoperiod $4000 \mathrm{lux})$ before inoculation with $M$. nivale. The inoculum was prepared as described by Hömmö et al. (1993) and it was sprayed onto the test plants using a hand sprayer. Test plants were covered with moistened cellulose wadding and plastic sheeting as described by Blomqvist \& Jamalainen (1968) and Ársvoll (1977). After an incubation period of 7 weeks (nutrient solution) or 9 weeks (peat-soil) at $+2^{\circ} \mathrm{C}$, the plants were rated on a scale of 0 (undamaged) to 5 (extensive damage). The final survival rate was calculated from the number of plants that survived after a $10 \mathrm{~d}$ recovery period in the greenhouse.

\section{B) Enzymatic assay}

In order to obtain the enzyme preparation used in the test, $8 \mathrm{ml}$ of $M$. nivale suspension ( $1 \mathrm{x}$ $10^{6}$ spores $\left.\mathrm{ml}^{-1}\right)$ was added to $200 \mathrm{ml}$ of Czapek-Dox medium $\left(0.1 \% \mathrm{~K}_{2} \mathrm{HPO}_{4}, 0.05 \% \mathrm{KCL}\right.$, $0.2 \% \mathrm{NaNO}_{3}, 0.05 \% \mathrm{MgSO}_{4}$ and $0.002 \% \mathrm{FeSO}_{4}, \mathrm{pH} 5.0$ ) without agar. Then $10 \mathrm{~g}$ of autoclaved rye leaf segments were added as a carbon source to each Ehrlenmyer flask. To further stimulate the production of cellulolytic and pectolytic enzymes, half of the cultures were supplemented with $0.1 \%$ carboxymethyl cellulose (CMC Sigma C-5678) and the other half with $0.1 \%$ pectin (from apple, Sigma P-2157). After incubation in a shake culture for 3 days at $+6^{\circ} \mathrm{C}$ in darkness and for one week at $+20^{\circ} \mathrm{C}$ in the greenhouse, the mycelia and leaf segments were removed from the culture by filtration (Machery-Nagel No.615 filter paper) and the filtrate was centrifuged at $10000 \mathrm{~g}$ and $+5^{\circ} \mathrm{C}$ for $30 \mathrm{~min}$. The enzyme activity of the resulting culture filtrates was assessed by viscometric assay (Yoshida et al., 1989; Stack et al., 1980) employing CMC and pectin as substrates, using a Brookfield Digital Viscometer DV-II. 
Three kinds of enzyme solutions were used in the test. One-third of the plant material was tested with an enzyme preparation originating from the CMC-supplemented culture filtrate, onethird with the pectin-supplemented culture filtrate and the last third with a mixture (1:1) of these two. An autoclaved enzyme mixture was used as the control. Leaf segments were cut from the first leaf of about 30-40 plants per cultivar, mixed, and $0.2 \mathrm{~g}$ of segments were weighed into $15 \mathrm{ml}$ of the enzyme preparation. Tween-20 and Streptomycin-C were then added to each of the test tubes. There were two replications of the treatments with either cellulolytic or pectolytic enzymes, and three replications of the treatment with both. The leaf segments were incubated in the enzyme solution on a shaker for one week at $+6^{\circ} \mathrm{C}$ in darkness. After this the leaf segments were filtered from the solution, dried on filter paper and frozen until analysis.

The effusates were centrifuged $\left(4000 \mathrm{~g},+5^{\circ} \mathrm{C}, 15 \mathrm{~min}\right)$ and the chlorophyll content of the supernatants was determined spectrophotometrically using a Varian Techtron 634 Spectrophotometer at 645 and $663 \mathrm{~nm}$. The total chlorophyll content was calculated using an equation developed by Hipkins \& Baker (1987). The frozen leaf segments were ground in liquid nitrogen and the total chlorophyll extracted with $15 \mathrm{ml}$ of $80 \%$ acetone. After filtration (double MacheryNagel filter paper No.615), the amount of filtrate (about $15 \mathrm{ml}$ ) was made up to $20 \mathrm{ml}$ with $80 \%$ acetone and the amount of chlorophyll determined as before. All phases of the chlorophyll extraction were performed in cold and dark conditions in order to prevent the chlorophyll from breaking down.

The susceptibility of cultivars was determined as the percent increase of the amount of chlorophyll in the effusate or as the percent decrease of chlorophyll in the leaf segments during the live enzyme incubation compared to the autoclaved control.

\section{C) Leaf segment test}

Plants (50 plants/cultivar) were grown in 5 litre pots containing peat-soil mixture. The plants were cultivated and hardened as described in method A. Segments about $2 \mathrm{~cm}$ in length were cut from the first leaves of the plants. The leaf segments (10 pieces/petri dish, three dishes/cultivar) were then mounted on agar $(0.3 \%)$ containing $60 \mathrm{ppm}$ benzimidazole as described by Benedikz et al. (1981). The leaf segments were inoculated by placing a $2 \mu 1$ drop of $M$. nivale spore suspension $\left(1 \times 10^{6}\right.$ spores $\left.\mathrm{ml}^{-1}\right)$ on the surface. The inoculated leaf segments were incubated either at $+15^{\circ} \mathrm{C}(18 / 6 \mathrm{~h}$ photoperiod, 3000 lux $)$ or at $+6^{\circ} \mathrm{C}$ (constant light, 2000 lux). The amount of damage was estimated using a score of 0 (no damage) to 5 (extensive damage) after 4 and 7 days incubation at $+15^{\circ} \mathrm{C}$ and after 13 and 18 days incubation at $+6^{\circ} \mathrm{C}$. 
The differences among the rye cultivars were studied in all the snow mould tests using the analyses of variance.

\section{Freezing test}

Freezing tests were carried out as described by Larsson (1983), with slight modifications. Plants were cultivated in peat-soil mixture and hardened as described above. Twenty seeds per cultivar were sown in a row, but the trial was not replicated. The duration of the freezing procedure was $72 \mathrm{~h}$ and the lowest temperature during the program was $-16^{\circ} \mathrm{C},(24 \mathrm{~h})$. After the cold treatment, the plants were kept at $+2^{\circ} \mathrm{C}$ in darkness for 24 hours. Survival was determined after a $10 \mathrm{~d}$ recovery period in the greenhouse.

\section{Correlations}

Correlations between the results from the tests performed were determined, to find out whether the tests measure similar kinds of snow mould stress responses of plants.

\section{RESULTS}

\section{Field trials}

In 1991, the winter conditions favoured snow mould development. At Jokioinen and Mietoinen (in southern Finland), the differences in the $M$. nivale resistance among the cultivars were statistically significant, but the severe winter conditions at other locations brought about too much winter damage to plants, and the experimental errors in determining the snow mould damage were too large to allow any statistically significant differentiation among the cultivars (Table 1). Because of the mild winter in 1992, there was no snow mould damage on rye at Mietoinen and Anjalankoski. The best differentiation in snow mould resistance was achieved in central Finland (Pälkäne and Laukaa). At Sotkamo the snow fell on frozen ground, and the development of $M$. nivale was prevented. Only one cultivar, Vågonäs höstråg, was damaged by snow mould, resulting in a high F-value, but the results from Sotkamo were not included in the overall varietal means of snow mould damage.

The overall varietal means of snow mould damage (Table 2) were calculated on the basis of six field trials, in which the differences among cultivars were statistically significant. The most resistant rye cultivars were Norderåstetra and Talovskaja 12, and the most susceptible ones were Kungs II and Dominator (Table 2). 
A. Snow mould chamber tests

The rye cultivars were more severely damaged, and the percent survival was lower, in nutrient solution than in peat-soil mixture (Table 3). The incubation period of nine weeks in the peat-soil was still too short to cause lethal damage even to the most snow mould susceptible rye cultivars. In both treatments, the differences in the amount of snow mould damage among the cultivars were very significant, but only in nutrient solution were significant differences also found in the percent survival of cultivars (Table 3).

In the controls without $M$. nivale inoculation, one hundred percent survival in both treatments was achieved by all cultivars except Anna (95.8 \%, peat-soil) and Jussi ( $92.3 \%$ peat-soil). The amount of snow mould damage to cultivars varied between 0.1 and 0.7 in peat-soil and between 0.0 and 0.1 in nutrient solution. The differences among the cultivars were not statistically significant in the control treatments.

In the snow mould chamber tests, Anna and Jussi were the most resistant and Danko and Epos the most susceptible rye cultivars.

\section{B. Enzymatic assay}

On the basis of viscometric assay, the pectolytic enzyme preparation was very effective (the viscosity of the substrate solution was halved in 50 minutes). The optimal $\mathrm{pH}$ level (pH5) of the fungal growth medium seems to be very important. In preliminary trials, at pH6 there was no enzyme activity and at $\mathrm{pH} 7$ the activity was very low.

The differences in the resistance against lytic enzymes secreted by M.nivale were obvious among the rye cultivars (Table 4). The pectolytic enzymes were more efficient in degrading the leaf segments than the cellulolytic enzymes (Table 4). The leaf segments of susceptible cultivars degraded almost totally during incubation with pectolytic enzymes, while the leaf segments were extensively damaged, but still whole, after treatments with cellulolytic enzymes, or with both enzymes together.

In the case of effusate, the differences among the cultivars were significant in all the treatments, but in leaf segments only the treatment with the enzyme mixture was able to differentiate among the cultivars (Table 4).

The differences between the replications were sometimes very high, covering the differences between the cultivars. This was the case especially in treatments with the more effective pectolytic enzymes (Table 4). The use of live enzymes in screening snow mould resistance of cultivars seems to be somewhat complicated, and more replications are needed to differentiate 
between the cultivars with moderate snow mould resistance. The most enzyme tolerant rye cultivars were Anna and Jussi and the most susceptible ones were Kungs II and Epos.

\section{Leaf segment test}

The leaf segments of rye cultivars were already clearly damaged by snow mould ( $M$. nivale) after 4 days of incubation at $+15^{\circ} \mathrm{C}$, but the development of symptoms was delayed at $+6^{\circ} \mathrm{C}$, where the same level of damage was achieved only after 13 days of incubation (Table 5). On the basis of analyses of variance, differences in snow mould resistance among the cultivars were significant $(p<0.001)$ at both temperatures (Table 5).

In all cultivars, the amount of damage increased during prolonged incubation (Table 5). Very significant positive correlations were obtained between the two incubation periods at both temperatures, indicating that the order of the cultivars did not change much during incubation (Table 6). There was a significant positive correlation between the amount of snow mould damage at $+15^{\circ} \mathrm{C}$ (both incubation periods) and at $+6^{\circ} \mathrm{C}$ after 13 days of incubation (Table 6). The correlation was, however, only moderate after 18 days at $+6^{\circ} \mathrm{C}$. The reason for this might have been the rather big differences among replicates in some cases (Voima, Dominator), but the prolonged incubation at low temperature could have influenced the snow mould resistance of some cultivars, too. For example, Voima and Dominator seemed to lose, and Petkus II and Prima seemed to increase their resistance in relation to the other cultivars, during incubation at $+6^{\circ} \mathrm{C}$.

The most resistant rye cultivars were Kungs II and Danko, and the most susceptible ones were Musketeer and Talovskaja 12.

\section{Freezing test}

Since there were no replications in the freezing test, the results (Table 2) should be interpreted with caution. They are, however, indicative of the cold resistance of the cultivars, and it was interesting to compare the results of the freezing test to the snow mould resistance of cultivars. The most frost hardy rye cultivars were Musketeer and Anna, and the most sensitive ones were Epos and Prima.

\section{Correlations}

In the snow mould chamber test, the significant positive correlation between the percent survival of cultivars grown in either a peat-soil mixture or a nutrient solution indicates that media did not influence the relative survival of the cultivars (Table 7). The significant negative 
correlation between the survival of cultivars and the amount of chlorophyll extracted from leaf segments treated with pectolytic enzymes, and the significant positive correlation between the amount of leaf damage in nutrient solution and the amount of chlorophyll extracted from leaf segments treated with cellulolytic enzymes indicate that both these enzymes are connected to the snow mould resistance of rye cultivars (Table 7). The importance of lytic enzymes is further supported by the significant positive correlations between some of the enzyme treatments and field trials (Table 8). However, the lack of differentiation among the cultivars in both survival in peat-soil and in the treatment with pectolytic enzymes (Tables 3 and 4), as well as the small number of cultivars tested in snow mould chamber, could have also influenced the results of correlation analysis, thus making it difficult to interpret the real importance of fungal enzymes in the snow mould resistance of plants.

There was no significant correlation between the survival in the snow mould chamber test and the snow mould damage on field trials (Table 7). A longer incubation period in the peatsoil might have resulted in larger differences among the cultivars, thus allowing better correlations with field trials and also with other tests.

The results from the leaf segment test (only longer incubation periods were employed in correlation analysis) did not generally correlate with the results from the other tests. The cultivars that seemed to be snow mould resistant according to this test were often the most susceptible ones on the basis of the other tests (Tables 7 and 8).

There was no correlation between snow mould resistance and frost resistance of rye cultivars (Tables 7 and 8), but the lack of replications in the freezing test make this result only tentative.

\section{DISCUSSION}

Field trials are most often employed in screening snow mould resistance. However, the results from field trials are often influenced by the prevailing environmental conditions, and many test years and locations are usually needed to assess reliably the snow mould resistance of cultivars (Miedaner et al., 1993; Pronczuk \& Zagdanska, 1993). The inefficiency of field trials was obvious also in this study, because only six out of twelve trials were able to differentiate the studied rye cultivars on the basis of their resistance to $M$. nivale.

The snow mould chamber method is generally used in screening for snow mould resistance in controlled conditions. Since this method is based on testing snow mould resistance of plants in conditions simulating the field conditions in winter, the snow mould chamber test results should correlate well with the results from field trials. In this study, no significant correlation was found between the survival of cultivars grown in peat-soil and the amount of snow mould 
damage in the field. The relatively low correlation coefficient $(-0.64)$ could be affected by the short incubation period which resulted in poor separation in the percent survival of cultivars, and by the low number of cultivars $(n=8)$ tested in the snow mould chamber. There was no correlation between the amount of leaf damage in the snow mould chamber tests and in the field trials. According to Bruehl (1982) and Miedaner et al. (1993), only the regrowth capacity of plants in the snow mould chamber test correlates with field resistance. Bruehl et al. (1975) stated that only tests in which the most susceptible cultivars are killed or severely damaged are useful. Since the leaves of all cultivars are destroyed in such tests, the amount of leaf damage cannot be used in rating snow mould resistance.

Thus, both the field trials and snow mould chamber tests examine the ability of cultivars to survive under prolonged stress conditions under long lasting snow cover. The differences in snow mould resistance of cultivars might merely describe differences in their hardening ability, rather than a real resistance reaction. This hypothesis could also explain the general opinion that hardening at low temperature is a necessity for the complete induction of snow mould resistance of plants (Årsvoll, 1977; Tronsmo, 1984, 1985).

In spite of numerous studies in which the lytic enzymes produced by plant pathogens have been associated with the maceration and cellular death of host plants (Mount et al., 1969), only a few attempts have been made to use enzymes in screening the disease resistance of cultivars. McBeath (1991) found that the lytic enzymes extracted by Myriosclerotinia borealis could be used in screening the snow mould resistance of winter wheat cultivars. In this study, significant differences were found among the rye cultivars in their resistance to lytic enzymes secreted by M. nivale. In some cases, significant correlations between the results from enzyme treatments, field trials and snow mould chamber tests were also found, indicating that lytic enzymes are involved in the snow mould resistance reactions of plants. The method used was, however, too laborous and complicated to be suitable for practical snow mould resistance breeding.

One aspect of the snow mould resistance might involve the ability to prevent the foliar penetration of mycelia. Takenaka \& Yoshino (1987) found that the resistance of wheat plants was slightly expressed during foliar penetration. Furthermore, Kozowska \& Packa (1986) found clear differences in the ability of snow mould to grow inside different rye varieties and they also found differences in the size and homogenity of leaf epidermal cells among snow mouldresistant and susceptible varieties. Koczowska (1988) found that rye cultivars deployed chemical defences: snow mould infection caused changes in the synthesis of phenols among resistant and susceptible varieties. The resistant cultivars were also characterized by a higher content of benzoxazolinone both before and after infection. 
In the leaf segment test, the snow mould infection pressure was focused in detached leaf segments instead of the whole plants, to find out if some specialized resistance mechanisms occurs at or near the site of mycelia penetration. Significant differences were found among the rye cultivars in their ability to prevent the growth and development of $M$. nivale on their leaves.

The leaf segment tests employed in disease tests for some plant pathogens, e.g., Septoria nodorum (Baker \& Smith, 1978) have usually correlated well with the pathogen resistance of cultivars in field trials. The results from this study are not in agreement with these reports, since $M$. nivale resistance of rye cultivars in leaf segment tests did not correlate with the results from the other tests employed. This indicated that different resistance mechanisms are involved in leaf segment tests than in snow mould chamber tests, and in field trials. The lack of correlation between the leaf segment test and the enzymatic assay suggest that, although lytic enzymes are important tools for the fungus when attacking the host plant, the plant's response to the attack is not dependent only on enzymes secreted by the fungus. There must be other chemical or mechanical triggers for the resistance reactions of plants.

In the present study, there was no correlation between the frost resistance and snow mould resistance of rye cultivars. However, the Nordic winter rye cultivars (Jussi, Anna, Voima, Vågonäs höstråg and Norderåstetra) were both frost and snow mould resistant, indicating that they have been selected in conditions where both characters are of equal importance. According to Årsvoll (1977) and Årsvoll \& Larsen (1977), there is a significant positive correlation between these two traits, but a negative correlation between frost resistance and snow mould resistance was found by Gaudet \& Chen (1988). It is generally assumed that the resistance mechanisms behind these two traits are separate, but they could both be induced by the low temperature hardening (Pronczuk \& Zagdanska, 1993; Tronsmo, 1985).

In conclusion, several mechanisms may be involved in snow mould resistance. Some of them involve the winterhardiness of cultivars, and the snow mould chamber tests probably indicate just this kind of general winterhardiness. However, there might also be some other special forms of snow mould resistance which could be detected by different tests where the infection pressure is focused on different parts of the plants. In this way, the various sources of resistance might be found to be useful to breeders.

ACKNOWLEDGEMENTS: The author thanks Professor Seppo Pulli for his enthusiasm in starting the Inter-Nordic Winterhardiness Project, which made these studies possible, Miss Marja-Leena Manninen and Miss Pia Kallio for their technical assistance and Mrs. Randi Kum- 
pulainen for correcting the English language. The snow mould isolation procedure and storage were carried out at the Institute of Plant Protection, Agricultural Research Centre of Finland.

The spore suspensions employed in these tests were kindly provided by Mr. Asko Hannukkala. I want to thank him also for his advice and discussions on the subject. This study was supported financially by the Samnordic Planteforedling and the Finnish Ministry of Agriculture and Forestry.

\section{REFERENCES:}

Ahmed K.Z., Mesterhazy A. \& Sagi F.(1991) In vitro techniques for selecting wheat (Triticum aestivum L.) for Fusarium resistance. I. Double layer technique. Euphytica 57, 251-157.

Ársvoll K. (1977) Effects of hardening, plant age, and development in Phleum pratense and Festuca pratensis on resistance to snow mould fungi. Meldinger fra Norges LandbrHøgskole 56, $14 \mathrm{pp}$.

Årsvoll K. \& Larsen A. (1977) Effects of nitrogen, phosphorus, and potassium on resistance to snow mould fungi and on freezing tolerance in Phleum pratense. Meldinger fra Norges LandbrHogskole 57, 14pp.

Baker E.A. \& Smith J.M. (1978) Development of resistant and susceptible reactions in wheat on inoculation with Septoria nodorum. Transactions of the British Mycological Society 71, 475-482.

Benedikz P.W., Mappledoram C.J. \& Scott P.R. (1981) A laboratory technique for screening cereals for resistance to Septoria nodorum using detached seedling leaves. Transactions of the British Mycological Society 77, 667-668.

Blomqvist H.H. \& Jamalainen E.A. (1968) Preliminary tests on winter cereal varieties of resistance to low temperature parasitic fungi in controlled conditions. Journal of the Scientific Agricultural Society of Finland 40, 88-95.

Bruehl G.W. (1982) Developing wheats resistant to snow mold in Washington State. Plant Disease 66, 1090-1095.

Bruehl G.W., Kiyomoto R., Peterson C. \& Nagamitsu M. (1975) Testing winter wheats for snow mould resistance in Washington. Plant Disease Reporter 59, 566-570.

Chelkowski J., Golinski P., Perkowski J., Visconti A., Rakowska M. \& Wakulinska W. (1991) Toxinogenecity of Microdochium nivale (Fusarium nivale) isolates from cereals in Poland. Mycotoxin Research 7(A suppl), 140-145.

Chang T.T., Yang X.Y. \& Ko W.H. (1992) A sensitive method for detecting production of extracellular enzymes by fungi on solid media. Mycologia 84, 923-926.

Gaudet D.A. \& Chen T.H.H. (1988) Effect on freezing resistance and low-temperature stress on development of cottony snow mold (Coprinus psychromorbidus) in winter wheat. Canadian Journal of Botany 66, 1610-1615.

Hilbers S., Fischbeck G. \& Jahoor, A. (1992) Localization of the Laevigatum resistance gene Mila against powdery mildew in the barley genome by the use of RFLP markers. Plant Breeding 109, 335-338.

Hipkins M.F. \& Baker N.R. (1987) Spectroscopy. In: Photosynthesis energy transduction: A practical approach. (Ed. by M.F.Hipkins \& N.R. Baker),pp.51-102. IRL Press, Oxford, Washington D.C.

Hoagland D.R. \& Arnon D.I. (1938) The water-culture method for growing plants without soil. California Agricultural Experiment Station Circular. 347, 39pp. 
Hömmö L., Hannukkala A. \& Pulli S. (1992) Screening for resistance of winter wheat and rye varieties to Finnish snow mould (Microdochium nivale) isolates. Hodowla Róslin Aklimatyzacja i Nasiennictwo 37 (special edition nr. 2), 133-139.

Jalli M. (1992) Ohralajikkeiden verkkolaikunkestävyyttä testaavat menetelmät. Master's Thesis, University of Helsinki (in Finnish).

Jamalainen E.A. (1974) Resistance in winter cereals and grasses to low-temperature parasitic fungi. Annual Review of Phytopathology 12, 281-302.

Koczowska I. (1988) The active resistance of rye to snow mould caused by Fusarium nivale (Fr.) Ces.. Acta Academiae Agriculturae ac Technicae Olstenensis 47, 101-111.

Koczowska I. \& Packa D. (1986) Anatomical-physiological resistance of rye plants to infection by Fusarium nivale (Fr.) Ces.. Acta Academiae Agriculturae ac Technicae Olstenensis 43, 129-142.

Larsson S.(1983) An artificial freezing method useful for cold hardiness breeding in winter cereals. Sveriges Utsädesföreningens Tidskrift 93, 299-311 (Swedish with English summary).

Logrieco A., Vesonder R.F. \& Peterson S.W. (1991) Reexamination of the taxonomic disposition of and deoxynivalenol production by Fusarium nivale NRRL 3289. Mycologia 83, 367-370.

McBeath J.F. (1991) In vitro detection of resistance to snow mould fungi. Abstract in NJFSeminar No.188 Às, Norway p.8.

Miedaner T., Höxter H. \& Geiger H.H. (1993) Development of resistance test for winter rye to snow mold (Microdochium nivale) under controlled environment conditions in regard to field inoculations. Canadian Journal of Botany, 71, 136-144.

Mount M.S., Bateman D.F. \& Basham H.G. (1969) Induction of electrolyte loss, tissue maceration, and cellular death of potato tissue by an endopolygalacturonate trans-eliminase. Phytopathology 60, 924-931.

Nakajima T. \& Abe J. (1990) A method for assessing resistance to the snow molds Typhula incarnata and Microdochium nivale in winter wheat incubated at the optimum growth temperature ranges of the fungi. Canadian Journal of Botany 68, 343-346.

Pauk J., Manninen O. \& Pulli S. (1990) In vitro selection approaches against Fusarium disease in wheat. Abstract in VIIth International Congress on Plant Tissue and Cell Culture Amsterdam pp. 162.

Pronczuk M. \& Zagdanska B. (1993) Effect of Microdochium nivale and low temperature on winter survival of perennial ryegrass. Journal of Phytopathology, 138, 1-8.

Stack J.P., Mount M.S., Berman P.M. \& Hubbard J.P. (1980) Pectic enzyme complex from Erwinia carotovora: a model for degradation and assimilation of host pectic fractions.

Phytopathology 70, 267-272.

Takenaka S. \& Yoshino R. (1987) Penetration of Typhula incarnata in wheat plants differing in resistance. Annals of the Phytopathological Society of Japan 53, 566-569.

Takenaka S. \& Yoshino R. (1989) Development of suitable technique for testing resistance of wheat cultivars to three snow mold diseases. Japan Agricultural Research Quarterly 22, 284289.

Tronsmo A.M. (1984) Predisposing effects of low temperature on resistance to winter stress factors in grasses. Acta Agriculturae Scandinavica 34, 210-220.

Tronsmo A.M. (1985) Effects of dehardening on resistance to freezing and to infection by Typhula ishikariensis in Phleum pratense. Acta Agriculturae Scandinavica 35, 113-116.

Yoshida N., Fukushima T., Saito H., Shimosaka M \& Okazaki M. (1989) Cellulose and xylan degrading enzymes of the plant pathogenic fungus, Fusarium oxysporum SUF850. Agricultural and Biological Chemistry 53, 1829-1836. 
Table 1. Analyses of variance for snow mould damage on thirteen winter rye cultivars tested at six locations during 1990-1991.

\begin{tabular}{ll}
\hline Location $\quad$ Year & $\begin{array}{l}\text { F-value for } \\
\text { cultivars }\end{array}$
\end{tabular}

$\begin{array}{llc}\text { Jokioinen } & 1990 & 4.80 \star \star \star \\ & 1991 & 2.71 \star \star \\ \text { Mietoinen } & 1990 & 7.24 * \star \star \\ & 1991 & \text { no snow mould }\end{array}$

$\begin{array}{ccc}\text { Pälkäne } & 1990 & 0.99 \\ & 1991 & 27.06 * * *\end{array}$

$\begin{array}{ccc}\text { Anjalankoski } & 1990 & 1.08 \\ 1991 & \text { no snow mould }\end{array}$

$\begin{array}{lll}\text { Laukaa } & 1990 & 3.34 * * \\ & 1991 & 6.63 * * * \\ \text { Sotkamo } & 1990 & 1.63 \\ & 1991 & 6.30 * \star *\end{array}$

- The tests with significant F-values were used in calculating overall varietal means, except for the test at Sotkamo 1992

$\star \mathrm{p}<0.05, * \star \mathrm{p}<0.01, * \star * \mathrm{p}<0.001$ 
Table 2. The amount of snow mould damage on rye cultivars tested in the field on a scale from 0 (no damage) to 10 (dead). The figures are means of six field trials, selected on the basis of analyses of variance. The frost resistance of the cultivars was determined as the survival rate after the freezing test.

\begin{tabular}{lll}
\hline Variety & $\begin{array}{l}\text { Field damage } \\
\text { Mean SD }\end{array}$ & $\begin{array}{l}\text { Freezing test } \\
\text { Survival } \%\end{array}$ \\
\hline
\end{tabular}

$\begin{array}{lllc}\text { Norderås tetra } & 2.0 & 1.4 & 81.8 \\ \text { Talovskaja 12 } & 2.1 & 1.7 & 23.7 \\ \text { Voima } & 2.2 & 1.6 & 68.8 \\ \text { Jussi } & 2.3 & 1.8 & 75.6 \\ \text { Anna } & 2.5 & 1.6 & 84.8 \\ \text { Vågonäs höstråg } & 3.0 & 2.4 & \text { not done } \\ \text { Prima } & 3.1 & 2.3 & 18.6 \\ \text { Musketeer } & 3.8 & 2.7 & 100.0 \\ \text { Petkus II } & 4.0 & 2.2 & 43.8 \\ \text { Danko } & 4.1 & 2.5 & 82.6 \\ \text { Epos } & 4.1 & 2.1 & 17.5 \\ \text { Dominator } & 4.7 & 2.2 & 30.0 \\ \text { Kungs II } & 5.1 & 2.2 & 51.3\end{array}$


Table 3. The snow mould resistance of rye cultivars as tested in a snow mould chamber. The plants were grown either in peat-soil mixture or in nutrition solution. The amount of leaf damage was rated on a scale from 0 (no damage) to 5 (extensive damage). The figures are means of four replicates, and the statistical significance of the differences in the snow mould resistance of cultivars was tested using the analyses of variance.

\begin{tabular}{|c|c|c|c|c|c|c|c|c|}
\hline \multirow[b]{3}{*}{ Cultivar } & \multicolumn{4}{|c|}{ Peat-soil mixture } & \multicolumn{4}{|c|}{ Nutrient solution } \\
\hline & \multicolumn{2}{|c|}{ Damage } & \multicolumn{2}{|c|}{ Survival \% } & \multicolumn{2}{|c|}{ Damage } & \multicolumn{2}{|c|}{ Survival \% } \\
\hline & Mean & SD & Mean & SD & Mean & SD & Mean & $\mathrm{SD}$ \\
\hline Talovskaja 12 & 1.5 & 1.1 & 90.6 & 7.5 & 2.2 & 1.0 & 49.1 & 12.5 \\
\hline Kungs II & 1.6 & 1.1 & 89.9 & 12.3 & 2.9 & 1.1 & 48.6 & 20.3 \\
\hline Anna & 1.7 & 0.9 & 98.1 & 3.9 & 2.1 & 1.0 & 86.3 & 4.3 \\
\hline Petkus II & 1.7 & 1.0 & 93.9 & 7.9 & 1.4 & 1.0 & 74.6 & 16.3 \\
\hline Jussi & 1.8 & 1.1 & 96.0 & 4.6 & 1.9 & 1.2 & 71.2 & 17.7 \\
\hline Voima & 1.9 & 1.0 & 100.0 & 0.0 & 3.1 & 1.0 & 56.9 & 8.3 \\
\hline Epos & 2.2 & 1.1 & 92.0 & 9.3 & 2.1 & 1.3 & 45.9 & 29.1 \\
\hline Danko & 2.6 & 1.0 & 85.7 & 12.8 & 2.4 & 1.0 & 40.4 & 17.5 \\
\hline
\end{tabular}

F-value

$5.09 * \star *$

1.28

$32.34 * * *$

$3.57 * *$

$\star \mathrm{p}<0.05, * \star \mathrm{p}<0.01, * \star * * \mathrm{p}<0.001$ 


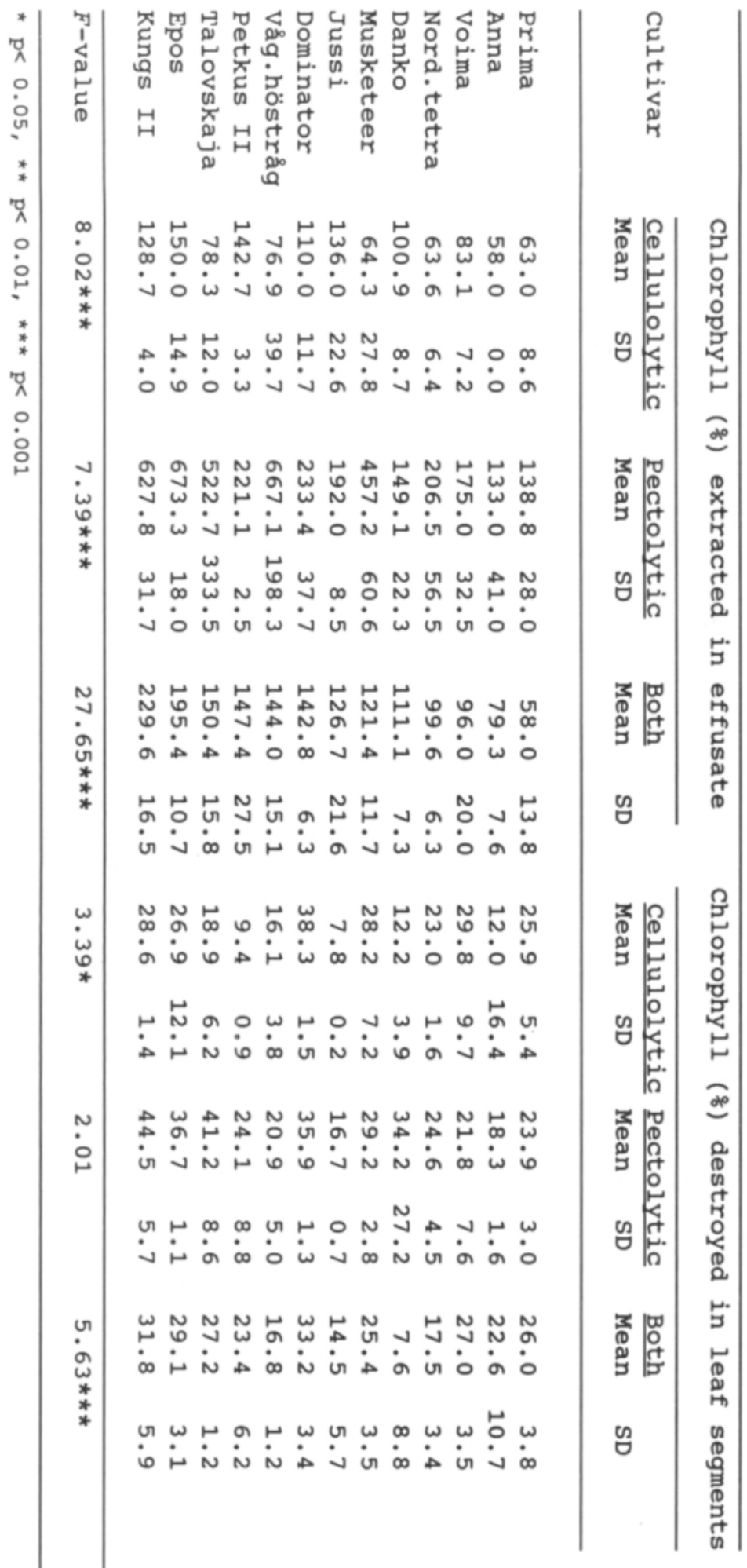

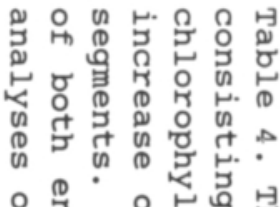

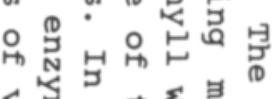

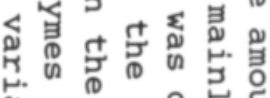

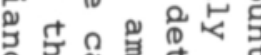

คै

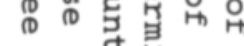

呬南

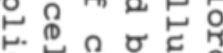

ณ

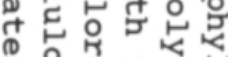

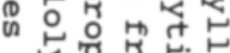

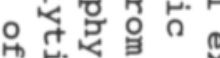

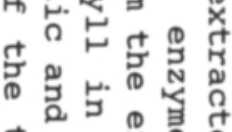

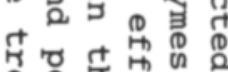

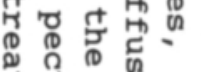

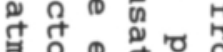

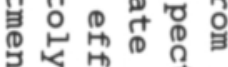

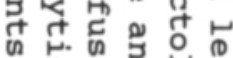

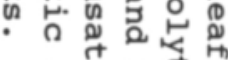

包号它苗

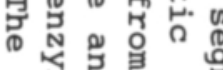

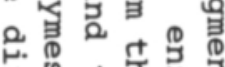

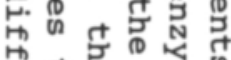

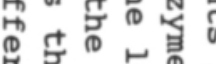

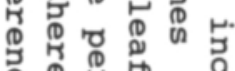

คి

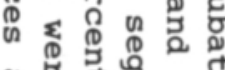

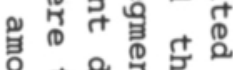

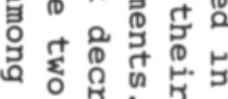

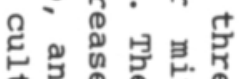

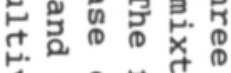

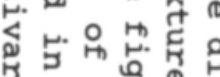

ט 0 疍

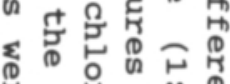

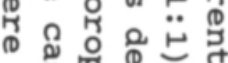

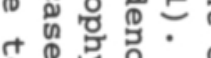

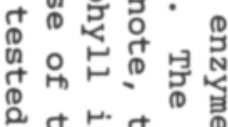

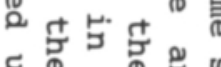

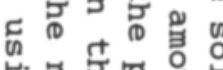

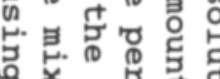

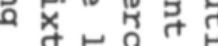

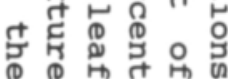


Table 5. Snow mould (M. nivale) resistance of 13 winter rye varieties tested with the leaf segment test. Figures are the means of three petri dishes with 10 leaf segments in each. The scale used in determining the amount of leaf damage was from 0 (no damage) to 5 (extensive damage). The differences among cultivars were tested with analyses of variance.

\begin{tabular}{|c|c|c|c|c|c|c|c|c|}
\hline \multirow{3}{*}{ Cultivar } & \multicolumn{4}{|c|}{ Snow mould damage at $+15^{\circ} \mathrm{C}$} & \multicolumn{4}{|c|}{ Snow mould damage at $+6^{\circ} \mathrm{C}$} \\
\hline & \multicolumn{2}{|c|}{4 days } & \multicolumn{2}{|c|}{7 days } & \multicolumn{2}{|c|}{13 days } & \multicolumn{2}{|c|}{18 days } \\
\hline & Mean & SD & Mean & SD & Mean & SD & Mean & SD \\
\hline Anna & 1.0 & 0.8 & 1.7 & 1.1 & 0.6 & 0.9 & 2.4 & 1.4 \\
\hline Jussi & 0.9 & 1.1 & 1.8 & 1.2 & 0.8 & 1.2 & 1.9 & 1.6 \\
\hline PetkusII & 1.2 & 1.2 & 2.0 & 1.3 & 0.4 & 0.6 & 1.1 & 1.1 \\
\hline Danko & 0.9 & 0.9 & 1.7 & 1.1 & 0.4 & 0.6 & 0.8 & 0.6 \\
\hline Prima & 2.0 & 1.2 & 3.0 & 1.0 & 0.8 & 1.0 & 1.4 & 1.1 \\
\hline Voima & 0.7 & 1.0 & 1.5 & 1.1 & 0.7 & 0.8 & 2.5 & 1.7 \\
\hline Dominator & 0.8 & 1.1 & 1.6 & 1.4 & 0.5 & 0.8 & 2.0 & 2.0 \\
\hline Nord.tetra & 1.2 & 1.0 & 1.9 & 1.2 & 1.4 & 1.0 & 2.8 & 1.6 \\
\hline Talovskaja & 2.1 & 1.3 & 2.9 & 1.2 & 1.7 & 1.3 & 2.5 & 2.0 \\
\hline Kungs II & 0.6 & 0.8 & 1.2 & 1.0 & 0.3 & 0.5 & 1.3 & 1.0 \\
\hline Musketeer & 2.7 & 1.1 & 3.5 & 1.1 & 2.3 & 1.6 & 4.0 & 1.4 \\
\hline Epos & 1.3 & 1.3 & 2.1 & 1.2 & 0.5 & 0.7 & 1.5 & 1.4 \\
\hline våg.höstråg & 2.4 & 1.2 & 3.2 & 1.1 & 0.8 & 0.9 & 2.6 & 1.4 \\
\hline$F$-value & 12.21 & 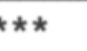 & 11.73 & $k * *$ & 11.3 & 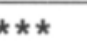 & 10.73 & $\star \star \star *$ \\
\hline
\end{tabular}

$\star \star \star \mathrm{p}<0.001$

Table 6. Correlations between results for the different incubation treatments in the leaf segment test.

$\frac{\text { Incubation at }+15^{\circ} \mathrm{C}}{4 \text { days } \quad 7 \text { days }} \quad \frac{\text { Incubation at }+6^{\circ} \mathrm{C}}{13 \text { days } 18 \text { days }}$

\begin{tabular}{|c|c|c|c|c|}
\hline 4 days $+15^{\circ} \mathrm{C}$ & 1.00 & $0.99 * * *$ & $0.72 * *$ & 0.55 * \\
\hline 7 days $+15^{\circ} \mathrm{C}$ & & 1.00 & $0.69 \star \star$ & $0.53 *$ \\
\hline 13 days $+6^{\circ} \mathrm{C}$ & & & 1.00 & $0.83 * \star \star$ \\
\hline 18 days $+6^{\circ} \mathrm{C}$ & & & & 1.00 \\
\hline
\end{tabular}

* $\mathrm{p}<0.05,{ }^{\star *} \mathrm{p}<0.01,{ }^{\star \star \star *} \mathrm{p}<0.001 \quad(\mathrm{n}=13)$ 
Table 7: Correlations among methods for assessing resistance to M. nivale.

Peat-soil mixture

Survival Leaf damage
Nutrient solution

Survival Leaf damage

Snow mould chamber test

Peat-soil mixture

Survival

Leaf damage

1.00

$-0.43$

0.71 *

0.00

1.00

$-0.48$

0.10

Nutrient solution

Survival

Leaf damage

$1.00-0.53$

1.00

Enzymatic assay

Chlorophyll in effusate

cellulolytic

Pectolytic

Both

In leaf segments

Cellulolytic

Pectolytic

Both

\section{Leaf segment test}

$+15 \mathrm{C}$
$+6 \mathrm{C}$

Freezing test

Field trials

$\begin{array}{rrrr}-0.28 & 0.17 & -0.20 & -0.30 \\ -0.40 & -0.20 & -0.55 & 0.19 \\ -0.49 & -0.17 & -0.48 & 0.11\end{array}$

0.04

$-0.04$

0.03

$-0.54$

-0.79 **

0.79 * *

$-0.61$

$-0.03$

0.34

0.26

$-0.17$

$-0.58$

-0.10
0.20

$-0.49$

0.48

0.24

0.39

0.16

0.25

0.30

$-0.39$

0.06

$\star p<0.05, * \star p<0.01, * \star \star p<0.001 \quad(n=8)$ 


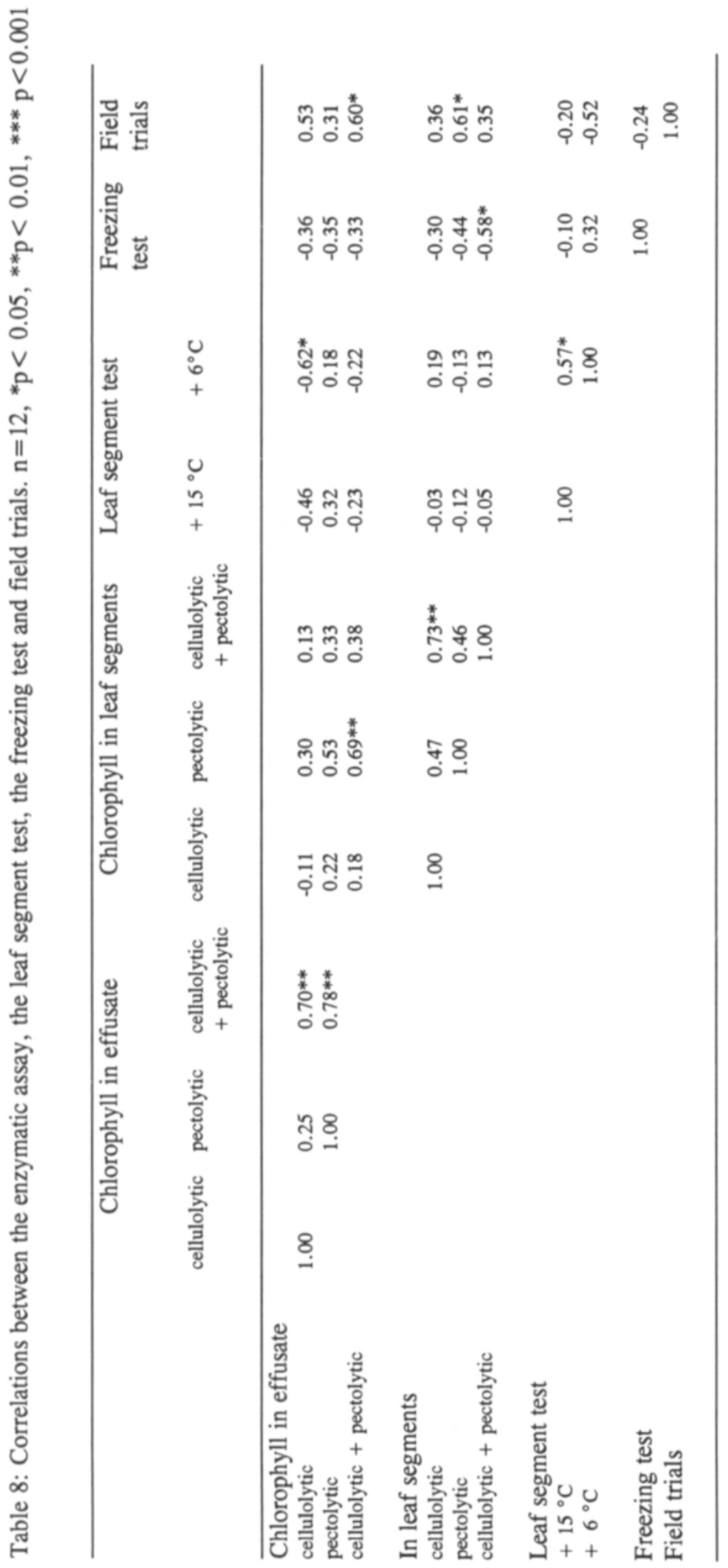



EFFECT OF HARDENING AND DEHARDENING ON SNOW MOULD RESISTANCE

EFFECT OF HARDENING AND DEHARDENING ON SNOW MOULD (Microdochium nivale) RESISTANCE OF WINTER WHEAT

Hömmö, L.M.

Agricultural Research Centre of Finland

Institute of Plant Breeding

SF-31600 Jokioinen, Finland

Manuscript submitted 


\section{SUMMARY}

It is generally assumed that hardening of plants in subfreezing temperatures is necessary for the induction of snow mould resistance. Screening for snow mould resistance has, however, almost completely been limited to the use of field trials or snow mould chamber tests. A shortcoming of these methods is that the differences found in the general winterhardiness of plants may obscure the differences in their snow mould resistance. The present study examined the effect of hardening and dehardening on the snow mould (Microdochium nivale) resistance of winter wheat. Detached leaf segments were studied instead of the whole plants to determine if there are some snow mould resistance mechanisms that act at or near the site of mycelia penetration independently of the general whole plant resistance system, and if winter wheat cultivars differ from each other in this respect. Clear differences were found among the winter wheat cultivars in their snow mould resistance as expressed at the single leaf level. In most cases, this kind of resistance was independent of or merely repressed rather than induced by low temperature hardening. 


\section{INTRODUCTION}

The winter conditions throughout the area of winter wheat cultivation in Finland (snow cover 120-140 days) frequently favour the growth and development of the pink snow mould, Microdochium nivale (Fries) Samuels \& Hallet, which is the most important causal agent of snow mould damage to winter cereals in Finland (Jamalainen, 1974).

Although pronounced differences in snow mould resistance have been encountered among winter wheat accessions (Amano \& Osanai, 1983; Bruehl, 1982; Gaudet \& Kozub, 1991; Litschko et al., 1988), permitting breeding for resistance, the snow mould resistance of commercially grown cultivars remains inadequate. One reason for this might be that field trials and snow mould chamber tests have been generally employed for the evaluation of the snow mould resistance of plants. Both methods are, however, based on the same principle of testing the snow mould resistance of plants by subjecting them to the stress conditions which prevail in the field during the winter. Accordingly, it might be possible that both tests characterize more the general winter survival ability of plants rather than their specific snow mould resistance.

Detached leaf segments are frequently used in disease tests for some pathogens, for example, Septoria nodorum Berk. ex Berk. (Benedikz et al., 1981), but snow mould tests have been almost completely confined to the use of whole, growing plants. The reaction of rye cultivars to foliar infection by $M$. nivale was studied by Hömmö (1993a) using detached leaf segments, and the differences among these cultivars were expressed at the single leaf level.

It has generally been assumed that the hardening of plants in subfreezing temperatures leads to an increased resistance to snow mould fungi, freezing and other winter stress factors (Årsvoll, 1977; Bruehl \& Cunfer, 1971; Gaudet \& Chen, 1987; Gaudet \& Kozup, 1991; Tronsmo, 1984a, 1984b, 1985, 1993).

The snow mould resistance of plants in field conditions and in snow mould chamber tests has been suggested to be connected with carbohydrate metabolism during the hardening period and the long incubation period under the snow cover (Amano \& Osanai, 1983; Årsvoll \& Larsen, 1977; Bengtsson, 1989; Bruehl \& Cunfer, 1971; Kiyomoto \& Bruehl, 1977). In addition, the size and developmental stage of plants have been found to be important (Årsvoll, 1977; Bruehl, 1982; Gaudet \& Chen, 1987; Jamalainen, 1974). Accordingly, the survival of the crown tissue over the snow mould incubation period is the basic principle of snow mould resistance, and snow mould 
resistance could be considered as the regrowth capacity of a plant from the crown tissue after snow mould incubation (Bruehl, 1982; Litschko et al., 1988; Miedaner et al., 1993). Gaudet \& Kozub (1991) have also presented that snow mould resistance is expressed as the delayed infection of the crown tissues rather than as an immunity reaction at or near the penetration site. However, it might be possible that both field trials and the snow mould chamber tests basically describe the general winter survival abilities of cultivars, rather than characterize the pure snow mould resistance reactions of them.

There might, however, also be various other, more specific snow mould resistance mechanisms in plants, which are not perhaps elucidated by field trials or snow mould chamber tests. Microdochium nivale infects plants also during the growing season, causing brown footrot, leaf necrosis and ear blight (Daamen et al., 1991; Ellen \& Langerak, 1987; Häni, 1981) and, in these cases, the differences in the resistance reactions are not dependent on the hardening and winter survival of the plants.

Årsvoll (1977), Årsvoll \& Larsen (1977) and Meyer (1986) have reported that there is a positive correlation between the frost and snow mould resistance. Larsen (1977) suggested that these two traits might have undergone coadaptation in northern conditions. Numerous reports have indicated, however, that there is no common resistance mechanism behind the frost and snow mould resistance of plants (Bengtsson, 1989; Bruehl \& Cunfer, 1971; Gaudet \& Chen, 1987; Pronczuk \& Zagdanska 1993; Tronsmo, 1984a, 1984c, 1985), and that these traits might even be negatively correlated in some conditions (Gaudet \& Chen, 1988; Gaudet et al., 1989; Gaudet \& Kozub, 1991). Tronsmo (1984b) found a close correlation between unhardened and hardened plants in their resistance to Typhula ishikariensis Imai, and concluded that hardening might activate some general resistance mechanisms which, in turn, increase resistance to snow moulds, and to other diseases.

According to Gaudet et al. (1989), the inoculation of hardened winter wheat plants with Coprinus psychromorbidus Redhead \& Traquair resulted in extensive infection, even though the freezing resistance of the plants was at its maximum. Thus, snow mould resistance is probably not directly dependent on hardening, but hardening might increase the level of pre-existing resistance.

This study sought to clarify the role of cold hardening in the induction of snow mould resistance in winter wheat. The disease reaction of 24 winter wheat cultivars was assayed, using detached leaf segments (Hömmö, 1993a), before hardening, after a 4- 
week hardening period, during dehardening, and the correlations with a snow mould chamber test, a freezing test and field trials were determined. Detached leaf segments were used instead of the complex system of whole growing plants, in order to better elucidate the primary resistance reactions of plants during a fungal attack.

\section{MATERIALS AND METHODS}

The names and origins of the winter wheat cultivars used in this study are listed in Table 3.

\section{Test with unhardened plants}

Plants were sown in 3 litre pots containing a peat-soil mixture and grown in a greenhouse $\left(+20^{\circ} \mathrm{C} /+10^{\circ} \mathrm{C}, 18 / 6 \mathrm{~h}\right.$ photoperiod, $\left.12000 \mathrm{lux}\right)$ until the two leaf stage. Segments about $2 \mathrm{~cm}$ in length were cut from the first leaves of the plants. The leaf segments (10 pieces/petri dish, two dishes/cultivar) were mounted on agar $(0,3 \%)$ containing 60ppm benzimidazole (Benedikz et al. 1981) and inoculated by placing a $10 \mu 1$ drop of Microdochium nivale spore suspension $\left(1 \times 10^{6}\right.$ spores $\left.\mathrm{ml}^{-1}\right)$ onto the surface. The incubation was carried out at $+15^{\circ} \mathrm{C}(18 / 6 \mathrm{~h}$ photoperiod, $3000 \mathrm{lux})$ and the amount of damage assessed after 4,7 and 9 days on a scale of 0 (no damage) to 5 (extensive damage).

\section{Test with hardened plants:}

The plants were grown as described above and hardened for 4 weeks at $+2^{\circ} \mathrm{C}(12 / 12$ h photoperiod, 4000 lux). The leaf segments were cut and treated as above, but the incubation was carried out at $+6^{\circ} \mathrm{C}$ (in constant light, 2000 lux). The amount of damage to the leaf segments was assessed after 11 and 18 days of incubation. Longer incubation periods were used because of the slower development of the symptoms.

\section{Test in dehardening conditions}

The plants were cultivated, hardened and treated as in test 2 , but the incubation of inoculated leaf segments was carried out at $+15^{\circ} \mathrm{C}$ as described in test 1 . The amount of damage to the leaves was assessed after 4,7 and 11 days of incubation. 
4. Snow mould chamber test

Eight winter wheat cultivars ('Linna', 'Vakka', 'Aura', 'Norstar', 'Kosack', 'Folke', 'Hildur' and 'Solid') were sown in rows in plastic boxes filled with a peat-soil mixture. There were four replicates (boxes), and one box as a control without the $M$. nivale inoculation. The cultivars (15 seeds) were sown in one row in each of the boxes and the order of the cultivars was randomized within the replicate. To avoid the border effect, the first and the last row was sown with cultivar 'Vakka', and left unanalyzed.

The plants were grown and hardened as in test 2 . The inoculum was sprayed onto the test plants using a hand sprayer, after which the boxes were covered with moistened cellulose wadding and plastic sheeting as described by Blomqvist \& Jamalainen (1968) and Årsvoll (1977). After an incubation period of 9 weeks at $+2^{\circ} \mathrm{C}$, the plants were rated on a scale of 0 (undamaged) to 5 (extensive damage). The survival rate was calculated from the number of plants that survived after a $10-d$ recovery period in the greenhouse.

A mixture (1:1:1) of three isolates of $M$. nivale (FN61, FN62 and 93/06) collected from Jokioinen and Pälkäne, was used as the inoculum in all tests. The snow mould samples were isolated as pure cultures from infected plant tissue and then stored at $-80^{\circ} \mathrm{C}$ for further use (Hömmö et al., 1993).

Analysis of variance was used to ascertain whether the differences among the cultivars were significant. The correlations between the results from the various tests were also determined.

\section{Freezing test}

The freezing test was carried out as described by Larsson (1983), with some modifications. The test plants were grown and hardened as described above. Twenty seeds per cultivar were sown in a row, but the trial was not replicated. The duration of the freezing procedure was $72 \mathrm{~h}$ and the lowest temperature during the program was $-16^{\circ} \mathrm{C}$, (24h). After the frost treatment the plants were kept at $+2^{\circ} \mathrm{C}$ in darkness for 24 hours. The percent survival was determined after a $10 \mathrm{~d}$ recovery period in the greenhouse.

\section{Field trials:}

The field trials were part of the Inter-Nordic "Winterhardiness" Project and they are described in detail by Hömmö \& Pulli (1993). Artificial snow mould inoculation was not used. In the spring, as soon as the snow had melted, the percent survival of each 
cultivar was determined and the snow mould damage was rated on a scale of 0 (totally undamaged plant) to 10 (dead plant).

The overall means of snow mould damage for cultivars were determined on the basis of only those field trials in which the differences in the snow mould resistance among the cultivars were statistically significant based on the analysis of variance. These means were used in the correlation analysis.

The Field Survival Indexes (Hömmö, 1993b) were determined for the studied cultivars by the method developed by Fowler \& Gusta (1979). On the basis of the analysis of variance, only field trials in which differences in winter survival among the experimental cultivars were statistically significant were accepted for these determinations.

\section{RESULTS}

The differences among cultivars in snow mould resistance were statistically highly significant in all three treatments (unhardened, hardened and dehardened) (Table 1), indicating that resistance reactions are activated in detached leaf segments during an attack of snow mould, and that winter wheat cultivars differ from each other in the intensity of these reactions.

The development of snow mould symptoms on cold hardened leaf segments was delayed when the incubation was carried out at $+6^{\circ} \mathrm{C}$, but in dehardening conditions $\left(+15^{\circ} \mathrm{C}\right)$ there was no difference between the hardened and unhardened leaves. In general, the leaf segments of unhardened plants were less damaged by snow mould and the symptoms were more distinct (clear necrotic spots). The hardened and dehardened leaves suffered mainly from chlorosis caused by the fungus and they turned yellow during the incubation. For this reason assessment of damage was somewhat difficult in some cases, resulting in rather large standard deviations (Table 1).

The snow mould resistance of unhardened cultivars did not correlate with the resistance of the hardened and dehardened ones, while there was a significant positive correlation between the last two treatments (Table 2). This indicates that cold hardening affects the snow mould resistance of winter wheat, and that in most cases the differences in snow mould resistance between hardened winter wheat cultivars are preserved also during the dehardening process. However, the snow mould resistance of some cultivars seemed to differ depending on the particular treatment. Hardening improved 
snow mould resistance in e.g., 'Albidom 12', 'Apollo', 'Aura', 'Holme', 'Kharkov 22 MC', 'Longbow', 'Solid' and 'Vakka', and this improvement was maintained also during dehardening in 'Apollo', 'Aura' and 'Kharkov 22 MC' (Table 1). After hardening, 6 cultivars became more susceptible to snow mould (Table 1).

The level of snow mould resistance of some cultivars changed during the prolonged incubation (Table 1). The resistance of some cultivars was already poor at the beginning of the treatment (e.g. unhardened 'Kharkov $22 \mathrm{MC}$ ', 'Norstar' and 'Rida', hardened 'Goertzen 5559', 'Norstar' and 'Rida', and dehardened 'Frederick', 'Longbow' and 'Skjaldar'). Some cultivars had strong resistance at the very beginning, but the resistance broke down rather quickly (e.g. hardened 'Aura', 'Folke', 'Kharkov 22 MC' and 'Skjaldar' and dehardened 'Albidom 12', 'Gawain', 'Holme' and 'Solid'), and the best cultivars remained resistant througout the incubation period (e.g. 'Kosack', 'Kraka' and 'Walde'). There were no clear cases in which extensive damage at the beginning of the incubation induced a strong resistance reaction in the plant, resulting in the cessation of the growth of the fungus.

In the snow mould chamber test there were significant differences in the amount of snow mould damage among the cultivars (Table 3 ). However, survival of all cultitivars was very high, and the differences among cultivars were not significant (Table 3).

The determination of snow mould resistance of cultivars in field conditions is often rather problematic. Likewise in this study, only in five of ten trials was it possible to differentiate the cultivars on the basis of their snow mould resistance (Table 4). The cold winter of 1990-1991, with its protracted snow cover, favoured the development of snow mould in the southern Finland and screening for snow mould resistance was effective at the southernmost test locations (Mietoinen and Jokioinen). However, the winter was too severe for winter wheat in the other locations, and this led to large experimental errors which obscured the possible differences in the resistance of the cultivars. In 1991-1992, a mild winter resulted in no damage to winter wheat at Mietoinen, and slight, but significant snow mould damage at Jokioinen. The best differentiation in snow mould resistance was achieved in the central regions of the country (Pälkäne, Laukaa). At Sotkamo, the ground was deeply frozen before the snow fell, and the development of snow mould was inhibited, resulting in minor damage.

The data from the five trials in which significant differences were obtained, were used to calculate mean snow mould resistance for the cultivars. The means varied between 1.8 ('Sleipner') and 4.7 ('Gawain') (Table 3). 
The Field Survival Indexes (Table 3) were used to measure the general winter survival abilities of the cultivars. The Finnish winter wheat, 'Linna', was the most winter hardy cultivar in the present study. No correlation was obtained between the amount of snow mould damage to the cultivars in field and their FSI-values (Table 5).

Since the freezing test was performed without replication, the results (Table 3) should be interpreted with caution. There was, however, a significant positive correlation between the frost resistance of the cultivars and their FSI- values (Table 5), indicating that good frost resistance has an important role in winterhardiness.

The survival of cultivars in the freezing test did not correlate with their snow mould resistance as tested either in field or laboratory conditions (Table 5).

On the whole, the results obtained from the leaf segment test did not correlate with those of the snow mould chamber test or with the field trial results (Table 5). The negative correlation between the damage to unhardened plants caused by snow mould and their survival in the snow mould chamber test (Table 5) might have been coincidental, since the differences in the percent survival in the snow mould chamber were not statistically significant (Table 3 ).

The results from the snow mould chamber test did not correlate with the amount of snow mould damage in the field trials, but there were moderate correlations with the FSI-values (Table 5). The differences among the eight experimental cultivars in the amount of snow mould damage caused in the field conditions were rather small and thus resulted in poor correlations. However, the differences in the FSI-values among the cultivars were greater and the correlations were also higher (Table 3).

\section{DISCUSSION}

In this study, differences in snow mould ( $M$. nivale) reactions in leaf segments of unhardened, hardened and dehardened winter wheat cultivars were statistically significant, indicating that resistance to $M$. nivale does exist in detached leaf segments, and that winter wheat cultivars differ from each other in the intensity of these reactions. Such resistance could be based on structural differences among resistant and susceptible cultivars (Koczowska \& Packa, 1986), or on some chemical defence reactions (Koczowska, 1988; Virtanen \& Hietala, 1955; Tronsmo et al., 1993).

Snow mould symptoms developed more slowly on hardened leaf segments incubated at $+6^{\circ} \mathrm{C}$, but in both unhardened and hardened leaf segments incubated at $+15^{\circ} \mathrm{C}$, the 
symptoms were already very distinct after 4 days of incubation. The delay at $+6^{\circ} \mathrm{C}$ could be explained by the slower fungal development at low temperatures. Nakajima \& Abe (1990) and Takenaka \& Yoshino (1989) were able to shorten the incubation time in snow mould chamber test, using $+15^{\circ} \mathrm{C}$ during incubation, and they considered this temperature optimal for the development and function of $M$. nivale.

In general, leaf segments of unhardened plants were less severely damaged by the snow mould, and the symptoms on the leaves were more distinct (clear necrotic spots). The leaves of hardened plants suffered mostly from chlorosis, and they turned yellow during the incubation at both temperatures. The leaves of some cultivars turned yellow more easily when incubated at a rather low light intensity (only 2000 lux at $+6^{\circ} \mathrm{C}$ ). According to Bruehl (1967a) and Bruehl \& Cunfer (1971), snow mould resistant winter wheat accessions turned yellow more rapidly than susceptible ones when incubated in darkness. Although there were differences among the cultivars, this correlation was not observed in this study.

According to Tronsmo (1984b), there is a close correlation between unhardened and hardened plants of timothy or reed canary grass in their resistance to Typhula ishikariensis. In the present study, no correlation was found between the snow mould resistance of the unhardened and hardened winter wheat cultivars.

In fully hardened grasses the enhanced snow mould resistance could be retained even after two weeks in a dehardening environment (Tronsmo 1984c, 1985). The results of this study were in agreement with that, to the extent that snow mould resistance was enhanced in 12 cultivars when incubated at $+6^{\circ} \mathrm{C}$ and in 14 cultivars when incubated at dehardening conditions. However, the resistance of 6 cultivars decreased at $+6^{\circ} \mathrm{C}$ and also at $+15^{\circ} \mathrm{C}$. It is possible that the synthesis of some compounds which are important for defence reactions was disturbed during the hardening at low temperatures and lead to the decreased level of snow mould resistance.

The Field Survival Indexes (FSI) correlated positively with the frost resistance of the cultivars, and with the survival of cultivars in the snow mould chamber test. There was also a significant negative correlation between the FSI values and the amount of snow mould damage to the cultivars in snow mould chamber. Thus, the field survival of winter wheat seems to depend on both the frost resistance and the snow mould resistance of the cultivar. The FSI values did not correlate with the amount of snow mould damage on cultivars in field. However, the cultivars were extensively damaged by snow mould in only two of the five trials (Hömmö \& Pulli, 1993), and this may have 
obscured the real differences in the snow mould resistance. Significant negative correlation $\left(-0.54^{* *}\right)$ was found between the FSI values and snow mould damage in field, if only these two trials were included in the calculations.

According to Tronsmo (1984b and 1984c), Gaudet \& Chen (1988) and Pronczuk \& Zagdanska (1993), both abiotic and biotic stress factors may predispose plants to other winter stresses. Thus, under field conditions, the amount of snow mould damage to a cultivar may be affected by its resistance to frost and other abiotic stress factors, and the primary reason for winter kill remains often obscure.

The snow mould resistance of the cultivars in the field did not correlate with the results of the snow mould chamber test. The overly short incubation period, which did not differentiate the cultivars in their percent survival, might explain the lack of a correlation, since according to Miedaner et al. (1993), the regrowth ability of cultivars in the snow mould chamber test is the most important indicator of snow mould resistance in field conditions.

The results from the leaf segment test did not correlate with those from the snow mould chamber test or the field trials. This is in accordance with the results obtained from the leaf segment test with rye cultivars (Hömmö, 1993a). This may be because the leaf segment test is based on a different kind of snow mould resistance mechanism than that of the field trials or snow mould chamber tests.

According to Bruehl (1982), Bruehl et al. (1966), Bruehl et al. (1975) and Kiyomoto \& Bruehl (1977) a plant's resistance to snow mould fungi is polygenic and nonspecific. Snow mould pathogens have little pathogenic specialization, and the plant's resistances to different snow mould pathogens are correlated (Amano \& Osanai, 1983; Bruehl, 1967b and 1967c; Gaudet \& Chen, 1988; Jamalainen, 1974; Meyer, 1986). However, poor general winterhardiness could also explain the unspecialized nature of the snow mould resistance of plants in field trials and snow mould chamber tests, since weakened plants have no energy left for defence reactions when attacked by different snow moulds. Selection for general winterhardiness, instead of pure snow mould resistance, could also explain the slow progress in the breeding of snow mould resistant varieties (Miedaner et al., 1993).

However, there also appeared to be some specific snow mould resistance mechanisms in the leaves of winter wheat which were not enhanced, but depressed by cold hardening. This kind of snow mould resistance might be a part of some general disease resistance mechanisms such as the ability of plants to prevent the foliar penetration of 
pathogen mycelia by some enzymes (chitinase) or by various toxic substances. The combination of this type of specific snow mould resistance with the more general snow mould tolerance, as determined in snow mould chamber tests or field trials, might improve the snow mould resistance of newly developed winter wheat cultivars.

ACKNOWLEDGEMENTS: The author thanks Professor Seppo Pulli, Head of the Institute of Plant Breeding, for making these studies financially possible and for providing continual encouragement during this work, Miss Marja-Leena Manninen for her technical assistance and Mrs. Randi Kumpulainen for correcting the English language. The snow mould isolation procedure and storage took place at the Institute of Plant Protection, Agricultural Research Centre of Finland. The spore suspensions employed in these tests were kindly provided by Mr. Asko Hannukkala. I want to thank him also for fruitful discussions on the subject. This study was supported financially by the Samnordic Planteforedling and the Finnish Ministry of Agriculture and Forestry.

\section{REFERENCES:}

Amano Y. \& Osanai S.I. (1983) Winter wheat breeding for resistance to snow mold and cold hardiness III. Varietal differences of ecological characteristics on cold acclimation and relationships of them to resistance. Bulletin of Hokkaido Prefectural Agricultural Experimental Stations 50, 83-95.

Årsvoll K. (1977) Effects of hardening, plant age, and development in Phleum pratense and Festuca pratensis on resistance to snow mould fungi. Meldinger fra Norges LandbrHogskole 56, 14pp.

Årsvoll K. \& Larsen A. (1977) Effects of nitrogen, phosphorus, and potassium on resistance to snow mould fungi and on freezing tolerance in Phleum pratense. Meldinger fra Norges LandbrHøgskole 57, 14pp.

Benedikz P.W., Mappledoram C.J. \& Scott P.R. (1981) A laboratory technique for screening cereals for resistance to Septoria nodorum using detached seedling leaves. Transactions of the British Mycological Society 77, 667-668.

Bengtsson B. (1989) Soluble sugar changes during winter and resistance to snow mould in winter wheat. Journal of Phytopathology 124, 162-170.

Blomqvist H.H. \& Jamalainen E.A. (1968) Preliminary tests on winter cereal varieties of resistance to low temperature parasitic fungi in controlled conditions. Journal of the Scientific Agricultural Society of Finland 40, 88-95.

Bruehl G.W. (1967a) Effect of plant size on resistance to snowmold of winter wheat. Plant Disease Reporter 51, 815-819.

Bruehl G.W. (1967b) Correlation of resistance to Typhula idahoensis, T. incarnata, and Fusarium nivale in certain varieties of winter wheat. Phytopathology 57, 308310.

Bruehl G.W.(1967c) Lack of significant pathogenic specialization within Fusarium nivale, Typhula idahoensis, and T. incarnata and correlation of resistance in winter wheat to these fungi. Plant Disease Reporter 51, 810-814.

Bruehl G.W. (1982) Developing wheats resistant to snow mold in Washington State. Plant Disease 66, 1090-1095. 
Bruehl G.W. \& Cunfer B. (1971) Physiologie and Environmental factors that affect the severity of snow mold of wheat. Phytopathology 61, 792-799.

Bruehl G.W., Kiyomoto R., Peterson C. \& Nagamitsu M. (1975) Testing winter wheats for snow mold resistance in Washington. Plant Disease Reporter 59, 566-570.

Bruehl G.W., Sprague R., Fischer W.P., Nagamitsu M., Nelson W.L. \& Vogel O.A. (1966) Snow molds of winter wheat in Washington. Washington State University Agricultural Experiment Station Bulletin 677, 21p.

Daamen R.A., Langerak C.J. \& Stol W. (1991) Surveys of cereal diseases and pests in the Netherlands. 3. Monographella nivalis and Fusarium spp. in winter wheat fields and seed lots. Netherlands Journal of Plant Pathology 97, 105-114.

Ellen J. \& Langerak C.J. (1987) Effects of plant density and nitrogen fertilization in winter wheat (Triticum aestivum L.). 2. Incidence of Gerlachia nivalis and Fusarium spp. related to yield losses. Netherlands Journal of Agricultural Science 35, 155-162.

Fowler D.B. \& Gusta L.V. (1979) Selection for winterhardiness in wheat. I. Identification of genotypic variability. Crop Science 19, 769-772.

Gaudet D.A., Bhalla M.K., Clayton G.W. \& Chen T.H.H. (1989) Effect of cottony snow mold and low temperatures on winter wheat survival in central and northern Alberta. Canadian Journal of Plant Pathology 11, 291-296.

Gaudet D.A. \& Chen T.H.H. (1987) Effects of hardening and plant age on development of resistance to cottony snow mold (Coprinus psychromorbidus) in winter wheat under controlled conditions. Canadian Journal of Botany 65, 1152-1156.

Gaudet D.A. \& Chen T.H.H. (1988) Effect on freezing resistance and low-temperature stress on development of cottony snow mold (Coprinus psychromorbidus) in winter wheat. Canadian Journal of Botany 66, 1610-1615.

Gaudet D.A. \& Kozub G.C. (1991) Screening winter wheat for resistance to cottony snow mold under controlled conditions. Canadian Journal of Plant Science 71, 957965.

Häni F. (1981) Zur Biologie und Bekämpfung von Fusariosen bei Weizen und Roggen. Phytopathologische Zeitschrift 100, 44-87.

Hömmö L. (1993a) Screening winter rye varieties for snow mould (Microdochium nivale) resistance. Plant Pathology, in press.

Hömmö L. (1993b) Progression of hardening during autumn and the final winter survival of some winter wheat (Triticum aestivum L.), Rye (Secale cereale L.), Triticale (X Triticosecale Wittmack.) and winter barley (Hordeum vulgare L.) varieties in Finland. Plant Breeding, in press.

Hömmö L., Hannukkala A. \& Pulli S. (1993) Screening for resistance of winter wheat and rye varieties to Finnish snow mould (Microdochium nivale) isolates. Hodowla Roslin Aklimatyzacja i Nasiennictwo 37 (Special issue Nr. 2), 133-140.

Hömmö L. \& Pulli S. (1993) Winterhardiness of some winter wheat (Triticum aestivum), rye (Secale cereale), triticale ( $X$ Triticosecale) and winter barley (Hordeum vulgare) cultivars tested at six locations in Finland. Agricultural Science in Finland 2, 311-327.

Jamalainen E.A. (1974) Resistance in winter cereals and grasses to low-temperature parasitic fungi. Annual Review of Phytopathology 12, 281-302.

Kiyomoto R.K. \& Bruehl G.W. (1977) Carbohydrate accumulation and depletion by winter cereals differing in resistance to Typhula idahoensis. Phytopathology 67, 206211.

Koczowska I. (1988) The active resistance of rye to snow mould caused by Fusarium nivale (Fr.) Ces.. Acta Academiae Agriculturae ac Technicae Olstenensis 47, 101111. 
Koczowska I. \& Packa D. (1986) Anatomical-physiological resistance of rye plants to infection by Fusarium nivale (Fr.) Ces.. Acta Academiae Agriculturae ac Technicae Olstenensis 43, 129-142.

Larsen A. (1977) Testing av frosttolerance hos gras og sammenheng mellom frosttolerance og resistens mot lav temperatursopper. Nordisk Jordbruksforskning 59, 63-64. (in Norwegian).

Larsson S. (1983) An artificial freezing method useful for coldhardiness breeding in winter cereals. Sveriges Utsädesforeningens Tidskrift 93, 299-311 (in Swedish with English summary).

Litschko L.D., Burbee L.L., Goylty L.G., Hunt L.A. \& McKersie B.D. (1988) An evaluation of winter wheat for resistance to the snow mold fungi Microdochium nivale (Fr.) Samu \& Hall and Typhula ishikariensis Imai. Canadian Plant Disease Survey, 68, 161-168.

Meyer J. (1986) Testing snow mould resistance in winter cereals. NJF Seminar Nr. 84, Lantbruksväxternas överwintring 4-6 juni 1986, Jokioinen, Finland, pp. 139-144.

Miedaner T., Höxter H. \& Geiger H.H. (1993) Development of resistance test for winter rye to snow mold (Microdochium nivale) under controlled environment conditions in regard to field inoculations. Canadian Journal of Botany, 71, 136-144.

Nakajima T. \& Abe J. (1990) A method for assessing resistance to the snow molds Typhula incarnata and Microdochium nivale in winter wheat incubated at the optimum growth temperature ranges of the fungi. Canadian Journal of Botany 68, 343346.

Pronczuk M. \& Zagdanska B. (1993) Effect of Microdochium nivale and low temperature on winter survival of perennial ryegrass. Journal of Phytopathology, 138, 1-8.

Takenaka S. \& Yoshino R. (1989) Development of suitable technique for testing resistance of wheat cultivars to three snow mold diseases. Japan Agricultural Research Quarterly 22, 284-289.

Tronsmo A.M. (1984a) Induced resistance to biotic stress factors in grasses by frost hardening. In Proceedings. Plant Adaptation Workshop: Plant Production in the North. Trolløgda, Tromsø Norway, 4.-10.9.1983. (Ed. by O. Junttila, A. Kaurin \& J. Nilsen) pp. 127-133.

Tronsmo A.M. (1984b) Predisposing effects of low temperature on resistance to winter stress factors in grasses. Acta Agriculturae Scandinavica 34, 210-220.

Tronsmo A.M. (1984c) The effects of hardening, dehardening and freezing on resistance to snow mould fungi in timothy and meadow fescue. In Proceedings of the 10th general meeting of the European Grassland Federation, (Ed. by H. Riley \& A.O. Skjelvåg) pp. 292-296.

Tronsmo A.M. (1985) Effects of dehardening on resistance to freezing and to infection by Typhula ishikariensis in Phleum pratense. Acta Agriculturae Scandinavica 35, 113116.

Tronsmo A.M. (1993) Resistance to winter stress factors in half-sib families of Dactylis glomerata, tested in a controlled environment. Acta Agriculturae Scandinavica Sectio B, Soil and Plant Science 43, 89-96.

Tronsmo A.M., Gregersen P., Hjeljord L., Sandal T., Bryngelsson T. \& Collinge D.B. (1993) Cold-induced disease resistance. In Mechanisms of Plant Defence Responses, (Ed. by B. Fritig \& M. Legrand), pp. 369. Kluwer Academic Publishers, Dordrecht, The Netherlands.

Virtanen A.I. \& Hietala P.K. (1955) 2(3)-Benzoxazolinone, an anti-Fusarium factor in rye seedlings. Acta Chemica Scandinavica 9, 1543-1544. 


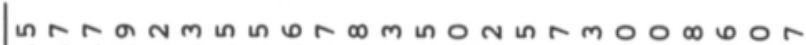
ö ठ ठ

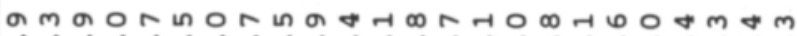

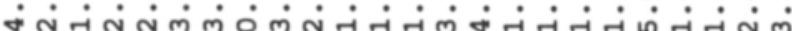

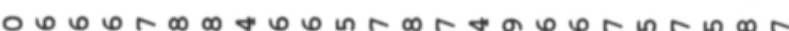

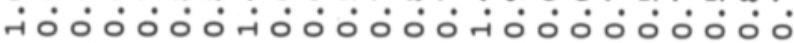

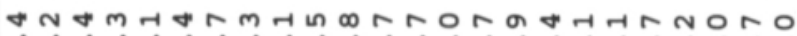

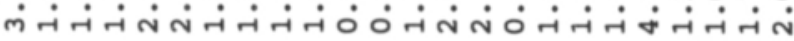
め

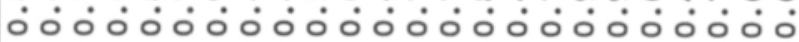
n ó0ं்

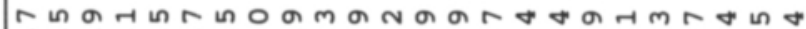
ó ó N $n$ -

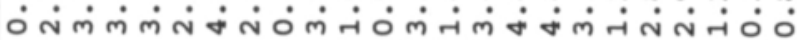

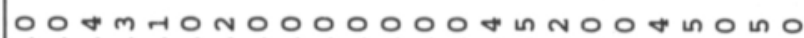
ல் ó

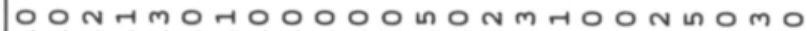
ó

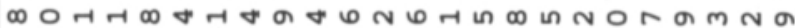
о न न n mm-

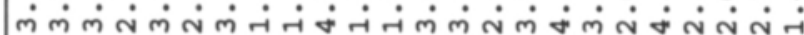

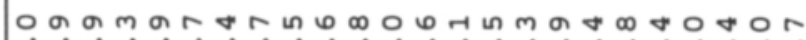

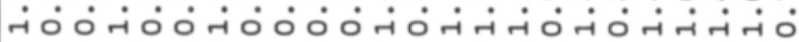

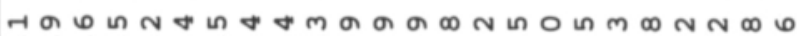

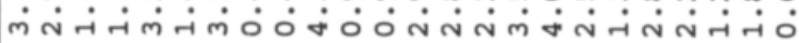

+morat nomno

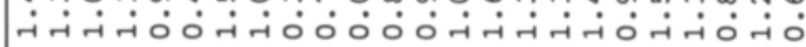
n nंन்َ

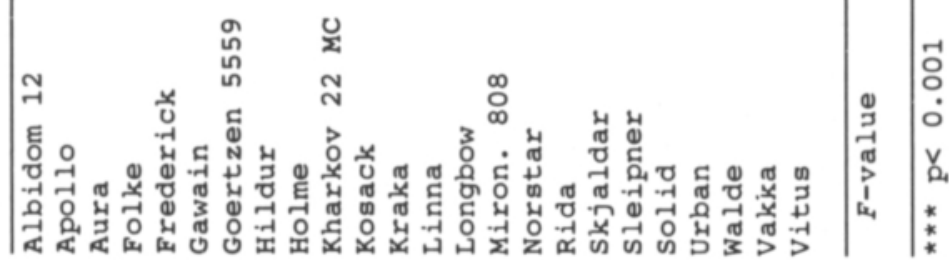




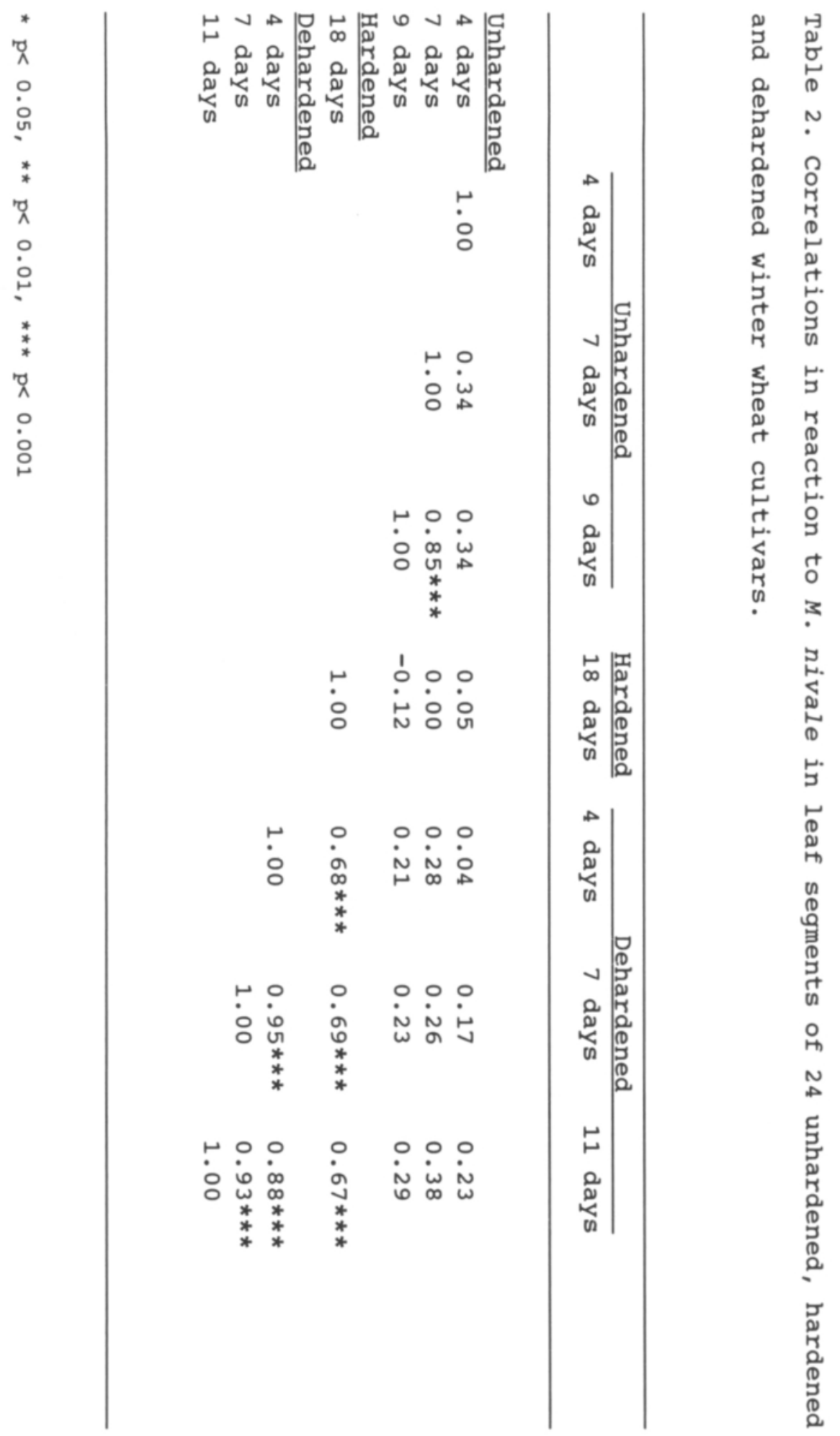


Table 3 . The snow mould resistance of winter wheat cultivars tested in controlled conditions (snow mould chamber) and in the field. The FSI-values are the Field Survival Indexes of the cultivars.

\begin{tabular}{|c|c|c|c|c|c|c|}
\hline Variety & origin & Snow mo & ld chamber & Frost & Field $t$ & cials \\
\hline & & Damage & Survival\% & Resistance & Damage & FSI \\
\hline Albidom 12 & Russia & nd & nd & 84.0 & 2.8 & 91.7 \\
\hline Apollo & Germany & nd & nd & 0.0 & 4.1 & 54.7 \\
\hline Aura & Finland & 1.88 & 94.7 & 84.6 & 2.9 & 87.3 \\
\hline Folke & Sweden & 2.26 & 90.2 & 57.4 & 2.5 & 83.7 \\
\hline Frederick & Canada & nd & nd & 63.2 & 4.6 & 71.4 \\
\hline Gawain & England & nd & nd & 0.0 & 4.7 & 55.6 \\
\hline Goertzen 55 & 559 USA & nd & nd & 72.2 & 3.9 & 69.7 \\
\hline Hildur & Sweden & 2.08 & 87.5 & 71.8 & 3.8 & 70.6 \\
\hline Holme & Sweden & nd & nd & 27.0 & 3.6 & 79.4 \\
\hline Kharkov 22 & MC Ukraina & nd & nd & 60.5 & 3.2 & 83.5 \\
\hline Kosack & Sweden & 2.07 & 97.9 & 24.3 & 2.8 & 85.9 \\
\hline Kraka & Denmark & nd & nd & 9.1 & 3.6 & 76.5 \\
\hline Linna & Finland & 1.90 & 95.7 & 70.3 & 1.9 & 94.5 \\
\hline Longbow & England & nd & nd & 4.2 & 3.8 & 52.4 \\
\hline Miron. 808 & Russia & nd & nd & 0.0 & 3.2 & 83.3 \\
\hline Norstar & Canada & 2.43 & 98.2 & 83.8 & 3.1 & 82.3 \\
\hline Rida & Norway & nd & nd & 64.2 & 3.3 & 83.8 \\
\hline skjaldar & Norway & nd & nd & 53.6 & 2.5 & 85.9 \\
\hline sleipner & Sweden & nd & nd & 33.3 & 1.8 & 69.1 \\
\hline Solid & Sweden & 2.66 & 79.5 & 65.7 & 3.1 & 71.8 \\
\hline Urban & Sweden & nd & nd & 18.9 & 3.5 & 70.7 \\
\hline Vakka & Finland & 1.96 & 96.9 & 67.5 & 2.7 & 91.9 \\
\hline Walde & Sweden & nd & nd & 94.7 & 3.2 & 87.0 \\
\hline vitus & Denmark & nd & nd & 0.0 & nd & nd \\
\hline
\end{tabular}

F-value $5.69 * \star \star \quad 1.10$


Table 4. The statistical significance of the differences in the snow mould resistance among winter wheat cultivars in field trials at five locations during 1991-1992 studied with the analysis of variance. Trials, which were accepted into the calculations of snow mould damage to cultivars in field conditions are indicated as 'included'.

\begin{tabular}{|c|c|c|c|}
\hline Location & Year & F-value & Total damage \\
\hline \multirow[t]{2}{*}{ Jokioinen } & 1990 & $3.47 \star \star \star$ & included \\
\hline & 1991 & $2.10 * *$ & included \\
\hline \multirow[t]{2}{*}{ Mietoinen } & 1990 & $3.05 * \star *$ & included \\
\hline & 1991 & & no snow mould \\
\hline \multirow[t]{2}{*}{ Pälkäne } & 1990 & 1.81 & not included \\
\hline & 1991 & $8.62 \star \star \star *$ & included \\
\hline \multirow[t]{2}{*}{ Laukaa } & 1990 & 1.63 & not included \\
\hline & 1991 & $2.77 \star \star \star$ & included \\
\hline \multirow[t]{2}{*}{ Sotkamo } & 1990 & 0.86 & not included \\
\hline & 1991 & 0.89 & not included \\
\hline
\end{tabular}

DF cultivarg=22 and DF error=69, in other cases but at Pälkäne 1990 DF error $=67$, and at Sotkamo 1990 DF error $=65$

$\star \mathrm{p}<0.05, \star \star \mathrm{p}<0.01, \star \star \star * \mathrm{p}<0.001$ 
Table 5. Correlations among the data from leaf segment tests (unhardened, hardened and dehardened), the snow mould chamber test, the freezing test and field trials (snow mould damage and Field Survival Indexes). $\mathrm{N}=8$ for the snow mould chamber test, 24 for the freezing test, and 23 for the field trials.

$\begin{array}{ccccc}\text { Treatment } & \text { Snow mould chamber } & \begin{array}{c}\text { Freezing } \\ \text { Test }\end{array} & \begin{array}{c}\text { Field } \\ \text { Damage }\end{array} & \text { FSI }\end{array}$

Unhardened

\begin{tabular}{lrlrrr}
\hline 4 days & -0.47 & 0.19 & -0.08 & -0.19 & -0.13 \\
7 days & 0.59 & $-0.81 \star \star$ & 0.05 & 0.04 & -0.08 \\
9 days & 0.55 & $-0.68 *$ & -0.18 & 0.09 & -0.17
\end{tabular}

Hardened

$\begin{array}{llllll}18 \text { days } & 0.40 & -0.10 & 0.28 & 0.10 & -0.06\end{array}$

Dehardened

\begin{tabular}{lrrrrr}
\hline 4 days & 0.48 & -0.07 & $0.40 *$ & -0.02 & 0.18 \\
7 days & 0.43 & 0.05 & 0.31 & -0.07 & 0.02 \\
11 days & 0.52 & -0.22 & 0.33 & 0.07 & -0.02
\end{tabular}

$\begin{array}{llllll}\text { Freezing } & 0.01 & -0.08 & 1.00 & -0.34 & 0.61 \text { * }\end{array}$

Test

$\begin{array}{llllll}\text { Field } & 0.10 & -0.15 & -0.34 & 1.00 & -0.19\end{array}$

Damage

FSI $-0.66 * \quad 0.78 * \quad 0.61 * * \quad-0.19 \quad 1.00$

$\star \mathrm{p}<0.05, \star \star \mathrm{p}^{*}<0.01, \star \star \star \mathrm{p}<0.001$ 